Supporting Information

\title{
A Spiroalkylation Method for the Stereoselective Construction of $\alpha$-Quaternary Carbons and its Application to the Total Synthesis of $(R)$-Puraquinonic Acid
}

Adam A. H. Elmehriki, and James L. Gleason* 


\section{Table of Contents:}

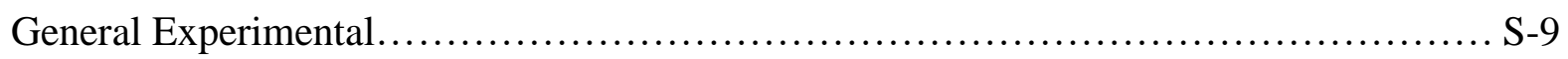

Synthetic Procedures

Lithium 4,4'-Di-tert-butylbiphenylide (LiDBB) .............................. S-9

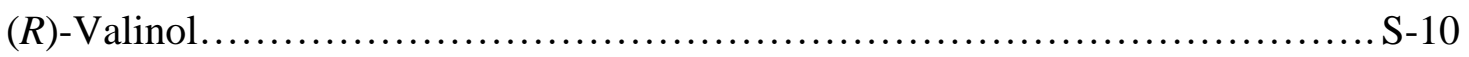

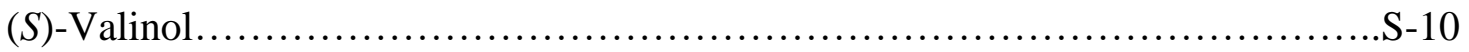

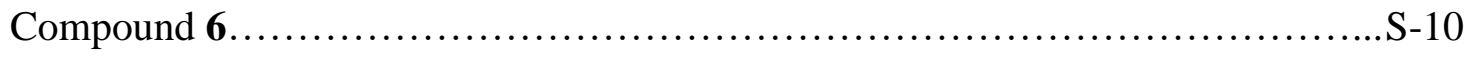

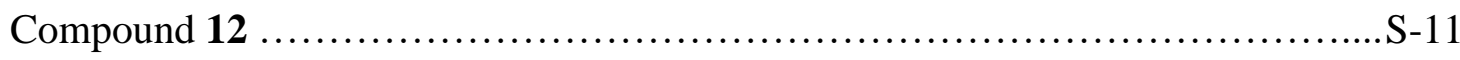

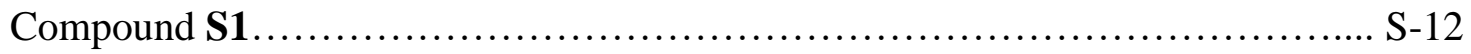

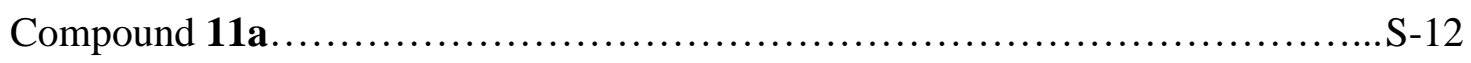

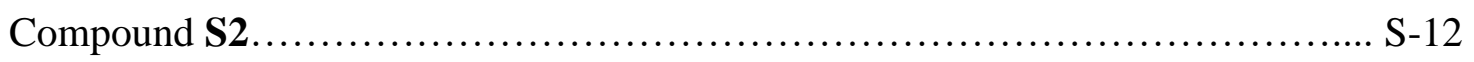

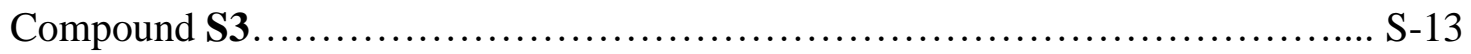

Compound 11b............................................................

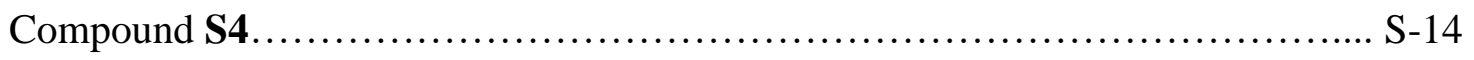

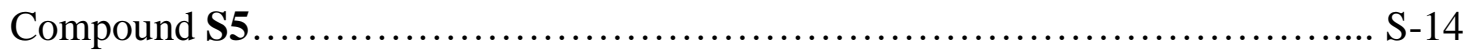

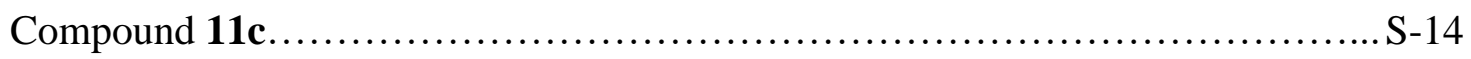

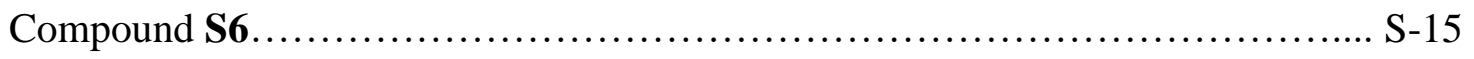

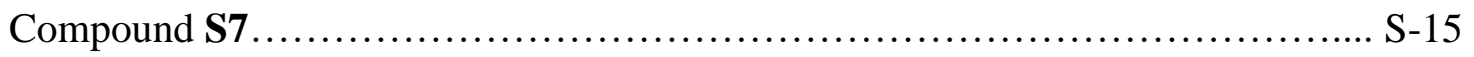

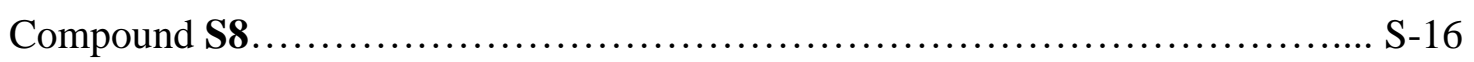

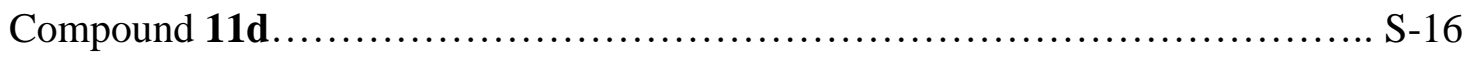

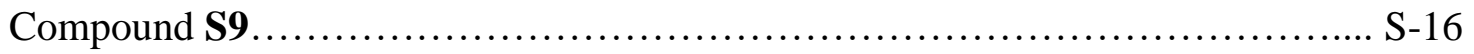

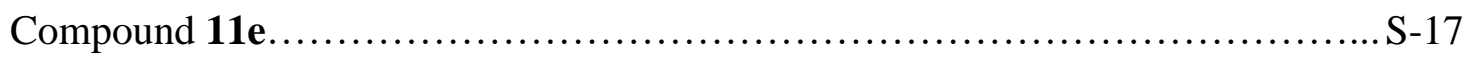

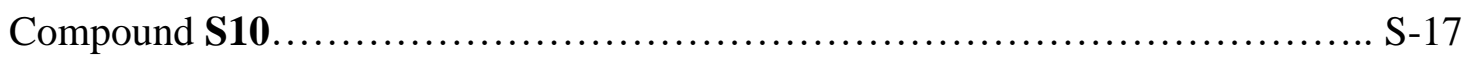

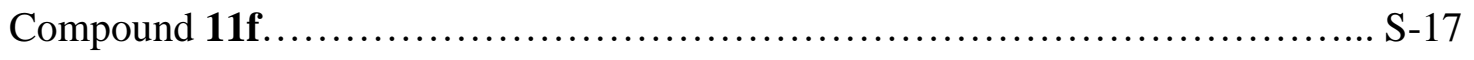

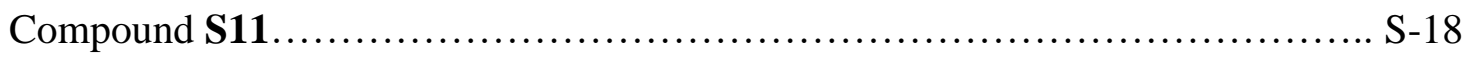

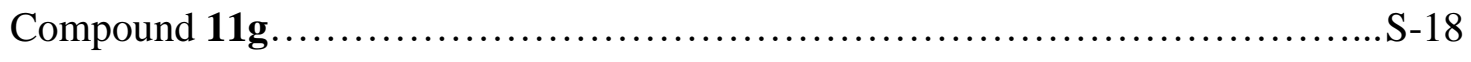

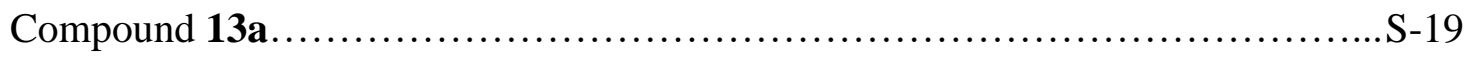

Compound 13b............................................................. 


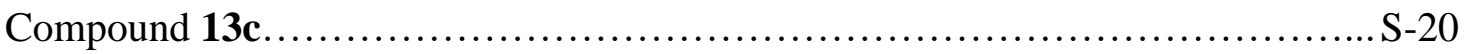

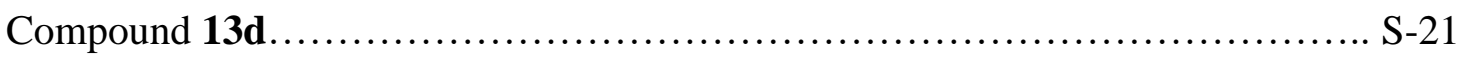

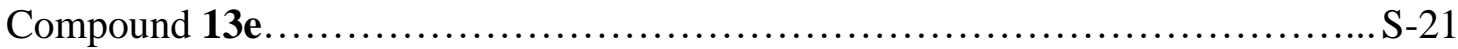

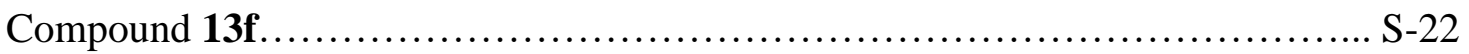

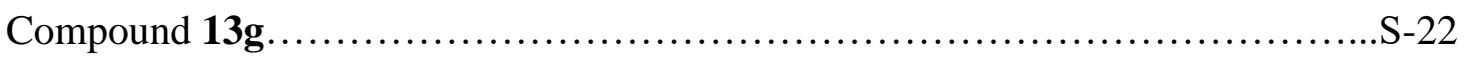

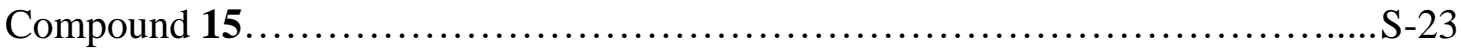

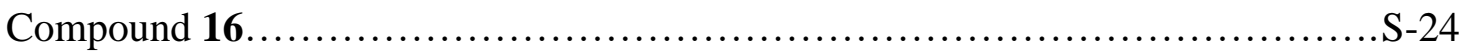

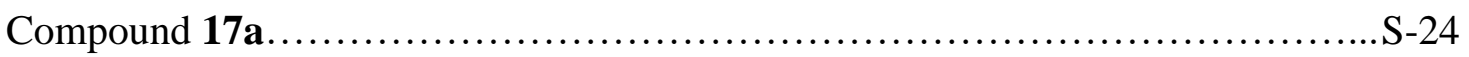

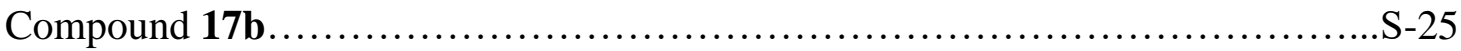

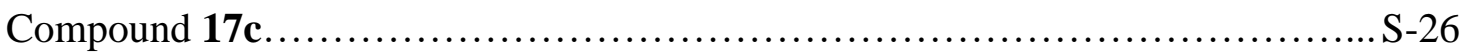

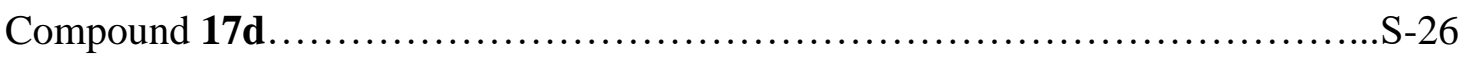

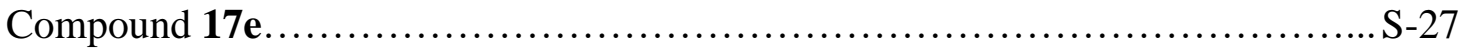

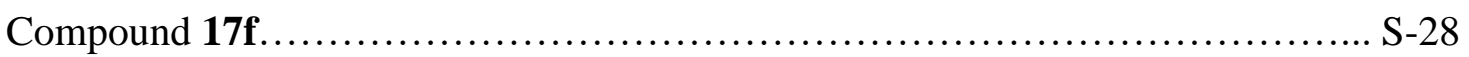

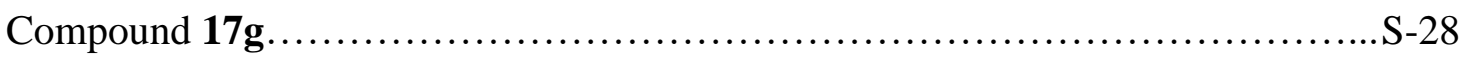

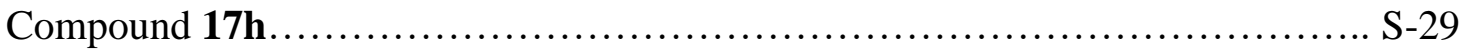

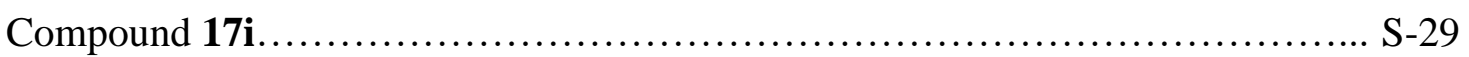

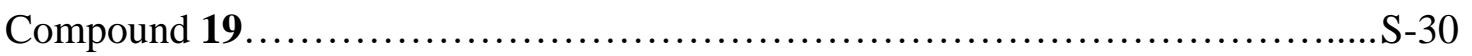

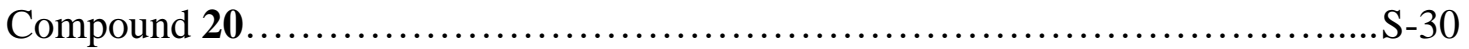

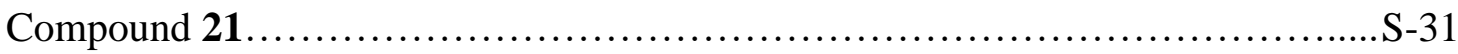

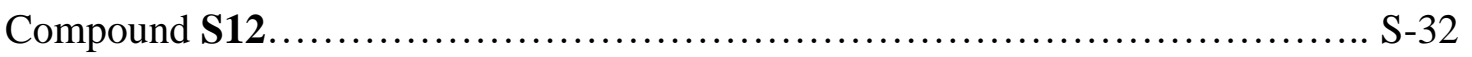

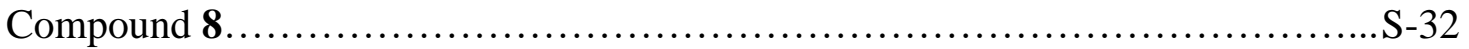

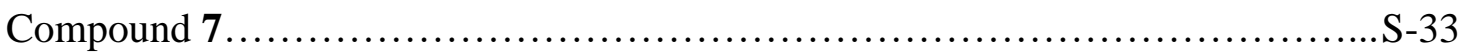

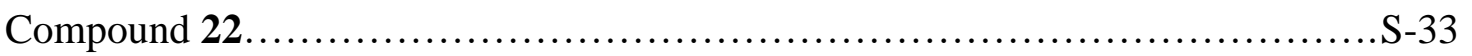

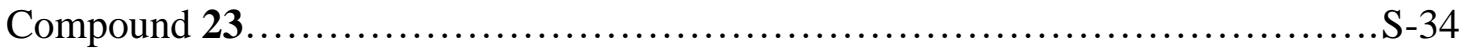

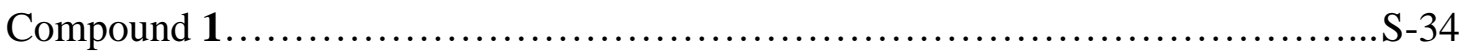

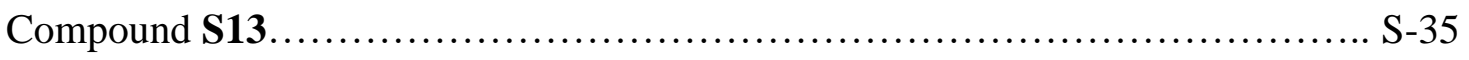

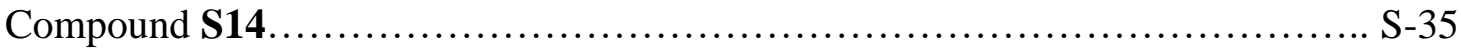

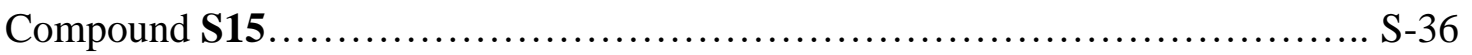




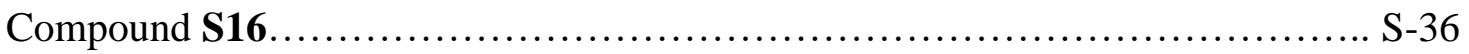

Compound S17 .............................................................. S

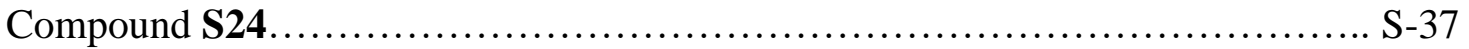

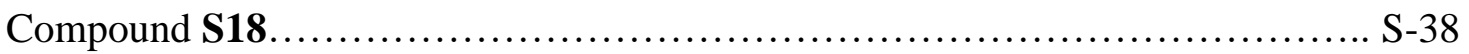

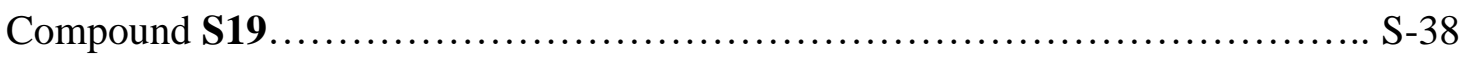

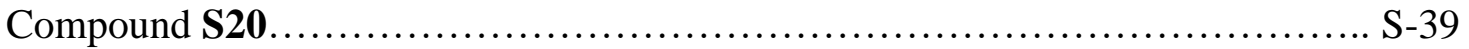

NMR Spectra

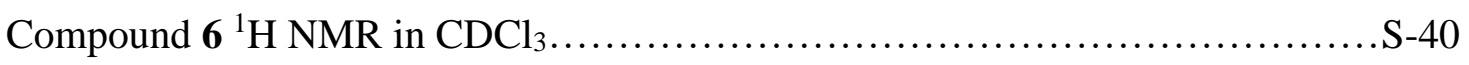

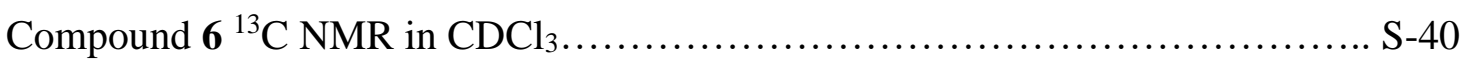

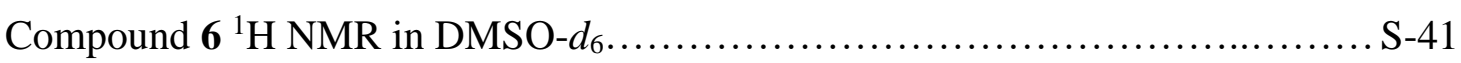

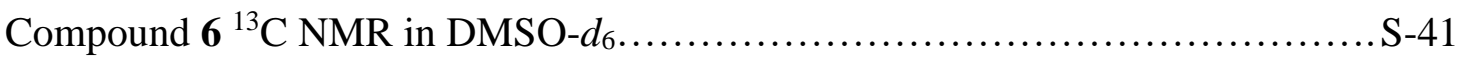

Compound $12{ }^{1} \mathrm{H}$ NMR ......................................................

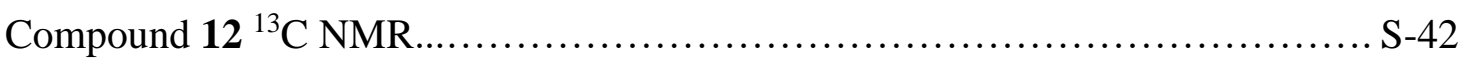

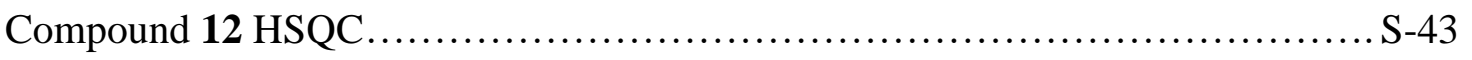

Compound 12 NOESY ..................................................... S-43

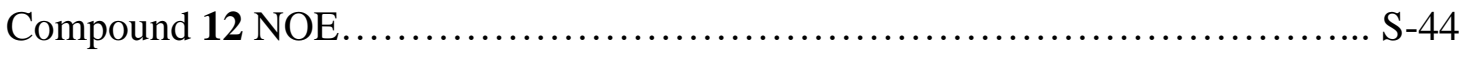

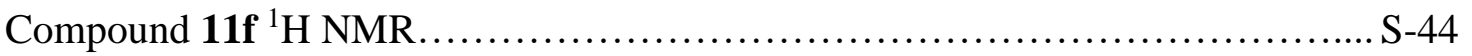

Compound 11f ${ }^{13} \mathrm{C}$ NMR.......................................................... -45

Compound 11g ${ }^{1} \mathrm{H}$ NMR............................................................... S-45

Compound 11g ${ }^{13} \mathrm{C}$ NMR ................................................... S-46

Compound 13a ${ }^{1} \mathrm{H}$ NMR............................................................. S-46

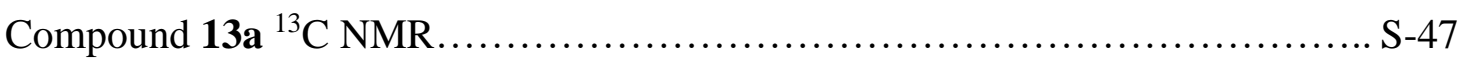

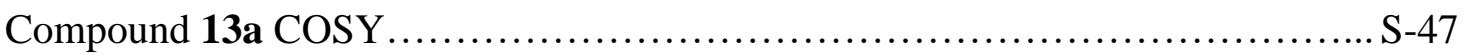

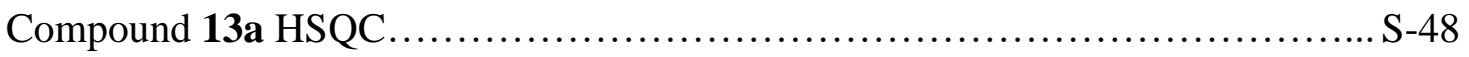

Compound 13a HMBC .................................................... -48

Compound 13a NOESY .................................................... S-49

Compound 13b ${ }^{1} \mathrm{H}$ NMR........................................................ S-49

Compound 13b ${ }^{13} \mathrm{C}$ NMR .................................................... 50 


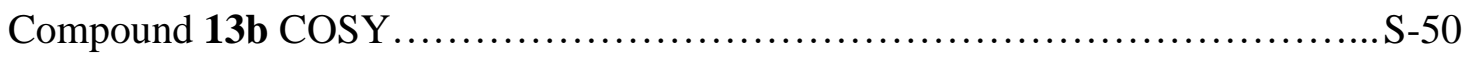

Compound 13b HSQC ............................................................. 51

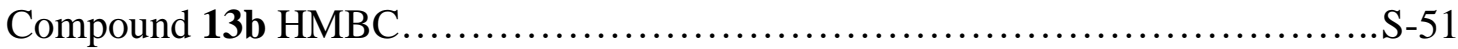

Compound 13b NOESY .....................................................

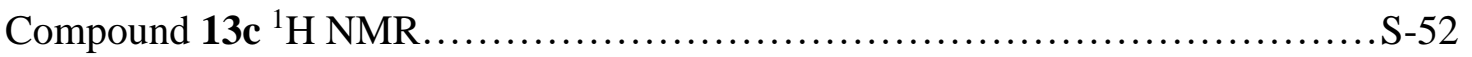

Compound 13c ${ }^{13} \mathrm{C}$ NMR............................................................. S-53

Compound 13c HSQC ......................................................... S-53

Compound 13c HMBC.......................................................... S-54

Compound 13c NOESY ....................................................... 54

Compound 13d ${ }^{1} \mathrm{H}$ NMR ....................................................... S-55

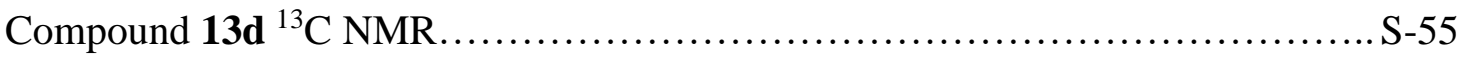

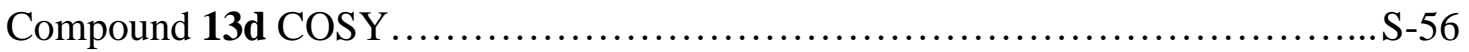

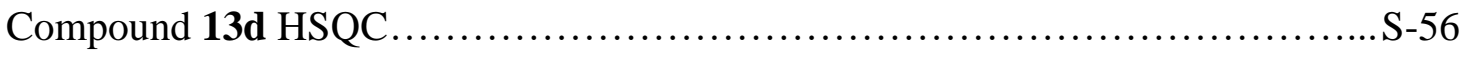

Compound 13d HMBC ...................................................... 57

Compound 13d NOESY .....................................................

Compound 13e ${ }^{1} \mathrm{H}$ NMR............................................................. 58

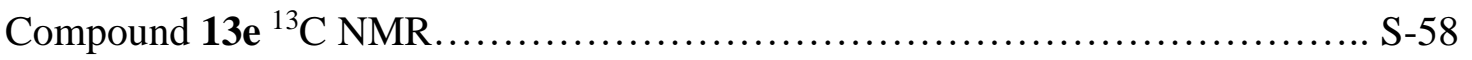

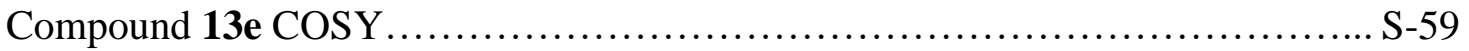

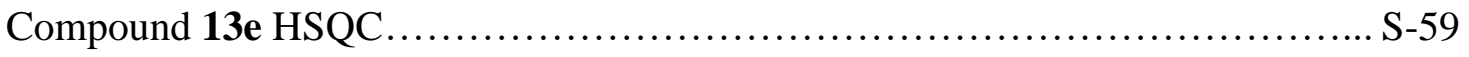

Compound 13e HMBC...................................................... S-60

Compound 13e NOESY ......................................................

Compound $13 f{ }^{1} \mathrm{H}$ NMR ........................................................... S-61

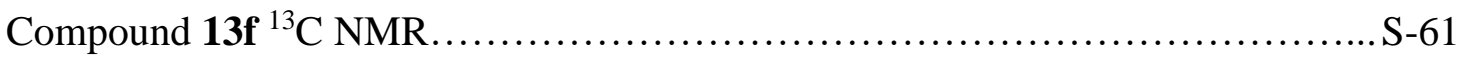

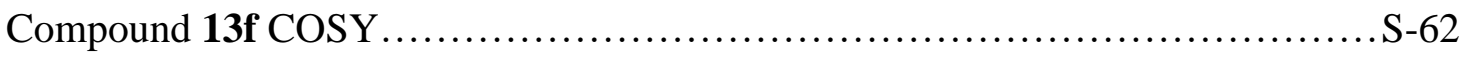

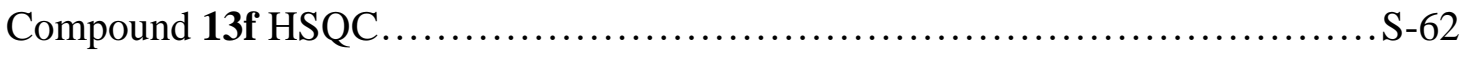

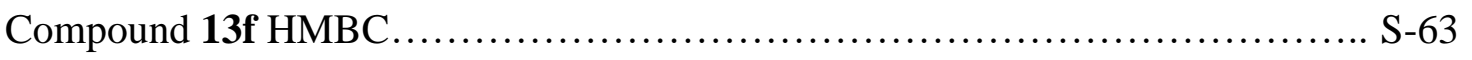

Compound 13f NOESY .......................................................

Compound 13g ${ }^{1} \mathrm{H}$ NMR............................................................ S-64 


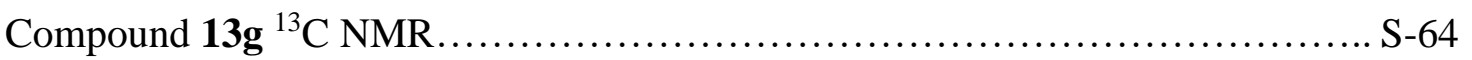

Compound 13g HSQC ........................................................... 65

Compound 13g NOESY .................................................... S-65

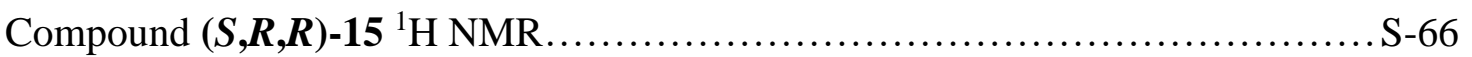

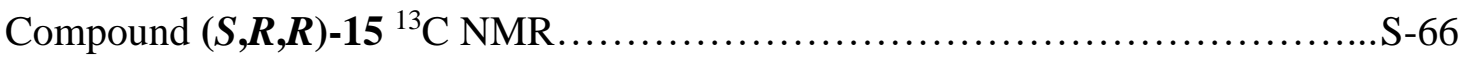

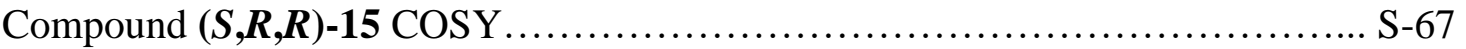

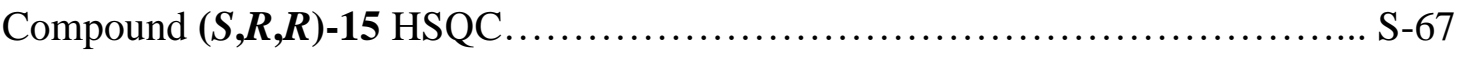

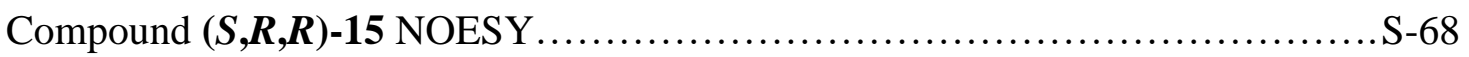

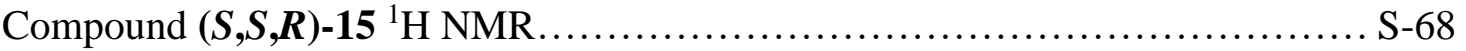

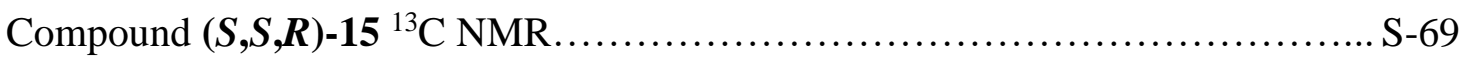

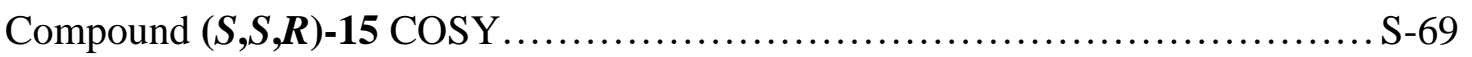

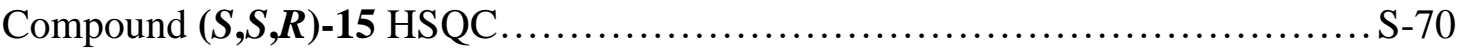

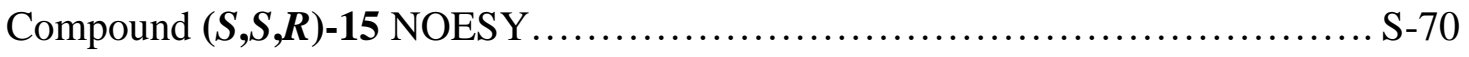

Compound $16{ }^{1} \mathrm{H}$ NMR ......................................................... S-71

Compound $16{ }^{13} \mathrm{C}$ NMR ........................................................

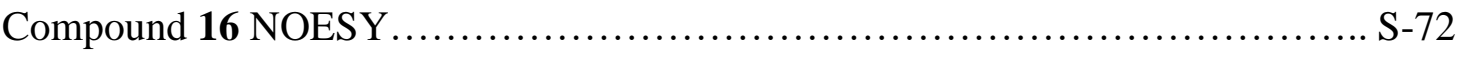

Compound 17a ${ }^{1} \mathrm{H}$ NMR ....................................................... S-72

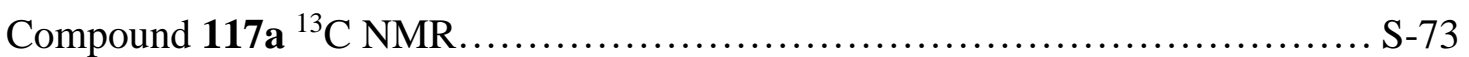

Compound 17b ${ }^{1} \mathrm{H}$ NMR........................................................

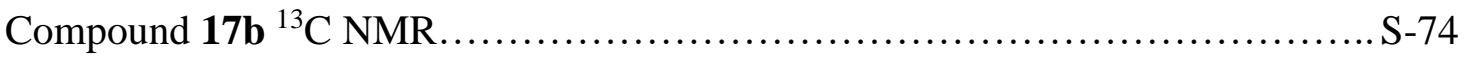

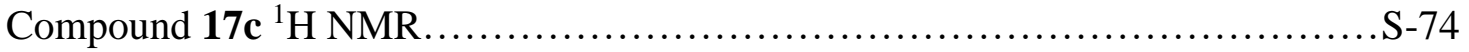

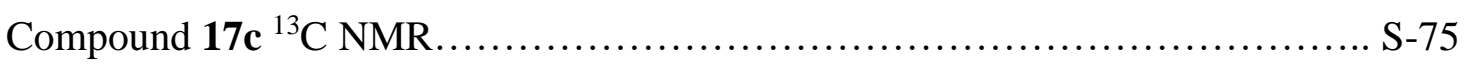

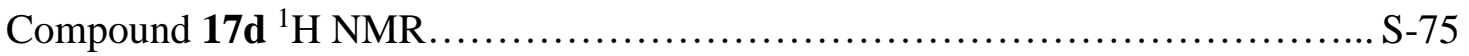

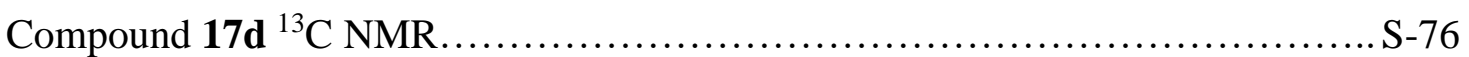

Compound 17e ${ }^{1} \mathrm{H}$ NMR ....................................................

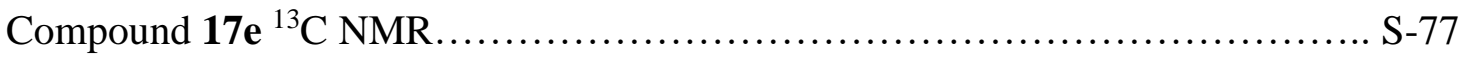

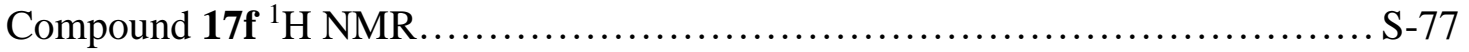

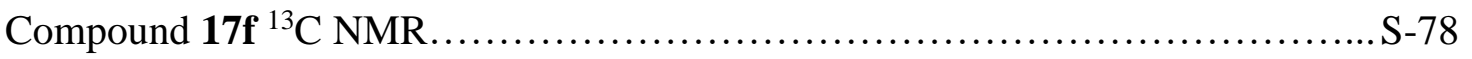


Compound 17g ${ }^{1} \mathrm{H}$ NMR....................................................... S-78

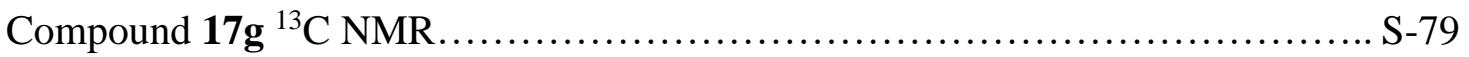

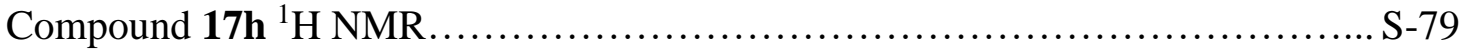

Compound 17h ${ }^{13} \mathrm{C}$ NMR ...................................................

Compound 17i ${ }^{1} \mathrm{H}$ NMR ..................................................... S-80

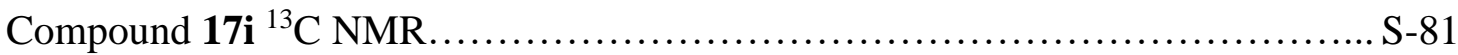

Compound $19{ }^{1} \mathrm{H}$ NMR ...................................................... S-81

Compound $19{ }^{13} \mathrm{C}$ NMR ......................................................

Compound $20{ }^{1} \mathrm{H}$ NMR ....................................................... S-82

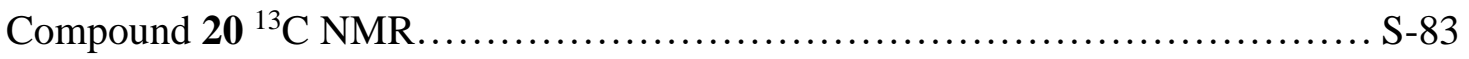

Compound $21{ }^{1} \mathrm{H}$ NMR ..................................................... S-83

Compound $21{ }^{13} \mathrm{C}$ NMR ....................................................

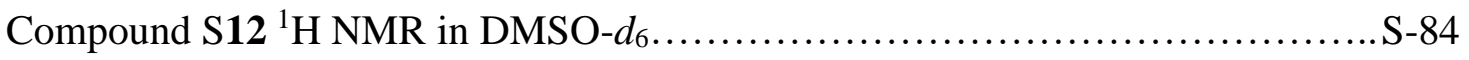

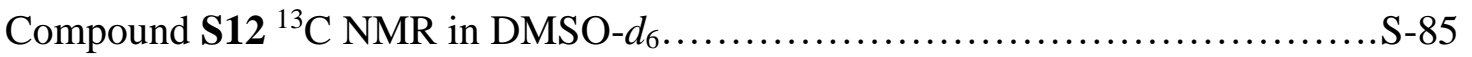

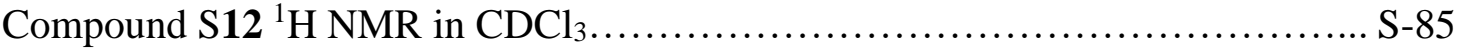

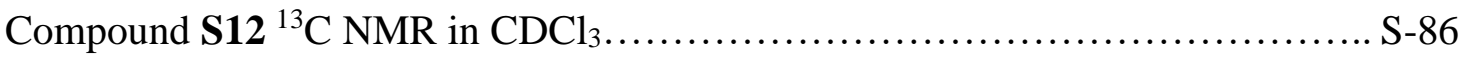

Compound $8{ }^{1}$ H NMR ........................................................... S-86

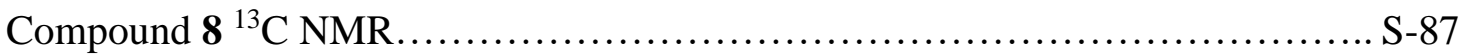

Compound $7{ }^{1} \mathrm{H}$ NMR .......................................................

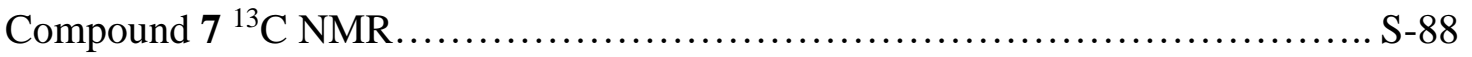

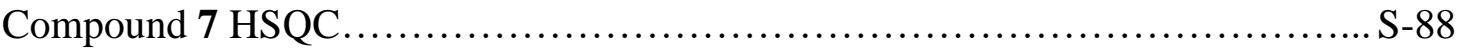

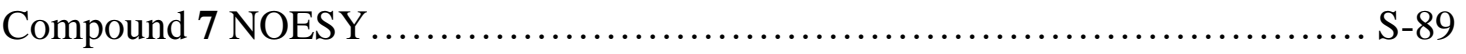

Compound $22{ }^{1} \mathrm{H}$ NMR ....................................................... S-89

Compound $22{ }^{13} \mathrm{C}$ NMR...................................................... S-90

Compound $23{ }^{1} \mathrm{H}$ NMR.................................................. S-90

Compound $23{ }^{13} \mathrm{C}$ NMR ..................................................... S-91

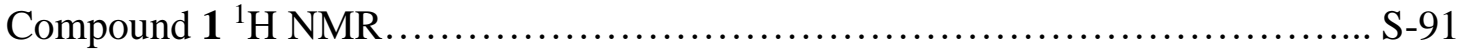

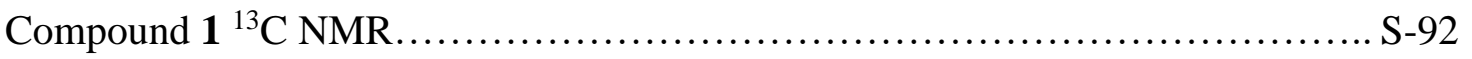


Compound $\mathbf{S 1 3}{ }^{1} \mathrm{H}$ NMR ...................................................

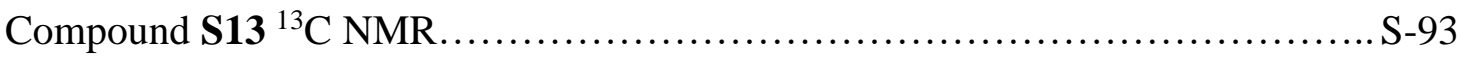

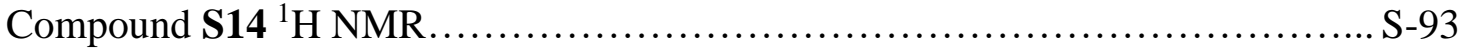

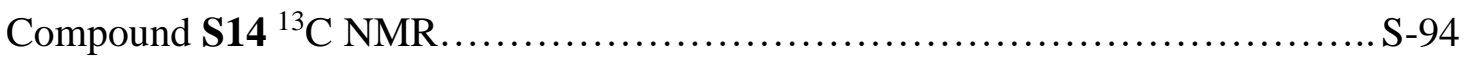

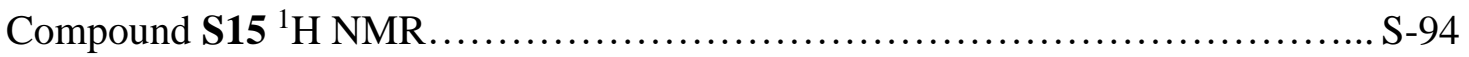

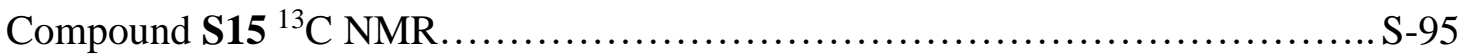

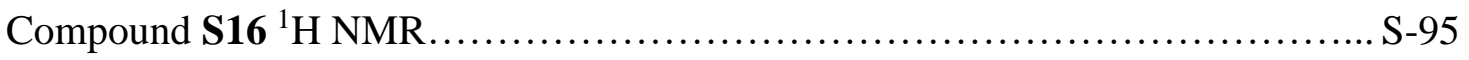

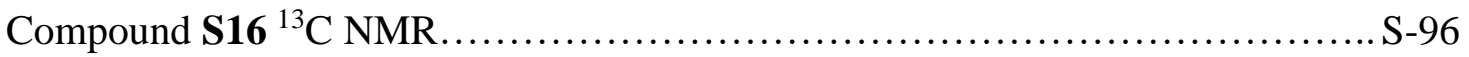

Compound $\mathbf{S 1 7}{ }^{1} \mathrm{H}$ NMR ................................................... S-96

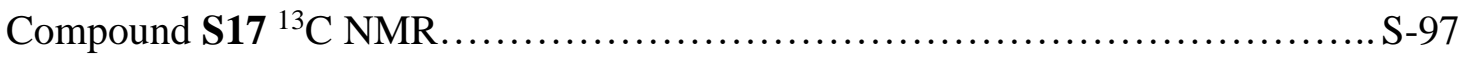

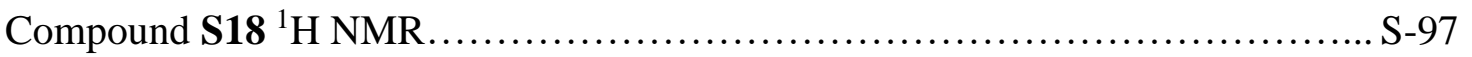

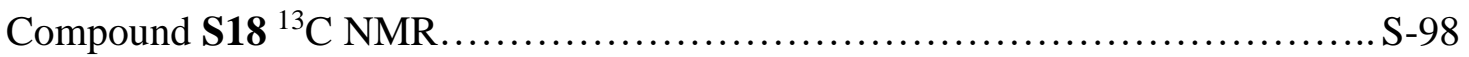

Compound S19 ${ }^{1}$ H NMR.................................................. S-98

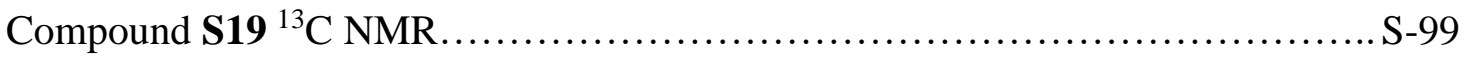

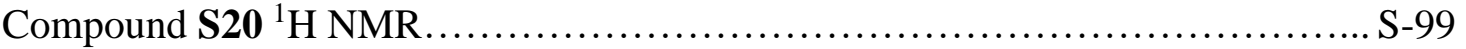

Compound $\mathbf{S 2 0}{ }^{13} \mathrm{C}$ NMR......................................................

Figure 1. Expansion of key regions in the ${ }^{1} \mathrm{H}$ NMR spectra for compounds $\mathbf{2 4}$ and $\mathbf{S 1 6}$ of (126

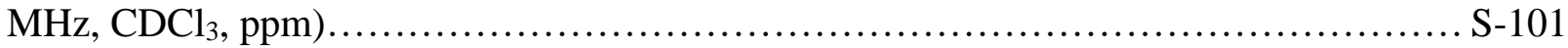

Figure 2. Expansion of key regions in the ${ }^{13} \mathrm{C}$ NMR spectra for compounds $\mathbf{2 4}$ and $\mathbf{S 1 6}$ of (126

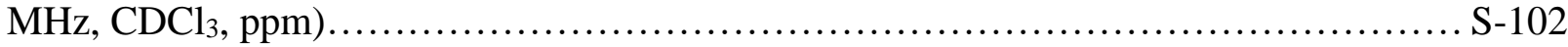

Table 1. Comparison of (R)-puraqunionic acid characterization data......................S-103

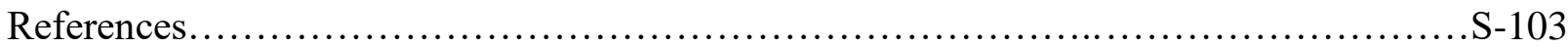




\section{General Experimental}

All reactions were performed using magnetic stirring. Reactions employing dry solvents were conducted using oven or flame-dried round bottom flasks. Reactions requiring controlled atmospheres were fitted with rubber septa unless otherwise stated. Oil baths were used for reactions performed at temperatures in excess of room temperature. The cooling of reactions below room temperature was accomplished using one of the following techniques: ice/water bath $\left(0{ }^{\circ} \mathrm{C}\right)$, dry ice/acetone bath $\left(-78{ }^{\circ} \mathrm{C}\right)$, or by placement in an ${ }^{i} \mathrm{PrOH}$ bath within a cryostat (variable temperature). Liquids and solutions were transferred via syringe or stainless-steel cannula under inert conditions. Thin-layer chromatography (TLC) was carried out on glass plates, coated with $250 \mu \mathrm{m}$ of 230 - 400 mesh silica gel that had been saturated with F-254 indicator. TLC plates were visualised using ultraviolet light and/or by exposure to an acidic solution of cerium (IV) ammonium molybdate followed by heating, a basic solution of potassium permanganate followed by heating, an acidic solution of $p$-anisaldehyde followed by heating, or exposure to $\mathrm{I}_{2}$ vapours. Flash column chromatography was carried out utilising $230-400$ mesh silica gel (Silicycle) with reagent grade solvents. In some instances, a CombiFlash Rf automated column system was employed. In such cases the solvent gradient and flow rate are indicated. Room temperature (r.t.) indicates a temperature of $22{ }^{\circ} \mathrm{C}$. All commercial reagents were used without further purification with the following exceptions: tetrahydrofuran (THF) and diethyl ether $\left(\mathrm{Et}_{2} \mathrm{O}\right)$ were distilled from sodium/benzophenone ketyl radical under an atmosphere of nitrogen; dichloromethane ( $\mathrm{DCM})$, toluene $(\mathrm{PhMe})$, triethylamine, and diisopropylamine were distilled from calcium hydride under a dry air atmosphere; or unless otherwise stated. Alkyl halides were purified immediately prior to use by passing neat through activated, basic, Brockmann I aluminum oxide. Infrared (IR) spectra were obtained using a Perkin-Elmer Spectrum One FT-IR spectrophotometer. NMR spectra were recorded on a $500 \mathrm{MHz}$ Varian or 400, $500 \mathrm{MHz}$ Bruker spectrometers. Chemical shifts $(\delta)$ were internally referenced to the residual solvent resonance; $\mathrm{CDCl}_{3}(\delta \mathrm{H} 7.26 \mathrm{ppm}, \delta \mathrm{C} 77.0 \mathrm{ppm})$ and DMSO- $d_{6}(\delta \mathrm{H} 2.50 \mathrm{ppm}, \delta \mathrm{C}$ $39.5 \mathrm{ppm})$. The following abbreviations were used to describe NMR signal multiplicities: singlet $(\mathrm{s})$, doublet $(\mathrm{d})$, triplet $(\mathrm{t})$, quartet $(\mathrm{q})$, and multiplet $(\mathrm{m})$. Coupling constants $(J)$ are reported in Hertz $(\mathrm{Hz})$. Optical rotations were measured on a JAS.CO DIP-40 digital polarimeter using a Na lamp (589 nm). High resolution mass spectrometry (HRMS) was conducted by Dr. Alexander Wahba or Dr. Nadim Saadé in the Mass Spectrometry Facility in the Department of Chemistry, McGill University. High resolution, accurate mass measurements were made using the a Thermo Exactive Plus Orbitrap-API or Bruker Maxis API QqTOF mass spectrometer. Low resolution mass spectrometry (LRMS) were measured on a Thermo Polaris Q CI quadrupole in trap mass spectrometer.

Lithium 4,4'-Di-tert-butylbiphenylide (LiDBB): LiDBB was prepared from a procedure described by Hill and Rychnovsky. ${ }^{[1]}$ 4,4'-Di-tert-butylbiphenyl was purified via recrystallisation from hot $\mathrm{Et}_{2} \mathrm{O}$ and dried under high vacuum prior to use. Following purification 4,4'-Di-tertbutylbiphenyl (1.50 g, $5.63 \mathrm{mmol}, 1$ equiv) was placed in a dry flask equipped with a stir bar and fused under vacuum. Once cooled to r.t. 4,4'-Di-tert-butylbiphenyl was dissolved in THF (14 ml, dry and degassed freeze-pump-thaw, three cycles) $\mathrm{Li}^{\circ}$ (390 mg, $56.4 \mathrm{mmol}, 10$ equiv) was pressed into thin sheets then rinsed with hexanes, $\mathrm{MeOH}$, hexanes, and finally THF, then quickly added to the solution of 4,4'-Di-tert-butylbiphenyl under a stream of argon. The reaction was cooled to $0{ }^{\circ} \mathrm{C}$ and left to stir for 5 hours under an atmosphere of argon. Excess reagent was stored at $0{ }^{\circ} \mathrm{C}$, under an argon atmosphere for up to one week. 


\section{(R)-Valinol:}

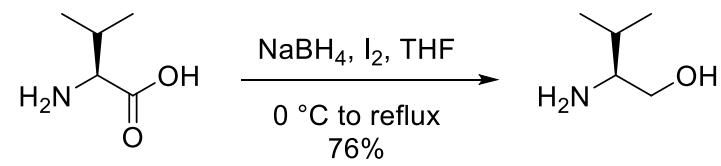

A solution of iodine $(50.8 \mathrm{~g}, 200 \mathrm{mmol}, 1$ equiv) in dry THF (140 ml) was added drop-wise to a solution of L-valine (23.4 g, $200 \mathrm{mmol}, 1$ equiv) and $\mathrm{NaBH}_{4}$ (18.2 g, $480 \mathrm{mmol}, 2.4$ equiv) in dry THF $(500 \mathrm{ml})$ over the course of 1 hour at $0{ }^{\circ} \mathrm{C}$ under an atmosphere of argon. Once the addition was complete the flask was then equipped with a reflux condenser then heated to reflux and left to stir overnight. The reaction was then cooled to r.t. and quenched with $\mathrm{MeOH}$ until effervescence ceased then concentrated by rotary evaporation to afford a white paste which was dissolved in $25 \% \mathrm{KOH}_{(\mathrm{aq})}(400 \mathrm{ml})$, left to stir for 4 hours at r.t. then extracted with DCM $(3 \times$ $400 \mathrm{ml}$ ). Combined organic extracts were then dried over $\mathrm{Na}_{2} \mathrm{SO}_{4}$, filtered, and concentrated to afford a clear colourless liquid. The liquid was purified via distillation $\left(4 \mathrm{mmHg}, 58-61{ }^{\circ} \mathrm{C}\right)$ to afford $(R)$-valinol as a clear colourless viscous liquid $(15.64 \mathrm{~g}, 76 \%)$ which solidified to give a white solid upon cooling. The solid gave off an odour reminiscent of corn chips or hay. Spectra agreed with previous reports. ${ }^{[2]}{ }^{1} \mathbf{H}$ NMR $\left(500 \mathrm{MHz}, \mathrm{CDCl}_{3}\right) \delta \mathrm{H} 3.63(1 \mathrm{H}, \mathrm{dd}, J=10.4,3.64$ Hz), 3.26 (1H, dd, $J=10.3,10.0 \mathrm{~Hz}), 2.75$ (1H, br. s, $\mathrm{D}_{2} \mathrm{O}$ exch.), 2.54 (1H, ddd, $J=9.0,6.5,4.1$ $\mathrm{Hz}), 1.55(1 \mathrm{H}, \mathrm{qqd}, J=6.9,6.9,6.9 \mathrm{~Hz}), 1.11\left(2 \mathrm{H}\right.$, br. s, $\mathrm{D}_{2} \mathrm{O}$ exch. $), 0.93(3 \mathrm{H}, \mathrm{d}, J=7.4 \mathrm{~Hz})$, $0.91(3 \mathrm{H}, \mathrm{d}, J=7.1 \mathrm{~Hz}) .{ }^{13} \mathrm{C}$ NMR $\left(126 \mathrm{MHz}, \mathrm{CDCl}_{3}\right) \delta \mathrm{C} 63.0,58.7,30.3,19.0,18.7$.

\section{(S)-Valinol:}

$(S)$-valinol was prepared in the same fashion as described for $(R)$-valinol, from D-valine $(5.86 \mathrm{~g}$, $50.0 \mathrm{mmol}, 1$ equiv), iodine (12.7 g, $50 \mathrm{mmol}, 1$ equiv), and $\mathrm{NaBH}_{4}$ (4.54 g, $120 \mathrm{mmol}, 2.4$ equiv) in THF $(160 \mathrm{ml})$. Purification via distillation $\left(4 \mathrm{mmHg}, 58-61{ }^{\circ} \mathrm{C}\right)$ to afford $(S)$-valinol as a clear colourless viscous liquid $(3.60 \mathrm{~g}, 70 \%)$ that has a more pronounced amine odour than $(R)$-valinol and is reminiscent of the smell found within a barn. ${ }^{1} \mathbf{H} \mathbf{N M R}\left(500 \mathrm{MHz}, \mathrm{CDCl}_{3}\right) \delta \mathrm{H}$ $3.61(1 \mathrm{H}, \mathrm{dd}, J=10.4,3.64 \mathrm{~Hz}), 3.26(1 \mathrm{H}, \mathrm{dd}, J=10.3,10.0 \mathrm{~Hz}), 2.61\left(1 \mathrm{H}\right.$, br. s, $\mathrm{D}_{2} \mathrm{O}$ exch.), $2.55(1 \mathrm{H}$, ddd, $J=9.0,6.5,4.1 \mathrm{~Hz}), 1.55(1 \mathrm{H}, \mathrm{qqd}, J=6.9,6.9,6.9 \mathrm{~Hz}), 1.26\left(2 \mathrm{H}\right.$, br. s, $\mathrm{D}_{2} \mathrm{O}$ exch.), $0.93(3 \mathrm{H}, \mathrm{d}, J=7.4 \mathrm{~Hz}), 0.91(3 \mathrm{H}, \mathrm{d}, J=7.1 \mathrm{~Hz}) .{ }^{13} \mathbf{C}$ NMR (126 MHz, CDCl 3 ) $\delta \mathrm{C} 63.0$, $58.7,30.3,19.0,18.7$.

\section{7,7-Dioxide (3S,9aR)-3-isopropyltetrahydro-8H-oxazolo[3,2-d][1,4]thiazepin-5(6H)-one (6):}

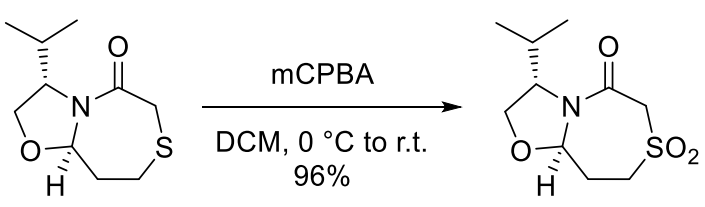

mCPBA (77\% wt $\%, 11.45 \mathrm{~g}, 51.09 \mathrm{mmol}, 2.2$ equiv) was added in small portions to a solution of lactam $\mathbf{5}^{[3]}\left(5.00 \mathrm{~g}, 23.2 \mathrm{mmol}, 1\right.$ equiv) in DCM $(150 \mathrm{ml})$ at $0{ }^{\circ} \mathrm{C}$. To this was added and the reaction stirred at r.t. overnight. Sat. $\mathrm{NHCO}_{3}(150 \mathrm{ml})$ was then added to the reaction and phases separated. The aqueous phase was extracted with DCM $(2 \times 150 \mathrm{ml})$. Combined organic extracts were dried over $\mathrm{Na}_{2} \mathrm{SO}_{4}$, filtered, and concentrated to afford a white solid. The solid was triturated with $\mathrm{Et}_{2} \mathrm{O}$ and provided sulfone $\mathbf{6}$ as a white solid upon filtration $(5.51 \mathrm{~g}, 96 \%)$. ${ }^{1} \mathbf{H}$ NMR $\left(500 \mathrm{MHz}, \mathrm{CDCl}_{3}\right) \delta \mathrm{H} 5.45(1 \mathrm{H}, \mathrm{d}, J=9.0 \mathrm{~Hz}), 4.27,(1 \mathrm{H}, \mathrm{d}, J=15.0 \mathrm{~Hz}), 4.25(1 \mathrm{H}, \mathrm{m})$, $3.89(3 \mathrm{H}, \mathrm{m}), 3.39(1 \mathrm{H}, \mathrm{m}), 3.35(1 \mathrm{H}, \mathrm{m}), 2.57(1 \mathrm{H}, \mathrm{m}), 2.46(1 \mathrm{H}, \mathrm{m}), 2.33(1 \mathrm{H}, \mathrm{m}), 0.91(3 \mathrm{H}, \mathrm{d}$, 
$J=7.1 \mathrm{~Hz}), 0.82(3 \mathrm{H}, \mathrm{d}, J=7.0) ;{ }^{1} \mathbf{H}$ NMR $\left(500 \mathrm{MHz}, \mathrm{DMSO}-d_{6}\right) \delta \mathrm{H} 5.71(1 \mathrm{H}, \mathrm{d}, J=9.4 \mathrm{~Hz})$, $5.09(1 \mathrm{H}, \mathrm{d}, J=14.8 \mathrm{~Hz}), 4.01(1 \mathrm{H}, \mathrm{m}), 3.97(1 \mathrm{H}, \mathrm{m}), 3.78(1 \mathrm{H}, \mathrm{dd}, J=14.8,4.1 \mathrm{~Hz}), 3.69(1 \mathrm{H}$, $\mathrm{dd}, J=13.2,3.2 \mathrm{~Hz}), 3.37(1 \mathrm{H}, \mathrm{m}), 2.24-2.36(2 \mathrm{H}, \mathrm{m}), 2.12(1 \mathrm{H}, \mathrm{dt}, J=14.3,4.1 \mathrm{~Hz}), 0.83$ $(3 \mathrm{H}, \mathrm{d}, J=7.0 \mathrm{~Hz}), 0.74(3 \mathrm{H}, \mathrm{d}, J=7.0 \mathrm{~Hz}) ;{ }^{13} \mathbf{C ~ N M R}\left(126 \mathrm{MHz}, \mathrm{CDCl}_{3}\right) \delta \mathrm{C} 157.2,88.7,65.6$, 62.1, 61.2, 53.0, 32.0, 27.5, 19.2, 15.8; ${ }^{13} \mathrm{C}$ NMR (126 MHz, DMSO-d6) $\delta \mathrm{C} 157.8,87.6,64.7$, 61.0, 60.8, 52.2, 31.9, 27.1, 18.9, 15.6; HRMS (ESI/QqTOF) $\mathbf{m} / \mathbf{z}$ : $[\mathrm{M}+\mathrm{Na}]^{+}$calculated for $\left[\mathrm{C}_{10} \mathrm{H}_{17} \mathrm{NO}_{4} \mathrm{SNa}\right]^{+} 270.0770$, found 270.0764; IR (neat) $\tilde{v}=2992,2962,2932,2893,2869,1661$, $1487,1463,1438,1420,1392,1372,1337,1313,1295,1239,1225,1192,1169,1158,1115$, $1110,1092,1036,1007,977,967,954,853,826,790,759,709,686 \mathrm{~cm}^{-1} ;[\boldsymbol{\alpha}]_{\mathbf{D}}^{\mathbf{2 2}}-74.6(c 0.5$, 9:1 MeOH/DMSO); $\mathbf{M p ~ 2 6 1 - 2 6 3 ~}{ }^{\circ} \mathrm{C}$.

(3S,3'S,6S,6'S,9aR,9a'R)-6,6'-((3-methoxy-1,2-phenylene)bis(methylene))bis(3-isopropyl tetrahydro-8H-oxazolo[3,2-d][1,4]thiazepin-5(6H)-one) (12):

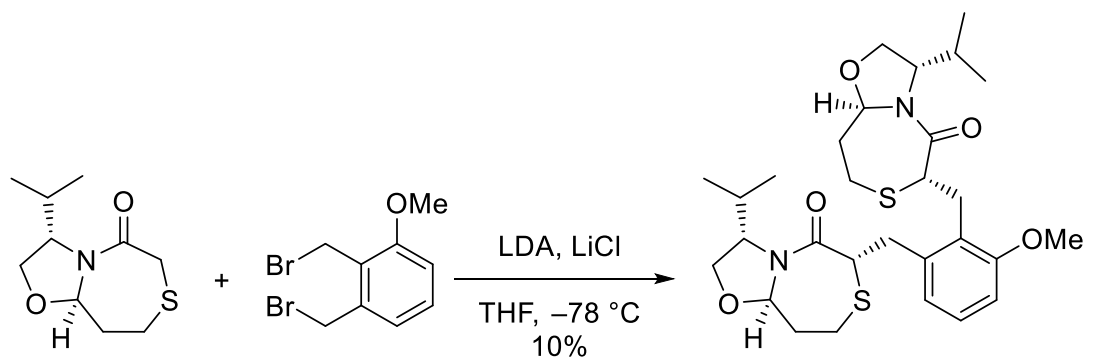

$n \operatorname{BuLi}(0.23 \mathrm{ml}, 0.55 \mathrm{mmol}, 1.1$ equiv) was added to a solution of diisopropylamine $(0.80 \mathrm{ml}$, $0.58 \mathrm{mmol}, 1.15$ equiv) and flame dried lithium chloride (106 mg, $2.5 \mathrm{mmol}, 5.0$ equiv) in dry THF $(5 \mathrm{ml})$ at $-78{ }^{\circ} \mathrm{C}$ under an atmosphere of argon. After stirring at $-78{ }^{\circ} \mathrm{C}$ for $15 \mathrm{~min}$, lactam 5 (108 $\mathrm{mg}, 0.50 \mathrm{mmol}, 1$ equiv) was added drop-wise as a solution dry THF $(2.5 \mathrm{ml})$. The reaction was stirred at $-78{ }^{\circ} \mathrm{C}$ for $20 \mathrm{~min}$ before dibromide $11 a$ (294 mg, $1.0 \mathrm{mmol}, 2.0$ equiv) was added drop-wise as a solution in dry THF $(2.5 \mathrm{ml})$. The reaction was then left to stir at -78 ${ }^{\circ} \mathrm{C}$ for $4 \mathrm{~h}$. At this time the reaction was quenched with sat $\mathrm{NH}_{4} \mathrm{Cl}_{(\mathrm{aq})}(10 \mathrm{ml})$ and then extracted with EtOAc $(2 \times 15 \mathrm{ml})$. Combined organic extracts were dried over $\mathrm{Na}_{2} \mathrm{SO}_{4}$ and concentrated to afford a yellow solid which was purified by column chromatography (15 $\mathrm{g} \mathrm{SiO}_{2}, 0-40 \%$ EtOAc in hexanes) affording arene $\mathbf{1 2}$ was as a white solid $(28 \mathrm{mg}, 10 \%)$. ${ }^{1} \mathbf{H}$ NMR $(500 \mathrm{MHz}$, $\left.\mathrm{CDCl}_{3}\right) \delta \mathrm{H} 7.16(1 \mathrm{H}, \mathrm{t}, J=7.9 \mathrm{~Hz}), 6.89(1 \mathrm{H}, \mathrm{d}, J=7.8 \mathrm{~Hz}), 6.77(1 \mathrm{H}, \mathrm{d}, J=7.9 \mathrm{~Hz}), 5.48(1 \mathrm{H}$, $\mathrm{d}, J=6.9 \mathrm{~Hz}), 5.46(1 \mathrm{H}, \mathrm{d}, J=6.6 \mathrm{~Hz}), 4.29(2 \mathrm{H}, \mathrm{m}), 3.92-3.97(2 \mathrm{H}, \mathrm{m}), 3.75-3.87(4 \mathrm{H}, \mathrm{m})$, $3.81(3 \mathrm{H}, \mathrm{s}), 3.63(1 \mathrm{H}, \mathrm{dd},, J=14.8,6.0 \mathrm{~Hz}), 3.56(1 \mathrm{H}, \mathrm{dd}, 14.3,4.6 \mathrm{~Hz}), 3.15(1 \mathrm{H}, \mathrm{dd}, 14.2,9.3$ $\mathrm{Hz}), 3.02(1 \mathrm{H}, \mathrm{m}), 2.88(1 \mathrm{H}, \mathrm{m}), 2.72(1 \mathrm{H}, \mathrm{dt}, 14.2,4.6 \mathrm{~Hz}), 2.65(1 \mathrm{H}, \mathrm{dt}, 14.3,4.3 \mathrm{~Hz}), 2.30-$ $2.44(4 \mathrm{H}, \mathrm{m}), 2.06(2 \mathrm{H}, \mathrm{m}), 0.88(6 \mathrm{H}, \mathrm{d}, 6.7 \mathrm{~Hz}), 0.56(3 \mathrm{H}, \mathrm{d}, 7.0 \mathrm{~Hz}), 0.84(3 \mathrm{H}, \mathrm{d}, 6.9 \mathrm{~Hz}) ;{ }^{13} \mathrm{C}$ NMR $\left(126 \mathrm{MHz}, \mathrm{CDCl}_{3}\right) \delta \mathrm{C} 170.1,169.6,158.0,138.3,127.4,126.1,122.2,109.1,88.8,88.7$, 64.5, 64.2, 62.4, 62.2, 55.4, 48.6, 47.9, 34.7, 34.4, 33.8, 28.0, 27.7, 26.8, 24.4, 24.3, 19.1, 19.1, 16.1, 15.9; HRMS (ESI/QqTOF) m/z: $[\mathrm{M}+\mathrm{Na}]^{+}$calculated for $\left[\mathrm{C}_{29} \mathrm{H}_{42} \mathrm{O}_{5} \mathrm{~N}_{2} \mathrm{NaS}_{2}\right]^{+} 585.2437$, found 585.2438; IR (neat) $\tilde{v}=3049,2959,2874,2837,1626,1583,1462,1404,1369,1314$, $1263,1191,1162,1119,1095,1080,1045,987,952,822,775,753,731,701,668,619,582$, $495,427 \mathrm{~cm}^{-1}$. 


\section{1-Methoxy-2,3-dimethylbenzene (S1):}

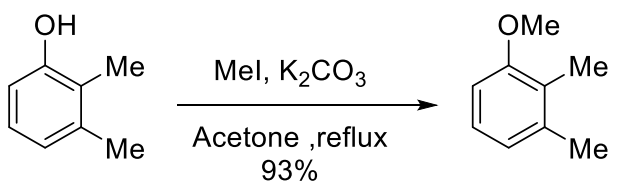

2,3-dimethylphenol (9.16 g, $75.0 \mathrm{mmol}, 1$ equiv), iodomethane (6.1 ml, $97.5 \mathrm{mmol}, 1.3 \mathrm{equiv})$ and $\mathrm{K}_{2} \mathrm{CO}_{3}(25.90 \mathrm{~g}, 187.5 \mathrm{mmol}, 2.5$ equiv) were added to a flask containing acetone $(100 \mathrm{ml})$. The resulting slurry was left to reflux overnight. The reaction was quenched with $\mathrm{MeOH}(10 \mathrm{ml})$ then cooled to r.t. and filtered; washing with excess acetone. The filtrate was concentrated to one half its volume then $\mathrm{H}_{2} \mathrm{O}(100 \mathrm{ml})$ added and the solution extracted with hexanes $(3 \times 125 \mathrm{ml})$. Combined organic extracts were dried over $\mathrm{Na}_{2} \mathrm{SO}_{4}$, filtered, and concentrated to afford the crude product as a liquid. The liquid was purified by passing it through a plug of $\mathrm{SiO}_{2}$ eluting with hexanes. Removal of the hexanes by rotary evaporator gave anisole $\mathbf{S 1}$ as a clear colourless liquid (9.52 g, 93\%). Spectra agreed with previous reports. ${ }^{[4]}{ }^{1} \mathbf{H} \mathbf{~ N M R}\left(500 \mathrm{MHz}, \mathrm{CDCl}_{3}\right) \delta \mathrm{H}$ $7.09(1 \mathrm{H}, \mathrm{t}, J=7.9 \mathrm{~Hz}), 6.80(1 \mathrm{H}, \mathrm{d}, J=7.5 \mathrm{~Hz}), 6.74(1 \mathrm{H}, \mathrm{d}, J=8.2 \mathrm{~Hz}), 3.83(3 \mathrm{H}, \mathrm{s}), 2.29$ $(3 \mathrm{H}, \mathrm{s}), 2.17(3 \mathrm{H}, \mathrm{s}) .{ }^{13} \mathrm{C}$ NMR $\left(126 \mathrm{MHz} \mathrm{CDCl}_{3}\right) \delta \mathrm{C} 157.5,137.8,125.8,125.0,122.2,107.8$, $55.5,20.0,11.5$.

\section{1,2-Bis(bromomethyl)-3-methoxybenzene (11a):}

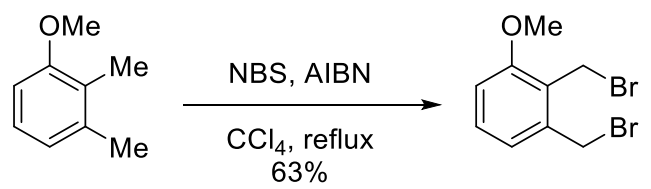

NBS (5.34 g, $30.0 \mathrm{mmol}, 2$ equiv) and AIBN (99 mg, $0.6 \mathrm{mmol}, 4 \mathrm{~mol} \%$ ) were added to a solution of anisole $\mathbf{S 1}$ (2.04 g, $15.0 \mathrm{mmol}, 1$ equiv) in $\mathrm{CCl}_{4}(50 \mathrm{ml})$. The reaction was refluxed for 1 hour at which point an additional portion of AIBN (49 mg, $0.3 \mathrm{mmol}, 2 \mathrm{~mol} \%$ ) was added and the reaction continued to reflux for another 4 hours. The solution was then cooled to $0{ }^{\circ} \mathrm{C}$, filtered, and the filtrate concentrated to afford a yellow oil. Dibromide 11a was obtained by crystallisation from $\mathrm{Et}_{2} \mathrm{O}$ and hexanes providing two crops of a white solid (2.92 $\mathrm{g}, 63 \%$ ). Spectra agreed with previous reports. ${ }^{[5]} \mathbf{1} \mathbf{H}$ NMR $\left(400 \mathrm{MHz}, \mathrm{CDCl}_{3}\right) \delta \mathrm{H} 7.30(1 \mathrm{H}, \mathrm{t}, J=8.0 \mathrm{~Hz})$, $7.0(1 \mathrm{H}, \mathrm{d}, J=7.6 \mathrm{~Hz}), 6.9(1 \mathrm{H}, \mathrm{t}, J=8.3 \mathrm{~Hz}), 4.81(2 \mathrm{H}, \mathrm{s}), 4.65(2 \mathrm{H}, \mathrm{s}), 3.9(3 \mathrm{H}, \mathrm{s}) ;{ }^{13} \mathbf{C}$ NMR $\left(126 \mathrm{MHz}, \mathrm{CDCl}_{3}\right) \delta \mathrm{C} 157.9,138.0,130.1,125.1,122.8,111.5,56.0,29.9,23.8$ LRMS (CI) m/z: 214.9 (M-Br, 94.1), 213.9 (M-Br, 100.0), 134.0 (27.3), 105.0 (60.9) .

\section{Dimethyl 4-methoxyphthalate (S2):}

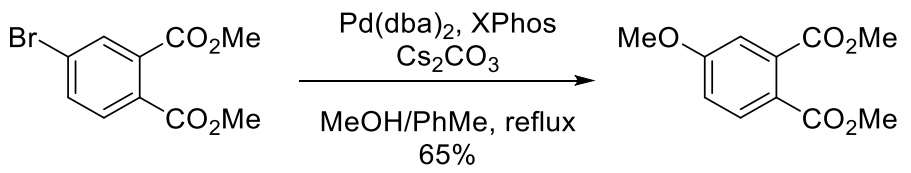

$\mathrm{MeOH}$ ( $810 \mu \mathrm{l}, 20.0 \mathrm{mmol}, 5$ equiv) was added to a solution of dimethyl 4-bromophthalate (1.09 g, 4.00 mmol, 1 equiv) in dry, degassed (sparged with argon), PhMe (20 ml). To this was added $\mathrm{Cs}_{2} \mathrm{CO}_{3}$ (1.56 g, $4.80 \mathrm{mmol}, 1.2$ equiv), $\mathrm{Pd}(\mathrm{dba})_{2}$ (11.5 mg, $0.02 \mathrm{mmol}, 0.5 \mathrm{~mol} \%$ ), and XPhos $(9.5 \mathrm{mg}, 0.02 \mathrm{mmol}, 0.5 \mathrm{~mol} \%$,). The reaction left to reflux, under an atmosphere of argon, for 5 hours then cooled to r.t. and filtered; washing with DCM. The filtrate was concentrated to afford 
a yellow liquid. The liquid was purified by column chromatography $\left(24 \mathrm{~g} \mathrm{SiO}_{2}, 10-20 \%\right.$ EtOAc in hexanes, $30 \mathrm{ml} / \mathrm{min}, 15 \mathrm{~min}$ ) to afford the anisole $\mathbf{S 2}$ as a clear colourless liquid (581 $\mathrm{mg}$, $65 \%)$. Spectra agreed with previous reports. ${ }^{[6]}{ }^{1} \mathbf{H}$ NMR $\left(400 \mathrm{MHz}, \mathrm{CDCl}_{3}\right) \delta \mathrm{H} 7.83(1 \mathrm{H}, \mathrm{d}, J=$ $8.7 \mathrm{~Hz}), 7.08(1 \mathrm{H}, \mathrm{d}, J=2.3 \mathrm{~Hz}), 7.01(1 \mathrm{H}, \mathrm{dd}, J=8.7,2.3 \mathrm{~Hz}), 3.94(3 \mathrm{H}, \mathrm{s}), 3.89(3 \mathrm{H}, \mathrm{s}), 2.06$ $(3 \mathrm{H}, \mathrm{s})$.

\section{(4-Methoxy-1,2-phenylene)dimethanol (S3):}

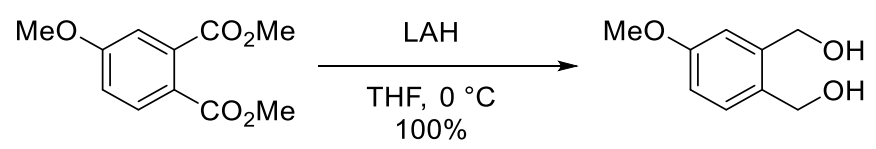

LAH (197 mg, $5.18 \mathrm{mmol}, 2$ equiv) was added in small portions, to a solution of anisole $\mathbf{S 2}$ (581 $\mathrm{mg}, 2.59 \mathrm{mmol}, 1$ equiv) in dry $\mathrm{THF}(26 \mathrm{ml})$ at $0{ }^{\circ} \mathrm{C}$ under a stream of argon. Once the addition was complete the reaction was left to stir at $0{ }^{\circ} \mathrm{C}$ under argon, for 2 hours. The reaction was then slowly quenched with water $(200 \mu \mathrm{l})$ and $15 \% \mathrm{KOH}_{(\mathrm{aq})}(200 \mu \mathrm{l})$. An additional portion of water $(600 \mu \mathrm{l})$ was then added and the solution warmed to r.t. Vigorous stirring was maintained for 1 hour at which point a white solid had formed. The solution was dried with $\mathrm{Na}_{2} \mathrm{SO}_{4}$ and flirted through celite; washing with excess THF. The filtrate was concentrated to afford diol $\mathbf{S 3}$ as a clear colourless liquid (435 mg, 100\%). Spectra agreed with previous reports. ${ }^{[7]}{ }^{1} \mathbf{H}$ NMR (500 $\left.\mathrm{MHz} \mathrm{CDCl}_{3}\right) \delta \mathrm{H} 7.27(1 \mathrm{H}, \mathrm{d}, J=8.2 \mathrm{~Hz}), 6.93(1 \mathrm{H}, \mathrm{s}), 6.83(1 \mathrm{H}, \mathrm{d}, J=8.2 \mathrm{~Hz}), 4.69(4 \mathrm{H}, \mathrm{m})$, $3.82(3 \mathrm{H}, \mathrm{s}), 3.15\left(1 \mathrm{H}\right.$, br. s), $2.85\left(1 \mathrm{H}\right.$, br. s); ${ }^{13} \mathrm{C}$ NMR $\left(126 \mathrm{MHz}, \mathrm{CDCl}_{3}\right) \delta \mathrm{C} 159.7,141.2$, $131.5,131.2,115.6,113.0,64.4,63.8,55.4$.

\section{1,2-Bis(bromomethyl)-4-methoxybenzene (11b):}

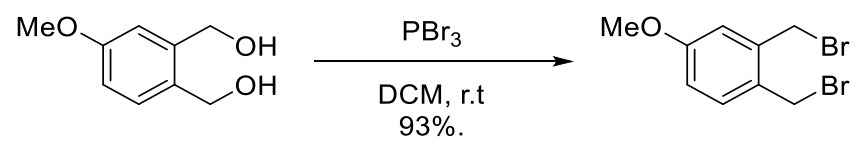

Phosphorus tribromide (180 $\mu 1,2.0 \mathrm{mmol}, 2$ equiv) was added drop-wise, via syringe, to a solution of diol S3 (168 mg, $1 \mathrm{mmol}, 1$ equiv) in dry DCM $(10 \mathrm{ml})$ at $0{ }^{\circ} \mathrm{C}$ under an argon atmosphere. The reaction was left to stir at $0{ }^{\circ} \mathrm{C}$ overnight then quenched at $0{ }^{\circ} \mathrm{C}$ with sat. $\mathrm{NaHCO}_{3}(10 \mathrm{ml})$ and vigorously stirred for 10 minutes. The solution was then extracted with $\operatorname{DCM}(3 \times 15 \mathrm{ml})$ with the combined organic extracts then dried over $\mathrm{MgSO}_{4}$, filtered, and concentrated to afford dibromide $\mathbf{1 1 b}$ as a white waxy solid (273 $\mathrm{mg}, 93 \%)$. Spectra agreed with previous reports. ${ }^{[8]}{ }^{1} \mathbf{H}$ NMR $\left(500 \mathrm{MHz}, \mathrm{CDCl}_{3}\right) \delta \mathrm{H} 7.29(1 \mathrm{H}, \mathrm{d}, J=8.5 \mathrm{~Hz}), 6.90(1 \mathrm{H}, \mathrm{d}, J=2.6$ $\mathrm{Hz}), 6.83(1 \mathrm{H}, \mathrm{dd}, J=8.4,2.7 \mathrm{~Hz}), 4.66(2 \mathrm{H}, \mathrm{s}), 4.62(2 \mathrm{H}, \mathrm{s}), 3.82(3 \mathrm{H}, \mathrm{s}) ;{ }^{13} \mathrm{C} \mathrm{NMR}(126 \mathrm{MHz}$, $\left.\mathrm{CDCl}_{3}\right) \delta \mathrm{C} 160.1,138.0,132.5,128.5,116.5,114.6,114.4,55.4,30.5,30.0 ;$ IR (neat) $\tilde{v}=3003$, 2959, 2933, 2836, 1720, 1606, 1576, 1502, 1461, 1438, 1425, 1322, 1292, 1260, 1202, 1166, $1141,1075,1034,937,857,818,767,740,728,718,649,597,577,547,524,457,439 \mathrm{~cm}^{-1}$. 


\section{Dimethyl 3-nitrophthalate (S4):}

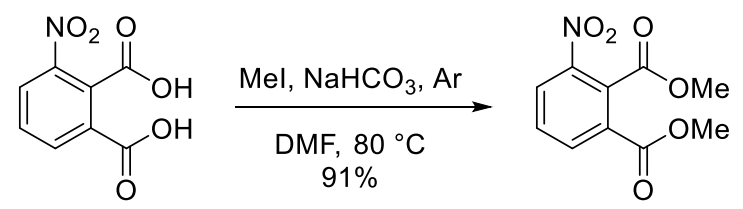

Iodomethane ( $930 \mu 1,15.0 \mathrm{mmol}, 2.7$ equiv) was added to a solution of 3-nitrophthalic acid (1.20 g $5.66 \mathrm{mmol}$, 1equiv) and $\mathrm{NaHCO}_{3}(1.68 \mathrm{~g}, 20 \mathrm{mmol}, 3.5$ equiv) in DMF $(10 \mathrm{ml})$. The reaction was then warmed to $60{ }^{\circ} \mathrm{C}$ and left to stir overnight. The reaction was quenched with $\mathrm{MeOH}(2$ $\mathrm{ml}$ ) and after being allowed to stir at $60{ }^{\circ} \mathrm{C}$ for an additional 1 hour the solution was diluted with a 1:1 solution of sat. $\mathrm{NaCl}_{(\mathrm{aq})}$ to $\mathrm{H}_{2} \mathrm{O}(125 \mathrm{ml})$. The resulting mixture was extracted with EtOAc $(150 \mathrm{ml})$ with the organic then being washed with a $1: 1$ solution of sat. $\mathrm{NaCl}_{(\mathrm{aq})}$ to $\mathrm{H}_{2} \mathrm{O}(125 \mathrm{ml})$ before the organic phase being dried over $\mathrm{Na}_{2} \mathrm{SO}_{4}$, filtered, and concentrated to afford a yellow residue. The residue was purified by column chromatography $\left(24 \mathrm{~g} \mathrm{SiO}_{2}, 0-55 \% \mathrm{EtOAc}\right.$ in hexanes, $30 \mathrm{ml} / \mathrm{min}, 20 \mathrm{~min})$ to afford diester $\mathbf{S 4}$ as a slightly yellow solid (1.23 g, 91\%). Spectra agreed with previous reports. ${ }^{[9]}{ }^{1} \mathbf{H}$ NMR $\left(500 \mathrm{MHz}, \mathrm{CDCl}_{3}\right) \delta \mathrm{H} 8.38(1 \mathrm{H}, \mathrm{dd}, J=8.3,1.2 \mathrm{~Hz})$, $8.34(1 \mathrm{H}, \mathrm{dd}, J=7.9,1.2 \mathrm{~Hz}), 7.68(1 \mathrm{H}, \mathrm{dd}, J=8.1,8.1 \mathrm{~Hz}), 4.03(3 \mathrm{H}, \mathrm{s}), 3.95(3 \mathrm{H}, \mathrm{s}) ;{ }^{13} \mathbf{C}$ NMR (126 MHz, $\left.\mathrm{CDCl}_{3}\right) \delta \mathrm{C} 165.8,164.1,146.3,135.7,131.1,130.1,130.0,128.3,53.5,53.2$.

\section{(3-Nitro-1,2-phenylene)dimethanol (S5):}

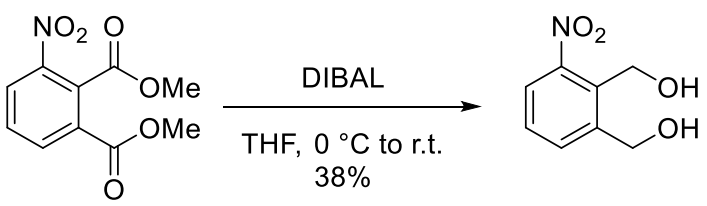

DIBAL (1 $\mathrm{M}$ in THF, $19.9 \mathrm{ml}, 19.9 \mathrm{mmol}, 4.1$ equiv) was added drop-wise to a solution of diester S4 (1.16 g, $4.86 \mathrm{mmol}, 1$ equiv) in dry THF $(20 \mathrm{ml})$ at $0{ }^{\circ} \mathrm{C}$ under argon. The reaction was then allowed to warm to r.t. and left to stir overnight. The reaction was then quenched with $\mathrm{H}_{2} \mathrm{O}(780 \mu \mathrm{l})$ and $15 \% \mathrm{KOH}_{(\mathrm{aq})}(780 \mu \mathrm{l})$ followed by a second portion of $\mathrm{H}_{2} \mathrm{O}(1.95 \mathrm{ml})$ and then left to vigorously stir at r.t. for 2 hours. The solution was then dried over $\mathrm{Na}_{2} \mathrm{SO}_{4}$ and filtered through a pad of celite; washing with excess THF. Concentration of the filtrate afforded a viscous orange liquid which was purified by column chromatography $\left(24 \mathrm{~g} \mathrm{SiO}_{2}, 10-90 \%\right.$ EtOAc in hexanes, $30 \mathrm{ml} / \mathrm{min}, 15 \mathrm{~min}$ ) to afford diol $\mathbf{S 5}$ as a yellow solid (341 $\mathrm{mg}, 38 \%$ ). Spectra agreed with previously reported data. ${ }^{[22]} \mathbf{1} \mathbf{H} \mathbf{N M R}\left(500 \mathrm{MHz}, \mathrm{CDCl}_{3}\right) \delta \mathrm{H} 7.81(1 \mathrm{H}, \mathrm{dd}, J$ $=8.2,1.1 \mathrm{~Hz}), 7.70(1 \mathrm{H}, \mathrm{d}, J=7.6 \mathrm{~Hz}), 7.48(1 \mathrm{H}, \mathrm{dd}, J=7.9,7.9 \mathrm{~Hz}), 4.88(2 \mathrm{H}, \mathrm{s}), 4.80(2 \mathrm{H}, \mathrm{s})$, 2.97 (1H, s, $\mathrm{D}_{2} \mathrm{O}$ exch.), 2.81 (1H, s, $\mathrm{D}_{2} \mathrm{O}$ exch.); ${ }^{13} \mathrm{C}$ NMR (126 MHz, $\left.\mathrm{CDCl}_{3}\right) \delta \mathrm{C} 150.9,142.9$, $133.8,132.7,129.3,123.9,63.3,57.6$.

\section{1,2-bis(Bromomethyl)-3-nitrobenzene (11c):}

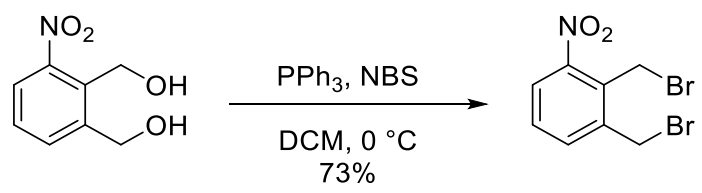

NBS (727 mg, $4.08 \mathrm{mmol}, 2.2$ equiv) was added in portions to a solution of diol $\mathbf{S 1 1}$ (340 $\mathrm{mg}$, $1.86 \mathrm{mmol}, 1$ equiv) and triphenylphosphine (1.07 g, $4.08 \mathrm{mmol}, 2.2$ equiv) in dry DCM (10 ml) at $0{ }^{\circ} \mathrm{C}$. The reaction was then allowed to stir at $0{ }^{\circ} \mathrm{C}$ for 2 hours before being diluted with excess 
$\mathrm{Et}_{2} \mathrm{O}$ and then filtered. The filtrate was concentrated to afford a yellow residue which was subjected to column chromatography $\left(20 \mathrm{~g} \mathrm{SiO}_{2}, 20 \%\right.$ hexanes in DCM) to afford dibromide 11c as a yellow solid $(420 \mathrm{mg}, 73 \%)$. Spectra agreed with previous reports. ${ }^{[10]}{ }^{\mathbf{1}} \mathbf{H} \mathbf{~ N M R}(500 \mathrm{MHz}$, $\left.\mathrm{CDCl}_{3}\right) \delta \mathrm{H} 7.88(1 \mathrm{H}, \mathrm{dd}, J=8.2,1.2 \mathrm{~Hz}), 7.64(1 \mathrm{H}, \mathrm{dd}, J=7.7,1.2 \mathrm{~Hz}), 7.47(1 \mathrm{H}, \mathrm{d}, J=8.0$ $\mathrm{Hz}), 4.86(3 \mathrm{H}, \mathrm{s}), 4.69(3 \mathrm{H}, \mathrm{s}) ;{ }^{13} \mathbf{C} \mathbf{N M R}\left(126 \mathrm{MHz}, \mathrm{CDCl}_{3}\right) \delta \mathrm{C} 150.0,139.5,135.4,131.0$, 129.8, 125.4, 28.4, 22.4; LRMS (CI) m/z: 229.8 (M-Br, 98.2), 227.9 (M-Br, 100.0), 149.0 (10.6), 120.0 (40.0), 118.0 (25.3), 91.0 (90.2), 90.0 (27.1); IR (neat) $\tilde{v}=3086,3042,2960,2873$, 1730, 1656, 1607, 1527, 1455, 1433, 1346, 1308, 1265, 1215, 1186, 1164, 1131, 1075, 942, 878, $854,832,816,782,749,703,621,566,542,482 \mathrm{~cm}^{-1}$; Mp 67-69 ${ }^{\circ} \mathrm{C}$.

\section{Dimethyl cyclopropane-1,1-dicarboxylate (S6):}

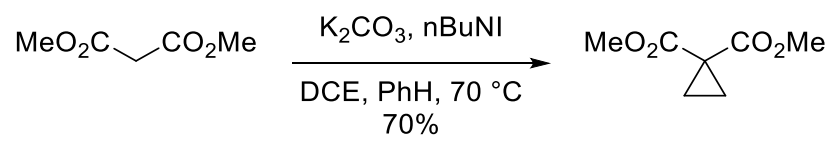

Dimethyl cyclopropane-1,1-dicarboxylate was synthesised according to the procedure reported by Heiszman et. al. ${ }^{[11]} \mathrm{H}_{2} \mathrm{O}(250 \mu \mathrm{l})$ was added to a slurry of dimethyl malonate $(5.74 \mathrm{ml}, 50.0$ mmol, 1 equiv), 1,2-dichloroethane (6.68 ml, $100 \mathrm{mmol}, 2$ equiv), $\mathrm{K}_{2} \mathrm{CO}_{3}$ (17.3 g, $125 \mathrm{mmol}, 2.5$ equiv), and tetrabutylammonium iodide (923 mg, $2.50 \mathrm{mmol}, 5 \mathrm{~mol} \%)$ in $\mathrm{PhH}(25 \mathrm{ml})$. The reaction was warmed to $70{ }^{\circ} \mathrm{C}$ and vigorously stirred overnight. The reaction was then filtered and washed with excess $\mathrm{PhH}$. The filtrate was collected and concentrated to afford a liquid contaminated with solid tetrabutylammonium iodide. The liquid was again filtered and washed with hexanes to remove the tetrabutylammonium iodide prior to being subjected to short path distillation $\left(98{ }^{\circ} \mathrm{C}, 15 \mathrm{mmHg}\right)$. This afforded diester $\mathbf{S 6}$ as a clear colourless liquid (5.55 g, 70\%). Spectra agreed with previously reported data. ${ }^{[12]}{ }^{1} \mathbf{H}$ NMR $\left(500 \mathrm{MHz}, \mathrm{CDCl}_{3}\right) \delta \mathrm{H} 3.76$ $(6 \mathrm{H}, \mathrm{s}), 1.48(4 \mathrm{H}, \mathrm{s}) ;{ }^{13} \mathbf{C} \mathbf{N M R}\left(126 \mathrm{MHz}, \mathrm{CDCl}_{3}\right) \delta \mathrm{C} 170.2,52.6,27.9,16.7$.

\section{Cyclopropane-1,1-diyldimethanol (S7):}

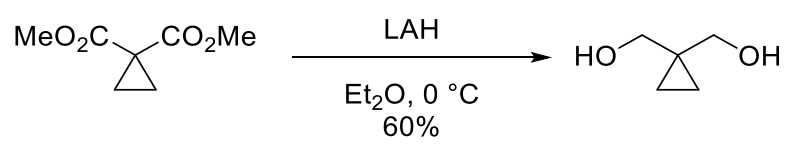

LAH (408 mg, $10.8 \mathrm{mmol}, 1.7$ equiv) was added in small portions to a solution of diester S6 (1.0 $\mathrm{g}, 6.3 \mathrm{mmol}, 1$ equiv) in dry $\mathrm{Et}_{2} \mathrm{O}(30 \mathrm{ml})$ then cooled to $0{ }^{\circ} \mathrm{C}$ under an argon atmosphere. Once the addition was complete the reaction was stirred at $0{ }^{\circ} \mathrm{C}$ for 1 hour. At this point the reaction was carefully quenched with $\mathrm{H}_{2} \mathrm{O}(400 \mu \mathrm{l})$ and $15 \% \mathrm{KOH}_{(\mathrm{aq})}(400 \mu \mathrm{l})$. An additional portion of $\mathrm{H}_{2} \mathrm{O}(1.2 \mathrm{ml})$ was then added before the solution was left to vigorously stir at r.t. for $15 \mathrm{~min}$ before being dried with $\mathrm{Na}_{2} \mathrm{SO}_{4}$ and filtered through a pad of celite; washing with excess $\mathrm{Et}_{2} \mathrm{O}$. The filtrate was collected and concentrated to afford diol S7 as a clear colourless liquid (390 mg, $60 \%)$. Spectra agreed with previously reported data. ${ }^{[13]}{ }^{1} \mathbf{H}$ NMR $\left(500 \mathrm{MHz}, \mathrm{CDCl}_{3}\right) \delta \mathrm{H} 3.63$ (4H, s), 2.52 (2H, s, D $2 \mathrm{O}$ exch.), 0.54 (4H, s); ${ }^{13} \mathbf{C}$ NMR (126 MHz, $\left.\mathrm{CDCl}_{3}\right) \delta \mathrm{C} 69.3,24.4,8.7$. 


\section{Cyclopropane-1,1-diylbis(methylene) dimethanesulfonate (S8):}

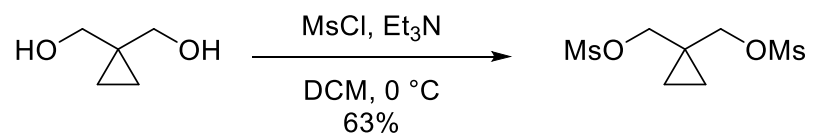

Methanesulfonyl chloride ( $890 \mu \mathrm{l}, 11.5 \mathrm{mmol}, 3$ equiv) was added drop-wise to a solution of diol S7 (390 mg, $3.82 \mathrm{mmol}, 1$ equiv) and triethylamine $(2.1 \mathrm{ml}, 15 \mathrm{mmol}, 4$ equiv) in dry DCM (9 $\mathrm{ml})$ at $0{ }^{\circ} \mathrm{C}$ under an argon atmosphere. The reaction was stirred at $0{ }^{\circ} \mathrm{C}$ for 15 minutes before being warmed to r.t. and left to stir at 2 hours. The reaction was quenched with $1 \mathrm{M} \mathrm{HCl}_{(\mathrm{aq})}(50$ $\mathrm{ml})$ and the resulting solution extracted with EtOAc $(2 \times 75 \mathrm{ml})$. Combined orgaknic extracts were dried over $\mathrm{Na}_{2} \mathrm{SO}_{4}$, filtered, and concentrated to afford an off-while solid. The solid was triturated with warm DCM and filtered to afford a first crop of white crystals (456 mg). The filtrate was concentrated, triturated with DCM, and filtered to afford a second crop of dimesylate S8 $\left(170 \mathrm{mg}, 626 \mathrm{mg}\right.$ total, 63\%). Spectra agreed with previously reported data. ${ }^{[14]}{ }^{1} \mathbf{H}$ NMR (500 $\left.\mathrm{MHz} \mathrm{CDCl}_{3}\right) \delta \mathrm{H} 4.17(4 \mathrm{H}, \mathrm{s}), 3.07$ (6H, s), 0.84. (4H, s).

\section{4-methoxy-2-methylenebutyl methanesulfonate (11d):}

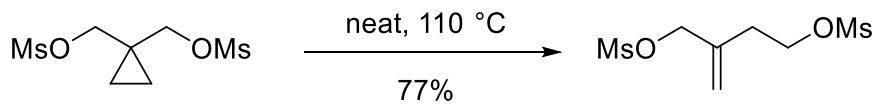

Neat dimesylate $\mathbf{S 9}$ (258 $\mathrm{mg}, 1 \mathrm{mmol}$ ) was heated in a small vail at an external temperature of $110{ }^{\circ} \mathrm{C}$ for 15 min affording a black residue which was purified by column chromatography (12 $\mathrm{g} \mathrm{SiO}_{2}, 50-80 \%$ EtOAc in hexanes, $30 \mathrm{ml} / \mathrm{min}, 10 \mathrm{~min}$ ) to afford olefin $11 d$ as a viscous liquid (200 mg, 77\%). Please note that extended reaction times result in dramatically lower yields. Reactions performed at $120{ }^{\circ} \mathrm{C}$ for 10 minutes resulted in complete decomposition. Spectra agreed with previously reported data. ${ }^{[15]}{ }^{1} \mathbf{H}$ NMR $\left(500 \mathrm{MHz}, \mathrm{CDCl}_{3}\right) \delta \mathrm{H} 5.38(1 \mathrm{H}, \mathrm{s}), 5.26(1 \mathrm{H}$, s), $4.73(2 \mathrm{H}, \mathrm{s}), 4.40(2 \mathrm{H}, \mathrm{t}, J=6.5 \mathrm{~Hz}), 3.07(3 \mathrm{H}, \mathrm{s}), 3.05(3 \mathrm{H}, \mathrm{s}), 2.63(2 \mathrm{H}, \mathrm{t}, J=6.4 \mathrm{~Hz}) ;{ }^{13} \mathrm{C}$ NMR (126 MHz, $\left.\mathrm{CDCl}_{3}\right) \delta \mathrm{C} 137.2,119.3,71.8,67.2,37.9,37.6,32.5$.

\section{2-(2-(Hydroxymethyl)phenyl)ethan-1-ol (S9):}

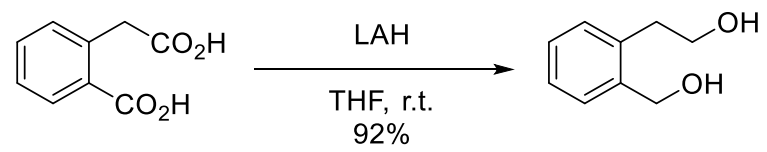

LAH (5.77 g, 150 mmol, 6 equiv) was added in small portions to a solution of homophthalic acid (4.5 g, $25 \mathrm{mmol}, 1$ equiv) in dry THF $(100 \mathrm{ml})$ under a stream of argon at $0{ }^{\circ} \mathrm{C}$. Once the addition was complete the reaction was warmed to r.t. and left to stir overnight. The reaction was quenched with $2 \mathrm{M} \mathrm{HCl}_{(\mathrm{aq})}(150 \mathrm{ml})$ followed by the addition of conc. $\mathrm{HCl}(25 \mathrm{ml})$. The resulting solution was extracted with DCM $(2 \times 150 \mathrm{ml})$. Combined organic extracts were dried with $\mathrm{Na}_{2} \mathrm{SO}_{4}$, filtered, and concentrated to afford a viscous light-brown liquid. The liquid was purified by column chromatography (60 $\mathrm{g} \mathrm{SiO}_{2}, 50 \%$ EtOAc in hexanes) to afford diol $\mathbf{S 9}$ as a clear yellow viscous liquid $(3.51 \mathrm{~g}, 92 \%)$. Spectra agreed with previous reports. ${ }^{[16]}{ }^{1} \mathbf{H}$ NMR (400 $\left.\mathrm{MHz} \mathrm{CDCl}_{3}\right) \delta \mathrm{H} 7.27-7.32(2 \mathrm{H}, \mathrm{m}), 7.20-7.24(2 \mathrm{H}, \mathrm{m}), 4.62(2 \mathrm{H}, \mathrm{s}), 3.85(2 \mathrm{H}, \mathrm{t}, \mathrm{J}=5.9 \mathrm{~Hz})$, 3.65 (2H, br. s, $\mathrm{D}_{2} \mathrm{O}$ exch.), $2.93(2 \mathrm{H}, \mathrm{t}, J=5.9 \mathrm{~Hz}) .{ }^{13} \mathrm{C} \mathrm{NMR}\left(126 \mathrm{MHz}, \mathrm{CDCl}_{3}\right) \delta \mathrm{C} 139.1$, 138.2, 130.0, 129.7, 128.5, 126.6, 63.1, 62.9, 35.0. 
1-(2-Bromoethyl)-2-(bromomethyl)benzene (11e):

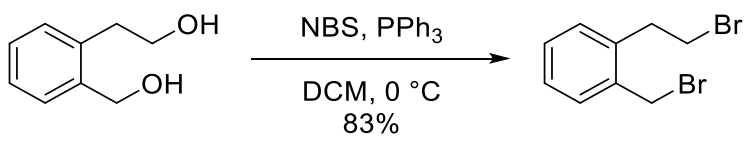

NBS (1.93 g, $10.8 \mathrm{mmol}, 2.2$ equiv) was added, in small portions, to a solution of diol S9 (750 $\mathrm{mg}, 4.93 \mathrm{mmol}, 1$ equiv) and triphenylphosphine $\left(2.84 \mathrm{~g}, 10.8 \mathrm{mmol}, 2.2\right.$ equiv) at $0{ }^{\circ} \mathrm{C}$. The reaction was then left to stir at $0{ }^{\circ} \mathrm{C}$ for 2 hours then concentrated to one third its volume, via rotary evaporation. Excess $\mathrm{Et}_{2} \mathrm{O}$ was added causing precipitation. The solution was filtered, washed with excess $\mathrm{Et}_{2} \mathrm{O}$, and the filtrate concentrated to afford a yellow residue, which was purified by column chromatography ( $24 \mathrm{~g} \mathrm{SiO}_{2}, 0-5 \%$ EtOAc in hexanes, $30 \mathrm{ml} / \mathrm{min}, 10 \mathrm{~min}$ ) to afford dibromide 11e as white solid $(1.13 \mathrm{~g}, 83 \%)$. Spectra agreed with previous reports. ${ }^{[17]}{ }^{1} \mathbf{H}$ NMR $\left(500 \mathrm{MHz}, \mathrm{CDCl}_{3}\right) \delta \mathrm{H} 7.37(1 \mathrm{H}, \mathrm{d}, J=7.6 \mathrm{~Hz}), 7.32(1 \mathrm{H}, \mathrm{m}), 7.26(2 \mathrm{H}, \mathrm{m}), 4.57(2 \mathrm{H}, \mathrm{s})$, $3.66(2 \mathrm{H}, \mathrm{t}, J=7.7 \mathrm{~Hz}), 3.32(2 \mathrm{H}, \mathrm{t}, J=7.8 \mathrm{~Hz}) ;{ }^{13} \mathrm{C} \mathbf{N M R}\left(126 \mathrm{MHz}, \mathrm{CDCl}_{3}\right) \delta \mathrm{C} 137.8,135.9$, $130.9,130.2,129.3,127.7,35.7,31.7,31.2$.

\section{2,3-Dimethyl-1,1'-biphenyl (S10):}

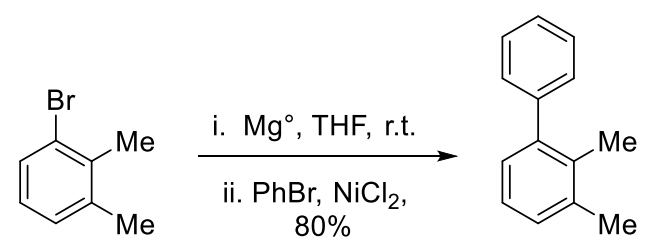

Under a stream of argon, THF (15 ml), a small chip of $\mathrm{I}_{2}$, and (1 equiv, $1.35 \mathrm{ml}, 10 \mathrm{mmol}$ ) were added to a dry flask contacting $\mathrm{Mg}^{\circ}$ turnings (243 mg, $10.0 \mathrm{mmol}, 1$ equiv), which had been flame-dried. Following the resulting exotherm, the solution was stirred at r.t. for 30 min (at which point no $\mathrm{Mg}^{\circ}$ was visible) and solution was transferred to a phial containing a solution of bromobenzene (1.10 ml, $10.5 \mathrm{mmol}, 1.05$ equiv) and $\mathrm{NiCl}_{2}(26 \mathrm{mg}, 0.20 \mathrm{mmol}, 0.02$ equiv) in dry THF ( $1 \mathrm{ml})$ under argon. The phial was sealed and heated to $66^{\circ} \mathrm{C}$ and left to stir for 3 hours. The reaction was then cooled to r.t. and diluted with $1 \mathrm{M} \mathrm{HCl}(100 \mathrm{ml})$. The resulting solution was extracted with $\mathrm{Et}_{2} \mathrm{O}(3 \times 100 \mathrm{ml})$. Combined organic extracts were dried over $\mathrm{MgSO}_{4}$, filtered, and concentrated to afford a yellow-orange liquid. The liquid was purified by column chromatography ( $24 \mathrm{~g} \mathrm{SiO}_{2}, 0-5 \%$ EtOAc in hexanes, $30 \mathrm{ml} / \mathrm{min}, 12 \mathrm{~min}$ ) to afford biphenyl S10 as a clear colourless liquid $(1.46 \mathrm{~g}, 80 \%)$. Spectra agreed with previous reports. ${ }^{[18]}{ }^{1} \mathbf{H}$ NMR $\left(500 \mathrm{MHz}, \mathrm{CDCl}_{3}\right) \delta \mathrm{H} 7.41(2 \mathrm{H}, \mathrm{m}), 7.30-7.35(3 \mathrm{H}, \mathrm{m}), 7.14-7.18(2 \mathrm{H}, \mathrm{m}), 7.09(1 \mathrm{H}, \mathrm{dd}, J=$ 7.1, $1.8 \mathrm{~Hz}), 2.35(3 \mathrm{H}, \mathrm{s}), 2.16(3 \mathrm{H}, \mathrm{s}) ;{ }^{13} \mathrm{C} \mathrm{NMR}\left(126 \mathrm{MHz}, \mathrm{CDCl}_{3}\right) \delta \mathrm{C} 142.6,142.2,137.2$, $134.0,129.4,128.8,127.9,127.6,126.6,125.2,20.7,16.9$.

\section{2,3-Bis(bromomethyl)-1,1'-biphenyl (11f):}
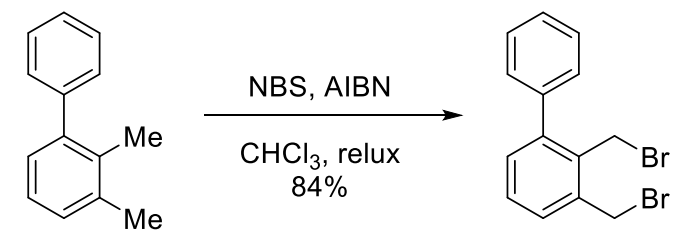

NBS (1.6 g, 9.0 mmol, 2.25 equiv) and AIBN (53 mg, $0.32 \mathrm{mmol}, 8 \mathrm{~mol} \%$ ) were added to a solution of biphenyl S10 (729 mg, $4.00 \mathrm{mmol}, 1$ equiv) in $\mathrm{CHCl}_{3}$ (40 ml) under an argon 
atmosphere. The reaction was heated to reflux and left to stir overnight. The solvent was then removed by rotary evaporation and $\mathrm{Et}_{2} \mathrm{O}$ added which resulted in precipitation of a white solid (succinimide). The precipitate was filtered off and the filtrate concentrated to afford a yellow reside which was purified by column chromatography $\left(24 \mathrm{~g} \mathrm{SiO}_{2}, 0-5 \%\right.$ DCM in hexanes, 30 $\mathrm{ml} / \mathrm{min}, 12 \mathrm{~min}$ ) to afford dibromide $11 \mathrm{f}$ as a slightly opaque colourless viscous liquid (1.14 $\mathrm{g}$, 84\%). ${ }^{1} \mathbf{H}$ NMR $\left(500 \mathrm{MHz}, \mathrm{CDCl}_{3}\right) \delta \mathrm{H} 7.40-7.47(6 \mathrm{H}, \mathrm{m}), 7.35(1 \mathrm{H}, \mathrm{t}, J=7.5 \mathrm{~Hz}), 7.24(1 \mathrm{H}$, $\mathrm{dd}, J=7.6,1.5 \mathrm{~Hz}), 4.79(2 \mathrm{H}, \mathrm{s}), 4.60(2 \mathrm{H}, \mathrm{s}) .{ }^{13} \mathbf{C} \mathbf{N M R}\left(126 \mathrm{MHz}, \mathrm{CDCl}_{3}\right) \delta \mathrm{C} 144.0,139.9$, 137.5, 133.8, 131.1, 130.5, 128.8 (2C), 128.2, 127.6, 30.6, 28.2; LRMS (CI) m/z: 260.8 (M-Br, 13.7), $258.9(\mathrm{M}-\mathrm{Br}, 12.7), 179.1(100.0), 178.2$ (30.4); IR (neat) $\tilde{v}=3058,3028,2980,1951$, 1890, 1817, 1606, 1589, 1574, 1496, 1460, 1441, 1290, 1264, 1215, 1191, 1178, 1155, 1114, 1073, 1026, 1001, 972, 913, 876, 837, 806, 761, 737, 701, $682 \mathrm{~cm}^{-1}$; Mp 46-47 ${ }^{\circ} \mathrm{C}$.

\section{2,2-Dimethylbutane-1,4-diol (S11):}

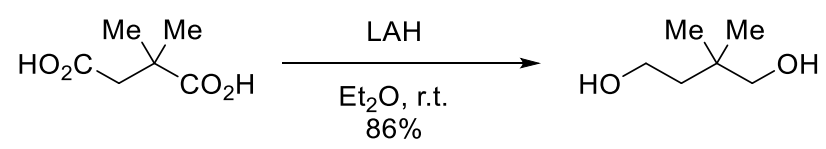

2,2-dimethylsuccinic acid (1.46 g, $10.0 \mathrm{mmol}, 1$ equiv) was added in small portions, under a stream of argon, to a suspension of LAH (, $2.24 \mathrm{~g}, 60.0 \mathrm{mmol}, 6$ equiv) in $\operatorname{dry~}^{\mathrm{Et}} \mathrm{t}_{2} \mathrm{O}$ (100 ml) at 0 ${ }^{\circ} \mathrm{C}$. The reaction was then warmed to r.t. and left to stir for 2 hours before being cooled to $0{ }^{\circ} \mathrm{C}$ and slowly quenched with water $(2.24 \mathrm{ml})$ and $15 \% \mathrm{KOH}_{(\mathrm{aq})}(2.24 \mathrm{ml})$. An additional portion of water $(6.72 \mathrm{ml})$ was then added and the solution warmed to r.t and vigorously stirred for 1 hour at which point a white solid had formed. The solution was dried with $\mathrm{Na}_{2} \mathrm{SO}_{4}$, filtered, and then flirted through a pad of celite; washing with excess $\mathrm{Et}_{2} \mathrm{O}$. The filtrate was concentrated to afford diol S11 as a clear colourless liquid (1.12 g, 86\%). Spectra agreed with previous reports. ${ }^{[19]}{ }^{1} \mathbf{H}$

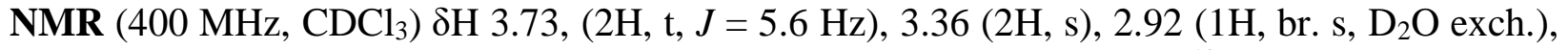
$2.49\left(1 \mathrm{H}\right.$, br. s, $\mathrm{D}_{2} \mathrm{O}$ exch.), $1.56(2 \mathrm{H}, \mathrm{t}, J=5.5 \mathrm{~Hz}), 0.92(6 \mathrm{H}, \mathrm{s}) ;{ }^{13} \mathrm{C} \mathrm{NMR}(126 \mathrm{MHz}$, $\left.\mathrm{CDCl}_{3}\right) \delta \mathrm{C} 71.6,59.2,42.7,34.9,25.0$.

\section{2,2-Dimethylbutane-1,4-diyl dimethanesulfonate (11g):}

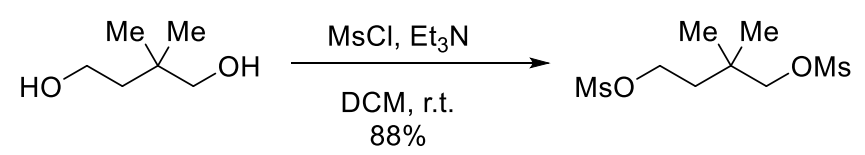

Triethylamine ( $915 \mu \mathrm{l}, 6.6 \mathrm{mmol}, 2.2$ equiv) and $\mathrm{MsCl}$ (464 $\mu \mathrm{l}, 6.0 \mathrm{mmol}, 2.0$ equiv) were added to a solution of diol S11 (354 mg, $3.0 \mathrm{mmol}, 1$ equiv) in DCM $(10 \mathrm{ml})$ at $0{ }^{\circ} \mathrm{C}$. The reaction was then allowed to warm to r.t. and left to stir for 2 hours, then diluted with DCM (50 ml) and washed with $1 \mathrm{M} \mathrm{HCl}(50 \mathrm{ml})$, The aqueous phase was then extracted with DCM $(2 \times 150 \mathrm{ml})$. Combined organic extracts were dried over $\mathrm{Na}_{2} \mathrm{SO}_{4}$, filtered, and concentrated to afford dimesylate $\mathbf{1 1 g}$ as a clear colourless oil $(728 \mathrm{mg}, 88 \%) .{ }^{\mathbf{1}} \mathbf{H} \mathbf{~ N M R}\left(500 \mathrm{MHz}, \mathrm{CDCl}_{3}\right) \delta \mathrm{H} 4.30$, $(2 \mathrm{H}, \mathrm{t}, J=6.9 \mathrm{~Hz}), 3.93(2 \mathrm{H}, \mathrm{s}), 3.02(3 \mathrm{H}, \mathrm{s}), 3.01(3 \mathrm{H}, \mathrm{s}), 1.82(2 \mathrm{H}, \mathrm{t}, J=6.9 \mathrm{~Hz}), 1.03(6 \mathrm{H}, \mathrm{s})$; ${ }^{13}$ C NMR (126 MHz, $\left.\mathrm{CDCl}_{3}\right) \delta \mathrm{C} ;$ 76.7, 66.3, 37.4, 37.1, 37.0, 33.6, 24.1; HRMS (ESI) m/z: [] ${ }^{+}$ calculated for $\left[\mathrm{C}_{8} \mathrm{H}_{18} \mathrm{O}_{6} \mathrm{~S}_{2} \mathrm{Na}\right]^{+} 297.0442$, found 297.0437; IR (neat) $\tilde{v}=2958,2927,2858,1725$, $1673,1600,2580,1462,1378,1269,1222,1121,1071,1040,957,861,834,742,705,651,488$, $471 \mathrm{~cm}^{-1}$. 
General Method - $\left(2 R, 3\right.$ ' $\left.S, 9 a^{\prime} R\right)-3$ '-Isopropyl-4-methoxy-1,2',3,3',9',9a'-hexahydro-5' $H$, $8 ' H$-spiro[indene-2,6'-oxazolo[3,2-d][1,4]thiazepin]-5'-one 7 ',7'-dioxide (13a):
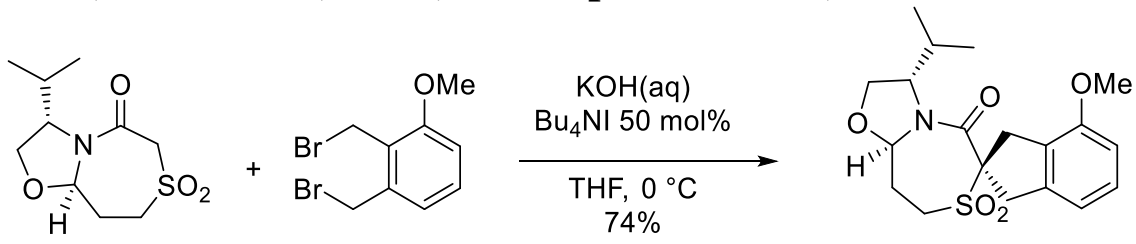

$\mathrm{KOH}_{(\mathrm{aq})}(50 \mathrm{wt} \%, 3 \mathrm{ml})$ was added drop-wise to a solution of sulfone $\mathbf{6}(111 \mathrm{mg}, 0.45 \mathrm{mmol}, 1.5$ equiv), 1,2-bis(bromomethyl)-3-methoxybenzene (11a, $88 \mathrm{mg}, 0.30 \mathrm{mmol}, 1$ equiv), and tetrabutylammonium iodide $\left(55 \mathrm{mg}, 0.15 \mathrm{mmol}, 0.5\right.$ equiv) in THF $(6 \mathrm{ml})$ at $0{ }^{\circ} \mathrm{C}$. The reaction was then vigorously stirred for 18 hours. The solution was then diluted with $\mathrm{H}_{2} \mathrm{O}(10 \mathrm{ml})$ and extracted with DCM $(3 \times 20 \mathrm{ml})$. Combined organic extracts were dried over $\mathrm{Na}_{2} \mathrm{SO}_{4}$, filtered, and concentrated to afford a yellow solid. The solid was subjected to column chromatography $\left(10 \mathrm{~g} \mathrm{SiO}_{2}, 0-6 \%\right.$ EtOAc in DCM) to afforded spirocycle 13a as a white solid (>95:5 d.r., 84 $\mathrm{mg}, 74 \%) .{ }^{1} \mathrm{H}$ NMR $\left(500 \mathrm{MHz}, \mathrm{CDCl}_{3}\right) \delta \mathrm{H} 7.16(1 \mathrm{H}, \mathrm{dd}, J=8.1,7.6 \mathrm{~Hz}), 6.76(1 \mathrm{H}, \mathrm{d}, J=7.6$ $\mathrm{Hz}), 6.70(1 \mathrm{H}, \mathrm{d}, J=8.1 \mathrm{~Hz}), 5.59(1 \mathrm{H}, \mathrm{d}, J=9.3 \mathrm{~Hz}), 4.39(1 \mathrm{H}, \mathrm{m}), 1 \mathrm{H}(1 \mathrm{H}, \mathrm{d}, J=17.9 \mathrm{~Hz})$, $3.95(2 \mathrm{H}, \mathrm{m}), 3.83(1 \mathrm{H}, \mathrm{d}, J=16.1 \mathrm{~Hz}), 3.82(3 \mathrm{H}, \mathrm{s}), 3.80(1 \mathrm{H}, \mathrm{d}, J=17.9 \mathrm{~Hz}), 3.64,3.69(1 \mathrm{H}$, $\mathrm{m}),(1 \mathrm{H}, \mathrm{d}, J=16.1 \mathrm{~Hz}), 3.31(1 \mathrm{H}, \mathrm{ddd}, J=15.3,5.4,2.9 \mathrm{~Hz}), 2.57(1 \mathrm{H}, \mathrm{m}), 2.31(1 \mathrm{H}, \mathrm{m}), 2.26$ $(1 \mathrm{H}, \mathrm{dqq}, J=7.0,7.0,4.2 \mathrm{~Hz}), 0.82(3 \mathrm{H}, \mathrm{d}, J=7.0 \mathrm{~Hz}), 0.75(3 \mathrm{H}, \mathrm{d}, J=7.0 \mathrm{~Hz}) ;{ }^{13} \mathbf{C}$ NMR $(126$ $\left.\mathrm{MHz}, \mathrm{CDCl}_{3}\right) \delta \mathrm{C} 163.1,155.8,138.4,128.7,127.8,115.7,109.0,87.8,76.8,64.5,63.4,55.2$, 48.1, 40.5, 33.9, 31.8, 27.7, 19.1, 16.1; HRMS (APCI) $\mathbf{m} / \mathbf{z}:[\mathrm{M}+\mathrm{H}]^{+}$calculated for $\left[\mathrm{C}_{19} \mathrm{H}_{26} \mathrm{NO}_{5} \mathrm{~S}\right]^{+}$380.1532, found 380.1539; IR (neat) $\tilde{v}=2963,2937,2889,2873,2837,1624$, 1592, 1472, 1451, 1438, 1398, 1389, 1372, 1330, 1316, 1293, 1278, 1265, 1238, 1221, 1187, 1172, 1134, 1096, 1066, 1050, 1035, 992, 955, 943, 931, 912, 892, 848, 838, 800, 770, 754, 731, $711,706,691 \mathrm{~cm}^{-1} ; \mathbf{M p} 242-245^{\circ} \mathrm{C}$.

$\left(2 S / R, 3\right.$ ' $\left.S, 9 a^{\prime} R\right)$-3'-Isopropyl-5-methoxy-1,2',3,3',9',9a'-hexahydro-5' H,8'H-spiro[indene2,6'-oxazolo[3,2-d][1,4] thiazepin]-5'-one 7',7'-dioxide (13b):
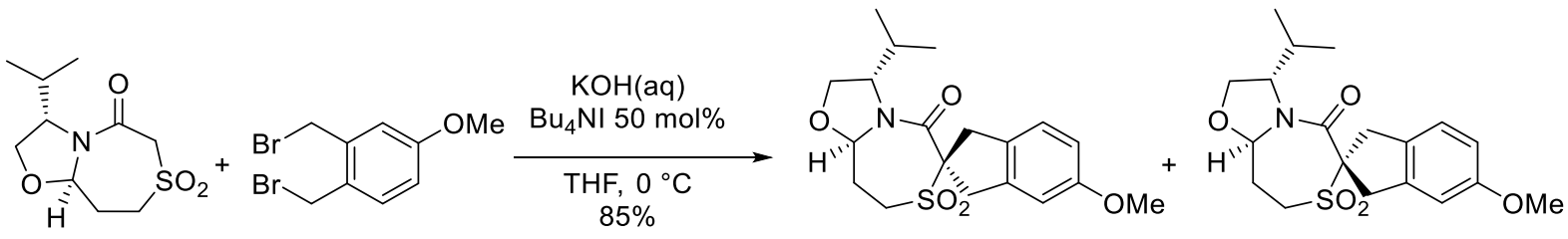

3:1 d.r.

Spirocycle 13b was synthesised according to the example procedure from dibromide 11b (294 $\mathrm{mg}, 1.0 \mathrm{mmol}, 1$ equiv), sulfone 6 ( $371 \mathrm{mg}, 1.5 \mathrm{mmol}, 1.5$ equiv), tetrabutylammonium iodide (185 mg, $0.5 \mathrm{mmol}, 0.5$ equiv), THF (40 ml), and $\mathrm{KOH}_{\text {(aq) }}(50 \mathrm{wt} \%, 5 \mathrm{ml})$. Once complete, the reaction was diluted with $\mathrm{H}_{2} \mathrm{O}(50 \mathrm{ml})$ and extracted with $\mathrm{DCM}(3 \times 50 \mathrm{ml})$. Combined organic extracts were dried over $\mathrm{MgSO}_{4}$, filtered, and concentrated to afford a white solid. The solid was subjected to column chromatography $\left(40 \mathrm{~g} \mathrm{SiO}_{2}, 4 \%\right.$ EtOAc in DCM) to afford spirocycle $\mathbf{1 3 b}$ as a white solid (3:1 d.r., $321 \mathrm{mg}, 85 \%$ ) however, the diastereomers proved completely inseparable. HRMS (APCI) m/z: $[\mathrm{M}+\mathrm{H}]^{+}$calculated for $\left[\mathrm{C}_{19} \mathrm{H}_{26} \mathrm{NO}_{5} \mathrm{~S}\right]^{+} 380.1532$, found 380.1545; IR (neat) $\tilde{v}=2961,2932,2901,2873,2835,1621,1594,1497,1463,1439,1409$, 1389, 1372, 1354, 1331, 1313, 1290, 1257, 1229, 1201, 1185, 1169, 1147, 1128, 1098, 1063, $1031,1009,988,952,931,909,879,840,802,765,754,732,702 \mathrm{~cm}^{-1}$. 


\section{$\left(2 S, 3 ' S, 9 a^{\prime} R\right)-13 b:$}

${ }^{1} \mathbf{H}$ NMR $\left(500 \mathrm{MHz}, \mathrm{CDCl}_{3}\right) \delta \mathrm{H} 7.17(1 \mathrm{H}, \mathrm{d}, J=8.4 \mathrm{~Hz}), 6.77(1 \mathrm{H}, \mathrm{dd}, J=8.4,2.4 \mathrm{~Hz}), 6.70$ $(1 \mathrm{H}, \mathrm{d}, J=2.1 \mathrm{~Hz}), 5.60(1 \mathrm{H}, \mathrm{d}, J=9.1 \mathrm{~Hz}), 4.38(1 \mathrm{H}, \mathrm{m}), 4.27(1 \mathrm{H}, \mathrm{d}, J=17.0 \mathrm{~Hz}), 3.96(2 \mathrm{H}$, $\mathrm{m}), 3.80(1 \mathrm{H}, \mathrm{d}, J=17.0 \mathrm{~Hz}), 3.79(1 \mathrm{H}, \mathrm{d}, J=16.1 \mathrm{~Hz}), 3.77(3 \mathrm{H}, \mathrm{s}), 3.69(1 \mathrm{H}, \mathrm{m}), 3.61(1 \mathrm{H}, \mathrm{d}$, $J=16.0 \mathrm{~Hz}), 3.31(1 \mathrm{H}$, ddd, $J=15.3,6.0,2.7 \mathrm{~Hz}), 2.58(1 \mathrm{H}, \mathrm{m}), 2.32(1 \mathrm{H}, \mathrm{m}), 2.25(1 \mathrm{H}, \mathrm{m})$, $0.82(3 \mathrm{H}, \mathrm{d}, J=7.2 \mathrm{~Hz}), 0.75(3 \mathrm{H}, \mathrm{d}, J=6.9 \mathrm{~Hz}) ;{ }^{13} \mathbf{C} \mathbf{~ N M R}\left(126 \mathrm{MHz}, \mathrm{CDCl}_{3}\right) \delta \mathrm{C} 163.1,159.2$, 137.9, 131.8, 125.0,113.7, 109.3, 87.9, 77.5, 64.6, 63.5, 55.5, 48.2, 40.3, 35.7, 31.9, 27.8, 19.1, 16.2 .

\section{$\left(2 R, 3 ' S, 9 a^{\prime} R\right)-13 b:$}

${ }^{1} \mathbf{H}$ NMR $\left(500 \mathrm{MHz}, \mathrm{CDCl}_{3}\right) \delta \mathrm{H} 7.04(1 \mathrm{H}, \mathrm{d}, J=8.4 \mathrm{~Hz}), 6.81(1 \mathrm{H}, \mathrm{d}, J=2.1 \mathrm{~Hz}), 6.73(1 \mathrm{H}, \mathrm{dd}$, $J=8.3,2.4 \mathrm{~Hz}), 5.60(1 \mathrm{H}, \mathrm{d}, J=9.1 \mathrm{~Hz}), 4.37(1 \mathrm{H}, \mathrm{m}), 4.31(1 \mathrm{H}, \mathrm{d}, J=17.4 \mathrm{~Hz}), 3.96(2 \mathrm{H}, \mathrm{m})$, $3.84(1 \mathrm{H}, \mathrm{d}, J=17.5 \mathrm{~Hz}), 3.78(3 \mathrm{H}, \mathrm{s}), 3.75(1 \mathrm{H}, \mathrm{d}, J=14.5 \mathrm{~Hz}), 3.69(1 \mathrm{H}, \mathrm{m}), 3.57(1 \mathrm{H}, \mathrm{d}, J=$ $15.4 \mathrm{~Hz}), 3.31(1 \mathrm{H}, \mathrm{m}), 2.58(1 \mathrm{H}, \mathrm{m}), 2.32(1 \mathrm{H}, \mathrm{m}), 2.25(1 \mathrm{H}, \mathrm{m}), 0.81(3 \mathrm{H}, \mathrm{d}, J=7.0 \mathrm{~Hz}), 0.75$ $(3 \mathrm{H}, \mathrm{d}, J=6.8 \mathrm{~Hz}) ;{ }^{13} \mathrm{C} \mathbf{N M R}\left(126 \mathrm{MHz}, \mathrm{CDCl}_{3}\right) \delta \mathrm{C} 163.1,159.8,141.4,128.2,124.4,113.9$, $109.0,87.9,77.6,64.6,63.5,55.4,48.2,39.4,36.6,32.0,27.8,19.1,16.2$.

\section{(2S,3'S,9a' $R$ )-3'-isopropyl-4-nitro-1,2',3,3',9',9a'-hexahydro-5' $H, 8$ ' $H$-spiro[indene-2,6'- oxazolo[3,2-d][1,4]thiazepin]-5'-one 7',7'-dioxide (13c):}
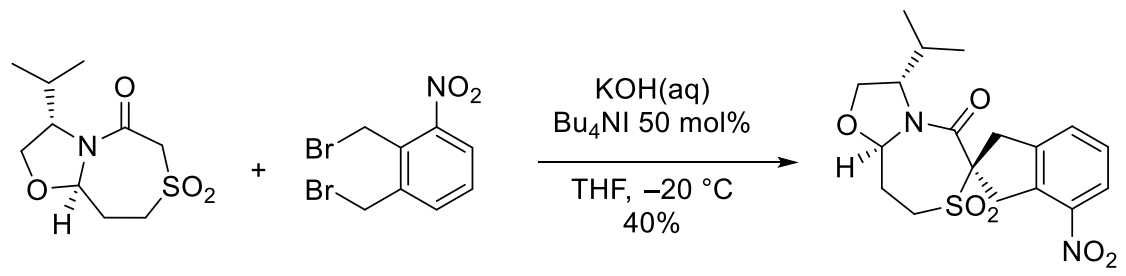

9:1 d.r.

Spirocycle 13c was synthesised according to the example procedure from dibromide 11c (93 $\mathrm{mg}$, $0.3 \mathrm{mmol}, 1$ equiv), sulfone 6 (111 $\mathrm{mg}, 0.45 \mathrm{mmol}, 1.5$ equiv), tetrabutylammonium iodide (110 $\mathrm{mg}, 0.3 \mathrm{mmol}, 1.0$ equiv), THF (6 ml), $\mathrm{KOH}_{(\mathrm{aq})}(50 \mathrm{wt} \%, 1.5 \mathrm{ml})$ and sat. $\mathrm{NaCl}(1.5 \mathrm{ml})$. Once complete, the reaction was diluted with $\mathrm{H}_{2} \mathrm{O}(10 \mathrm{ml})$ and extracted with DCM $(3 \times 20 \mathrm{ml})$. Combined organic extracts were dried over $\mathrm{MgSO}_{4}$, filtered, and concentrated to afford a white solid. The solid was subjected to column chromatography (10 $\mathrm{g} \mathrm{SiO}_{2}, 5 \% \mathrm{EtOAc}$ in DCM) to afford spirocycle 13c as a white solid (9:1 d.r., $47 \mathrm{mg}, 40 \%)$. The major isomer could, in large part, be separated, by column chromatography (10 $\mathrm{g} \mathrm{SiO}_{2}, 50$ to $80 \%$ EtOAc in hexanes). ${ }^{1} \mathbf{H}$ NMR $\left(500 \mathrm{MHz}, \mathrm{CDCl}_{3}\right) \delta \mathrm{H} 8.09(1 \mathrm{H}, \mathrm{d}, J=8.2 \mathrm{~Hz}), 7.62(1 \mathrm{H}, \mathrm{d}, J=7.5 \mathrm{~Hz}), 7.45(1 \mathrm{H}, \mathrm{dd}, J=$ $8.2,7.5 \mathrm{~Hz}), 5.71(1 \mathrm{H}, \mathrm{d}, J=9.4 \mathrm{~Hz}), 4.50(1 \mathrm{H}, \mathrm{d}, J=18.0 \mathrm{~Hz}), 4.38(1 \mathrm{H}, \mathrm{m}), 4.29(1 \mathrm{H}, \mathrm{d}, J=$ $18.3 \mathrm{~Hz}), 4.14(1 \mathrm{H}, \mathrm{d}, J=18.3 \mathrm{~Hz}), 3.95-4.01(3 \mathrm{H}, \mathrm{m}), 3.82(1 \mathrm{H}, \mathrm{ddd}, J=15.6,13.3,3.1 \mathrm{~Hz})$, $3.35(1 \mathrm{H}, \mathrm{ddd}, J=15.6,5.5,2.9 \mathrm{~Hz}), 2.57-2.65(1 \mathrm{H}, \mathrm{m}), 2.38(1 \mathrm{H}, \mathrm{m}), 2.27(1 \mathrm{H}, \mathrm{dqq}, J=7.0$, 7.0, $4.1 \mathrm{~Hz}), 0.84(3 \mathrm{H}, \mathrm{d}, J=7.0 \mathrm{~Hz}), 0.77(3 \mathrm{H}, \mathrm{d}, J=7.0 \mathrm{~Hz}) ;{ }^{13} \mathbf{C} \mathbf{N M R}\left(126 \mathrm{MHz}, \mathrm{CDCl}_{3}\right) \delta \mathrm{C}$ 162.3, 144.7, 144.0, 133.3, 130.4, 129.3, 123.0, 87.8, 64.6, 65.7, 47.8, 40.9, 36.5, 31.9, 27.8, 19.1, 16.2; HRMS (APCI) $\mathbf{m} / \mathbf{z}:[\mathrm{M}+\mathrm{H}]^{+}$calculated for $\left[\mathrm{C}_{18} \mathrm{H}_{22} \mathrm{~N}_{2} \mathrm{O}_{6} \mathrm{~S}\right]^{+} 395.1277$, found 395.1284; IR (neat) $\tilde{v}=2959,2929,2874,1629,1528,1483,1462,1407,1391,1352,1326$, 1312, 1293, 1226, 1187, 1164, 1128, 1098, 1068, 1051, 1032, 989, 950, 837, 801, 756, 732, 703, $536,512,499,485,473 \mathrm{~cm}^{-1} ;[\boldsymbol{\alpha}]_{\mathbf{D}}^{\mathbf{2 2}}-206.5\left(c 1.0, \mathrm{CHCl}_{3}\right) ; \mathbf{M p} 245-246{ }^{\circ} \mathrm{C}$. 
$\left(1 R, 3 ' S, 9 a^{\prime} R\right)-3$ '-Isopropyl-3-methylenetetrahydro-5' $H, 8^{\prime} H$-spiro[cyclopentane-1,6'oxazolo[3,2-d][1,4]thiazepin]-5'-one 7',7'-dioxide (13d):

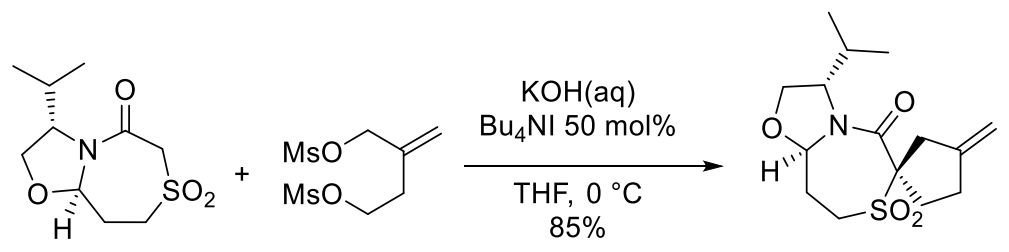

Spirocycle 13d was synthesised according to the example procedure from dimesylate 11d (75 $\mathrm{mg}, 0.30 \mathrm{mmol}, 1$ equiv), sulfone 6 (111 $\mathrm{mg}, 0.45 \mathrm{mmol}, 1.5$ equiv), tetrabutylammonium iodide $\left(55 \mathrm{mg}, 0.15 \mathrm{mmol}, 0.5\right.$ equiv), THF $(6 \mathrm{ml})$, and $\mathrm{KOH}_{(\mathrm{aq})}(50 \mathrm{wt} \%, 3 \mathrm{ml})$. Once complete, the reaction was diluted with $\mathrm{H}_{2} \mathrm{O}(10 \mathrm{ml})$ and extracted with $\mathrm{DCM}(3 \times 20 \mathrm{ml})$. Combined organic extracts were dried over $\mathrm{MgSO}_{4}$, filtered, and concentrated to afford a yellow solid. The solid was subjected to column chromatography $\left(10 \mathrm{~g} \mathrm{SiO}_{2}, 0-4 \%\right.$ EtOAc in DCM) to afforded spirocycle 13d as a white solid (>95:5 d.r., $95 \mathrm{mg}, 95 \%) .{ }^{1} \mathbf{H} \mathbf{~ N M R ~}\left(500 \mathrm{MHz}, \mathrm{CDCl}_{3}\right) \delta \mathrm{H} 5.56$ $(1 \mathrm{H}, \mathrm{d}, J=9.1 \mathrm{~Hz}), 5.03(1 \mathrm{H}, \mathrm{tt}, J=1.9,1.9 \mathrm{~Hz}), 4.93(1 \mathrm{H}, \mathrm{tt}, J=2.1,2.1 \mathrm{~Hz}), 4.39(1 \mathrm{H}, \mathrm{m})$, $3.91-3.96(2 \mathrm{H}, \mathrm{m}), 3.61(1 \mathrm{H}, \mathrm{dd}, J=16.8,1.6 \mathrm{~Hz}), 3.55(1 \mathrm{H}, \mathrm{ddd}, J=16.1,13.3,3.0 \mathrm{~Hz}), 3.27$ $(1 \mathrm{H}$, ddd, $J=15.3,5.7,2.8 \mathrm{~Hz}), 3.20(1 \mathrm{H}, \mathrm{dd}, J=16.8,1.4 \mathrm{~Hz}), 2.66(1 \mathrm{H}, \mathrm{m}), 2.26-2.56(6 \mathrm{H}$, $\mathrm{m}), 0.88(3 \mathrm{H}, \mathrm{d}, J=7.0 \mathrm{~Hz}), 0.81(3 \mathrm{H}, \mathrm{d}, J=6.7 \mathrm{~Hz}) ;{ }^{13} \mathbf{C ~ N M R}\left(126 \mathrm{MHz}, \mathrm{CDCl}_{3}\right) \delta \mathrm{C} 162.7$, 145.8, 107.4, 87.9, 77.1, 64.4, 63, 7, 48.4, 35.8, 32.6, 31.9, 31.7, 27.9, 19.2, 16.2; HRMS (APCI) $\mathbf{m} / \mathbf{z}:[\mathrm{M}+\mathrm{H}]^{+}$calculated for $\left[\mathrm{C}_{15} \mathrm{H}_{24} \mathrm{NO}_{4} \mathrm{~S}\right]^{+} 314.1421$, found 314.1430; IR (neat) $\tilde{v}=3075,2958$, 2931, 2897, 2873, 1738, 1661, 1623, 1485, 1463, 1438, 1404, 1388, 1373, 1364, 1316, 1300, 1288, 1253, 1229, 1206, 1186, 1171, 1127, 1097, 1050, 1033, 1007, 991, 965, 954, 934, 912, 878, 841, 802, 784, 776, 754, 730, $701 \mathrm{~cm}^{-1}$; $[\boldsymbol{\alpha}]_{\mathbf{D}}^{22}-206.0\left(c 1.0, \mathrm{CHCl}_{3}\right) ; \mathbf{M p ~ 2 8 5 - 2 8 6}{ }^{\circ} \mathrm{C}$.

$\left(2 R, 3^{\prime} S, 9 a^{\prime} R\right)-3$ '-Isopropyl-2',3,3',4,9',9a'-hexahydro-1H,5' $H, 8^{\prime} H$-spiro[naphthalene-2,6'oxazolo[3,2-d][1,4]thiazepin]-5'-one $7^{\prime}, 7^{\prime}$-dioxide (13e):
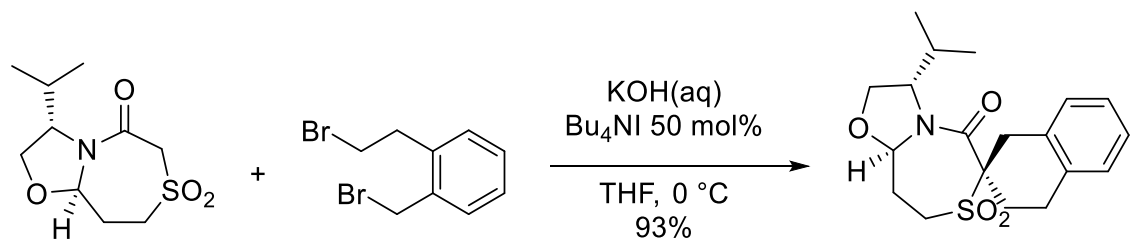

Spirocycle 13e was synthesised according to the example procedure from dibromide 11e (278 $\mathrm{mg}, 1.0 \mathrm{mmol}, 1$ equiv), sulfone 6 ( $371 \mathrm{mg}, 1.5 \mathrm{mmol}, 1.5$ equiv), tetrabutylammonium iodide (185 mg, $0.5 \mathrm{mmol}, 0.5$ equiv), THF (40 ml), and $\mathrm{KOH}_{(\mathrm{aq})}(50 \mathrm{wt} \%, 5 \mathrm{ml})$. Once complete, the reaction was diluted with $\mathrm{H}_{2} \mathrm{O}(50 \mathrm{ml})$ and extracted with $\mathrm{DCM}(3 \times 50 \mathrm{ml})$. Combined organic extracts were dried over $\mathrm{MgSO}_{4}$, filtered, and concentrated to afford a white solid. The solid was subjected to column chromatography $\left(40 \mathrm{~g} \mathrm{SiO}_{2}, 2-6 \%\right.$ EtOAc in DCM) to afford spirocycle 13e as a white solid (>95:5 d.r., $337 \mathrm{mg}, 93 \%) .{ }^{1} \mathbf{H}$ NMR $\left(500 \mathrm{MHz}, \mathrm{CDCl}_{3}\right) \delta \mathrm{H} 7.24(1 \mathrm{H}, \mathrm{d}, J=$ $7.7 \mathrm{~Hz}), 7.17(1 \mathrm{H}, \mathrm{t}, 7.3 \mathrm{~Hz}), 7.10(1 \mathrm{H}, \mathrm{t}, J=7.3 \mathrm{~Hz}), 7.03(1 \mathrm{H}, \mathrm{d}, J=7 / 5 \mathrm{~Hz}), 5.67(1 \mathrm{H}, \mathrm{d}, J=$ $10.0 \mathrm{~Hz}), 4.37(1 \mathrm{H}, \mathrm{m}), 3.87-3.96(2 \mathrm{H}, \mathrm{m}), 3.77(1 \mathrm{H}, \mathrm{d}, J=16.1 \mathrm{~Hz}), 3.71(1 \mathrm{H}, \mathrm{m}), 3.48(1 \mathrm{H}$, d, $J=15.9 \mathrm{~Hz}), 3.28(1 \mathrm{H}, \mathrm{ddd}, J=15.5,5.5,2.7 \mathrm{~Hz}), 2.98(1 \mathrm{H}, \mathrm{dt}, J=16.8,4.4 \mathrm{~Hz}), 2.76(1 \mathrm{H}$, m), $2.51-2.66(2 \mathrm{H}, \mathrm{m}), 2.41(1 \mathrm{H}, \mathrm{td}, J=12.8,5.0 \mathrm{~Hz}), 2.29(1 \mathrm{H}, \mathrm{m}), 2.15(\mathrm{qqd}, J=6.8,6.8,3.3$ $\mathrm{Hz}), 0.80(3 \mathrm{H}, \mathrm{d}, J=7.0, \mathrm{~Hz}), 0.79(3 \mathrm{H}, \mathrm{d}, J=7.0 \mathrm{~Hz}) ;{ }^{13} \mathrm{C}$ NMR $\left(126 \mathrm{MHz}, \mathrm{DMSO}-d_{6}\right) \delta \mathrm{C}$ 162. 2, 133.9, 132.6, 128.9, 127.9, 126.9, 125.9, 87.7, 71.7, 63.9, 63.7, 47.5, 32.3, 29.3, 27.8, 
26.2, 25.9, 19.4, 16.1; HRMS (APCI) $\mathbf{m} / \mathbf{z}:[\mathrm{M}+\mathrm{H}]^{+}$calculated for $\left[\mathrm{C}_{19} \mathrm{H}_{26} \mathrm{NO}_{4} \mathrm{~S}\right]^{+}$364.1583, found 364.1586; IR (neat) $\tilde{v}=3021,2962,2930,2897,2847,1620,1586,1496,1463,1438$, $1401,1387,1371,1360,1309,1284,1255,1228,1181,1169,1128,1109,1067,1055,1033$, $1015,990,958,917,899,883,842,817,794,778,753,738,705,692,603,561,541,528,512$,

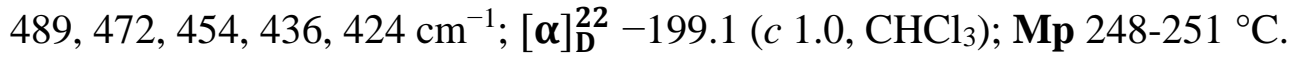

\section{$\left(2 R, 3 ' S, 9 a^{\prime} R\right)-3 '$-Isopropyl-4-phenyl-1,2',3,3',9',9a'-hexahydro-5' $H, 8^{\prime} H$-spiro[indene-2,6'- oxazolo[3,2-d][1,4]thiazepin]-5'-one $7^{\prime}, 7^{\prime}$ '-dioxide (13f):}
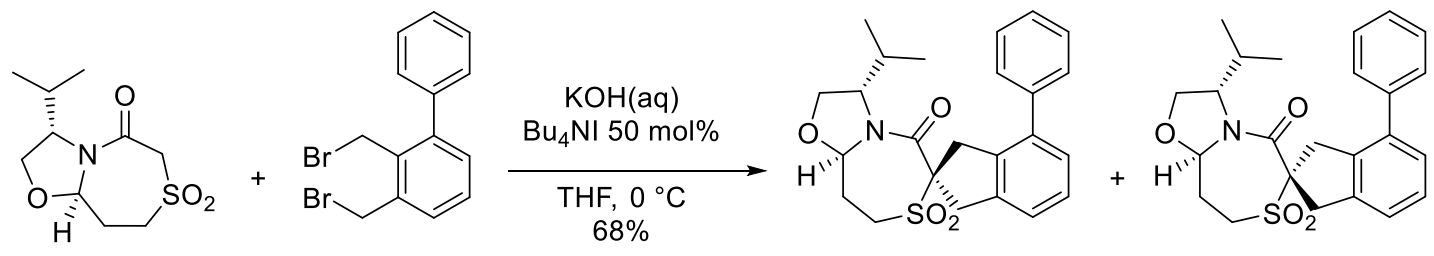

4:1 d.r.

Spirocycle 13f was synthesised according to the example procedure from dibromide $11 \mathbf{f}$ (102 $\mathrm{mg}, 0.3 \mathrm{mmol}, 1$ equiv), sulfone 6 (111 $\mathrm{mg}, 0.45 \mathrm{mmol}, 1.5$ equiv), tetrabutylammonium iodide (55 mg, $0.5 \mathrm{mmol}, 0.5$ equiv), THF $(6 \mathrm{ml})$, and $\mathrm{KOH}_{(\mathrm{aq})}(50 \mathrm{wt} \%, 3 \mathrm{ml})$. Once complete, the reaction was diluted with $\mathrm{H}_{2} \mathrm{O}(10 \mathrm{ml})$ and extracted with DCM $(3 \times 20 \mathrm{ml})$. Combined organic extracts were dried over $\mathrm{MgSO}_{4}$, filtered, and concentrated to afford a white solid. The solid was subjected to column chromatography (10 $\mathrm{g} \mathrm{SiO}_{2}, 5 \%$ EtOAc in DCM) to afford spirocycle $13 f$ as a white solid (4:1 d.r., $87 \mathrm{mg}, 68 \%)$. The major isomer $((R, S, R)-\mathbf{1 3 f})$ could, in large part, be separated, by column chromatography $\left(12 \mathrm{~g} \mathrm{SiO}_{2}, 20-50 \%\right.$ EtOAc in hexanes, at $20 \mathrm{ml} / \mathrm{min}$ over $15 \mathrm{~min}) .{ }^{1} \mathbf{H}$ NMR $\left(500 \mathrm{MHz}, \mathrm{CDCl}_{3}\right) \delta \mathrm{H} 7.50(2 \mathrm{H}, \mathrm{m}), 7.43(2 \mathrm{H}, \mathrm{m}), 7.35(1 \mathrm{H}, \mathrm{tt}, J=7.3$, $1.2 \mathrm{~Hz}), 7.24-7.29(2 \mathrm{H}, \mathrm{m}), 7.15(1 \mathrm{H}, \mathrm{d}, J=7.2 \mathrm{~Hz}), 5.63(1 \mathrm{H}, \mathrm{d}, J=9.4 \mathrm{~Hz}), 4.43(1 \mathrm{H}, \mathrm{d}, J=$ $17.5 \mathrm{~Hz}), 4.36(1 \mathrm{H}, \mathrm{dt}, J=4.3,4.3 \mathrm{~Hz}), 3.95(2 \mathrm{H}, \mathrm{d}, J=4.4 \mathrm{~Hz}), 3.89(1 \mathrm{H}, \mathrm{d}, J=17.1 \mathrm{~Hz}), 3.89$ $(1 \mathrm{H}, \mathrm{d}, J=17.1 \mathrm{~Hz}), 3.71(1 \mathrm{H}, \mathrm{d}, J=16.0 \mathrm{~Hz}), 3.70(1 \mathrm{H}, \mathrm{m}), 3.30(1 \mathrm{H}, \mathrm{ddd}, J=15.3,5.5,2.7$ $\mathrm{Hz}), 2.57(1 \mathrm{H}, \mathrm{m}), 2.31(1 \mathrm{H}, \mathrm{m}), 2.26(1 \mathrm{H}, \mathrm{m}), 0.82(3 \mathrm{H}, \mathrm{d}, J=7.0 \mathrm{~Hz}), 0.76(3 \mathrm{H}, \mathrm{d}, J=6.9 \mathrm{~Hz})$; ${ }^{13}$ C NMR $\left(126 \mathrm{MHz}, \mathrm{CDCl}_{3}\right) \delta \mathrm{C} 162.9,140.1,138.7,137.7,137.1,128.5$ 128.3, 127.6, 127.3, 122.6, 87.8, 76.8, 64.5, 63.4, 48.1, 40.2, 36.2, 31.9, 27.7, 19.1, 16.1; HRMS (APCI) m/z: $[\mathrm{M}+\mathrm{H}]^{+}$calculated for $\left[\mathrm{C}_{24} \mathrm{H}_{28} \mathrm{NO}_{4} \mathrm{~S}\right]^{+} 426.1739$, found 426.172; IR (neat) $\tilde{v}=3058,2962,2929$, 2875, 1641, 1466, 1431, 1391, 1369, 1311, 1292, 1266, 1226, 1187, 1162, 1129, 1098, 1065, 1034, 989, 954, 910, 835, 791, 758, 731, 700, 649, 612, 586, 567, 539, 497, 476, $446 \mathrm{~cm}^{-1}$; $[\boldsymbol{\alpha}]_{\mathbf{D}}^{22}-207.9\left(c 1.0, \mathrm{CHCl}_{3}\right) ; \mathbf{M p} 200-204{ }^{\circ} \mathrm{C}$.

\section{(1S,3'S,9a' $R)$-3'-isopropyl-3,3-dimethyltetrahydro-5' $H, 8$ ' $H$-spiro[cyclopentane-1,6'-} oxazolo[3,2-d][1,4]thiazepin]-5' -one 7',7'-dioxide (13g):
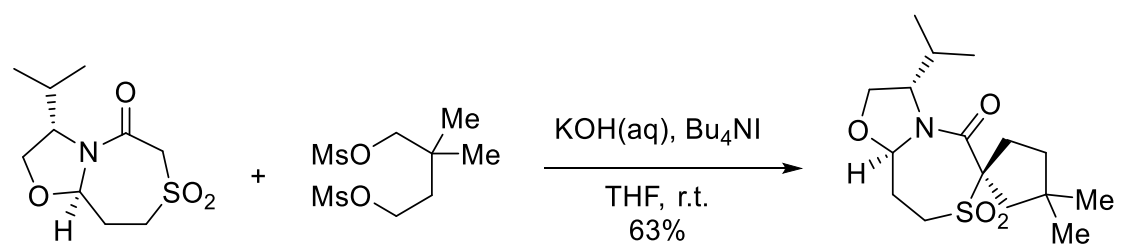

$\mathrm{KOH}_{(\mathrm{aq})}(50 \mathrm{wt} \%, 3 \mathrm{ml})$ was added drop-wise to a solution of sulfone 6 (74 mg, $0.3 \mathrm{mmol}, 1$ equiv), dimesylate $\mathbf{1 1 g}$ (184 $\mathrm{mg}, 0.60 \mathrm{mmol}, 2$ equiv), and tetrabutylammonium iodide (442 $\mathrm{mg}$, $1.2 \mathrm{mmol}, 4$ equiv) in THF $(6 \mathrm{ml})$ at r.t. The reaction was then vigorously stirred for 4 days. The 
solution was diluted with $\mathrm{H}_{2} \mathrm{O}(10 \mathrm{ml})$ and extracted with DCM $(3 \times 30 \mathrm{ml})$. Combined organic extracts were dried over $\mathrm{MgSO}_{4}$, filtered, and concentrated to afford a yellow solid. The solid was subjected to column chromatography $\left(10 \mathrm{~g} \mathrm{SiO}_{2}, 2 \%\right.$ EtOAc in DCM) to afforded spirocycle $\mathbf{1 3 g}$ as a white solid $(62 \mathrm{mg}, 63 \%)$. ${ }^{1} \mathbf{H}$ NMR $\left(500 \mathrm{MHz}, \mathrm{CDCl}_{3}\right) \delta \mathrm{H} 5.54(1 \mathrm{H}, \mathrm{d}, J=9.6 \mathrm{~Hz})$, $4.38(1 \mathrm{H}, \mathrm{m}), 3.90-3.98(2 \mathrm{H}, \mathrm{m}), 3.63(1 \mathrm{H}, \mathrm{ddd}, J=15.3,13.4,3.0 \mathrm{~Hz}), 3.11-3.22(2 \mathrm{H}, \mathrm{m})$, $2.46-2.61(2 \mathrm{H}, \mathrm{m}), 2.34(1 \mathrm{H}, \mathrm{qqd}, J=7.0,7.0,3.9 \mathrm{~Hz}), 2.18(1 \mathrm{H}, \mathrm{m}), 2.15(2 \mathrm{H}, \mathrm{s}), 1.57-1.70$ $(2 \mathrm{H}, \mathrm{m}), 1.15(3 \mathrm{H}, \mathrm{s}), 0.95(3 \mathrm{H}, \mathrm{s}), 0.89(3 \mathrm{H}, \mathrm{d}, J=7.0 \mathrm{~Hz}), 0.82(3 \mathrm{H}, \mathrm{d}, J=7.0 \mathrm{~Hz}) ;{ }^{13} \mathbf{C}$ NMR $\left(126 \mathrm{MHz}, \mathrm{CDCl}_{3}\right) \delta \mathrm{C} 164.2,88.0,77.8,64.4,63.4,48.2,47.9,41.4,39.9,32.1,29.3,28.8,27.9$, 27.8, 19.3, 16.2; HRMS (APCI) m/z: $[\mathrm{M}+\mathrm{H}]^{+}$calculated for $\left[\mathrm{C}_{16} \mathrm{H}_{28} \mathrm{NO}_{4} \mathrm{~S}\right]^{+} 330.1739$ found 330.1741 ; IR (neat) $v=2958,2933,2870,1710,1622,1487,1463,1437,1405,1389,1370$, 1352, 1334, 1309, 1289, 1228, 1201, 1172, 1129, 1096, 1050, 1032, 1021, 985, 953, 882, 848,

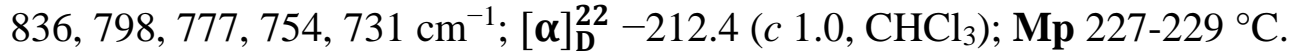

$(3 S, 6(R / S), 9 \mathrm{a} R)$-6-Benzyl-3-isopropyltetrahydro-8H-oxazolo[3,2-d][1,4]thiazepin-5(6H)-one 7,7-dioxide $((S, R, R)-16$ and $(S, S, R)-15)$ :

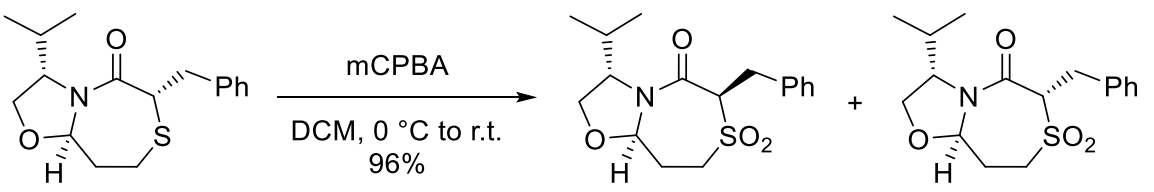

6:5 d.r.

mCPBA ( $83 \mathrm{wt} \%, 363 \mathrm{mg}, 1.74 \mathrm{mmol}, 2.1$ equiv) was added to a solution of (3S,6S,9aR)-6benzyl-3-isopropyltetrahydro- $8 H$-oxazolo[3,2-d][1,4]thiazepin-5(6H)-one ${ }^{[3]}(252 \mathrm{mg} 0.83 \mathrm{mmol}$, 1 equiv) in dry DCM $(10 \mathrm{ml})$ at $0{ }^{\circ} \mathrm{C}$ under a stream of argon. The reaction was then warmed to r.t. and left to stir overnight under an atmosphere of argon. Sat. $\mathrm{NaHCO}_{3(\mathrm{aq})}(25 \mathrm{ml})$ was added and the resulting solution extracted with DCM $(3 \times 40 \mathrm{ml})$. Combined organic extracts were dried over $\mathrm{Na}_{2} \mathrm{SO}_{4}$, filtered, and concentrated to afford a mixture of sulfones $(S, R, R)-\mathbf{1 5}$ and $(S, S, R)-\mathbf{1 5}$ as a white solid (6:5 d.r.). The product was used in further reaction without additional purification, however small amounts of each diastereomer were isolated for characterisation purposes.

\section{$(3 S, 6 R, 9 \mathrm{a} R)-6$-Benzyl-3-isopropyltetrahydro-8H-oxazolo[3,2-d][1,4]thiazepin-5(6H)-one} 7,7-dioxide $((S, R, R)-15)$ :

${ }^{1} \mathbf{H}$ NMR $\left(500 \mathrm{MHz}, \mathrm{CDCl}_{3}\right) \delta \mathrm{H} 7.27(3 \mathrm{H}, \mathrm{m}), 7.22(2 \mathrm{H}, \mathrm{m}), 5.38(1 \mathrm{H}, \mathrm{dd}, J=7.5,2.0 \mathrm{~Hz}), 4.28$ $(1 \mathrm{H}, \mathrm{m}), 4.08(1 \mathrm{H}, \mathrm{dd}, J=10.7,2.3 \mathrm{~Hz}), 4.00(1 \mathrm{H}, \mathrm{dd}, J=9.2,6.9 \mathrm{~Hz}), 3.88(1 \mathrm{H}, \mathrm{dd}, J=9.2,3.4$ $\mathrm{Hz}), 3.70(1 \mathrm{H}, \mathrm{dd}, J=13.8,10.7 \mathrm{~Hz}), 3.39(3 \mathrm{H}, \mathrm{m}), 2.56(1 \mathrm{H}, \mathrm{m}), 2.39(1 \mathrm{H}, \mathrm{m}), 2.26(1 \mathrm{H}, \mathrm{m})$, $0.76(3 \mathrm{H}, \mathrm{d}, J=7.0 \mathrm{~Hz}), 0.60(3 \mathrm{H}, \mathrm{d}, J=6.9 \mathrm{~Hz}) ;{ }^{13} \mathbf{C} \mathbf{N M R}\left(126 \mathrm{MHz}, \mathrm{CDCl}_{3}\right) \delta \mathrm{C} 159.3,137.4$, 129.1, 128.6, 126.9, 88.0, 68.5, 65.8, 61.9, 52.2, 31.6, 27.9, 27.6, 18.9, 15.7; HRMS (ESI) m/z: $[\mathrm{M}+\mathrm{Na}]^{+}$calculated for $\left[\mathrm{C}_{17} \mathrm{H}_{23} \mathrm{NO}_{4} \mathrm{NaS}\right]^{+} 360.1240$, found 360.1232; IR (neat) $\tilde{v}=2958,2927$, $2858,1725,1673,1600,1580,1462,1378,1269,1222,1121,1071,1040,957,861,834,743$, $704,651,488,471 \mathrm{~cm}^{-1}$.

$(3 S, 6 S, 9 \mathrm{a} R)-6$-Benzyl-3-isopropyltetrahydro-8H-oxazolo[3,2-d][1,4]thiazepin-5(6H)-one 7,7-dioxide $((S, S, R)-15)$ :

${ }^{1} \mathbf{H}$ NMR $\left(500 \mathrm{MHz}, \mathrm{CDCl}_{3}\right) \delta \mathrm{H} 7.33(2 \mathrm{H}, \mathrm{m}), 7.24-7.38(3 \mathrm{H}, \mathrm{m}), 5.65(1 \mathrm{H}, \mathrm{d}, J=9.9 \mathrm{~Hz})$, $4.32(1 \mathrm{H}, \mathrm{ddd}, J=12.1,4.5,2.9 \mathrm{~Hz}), 4.26(1 \mathrm{H}, \mathrm{m}), 3.93(1 \mathrm{H}, \mathrm{dd}, J=9.2,1.8 \mathrm{~Hz}), 3.88(1 \mathrm{H}, \mathrm{dd}$, 
$J=9.2,6.3 \mathrm{~Hz}), 3.60(2 \mathrm{H}, \mathrm{m}), 3.28(1 \mathrm{H}, \mathrm{dd}, J=14.3,12.1 \mathrm{~Hz}), 3.24(1 \mathrm{H}, \mathrm{m}), 2.55(1 \mathrm{H}, \mathrm{m}), 2.32$ $(1 \mathrm{H}, \mathrm{m}), 2.04(1 \mathrm{H}, \mathrm{d}$ of septet, $J=7.1,3.7 \mathrm{~Hz}), 0.77(3 \mathrm{H}, \mathrm{d}, J=7.0 \mathrm{~Hz}), 0.67(3 \mathrm{H}, \mathrm{d}, J=6.9$ $\mathrm{Hz}) ;{ }^{13} \mathrm{C}$ NMR $\left(126 \mathrm{MHz}, \mathrm{CDCl}_{3}\right) \delta \mathrm{C} 160.4,134.4,129.0,128.5,127.8,86.9,74.1,64.3,63.2$, 47.8, 32.8, 32.1, 27.9, 19.4, 16.0; HRMS (ESI) m/z: $[\mathrm{M}+\mathrm{Na}]^{+}$calculated for $\left[\mathrm{C}_{17} \mathrm{H}_{23} \mathrm{NO}_{4} \mathrm{NaS}^{+}\right.$ 360.1240, found 360.1235; IR (neat) $\tilde{v}=3063,3031,2960,2931,2898,2874,1660,1630,1456$, 1422 , 1390, 1372, 1315, 1292, 1232, 1166, 1120, 1098, 1031, 952, 878, 843, 757, 738, 697, 571, $540,492,473 \mathrm{~cm}^{-1}$.

$(3 S, 6 R, 9 \mathrm{a} R)$-6-Benzyl-3-isopropyl-6-methyltetrahydro-8H-oxazolo[3,2-d][1,4]thiazepin5(6H)-one 7,7-dioxide (16):
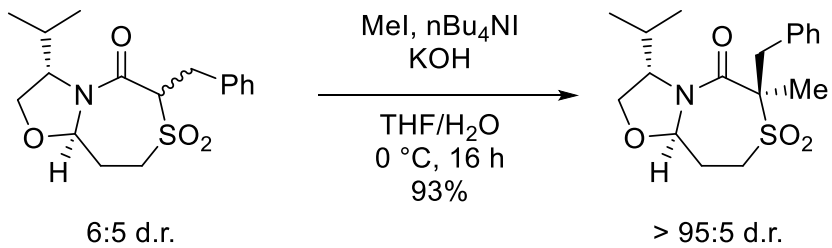

$\mathrm{KOH}_{(\mathrm{aq})}(50 \mathrm{wt} \%, 1.5 \mathrm{ml})$ was added drop-wise to a solution of sulfones $(S, R, R)-\mathbf{1 5}$ and $(S, S, R)-$ 15 (6:5 d.r., $50 \mathrm{mg}, 0.15 \mathrm{mmol}, 1$ equiv), iodomethane ( $23 \mu \mathrm{l}, 0.37 \mathrm{mmol}, 2.5$ equiv), and TBAI (27 mg, $0.075 \mathrm{mmol}, 0.5$ equiv) in THF $(6 \mathrm{ml})$ at $0{ }^{\circ} \mathrm{C}$. The reaction was then vigorously stirred for 18 hours. The solution was then diluted with $\mathrm{H}_{2} \mathrm{O}(15 \mathrm{ml})$ and extracted with DCM $(3 \times 15$ $\mathrm{ml})$. Combined organic extracts were dried over $\mathrm{Na}_{2} \mathrm{SO}_{4}$, filtered, and concentrated to afford a white solid. The solid was subjected to column chromatography (10 g SiO $2,4 \%$ EtOAc in DCM) and afforded sulfone $\mathbf{1 6}$ as a white solid and as a single diastereomer (49 $\mathrm{mg}, 93 \%)$. ${ }^{\mathbf{1}} \mathbf{H}$ NMR $\left(500 \mathrm{MHz}, \mathrm{CDCl}_{3}\right) \delta \mathrm{H} 7.39-7.42(2 \mathrm{H}, \mathrm{m}), 7.22-7.29(3 \mathrm{H}, \mathrm{m}), 5.49(1 \mathrm{H}, \mathrm{d}, J=10.8 \mathrm{~Hz}), 4.49$ $(1 \mathrm{H}, \mathrm{m}), 3.95(1 \mathrm{H}, \mathrm{dd}, J=9.0,6.0 \mathrm{~Hz}), 3.88(1 \mathrm{H}, \mathrm{d}, J=13.7 \mathrm{~Hz}), 3.82(1 \mathrm{H}, \mathrm{dd}, J=9.0,4.3 \mathrm{~Hz})$, $2.05(1 \mathrm{H}, \mathrm{m}), 3.35(1 \mathrm{H}, \mathrm{d}, J=13.7 \mathrm{~Hz}), 3.18(1 \mathrm{H}, \mathrm{dt}, J=15.2,4.3 \mathrm{~Hz}), 2.24(2 \mathrm{H}, \mathrm{m}), 2.18(1 \mathrm{H}$, m), $1.58(3 \mathrm{H}, \mathrm{s}), 0.85(3 \mathrm{H}, \mathrm{d}, J=7.0 \mathrm{~Hz}), 0.85(3 \mathrm{H}, \mathrm{d}, J=7.0 \mathrm{~Hz}) ;{ }^{13} \mathbf{C} \mathbf{N M R}(126 \mathrm{MHz}$, $\left.\mathrm{CDCl}_{3}\right) \delta \mathrm{C} 165.1,135.4,131.7,128.2,127.2,87.5,72.3,64.6,63.6,48.5,35.9,31.0,28.1,18.9$, 18.6, 16.2; HRMS (ESI) $\mathbf{~ m / z : ~}[\mathrm{M}+\mathrm{Na}]^{+}$calculated for $\left[\mathrm{C}_{18} \mathrm{H}_{25} \mathrm{NO}_{4} \mathrm{NaS}\right]^{+} 374.1396$, found 374.1387; IR (neat) $\tilde{v}=3088,3064,3030,2960,2932,2896,2874,1620,1495,1456,1402$, 1390, 1377, 1370, 1358, 1310, 1286, 1229, 1207, 1185, 1168, 1129, 1083, 1054, 1032, 898, 957, $935,840,796,783,773,754,737,700,609,594,560,540,530,513,474,458,416 \mathrm{~cm}^{-1} ;[\boldsymbol{\alpha}]_{\mathbf{D}}^{22}$ -0.2 (c 1.0, $\left.\mathrm{CHCl}_{3}\right) ; \mathbf{M p} 208-209^{\circ} \mathrm{C}$.

\section{Example Procedure - $(R)-N-((S)-1-h y d r o x y-3-m e t h y l b u t a n-2-y l)-4-m e t h o x y-2-m e t h y l-2,3-$ dihydro-1H-indene-2-carboxamide (17a):}
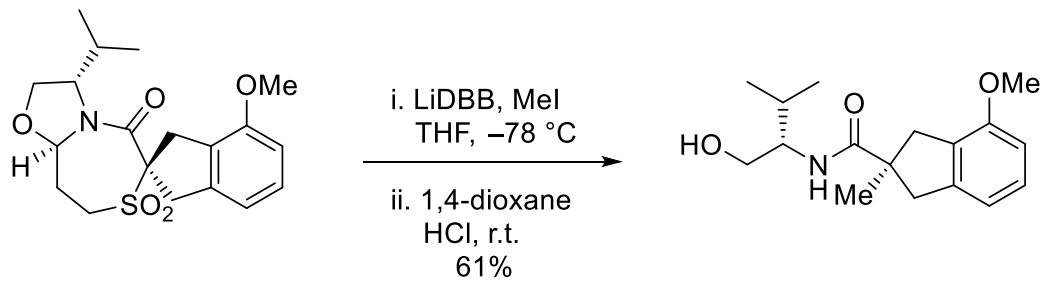

LiDBB (0.4 M, 2.1 equiv, $2.6 \mathrm{ml}$ ) drop-wise to a solution of spirocycle 13a (159 mg, $0.42 \mathrm{mmol}$, 1 equiv), that had been azeotropically dried with PhMe $(2 \times 15 \mathrm{ml})$, in dry and degassed THF (10 $\mathrm{ml}$ ) at $-78{ }^{\circ} \mathrm{C}$. Following the addition, the solution left to stir at $-78{ }^{\circ} \mathrm{C}$ for $20 \mathrm{~min}$. Iodomethane (157 $\mu$ l, $2.51 \mathrm{mmol}, 6$ equiv), which had been passed through a column of activated, basic, 
Brockmann I aluminium oxide, was then added drop-wise via glass syringe and the reaction allowed to stir at $-78{ }^{\circ} \mathrm{C}$ for 4 hours. The reaction was warmed to r.t. and all volatiles removed under reduced pressure. The resulting residue was dissolved in 1,4-dioxane $(10 \mathrm{ml})$ and $1 \mathrm{M}$ $\mathrm{HCl}_{(\mathrm{aq})}(10 \mathrm{ml})$ added. After stirring at r.t. for 12 hours the solution was adjusted to $\mathrm{pH} 7$ with $\mathrm{NaOH}_{(\mathrm{aq})}(15 \%$ w.t. $)$ and allowed to stir at r.t for 1 hour before being extracted with EtOAc $(3 \times$ $50 \mathrm{ml}$ ). Combined organic extracts were dried over $\mathrm{Na}_{2} \mathrm{SO}_{4}$, filtered, and concentrated to afford a yellow solid which was purified by column chromatography $\left(20 \mathrm{~g} \mathrm{SiO}_{2}, 40-50 \%\right.$ EtOAc in hexanes). Amide 17a was isolated as a white solid (74 mg, 61\%). ${ }^{1} \mathbf{H}$ NMR (500 MHz, $\left.\mathrm{CDCl}_{3}\right) \delta \mathrm{H} 7.16(1 \mathrm{H}, \mathrm{dd}, J=7.8,7.8 \mathrm{~Hz}), 6.83(1 \mathrm{H}, \mathrm{d}, J=7.5 \mathrm{~Hz}), 6.70(1 \mathrm{H}, \mathrm{d}, J=8.1 \mathrm{~Hz}), 5.75$ $\left(1 \mathrm{H}\right.$, br. d, $J=7.0 \mathrm{~Hz}, \mathrm{D}_{2} \mathrm{O}$ exch.), $3.82(3 \mathrm{H}, \mathrm{s}), 3.61-3.76(3 \mathrm{H}, \mathrm{m}), 3.42(1 \mathrm{H}, \mathrm{d}, J=15.9 \mathrm{~Hz})$, $3.28(1 \mathrm{H}, \mathrm{d}, J=16.1 \mathrm{~Hz}), 2.87(1 \mathrm{H}, \mathrm{d}, J=715.8 \mathrm{~Hz}), 2.87(1 \mathrm{H}, \mathrm{d}, J=15.8 \mathrm{~Hz}), 2.65(1 \mathrm{H}, \mathrm{t}, J=$ $5.1 \mathrm{~Hz}, \mathrm{D}_{2} \mathrm{O}$ exch.), $1.86(1 \mathrm{H}, \mathrm{qqd}, J=6.8,6.8,6.8 \mathrm{~Hz}), 1.40(3 \mathrm{H}, \mathrm{s}), 0.91(3 \mathrm{H}, \mathrm{d}, J=6.8 \mathrm{~Hz})$, $0.85(3 \mathrm{H}, \mathrm{d}, J=6.8 \mathrm{~Hz}) ;{ }^{13} \mathrm{C}$ NMR $\left(126 \mathrm{MHz}, \mathrm{CDCl}_{3}\right) \delta \mathrm{C} 178.9,156.2,143.4,128.7,128.4$, 117.2, 108.3, 64.7, 57.3, 55.2, 50.2, 44.8, 41.0, 29.0, 25.8, 19.6, 18.5; HRMS (APCI) m/z: $[\mathrm{M}+\mathrm{H}]^{+}$calculated for $\left[\mathrm{C}_{17} \mathrm{H}_{26} \mathrm{NO}_{3}\right]^{+} 292.1913$, found 292.1911; IR (neat) $\tilde{v}=3311,3261,3079$, 2960, 2933, 2877, 2833, 1624, 1590, 1556, 1483, 1470, 1464, 1439, 1389, 1371, 1351, 1328, 1316, 1299, 1274, 1262, 1241, 1189, 1171, 1155, 1116, 1075, 1033, 970, 900, 888, 864, 827, $813,771,750,725,704 \mathrm{~cm}^{-1} ;[\boldsymbol{\alpha}]_{\mathbf{D}}^{22}+44.9\left(c 1.0, \mathrm{CHCl}_{3}\right) ; \mathbf{M p} 140-141^{\circ} \mathrm{C}$.

\section{(R)-2-Ethyl- $N$-((S)-1-hydroxy-3-methylbutan-2-yl)-4-methoxy-2,3-dihydro-1H-indene-2- carboxamide (17b):}
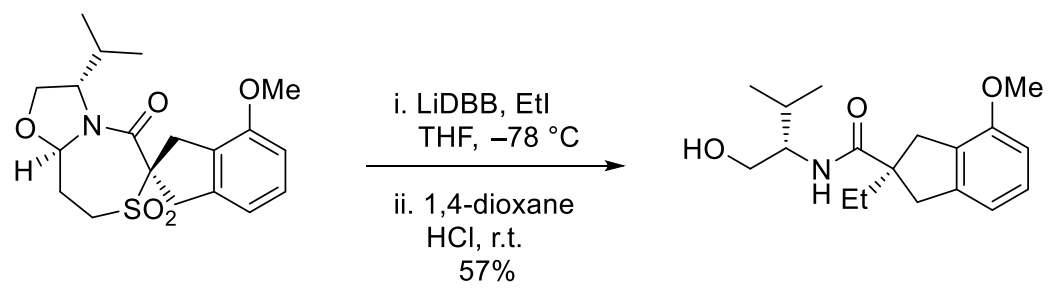

Amide 13b was synthesised according to the example procedure using LiDBB $(0.4 \mathrm{M}, 2.4 \mathrm{ml}$, $0.94 \mathrm{mmol}, 2.1$ equiv), spirocycle $13 \mathrm{a}$ (170 mg, $0.45 \mathrm{mmol}, 1$ equiv), degassed dry THF (12 ml), iodoethane (145 $\mu \mathrm{l}, 1.8 \mathrm{mmol}, 4$ equiv), which had been passed through a column of activated, basic, Brockmann I aluminium oxide, 1,4-dioxane $(12 \mathrm{ml})$ and $1 \mathrm{M} \mathrm{HCl}_{(\mathrm{aq})}(6 \mathrm{ml})$. EtOAc $(3 \times$ $30 \mathrm{ml}$ ) was employed for the aqueous work up with combined organic extracts dried over $\mathrm{Na}_{2} \mathrm{SO}_{4}$, filtered, and concentrated to afford a yellow oil which was purified by column chromatography (20 $\mathrm{g} \mathrm{SiO}_{2}, 40-50 \%$ EtOAc in hexanes). Amide 13b was isolated as a colourless oil $(79 \mathrm{mg}, 57 \%) .{ }^{1} \mathbf{H}$ NMR $\left(500 \mathrm{MHz}, \mathrm{CDCl}_{3}\right) \delta \mathrm{H} 7.14(1 \mathrm{H}, \mathrm{t}, J=7.8 \mathrm{~Hz}), 6.81(1 \mathrm{H}$, d, $J=7.5 \mathrm{~Hz}), 6.68(1 \mathrm{H}, \mathrm{d}, J=8.1 \mathrm{~Hz}), 5.73\left(1 \mathrm{H}, \mathrm{d}, J=7.7 \mathrm{~Hz}, \mathrm{D}_{2} \mathrm{O}\right.$ exch.), $3.82(3 \mathrm{H}, \mathrm{s}), 3.74$ $(1 \mathrm{H}, \mathrm{m}), 3.67(1 \mathrm{H}, \mathrm{m}), 3.61(1 \mathrm{H}, \mathrm{m}), 3.36(1 \mathrm{H}, \mathrm{d}, J=16.1 \mathrm{~Hz}), 3.24(1 \mathrm{H}, \mathrm{d}, J=16.2 \mathrm{~Hz}), 2.94$ $(1 \mathrm{H}, \mathrm{d}, J=16.2 \mathrm{~Hz}), 2.92(1 \mathrm{H}, \mathrm{d}, J=16.2 \mathrm{~Hz}), 2.79$ (1H, br. s, $\mathrm{D}_{2} \mathrm{O}$ exch.), $1.84(1 \mathrm{H}, \mathrm{m}), 1.73$ $(1 \mathrm{H}, \mathrm{m}), 0.93(3 \mathrm{H}, \mathrm{t}, J=7.4 \mathrm{~Hz}), 0.87(3 \mathrm{H}, \mathrm{d}, J=6.8 \mathrm{~Hz}), 0.83(3 \mathrm{H}, \mathrm{d}, J=6.9 \mathrm{~Hz}){ }^{13} \mathbf{C} \mathbf{N M R}$ $\left(126 \mathrm{MHz}, \mathrm{CDCl}_{3}\right) \delta \mathrm{C} 177.9,155.9,143.6,128.7,128.3,117.0,108.2,64.7,57.3,55.2(4)$, 55.2(0), 42.9, 38.4, 32.1, 28.9, 18.4, 9.8; HRMS (ESI) $\mathbf{~ m / z : ~}[\mathrm{M}+\mathrm{Na}]^{+}$calculated for $\left[\mathrm{C}_{18} \mathrm{H}_{27} \mathrm{NO}_{3} \mathrm{Na}\right]^{+} 328.1883$, found 328.1879; IR (neat) $\tilde{v}=3306,3260,3070,2962,2936,2901$, 2874, 2837, 1716, 1619, 1591, 1551, 1482, 1467, 1385, 1371, 1353, 1338, 1316, 1298, 1262, 1230, 1185, 1168, 1149, 1109, 1074, 1056, 1022, 1009, 967, 939, 885, 858, 828, 814, 765, 736,

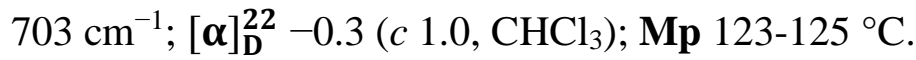




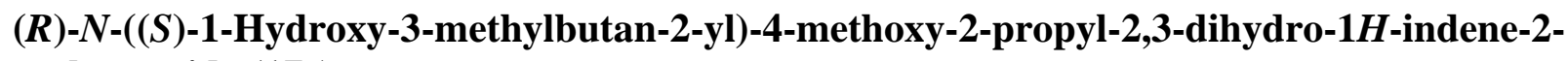
carboxamide (17c):

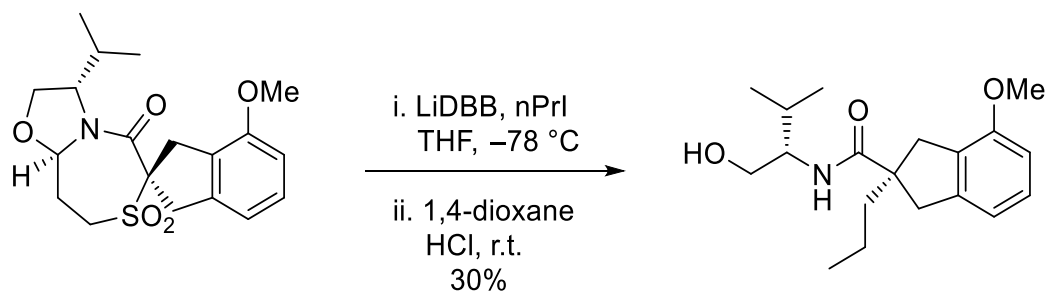

Amide 17c was synthesised according to the example procedure using LiDBB $(0.4 \mathrm{M}, 1.65 \mathrm{ml}$, $0.664 \mathrm{mmol}, 2.1$ equiv), spirocycle $13 \mathrm{a}$ (120 $\mathrm{mg}, 0.316 \mathrm{mmol}, 1$ equiv), degassed dry THF (6 $\mathrm{ml}$ ), 1-iodopropane (123 $\mu \mathrm{l}, 1.26 \mathrm{mmol}, 4$ equiv), which had been passed through a column of activated, basic, Brockmann I aluminium oxide, 1,4-dioxane $(6 \mathrm{ml})$ and $1 \mathrm{M} \mathrm{HCl}_{(\mathrm{aq})}(2.5 \mathrm{ml})$. EtOAc $(3 \times 20 \mathrm{ml})$ was employed for the aqueous work up with combined organic extracts dried over $\mathrm{Na}_{2} \mathrm{SO}_{4}$, filtered, and concentrated to afford a yellow oil which was purified by column chromatography (15 $\mathrm{g} \mathrm{SiO}_{2}, 40-60 \%$ EtOAc in hexanes). Amide 17c was isolated as a colourless oil $(30 \mathrm{mg}, 30 \%)$. ${ }^{1} \mathbf{H}$ NMR $\left(500 \mathrm{MHz}, \mathrm{CDCl}_{3}\right) \delta \mathrm{H} 7.15(1 \mathrm{H}, \mathrm{dd}, J=7.8,7.8 \mathrm{~Hz})$, $6.81(1 \mathrm{H}, \mathrm{d}, J=7.5 \mathrm{~Hz}), 6.68(1 \mathrm{H}, \mathrm{d}, J=8.1 \mathrm{~Hz}), 5.71\left(1 \mathrm{H}\right.$, br. d, $J=7.3 \mathrm{~Hz}, \mathrm{D}_{2} \mathrm{O}$ exch.), 3.82 $(3 \mathrm{H}, \mathrm{s}), 3.71(1 \mathrm{H}, \mathrm{m}), 3.59-3.68(2 \mathrm{H}, \mathrm{m}), 3.36(1 \mathrm{H}, \mathrm{d}, J=16.1 \mathrm{~Hz}), 3.25(1 \mathrm{H}, \mathrm{d}, J=16.2 \mathrm{~Hz})$, $2.95(1 \mathrm{H}, \mathrm{d}, J=16.0 \mathrm{~Hz}), 2.92(1 \mathrm{H}, \mathrm{d}, J=16.1 \mathrm{~Hz}), 2.69\left(1 \mathrm{H}, \mathrm{br} . \mathrm{s}, \mathrm{D}_{2} \mathrm{O}\right.$ exch. $), 1.83(1 \mathrm{H}, \mathrm{m})$, $1.61-1.78(2 \mathrm{H}, \mathrm{m}), 1.34(2 \mathrm{H}, \mathrm{m}), 0.90(3 \mathrm{H}, \mathrm{t}, 7.3), 0.87(3 \mathrm{H}, \mathrm{d}, J=6.8 \mathrm{~Hz}), 0.82(3 \mathrm{H}, \mathrm{d}, J=6.8$ $\mathrm{Hz}) ;{ }^{13} \mathrm{C}$ NMR $\left(126 \mathrm{MHz}, \mathrm{CDCl}_{3}\right) \delta \mathrm{C} 178.1,155.9,143.5,128.7,128.3,117.0,108.2,64.8$, 57.3, 55.2, 54.9, 43.0, 41.8, 38.7, 28.9, 19.5, 18.7, 18.3, 14.5; HRMS (APCI) m/z: $[\mathrm{M}+\mathrm{H}]^{+}$ calculated for $\left[\mathrm{C}_{19} \mathrm{H}_{30} \mathrm{NO}_{3}\right]^{+} 320.2226$, found 320.2228; IR (neat) $\tilde{v}=3302,3253,3068,2958$, 2937, 29.05, 2872, 2837, 1717, 1619, 1591, 1552, 1482, 1467, 1441, 1388, 1372, 1353, 1335, 1324, 1297, 1284, 1262, 1225, 1184, 1167, 1151, 1132, 1119, 1081, 1057, 1041, 1017, 993, 966,

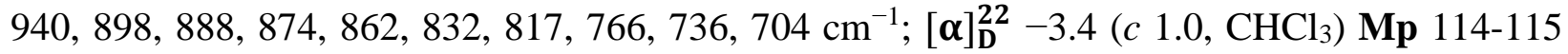
${ }^{\circ} \mathrm{C}$.

(R)-N-((S)-1-Hydroxy-3-methylbutan-2-yl)-4-methoxy-2-(prop-2-yn-1-yl)-2,3-dihydro-1Hindene-2-carboxamide (17d):
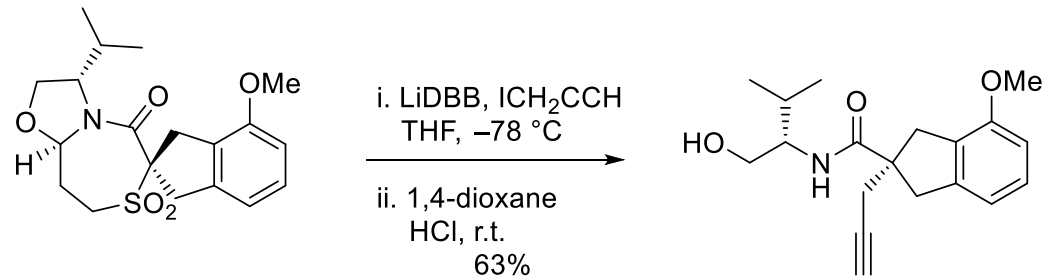

Amide 17d was synthesised according to the example procedure using LiDBB ( $0.4 \mathrm{M}, 690 \mu 1$, $0.28 \mathrm{mmol}, 2.1$ equiv), spirocycle $13 \mathbf{a}(50 \mathrm{mg}, 0.13 \mathrm{mmol}, 1$ equiv), degassed dry THF ( $5 \mathrm{ml})$, propargyl bromide ( $80 \%$ in PhMe, $50 \mu \mathrm{l}, 0.53 \mathrm{mmol}, 4$ equiv), which had been passed through a column of activated, basic, Brockmann I aluminium oxide, 1,4-dioxane $(5 \mathrm{ml})$ and $1 \mathrm{M} \mathrm{HCl}_{(\mathrm{aq})}$ $(2.5 \mathrm{ml})$. EtOAc $(3 \times 20 \mathrm{ml})$ was employed for the aqueous work up with combined organic extracts dried over $\mathrm{Na}_{2} \mathrm{SO}_{4}$, filtered, and concentrated to afford a yellow oil which was purified by column chromatography (15 $\mathrm{g} \mathrm{SiO}_{2}, 40-60 \%$ EtOAc in hexanes). Amide 17d was isolated as a slightly yellow oil $(26 \mathrm{mg}, 63 \%) .{ }^{1} \mathbf{H}$ NMR $\left(500 \mathrm{MHz}, \mathrm{CDCl}_{3}\right) \delta \mathrm{H} 7.16(1 \mathrm{H}, \mathrm{dd}, J=8.2,7.6$ 
$\mathrm{Hz}), 6.83(1 \mathrm{H}, J=7.6 \mathrm{~Hz}), 6.70(1 \mathrm{H}, \mathrm{d}, J=8.2 \mathrm{~Hz}), 6.04\left(1 \mathrm{H}, \mathrm{d}, J=7.9 \mathrm{~Hz}, \mathrm{D}_{2} \mathrm{O}\right.$ exch. $), 3.82$ $(3 \mathrm{H}, \mathrm{s}), 3.78(1 \mathrm{H}, \mathrm{m}), 3.69(1 \mathrm{H}, \mathrm{dd}, J=11.2,2.9 \mathrm{~Hz}), 3.62(1 \mathrm{H}, \mathrm{dd}, J=11.2,6.3 \mathrm{~Hz}), 3.20(1 \mathrm{H}$, d, $J=16.2 \mathrm{~Hz}), 3.23(1 \mathrm{H}, \mathrm{d}, J=16.2 \mathrm{~Hz}), 3.16(1 \mathrm{H}, \mathrm{d}, J=16.3 \mathrm{~Hz}), 3.07(1 \mathrm{H}, \mathrm{d}, J=16.2 \mathrm{~Hz})$, $2.59(2 \mathrm{H}, \mathrm{m}), 2.13(1 \mathrm{H}, \mathrm{t}, J=2.3 \mathrm{~Hz}), 1.86(1 \mathrm{H}, \mathrm{dqq}, J=6.9,6.7,6.7 \mathrm{~Hz}), 0.91(1 \mathrm{H}, \mathrm{d}, J=6.7$ $\mathrm{Hz}), 0.86(1 \mathrm{H}, \mathrm{d}, J=6.9 \mathrm{~Hz}) ;{ }^{13} \mathrm{C}$ NMR $\left(126 \mathrm{MHz}, \mathrm{CDCl}_{3}\right) \delta \mathrm{C} 176.3,156.2,142.7,128.6$, 128.0, 117.2, 108.4, 81.9, 71.6, 64.2, 57.4, 55.2, 53.4, 42.4, 38.2, 29.0, 27.3, 19.5, 18.3; HRMS (ESI) $\mathbf{~ m} / \mathbf{z}:[\mathrm{M}+\mathrm{Na}]^{+}$calculated for $\left[\mathrm{C}_{19} \mathrm{H}_{25} \mathrm{NO}_{3} \mathrm{Na}\right]^{+} 338.1727$, found 338.1717; IR (neat) $\tilde{v}=$ 3380, 3299, 2960, 2937, 2874, 2838, 1720, 1641, 1591, 1523, 1482, 1468, 1440, 1389, 1369, $1335,1264,1180,1150,1110,1070,976,939,911,769,735,704,638,525 \mathrm{~cm}^{-1} ;[\alpha]_{\mathrm{D}}^{22}-3.2(c$ $\left.1.0, \mathrm{CHCl}_{3}\right)$.

\section{(R)-2-Benzyl- $N$-((S)-1-hydroxy-3-methylbutan-2-yl)-4-methoxy-2,3-dihydro-1 $H$-indene-2- carboxamide (17e):}

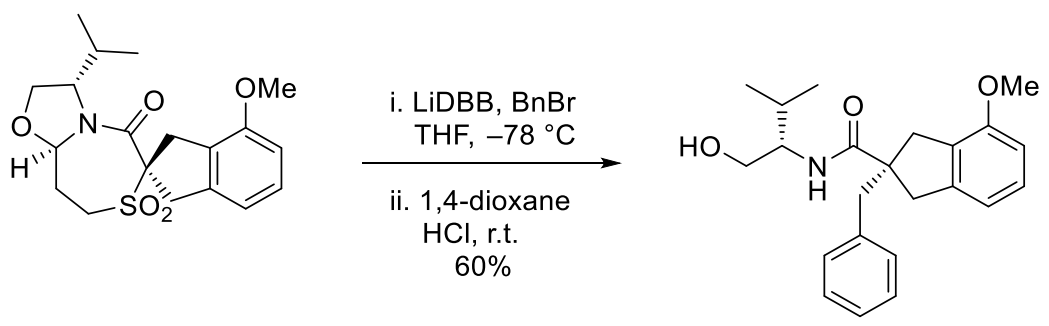

Amide 17e was synthesised according to the example procedure using LiDBB $(0.4 \mathrm{M}, 1.65 \mathrm{ml}$, $0.664 \mathrm{mmol}, 2.1$ equiv), spirocycle 13a (115 $\mathrm{mg}, 0.316 \mathrm{mmol}, 1$ equiv), degassed dry THF (6 $\mathrm{ml}$ ), benzyl bromide (150 $\mu \mathrm{l}, 1.26 \mathrm{mmol}, 4$ equiv), which had been passed through a column of activated, basic, Brockmann I aluminium oxide, 1,4-dioxane $(6 \mathrm{ml})$ and $1 \mathrm{M} \mathrm{HCl}_{(\mathrm{aq})}(2.5 \mathrm{ml})$. EtOAc $(3 \times 20 \mathrm{ml})$ was employed for the aqueous work up with combined organic extracts dried over $\mathrm{Na}_{2} \mathrm{SO}_{4}$, filtered, and concentrated to afford a yellow oil which was purified by column chromatography (15 $\mathrm{g} \mathrm{SiO}_{2}, 40-60 \%$ EtOAc in hexanes). Amide 17e was isolated as a white solid $(69 \mathrm{mg}, 60 \%) .{ }^{1} \mathbf{H}$ NMR $\left(500 \mathrm{MHz}, \mathrm{CDCl}_{3}\right) \delta \mathrm{H} 7.22-7.33(5 \mathrm{H}, \mathrm{m}), 7.19(1 \mathrm{H}, \mathrm{t}, J=7.8$ $\mathrm{Hz}), 6.88(1 \mathrm{H}, \mathrm{d}, J=7.4 \mathrm{~Hz}), 6.73(1 \mathrm{H}, \mathrm{d}, J=8.2 \mathrm{~Hz}), 5.79\left(1 \mathrm{H}, \mathrm{d}, J=7.7 \mathrm{~Hz}, \mathrm{D}_{2} \mathrm{O}\right.$ exch.), 3.86 $(3 \mathrm{H}, \mathrm{s}), 3.64(1 \mathrm{H}, \mathrm{m}), 3.52(2 \mathrm{H}, \mathrm{m}), 3.34(1 \mathrm{H}, \mathrm{d}, J=15.8 \mathrm{~Hz}), 3.17(1 \mathrm{H}, \mathrm{d}, J=13.3 \mathrm{~Hz}), 3.14$ $(1 \mathrm{H}, \mathrm{d}, J=14.8 \mathrm{~Hz}), 3.10(1 \mathrm{H}, \mathrm{d}, J=16.2 \mathrm{~Hz}), 3.05(1 \mathrm{H}, \mathrm{d}, J=15.9 \mathrm{~Hz}), 2.98(1 \mathrm{H}, \mathrm{d}, J=13.4$ $\mathrm{Hz}), 2.40\left(1 \mathrm{H}\right.$, br. s, $\mathrm{D}_{2} \mathrm{O}$ exch. $), 1.70(1 \mathrm{H}, \mathrm{m}), 0.76(3 \mathrm{H}, \mathrm{d}, J=6.8 \mathrm{~Hz}), 0.67(3 \mathrm{H}, \mathrm{d}, J=6.8 \mathrm{~Hz})$; ${ }^{13}$ C NMR $\left(126 \mathrm{MHz}, \mathrm{CDCl}_{3}\right) \delta \mathrm{C} 176.8,156.0,143.4,138.1,130.1,128.5,128.2,128.2,126.7$, 117.2, 108.4, 64.1, 57.4, 56.8, 55.2, 43.6, 43.3, 37.3, 28.9, 19.3, 18.2; HRMS (APCI) m/z: $[\mathrm{M}+\mathrm{H}]^{+}$calculated for $\left[\mathrm{C}_{23} \mathrm{H}_{30} \mathrm{NO}_{3}\right]^{+} 368.22267$, found 368.2231; IR (neat) $\tilde{v}=3421,3303$, 3254, 3067, 3029, 2957, 2933, 2901, 2873, 2833, 1622, 1591, 1520, 1497, 1483, 1470, 1455, 1443, 1388, 1370, 1354, 1334, 1300, 1263, 1225, 1181, 1165, 1150, 1111, 1086, 1070, 1048, $1029,998,966,942,923,984,881,835,819,764,735,701,674 \mathrm{~cm}^{-1} ;[\boldsymbol{\alpha}]_{\mathbf{D}}^{22}-2.6(c 1.0$, $\left.\mathrm{CHCl}_{3}\right) ; \mathrm{Mp} 146-147^{\circ} \mathrm{C}$. 


\section{(R)-2-Allyl- $N$-((S)-1-hydroxy-3-methylbutan-2-yl)-4-methoxy-2,3-dihydro-1H-indene-2- carbox amide (17f):}
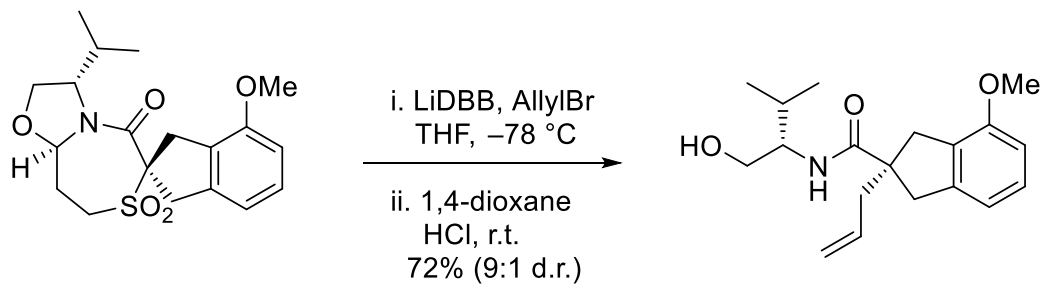

Amide 17f was synthesised according to the example procedure using LiDBB ( $0.4 \mathrm{M}, 3.3 \mathrm{ml}, 1.3$ mmol, 2.1 equiv), spirocycle 13a ( $224 \mathrm{mg}, 0.590 \mathrm{mmol}, 1$ equiv), degassed dry THF (13 ml), allyl bromide ( $205 \mu \mathrm{l}, 2.36 \mathrm{mmol}, 4$ equiv), which had been passed through a column of activated, basic, Brockmann I aluminium oxide, 1,4-dioxane $(8 \mathrm{ml})$ and $1 \mathrm{M} \mathrm{HCl}_{(\mathrm{aq})}(4 \mathrm{ml})$. EtOAc $(3 \times 30 \mathrm{ml})$ was employed for the aqueous work up with combined organic extracts dried over $\mathrm{Na}_{2} \mathrm{SO}_{4}$, filtered, and concentrated to afford a yellow oil which was purified by column chromatography (20 $\mathrm{g} \mathrm{SiO}_{2}, 40-60 \%$ EtOAc in hexanes). Amide 17f was isolated as a colourless oil $(135 \mathrm{mg}, 72 \%) .{ }^{1} \mathbf{H}$ NMR $\left(500 \mathrm{MHz}, \mathrm{CDCl}_{3}\right) \delta \mathrm{H} 7.15(1 \mathrm{H}, \mathrm{dd}, J=8.2,7.5 \mathrm{~Hz}), 6.82(1 \mathrm{H}, J=$ $7.5 \mathrm{~Hz}), 6.69(1 \mathrm{H}, \mathrm{d}, J=8.2 \mathrm{~Hz}), 5.82(1 \mathrm{H}, \mathrm{m}), 5.71\left(1 \mathrm{H}, \mathrm{d}, J=7.5 \mathrm{~Hz}, \mathrm{D}_{2} \mathrm{O}\right.$ exch. $), 5.09(2 \mathrm{H}$, $\mathrm{m}), 3.82(3 \mathrm{H}, \mathrm{s}), 3.73(1 \mathrm{H}, \mathrm{m}), 3.59-3.67(2 \mathrm{H}, \mathrm{m}), 3.35(1 \mathrm{H}, \mathrm{d}, J=16.2 \mathrm{~Hz}), 3.19(1 \mathrm{H}, \mathrm{d}, J=$ $16.2 \mathrm{~Hz}), 2.99(1 \mathrm{H}, \mathrm{d}, J=16.2 \mathrm{~Hz}), 2.99(1 \mathrm{H}, \mathrm{d}, J=16.2 \mathrm{~Hz}), 2.64\left(1 \mathrm{H}\right.$, br. s, $\mathrm{D}_{2} \mathrm{O}$ exch.), 2.52 $(1 \mathrm{H}, \mathrm{dd}, J=14.0,7.3 \mathrm{~Hz}), 2.43(1 \mathrm{H}, \mathrm{dd}, J=14.0,7.2 \mathrm{~Hz}), 1.83(1 \mathrm{H}, \mathrm{m}), 0.88(3 \mathrm{H}, \mathrm{d}, J=6.7$ $\mathrm{Hz}), 0.83(3 \mathrm{H}, \mathrm{d}, J=6.9 \mathrm{~Hz}) ;{ }^{13} \mathrm{C}$ NMR $\left(126 \mathrm{MHz}, \mathrm{CDCl}_{3}\right) \delta \mathrm{C} 177.4,156.0,143.3,134.3,128.4$ (2C), 118.4, 117.1, 108.3, 64.5, 57.3, 55.2, 54.2, 42.9, 42.5, 39.0, 29.0, 19.6, 18.4; HRMS (ESI) $\mathbf{m} / \mathbf{z}$ : $[\mathrm{M}+\mathrm{Na}]^{+}$calculated for $\left[\mathrm{C}_{19} \mathrm{H}_{28} \mathrm{NO}_{3}\right]^{+} 318.2062$, found 318.2064; IR (neat) $\tilde{v}=33012$, 2157, 3074, 3000, 2960, 2937, 2905, 2873, 2836, 1621, 1591, 1551, 1482, 1468, 1449, 1388, 1372, 1353, 1336, 1305, 1263, 1223, 1183, 1167, 1149, 1102, 1083, 1057, 1130,993, 966, 919 , $886,862,834,818,765,736,704,655 \mathrm{~cm}^{-1}$; $[\boldsymbol{\alpha}]_{\mathbf{D}}^{22}-1.6\left(c 1.0, \mathrm{CHCl}_{3}\right) ; \mathbf{M p ~ 1 0 2 - 1 0 3 ~}{ }^{\circ} \mathrm{C}$.

\section{$(R)-N$-( (S)-1-Hydroxy-3-methylbutan-2-yl)-2-methyl-4-phenyl-2,3-dihydro-1H-indene-2- carboxamide (17g):}
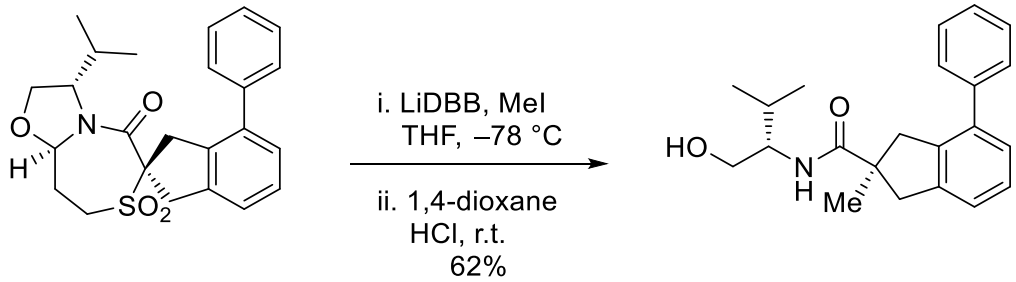

Amide 17g was synthesised according to the example procedure using LiDBB (0.4 M, added until colour persisted), spirocycle $13 f(43 \mathrm{mg}, 0.10 \mathrm{mmol}, 1$ equiv), degassed dry THF (5 ml), iodomethane $(25 \mu \mathrm{l}, 0.40 \mathrm{mmol}, 4$ equiv), which had been passed through a column of activated, basic, Brockmann I aluminium oxide, 1,4-dioxane $(10 \mathrm{ml})$ and $1 \mathrm{M} \mathrm{HCl}_{(\mathrm{aq})}(5 \mathrm{ml})$. EtOAc $(3 \times$ $20 \mathrm{ml}$ ) was employed for the aqueous work up with combined organic extracts dried over $\mathrm{Na}_{2} \mathrm{SO}_{4}$, filtered, and concentrated to afford a yellow oil which was purified by column chromatography (8 $\mathrm{g} \mathrm{SiO}_{2}, 10-60 \%$ EtOAc in hexanes). Amide $\mathbf{1 7} \mathbf{g}$ was isolated as a slightly yellow solid $(21 \mathrm{mg}, 62 \%) .{ }^{1} \mathbf{H}$ NMR $\left(500 \mathrm{MHz}, \mathrm{CDCl}_{3}\right) \delta \mathrm{H} 7.42(4 \mathrm{H}, \mathrm{m}), 7.34(1 \mathrm{H}, \mathrm{m}), 2.27$ $(1 \mathrm{H}, \mathrm{m}), 7.22(2 \mathrm{H}, \mathrm{m}), 5.71\left(1 \mathrm{H}, \mathrm{d}, J=7.1 \mathrm{~Hz}, \mathrm{D}_{2} \mathrm{O}\right.$ exch. $), 3.59-3.73(2 \mathrm{H}, \mathrm{m}), 3.6(1 \mathrm{H}, \mathrm{m})$, $3.49(1 \mathrm{H}, \mathrm{d}, J=16.0 \mathrm{~Hz}), 3.48(1 \mathrm{H}, \mathrm{d}, J=15.6 \mathrm{~Hz}), 2.94(1 \mathrm{H}, \mathrm{d}, J=15.4 \mathrm{~Hz}), 2.92(1 \mathrm{H}, \mathrm{d}, J=$ 
$16.0 \mathrm{~Hz}),\left(1 \mathrm{H}\right.$, broad s, $\mathrm{D}_{2} \mathrm{O}$ exch. $), 1.84(1 \mathrm{H}, \mathrm{d}$ of septets, $J=6.8,6.8 \mathrm{~Hz}), 1.37(3 \mathrm{H}, \mathrm{s}), 0.88$ $(3 \mathrm{H}, \mathrm{d}, J=6.8 \mathrm{~Hz}), 0.81(3 \mathrm{H}, \mathrm{d}, J=6.8 \mathrm{~Hz})$; HRMS $(\mathbf{E S I}) \mathbf{m} / \mathbf{z}:[\mathrm{M}+\mathrm{Na}]^{+}$calculated for $\left[\mathrm{C}_{22} \mathrm{H}_{28} \mathrm{NO}_{2}\right]^{+} 338.2115$, found 338.2118; ${ }^{13} \mathrm{C}$ NMR $\left(126 \mathrm{MHz}, \mathrm{CDCl}_{3}\right) \delta \mathrm{C} 178.7,142.3,140.7$, $139.1,138.8,128.5,128.4,127.4,127.3,127.1,123.8,64.6,57.3,50.5,44.8,44.0,29.0,25.1$, 19.6, 18.4; IR (neat) $\tilde{v}=3348,3058,2959,2928,2872,1638,1519,1465,1426,1386,1370$, 1312, 1265, 1142, 1072, 1027, 978, 920, 889, 789, 757, 736, 700, 670, 590, 569, 519, $444 \mathrm{~cm}^{-1}$; $[\boldsymbol{\alpha}]_{\mathbf{D}}^{\mathbf{2 2}}-4.1\left(c 1.0, \mathrm{CHCl}_{3}\right) ; \mathbf{M p} 140-142{ }^{\circ} \mathrm{C}$.

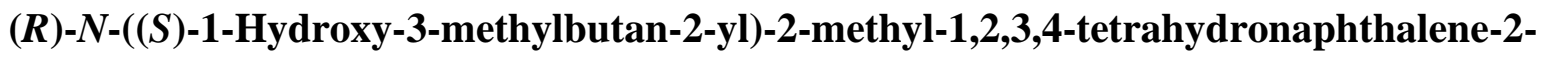
carboxamide (17h):
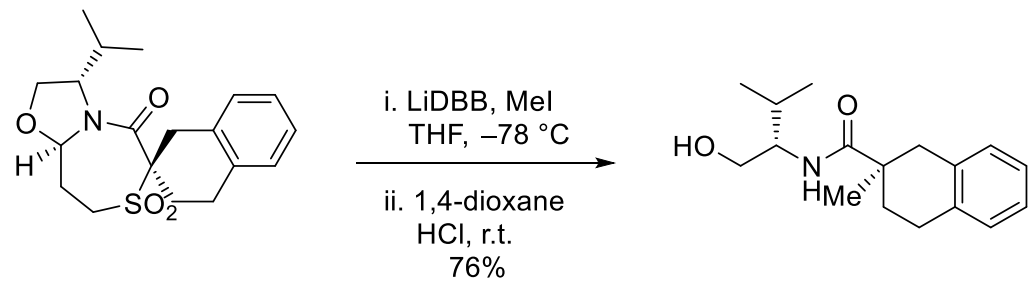

Amide 17h was synthesised according to the example procedure using LiDBB $(0.4 \mathrm{M}, 500 \mu \mathrm{l}$, $0.20 \mathrm{mmol}, 2.1$ equiv), spirocycle $13 \mathrm{e}$ ( $35 \mathrm{mg}, 0.10 \mathrm{mmol}, 1$ equiv), degassed dry THF (24 ml), methyl iodide ( $60 \mu \mathrm{l}, 1.0 \mathrm{mmol}, 10$ equiv), which had been passed through a column of activated, basic, Brockmann I aluminium oxide, 1,4-dioxane $(10 \mathrm{ml})$ and $1 \mathrm{M} \mathrm{HCl}_{(\mathrm{aq})}(5 \mathrm{ml})$. EtOAc $(3 \times$ $20 \mathrm{ml}$ ) was employed for the aqueous work up with combined organic extracts dried over $\mathrm{Na}_{2} \mathrm{SO}_{4}$, filtered, and concentrated to afford a colourless residue which was purified by column chromatography (12 $\mathrm{g} \mathrm{SiO}_{2}, 40-50 \%$ EtOAc in hexanes). Amide $\mathbf{1 7 h}$ was isolated as a colourless oil (20 mg, 76\%). ${ }^{1} \mathbf{H}$ NMR $\left(500 \mathrm{MHz}, \mathrm{CDCl}_{3}\right) \delta \mathrm{H} 7.12(4 \mathrm{H}, \mathrm{m}), 5.73(1 \mathrm{H}, \mathrm{d}, J=6.6$ $\mathrm{Hz}, \mathrm{D}_{2} \mathrm{O}$ exch.), $3.71(1 \mathrm{H}$, ddd, $J=7.2,6.7,3.5 \mathrm{~Hz}), 3.649(1 \mathrm{H}, \mathrm{dd}, J=11.0,3.5 \mathrm{~Hz}), 3.56(1 \mathrm{H}$, $\mathrm{dd}, J=11.0,6.7 \mathrm{~Hz}), 3.07(1 \mathrm{H}, \mathrm{d}, J=17.5 \mathrm{~Hz}), 2.77-2.88(2 \mathrm{H}, \mathrm{m}), 2.62\left(1 \mathrm{H}\right.$, broad s, $\mathrm{D}_{2} \mathrm{O}$ exch), $2.22(1 \mathrm{H}, \mathrm{m}), 1.66-1.77(2 \mathrm{H}, \mathrm{m}), 1.33(3 \mathrm{H}, \mathrm{s}), 0.69(3 \mathrm{H}, \mathrm{d}, J=6.8 \mathrm{~Hz}), 0.60(3 \mathrm{H}, \mathrm{d}, J=$ $6.8 \mathrm{~Hz}) ;{ }^{13} \mathrm{C}$ NMR $\left(126 \mathrm{MHz}, \mathrm{CDCl}_{3}\right) \delta \mathrm{C} 178.3,135.8,134.3,129.1,128.8,126.4,126.2,65.0$, 57.2, 42.0, 39.1, 33.2, 28.7, 26.5, 25.9, 19.4, 17.7; HRMS (ESI) $\mathbf{~ m / z : ~}[\mathrm{M}+\mathrm{Na}]^{+}$calculated for $\left[\mathrm{C}_{17} \mathrm{H}_{25} \mathrm{O}_{2} \mathrm{NNa}\right]^{+} 298.1778$, found 298.1775; IR (neat) $\tilde{v}=3309,3046,3019,2960,2929,2878$, 2846, 2259, 1627, 1581, 1540, 1495, 1463, 1440, 1418, 1389, 1371, 1347, 1215m 1292, 1273, 1250, 1236, 1215, 1189, 1149, 1125, 1088, 1056, 1032, 1021, 998, 973, 958, 922, 910, 824, 799,

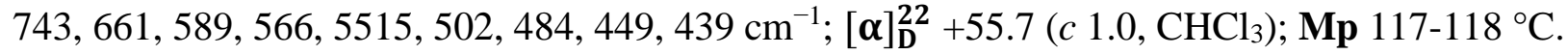

\section{(R)- $N$-((S)-1-Hydroxy-3-methylbutan-2-yl)-1-methyl-3-methylenecyclopentane-1-carbox amide (17i):}
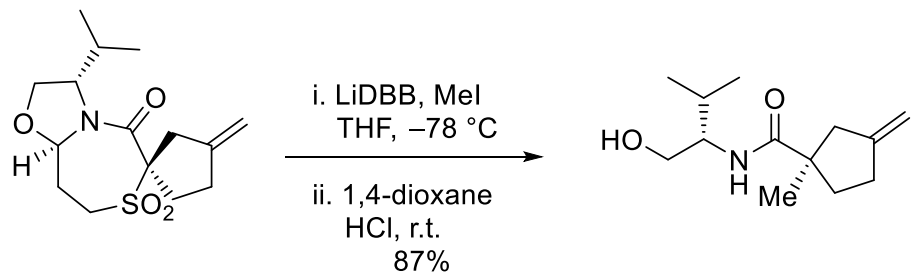

Amide 17i was synthesised according to the example procedure using LiDBB $(0.4 \mathrm{M}, 530 \mu 1$, $0.21 \mathrm{mmol}, 2.1$ equiv), spirocycle $\mathbf{1 3 d}$ ( $31 \mathrm{mg}, 0.10 \mathrm{mmol}, 1$ equiv), degassed dry THF (20 ml), methyl iodide ( $62 \mu 1,1.0 \mathrm{mmol}, 10$ equiv), which had been passed through a column of activated, 
basic, Brockmann I aluminium oxide, 1,4-dioxane $(10 \mathrm{ml})$ and $1 \mathrm{M} \mathrm{HCl}_{(\mathrm{aq})}(5 \mathrm{ml})$. EtOAc $(3 \times$ $20 \mathrm{ml}$ ) was employed for the aqueous work up with combined organic extracts dried over $\mathrm{Na}_{2} \mathrm{SO}_{4}$, filtered, and concentrated to afford a colourless residue which was purified by column chromatography (10 $\mathrm{g} \mathrm{SiO}_{2}, 50-60 \%$ EtOAc in hexanes). Amide 17f was isolated as a colourless oil $(20 \mathrm{mg}, 87 \%) .{ }^{1} \mathbf{H}$ NMR $\left(500 \mathrm{MHz}, \mathrm{CDCl}_{3}\right) \delta \mathrm{H} 5.79\left(1 \mathrm{H}, \mathrm{s}, \mathrm{D}_{2} \mathrm{O}\right.$ exch), $4.96(1 \mathrm{H}$, s), $4.89(1 \mathrm{H}, \mathrm{s}), 3.73(2 \mathrm{H}, \mathrm{m}), 3.64(1 \mathrm{H}, \mathrm{m}), 2.73(1 \mathrm{H}, \mathrm{d}, J=16.1 \mathrm{~Hz}), 2.67\left(1 \mathrm{H}, \mathrm{s}, \mathrm{D}_{2} \mathrm{O}\right.$ exch), $2.44(2 \mathrm{H}, \mathrm{m}), 2.26(1 \mathrm{H}, \mathrm{d}, J=16.0 \mathrm{~Hz}), 2.13(1 \mathrm{H}, \mathrm{dt}, J=12.6,8.3 \mathrm{~Hz}), 1.90(1 \mathrm{H}, \mathrm{d}$ of septets, $J$ $=6.8,6.8 \mathrm{~Hz}), 1.67(1 \mathrm{H}, \mathrm{dt}, J=12.7,7.3 \mathrm{~Hz}), 1.28(3 \mathrm{H}, \mathrm{s}), 0.96(3 \mathrm{H}, \mathrm{d}, J=6.8 \mathrm{~Hz}), 0.92(3 \mathrm{H}$, $\mathrm{d}, J=6.8 \mathrm{~Hz}) ;{ }^{13} \mathrm{C}$ NMR $\left(126 \mathrm{MHz}, \mathrm{CDCl}_{3}\right) \delta \mathrm{C} 178.7,150.4,107.1,64.5,57.1,49.7,44.6,37.1$, 30.5, 29.1, 24.2, 19.6, 18.6; HRMS (APCI) m/z: $[\mathrm{M}+\mathrm{H}]^{+}$calculated for $\left[\mathrm{C}_{13} \mathrm{H}_{24} \mathrm{O}_{2} \mathrm{~N}\right]^{+} 226.1801$, found 226.1806; IR (neat) $\tilde{v}=3351,3069,2961,2929,2873,1724,1636,1522,1464,1388$, 1370, 1304, 1267, 1228, 1174, 1127, 1072, 1034, 950, 925, 879, 734, 702, 609, 479, $423 \mathrm{~cm}^{-1}$; $[\boldsymbol{\alpha}]_{\mathrm{D}}^{22}+48.1\left(c 1.0, \mathrm{CHCl}_{3}\right)$.

5-(vinyloxy)pent-2-yne (19):

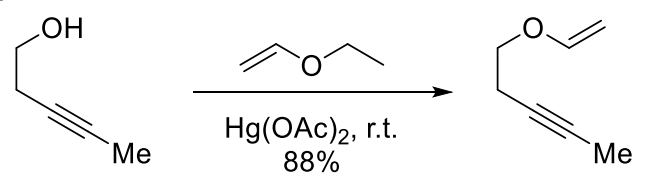

3-pentyn-1-ol (1.84 ml, $20.0 \mathrm{mmol}, 1$ equiv) and $\mathrm{Hg}(\mathrm{OAc})_{2}$ (319 mg, $1.0 \mathrm{mmol}, 0.05$ equiv) were dissolved in ethyl vinyl ether $(39.4 \mathrm{ml}, 400 \mathrm{mmol}, 20$ equiv) and left to stir at r.t. for 12 days. The reaction solution was then washed with sat. $\mathrm{NaHCO}_{3}(20 \mathrm{ml})$ and the organic phase dried over $\mathrm{Na}_{2} \mathrm{SO}_{4}$ and filtered. Excess ethyl vinyl ether by simple distillation. Ene-yne 19 was purified by fractional distillation $\left(45 \mathrm{mmHg}, 60-63{ }^{\circ} \mathrm{C}\right)$ and isolated as a clear colourless sweetsmelling liquid $(1.93 \mathrm{~g}, 88 \%) .{ }^{1} \mathbf{H}$ NMR $\left(500 \mathrm{MHz}, \mathrm{CDCl}_{3}\right) \delta \mathrm{H} 6.49(1 \mathrm{H}, \mathrm{dd}, J=14.4,6.6 \mathrm{~Hz})$, $4.22(1 \mathrm{H}, \mathrm{dd}, J=14.4,2.0 \mathrm{~Hz}), 4.04(1 \mathrm{H}, \mathrm{dd}, J=6.7,2.0 \mathrm{~Hz}), 3.78(2 \mathrm{H}, \mathrm{t}, J=7.0 \mathrm{~Hz}), 2.52(2 \mathrm{H}$, tq, $J=7.0,2.4 \mathrm{~Hz}), 1.81(3 \mathrm{H}, \mathrm{t}, J=2.5 \mathrm{~Hz}) ;{ }^{13} \mathbf{C ~ N M R}\left(126 \mathrm{MHz}, \mathrm{CDCl}_{3}\right) \delta \mathrm{C} 151.5,86.8,77.1$, 75.1, 66.5, 19.5, 3.5; HRMS (APCI) $\mathbf{m} / \mathbf{z}:[\mathrm{M}+\mathrm{H}]^{+}$calculated for $\left[\mathrm{C}_{7} \mathrm{H}_{11} \mathrm{O}_{1}\right]^{+} 111.0804$, found 111.0806; IR (neat) $\tilde{v}=3118,2944,2921,2879,2861,1637,1615,1423,1374,1340,1321$, 1290, 1197, 1152, 1079, 1018, 998, 963, 945, 816, $700 \mathrm{~cm}^{-1}$.

Dimethyl 4-methyl-2,3,5,7a-tetrahydrobenzofuran-6,7-dicarboxylate (20):

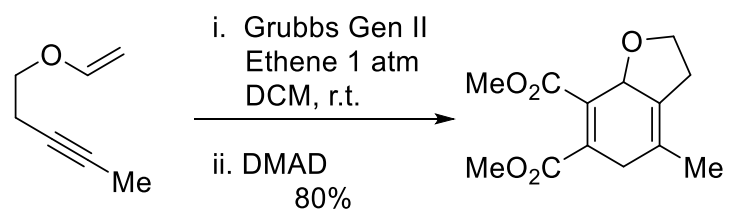

Ethylene was bubbled through a solution of ene-yne 19 (220 mg, $2.0 \mathrm{mmol}, 1$ equiv) in DCM (12 $\mathrm{ml})$ before Grubbs generation two catalyst $(17 \mathrm{mg}, 0.020 \mathrm{mmol}, 0.01$ equiv) was added as a solution in DCM (3 ml) via canula. The flask was then fitted with a balloon of ethylene and stirred at r.t overnight. Activated charcoal was added to the reaction and the solution filtered through a small pad of celite. The filtrate was transferred to a vial and freshly distilled dimethyl acetylenedicarboxylate $(0.98 \mathrm{ml}, 8.0 \mathrm{mmol}, 4$ equiv) added before the vial was sealed and the reaction left to still at r.t. overnight. Solvent was removed by rotary evaporator and the resulting residue purified by column chromatography $\left(24 \mathrm{~g} \mathrm{SiO}_{2}, 0-45 \% \mathrm{EtOAc}\right.$ in hexanes, $30 \mathrm{ml} / \mathrm{min}$, $15 \mathrm{~min}$ ) to afford dihydroarene $\mathbf{2 0}$ as a white solid (400 mg, 80\%). ${ }^{\mathbf{1}} \mathbf{H} \mathbf{~ N M R}$ (500 $\mathrm{MHz}$, 
$\left.\mathrm{CDCl}_{3}\right) \delta \mathrm{H} 4.77(1 \mathrm{H}, \mathrm{m}), 4.00(2 \mathrm{H}, \mathrm{m}), 3.86(3 \mathrm{H}, \mathrm{s}), 3.78(3 \mathrm{H}, \mathrm{s}), 3.11(1 \mathrm{H}, \mathrm{dd}, J=22.0,5.6$ $\mathrm{Hz}), 2.90(1 \mathrm{H}, \mathrm{dd}, J=22.1,9.7 \mathrm{~Hz}), 2.64(1 \mathrm{H}, \mathrm{m}), 2.54(1 \mathrm{H}, \mathrm{m}), 1.79(3 \mathrm{H}, \mathrm{s}) ;{ }^{13} \mathrm{C}$ NMR $(126$ $\left.\mathrm{MHz}, \mathrm{CDCl}_{3}\right) \delta \mathrm{C} 167.6,166.4,137.8,131.0,129.3,122.2,74.5,66.9,52.4$ (2C), 34.0, 27.7, 18.9; HRMS (ESI) m/z: $[\mathrm{M}+\mathrm{Na}]^{+}$calculated for $\left[\mathrm{C}_{13} \mathrm{H}_{16} \mathrm{O}_{5} \mathrm{Na}\right]^{+} 275.0890$, found 275.0881 ; IR (neat) $\tilde{v}=2952,2913,2859,2813,1721,1648,1434,1385,1350,1259,1212,1147,1114$, 1086, 1013, 977, 956, 913, 844, 788, 763, $681 \mathrm{~cm}^{-1}$; Mp 107-109 ${ }^{\circ} \mathrm{C}$.

\section{Dimethyl 4-methyl-2,3-dihydrobenzofuran-6,7-dicarboxylate (21):}

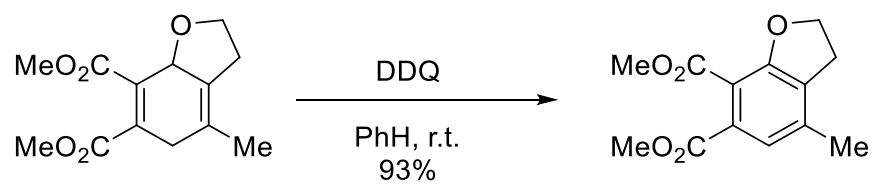

DDQ (1.24 g, $5.45 \mathrm{mmol}, 1$ equiv) was added to a solution of dimethyl dihydroarene $\mathbf{2 0}$ (1.38 g, $5.45 \mathrm{mmol}, 1$ equiv) in benzene ( $36 \mathrm{ml})$. The solution was stirred at r.t. for 1 hour then filtered through celite. The filtrate was concentrated to afford a solid residue which was purified by column chromatography ( $24 \mathrm{~g} \mathrm{SiO}_{2}, 20-60 \%$ EtOAc in hexanes, $30 \mathrm{ml} / \mathrm{min}, 15 \mathrm{~min}$ ) to afford dihydrobenzofuran 21 as an off white solid (1.273 g, 93\%). ${ }^{1} \mathbf{H}$ NMR $\left(500 \mathrm{MHz}, \mathrm{CDCl}_{3}\right) \delta \mathrm{H}$ $7.22(1 \mathrm{H}, \mathrm{s}), 4.70(2 \mathrm{H}, \mathrm{t}, J=8.7 \mathrm{~Hz}), 3.90(3 \mathrm{H}, \mathrm{s}), 3.85(3 \mathrm{H}, \mathrm{s}), 3.16(2 \mathrm{H}, \mathrm{t}, J=8.7 \mathrm{~Hz}), 2.28$ $(3 \mathrm{H}, \mathrm{s}) ;{ }^{13} \mathrm{C}$ NMR $\left(126 \mathrm{MHz}, \mathrm{CDCl}_{3}\right) \delta \mathrm{C} 167.0,167.0,157.7,136.4,131.7,129.3,123.4,113.4$, 72.2, 52.6, 52.5, 28.5, 19.0; HRMS (ESI) $\mathbf{m} / \mathbf{z}:[\mathrm{M}+\mathrm{Na}]^{+}$calculated for $\left[\mathrm{C}_{13} \mathrm{H}_{14} \mathrm{O}_{5} \mathrm{Na}\right]^{+}$ 273.0733, found 273.0725. IR (neat) $\tilde{v}=3044,3004,2957,2921,2849,1715,1615,1589,1483$, 1456, 1429, 1411, 1386, 1367, 1348, 1280, 1226, 1191, 1174, 1142, 1066, 1023, 1004, 978, 937, $928,864,808,786,773,736,701 \mathrm{~cm}^{-1}$; Mp $104-105^{\circ} \mathrm{C}$.

\section{One-Pot Procedure:}

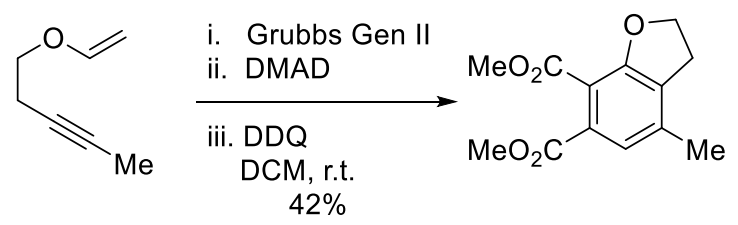

Grubbs generation two catalyst $(68 \mathrm{mg}, 0.080 \mathrm{mmol}, 0.04$ equiv) was added, as a solution in DCM (2 ml), via canula to a solution of ene-yne 19 (220 mg, $2.0 \mathrm{mmol}, 1$ equiv) in DCM (8 ml) under an atmosphere for argon. The reaction was stirred at r.t. for 14 hours at which point freshly distilled dimethyl acetylenedicarboxylate $(0.98 \mathrm{ml}, 8.0 \mathrm{mmol}$, 4 equiv) was added and the resulting solution allowed to stir at r.t. for 24 hours. DDQ (1.24 g, $5.45 \mathrm{mmol}, 1$ equiv) was then added and the reaction stirred for an additional 3 hours. At this point volatiles were removed under reduced pressure and the resulting black residue subjected to purification by column chromatorgraphy (30 $\mathrm{g} \mathrm{SiO}_{2}, 25 \%$ EtOAc in hexanes). Fractions in interest were combined and concentrated to afford a solid which was taken up in a small volume of DCM and filtered through celite to remove remaining 2,3-dichloro-5,6-dicyano hydroquinone. Concentration of the filtrate provided dihydrobenzofuran 21 as a brown solid (210 $\mathrm{mg}, 42 \%)$. 
(4-Methyl-2,3-dihydrobenzofuran-6,7-diyl)dimethanol (S12):

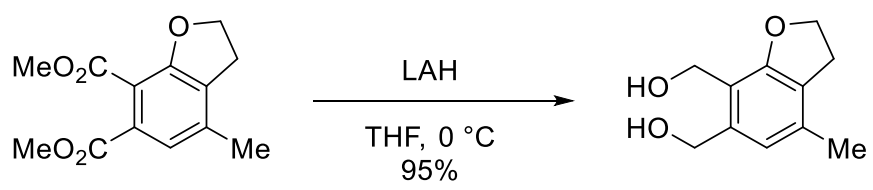

LAH (141 mg, $3.72 \mathrm{mmol}, 3$ equiv) was added, in small portions, to a solution of dihydrobenzofuran 21 (310 mg, $1.24 \mathrm{mmol}, 1$ equiv) in dry THF $(20 \mathrm{ml})$, under argon at $0{ }^{\circ} \mathrm{C}$. The reaction was left to stir at $0{ }^{\circ} \mathrm{C}$ for $70 \mathrm{~min}$. The reaction was then carefully quenched with water $(0.14 \mathrm{ml})$ and $15 \% \mathrm{KOH}_{(\mathrm{aq})}(0.14 \mathrm{ml})$ followed by a second portion of water $(0.42 \mathrm{ml})$. The solution was warmed to r.t. and left to stir vigorously for $45 \mathrm{~min}$ at which point a white solid had formed. The solution was dried with $\mathrm{Na}_{2} \mathrm{SO}_{4}$ and flirted through a pad of celite. The filtrate was concentrated to afford diol $\mathbf{S 1 2}$ as a white solid (229 mg, 95\%). ${ }^{1} \mathbf{H}$ NMR (500 MHz, DMSO$\left.d_{6}\right) \delta \mathrm{H} 6.71(1 \mathrm{H}, \mathrm{s}), 5.01\left(1 \mathrm{H}, \mathrm{t}, J=5.5 \mathrm{~Hz}, \mathrm{D}_{2} \mathrm{O}\right.$ exch. $), 4.69\left(1 \mathrm{H}, \mathrm{t}, J=5.4 \mathrm{~Hz}, \mathrm{D}_{2} \mathrm{O}\right.$ exch. $), 4.53$ $(2 \mathrm{H}, \mathrm{d}, J=5.4 \mathrm{~Hz}), 4.52(2 \mathrm{H}, \mathrm{t}, J=8.6 \mathrm{~Hz}), 4.43(2 \mathrm{H}, \mathrm{d}, J=5.4 \mathrm{~Hz}), 3.08(2 \mathrm{H}, \mathrm{t}, J=8.6 \mathrm{~Hz})$, $2.81(3 \mathrm{H}, \mathrm{s}) ;{ }^{1} \mathbf{H}$ NMR $\left(500 \mathrm{MHz}, \mathrm{CDCl}_{3}\right) \delta \mathrm{H} 6.68(1 \mathrm{H}, \mathrm{s}), 4.76(2 \mathrm{H}, \mathrm{s}), 4.67(2 \mathrm{H}, \mathrm{s}), 4.61(2 \mathrm{H}$, t, $J=8.7 \mathrm{~Hz}), 3.13(2 \mathrm{H}, \mathrm{t}, J=8.7 \mathrm{~Hz}), 2.63\left(2 \mathrm{H}\right.$, broad s, $\mathrm{D}_{2} \mathrm{O}$ exch. $), 2.23(3 \mathrm{H}, \mathrm{s}) ;{ }^{13} \mathbf{C}$ NMR $\left(126 \mathrm{MHz}, \mathrm{DMSO}-d_{6}\right) \delta \mathrm{C} 158.2,141.5,133.1,124.9,121.1,118.2,71.0,61.2,54.7,28.7,19.1$; ${ }^{13} \mathrm{C}$ NMR $\left(126 \mathrm{MHz}, \mathrm{CDCl}_{3}\right) \delta \mathrm{C} 158.6,139.7,134.5,126.2,122.9,118.3,71.4,64.1,56.9,28.9$, 18.8; HRMS (ESI) $\mathbf{m} / \mathbf{z}:[\mathrm{M}+\mathrm{Na}]^{+}$calculated for $\left[\mathrm{C}_{11} \mathrm{H}_{14} \mathrm{O}_{3} \mathrm{Na}\right]^{+} 217.0835$, found 217.0831. IR (neat) $\tilde{v}=3315,3238,2960,2915,1625,1595,1477,1445,1411,1371,1356,1328,1278,1256$, $1201,1082,1060,1027,1000,949,871,847,761,726,691 \mathrm{~cm}^{-1} ; \mathbf{M p} 123-124{ }^{\circ} \mathrm{C}$

\section{6,7-Bis(bromomethyl)-4-methyl-2,3-dihydrobenzofuran (8):}

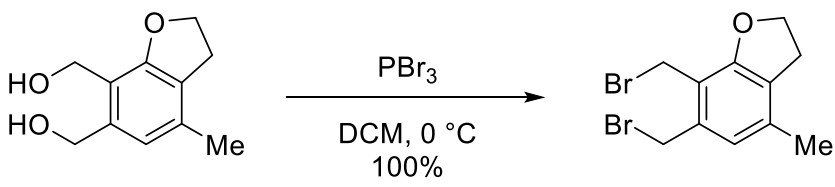

Phosphorus tribromide ( $51 \mu 1,0.54 \mathrm{mmol}, 1$ equiv) was added to a solution of diol $\mathbf{S 1 2}$ (104 $\mathrm{mg}$, $0.535 \mathrm{mmol}, 1$ equiv) in dry DCM $(10 \mathrm{ml})$ under argon at $0{ }^{\circ} \mathrm{C}$. The reaction was left to stir at 0 ${ }^{\circ} \mathrm{C}$ for 6 hours then quenched with sat. $\mathrm{NaHCO}_{3}(3 \mathrm{ml})$ and stirred at $0{ }^{\circ} \mathrm{C}$ for 5 min before being diluted with water $(7 \mathrm{ml})$. The phases were separated, and the aqueous phase extracted with DCM $(1 \times 15 \mathrm{ml})$. Combined organic extracts were dried over $\mathrm{Na}_{2} \mathrm{SO}_{4}$, filtered, and concentrated to afford dibromide 8 as a slightly off-white solid (172 mg, 100\%). ${ }^{1} \mathbf{H}$ NMR (500 MHz, $\left.\mathrm{CDCl}_{3}\right) \delta \mathrm{H} 6.70(1 \mathrm{H}, \mathrm{s}), 4.69(2 \mathrm{H}, \mathrm{s}), 4.67(2 \mathrm{H}, \mathrm{t}, J=8.6 \mathrm{~Hz}), 4.60(2 \mathrm{H}, \mathrm{s}), 3.13(2 \mathrm{H}, \mathrm{t}, J=8.6$ $\mathrm{Hz}), 2.22(3 \mathrm{H}, \mathrm{s}) ;{ }^{13} \mathrm{C}$ NMR $\left(126 \mathrm{MHz}, \mathrm{CDCl}_{3}\right) \delta \mathrm{C} 159.1,136.1,135.7,127.5,124.2,115.6$, 71.9, 30.4, 28.9, 24.4, 18.9; LRMS (CI) m/z: 240.9 (M-Br, 100.0), 238.9 (M-Br, 100.0), 195.1 (16.1), 161.1 (18.7), 160.1 (85.1); IR (neat) $\tilde{v}=3028,2972,2915,2853,1723,1622,1585,1478$, 1450, 1439, 1412, 1379, 1334, 1291, 1263, 1244, 1221, 1149, 1116, 1088, 1040, 999, 976, 911 , $864,824,737,676 \mathrm{~cm}^{-1} ; \mathbf{M p ~} 139-140{ }^{\circ} \mathrm{C}$. 
(3'S,7R,9a' $R$ )-3'-Isopropyl-4-methyl-2,2',3,3',6,8,9',9a'-octahydro-5' $H, 8^{\prime} H$-spiro[indeno[4,5b]furan-7,6'-oxazolo[3,2-d][1,4]thiazepin]-5'-one $7^{\prime}, 7^{\prime}$-dioxide (7):
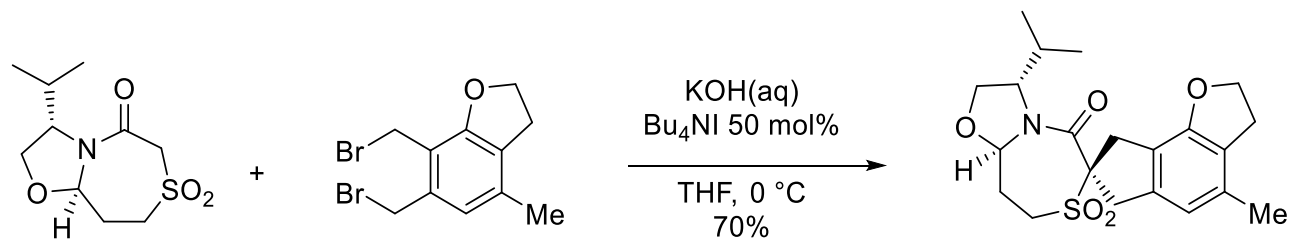

$\mathrm{KOH}_{(\mathrm{aq})}(50 \mathrm{wt} \%, 2 \mathrm{ml})$ was added drop-wise to a solution of sulfone $6(80 \mathrm{mg}, 0.32 \mathrm{mmol}, 1.5$ equiv), dibromide 8 (69 mg, $0.22 \mathrm{mmol}, 1$ equiv), and TBAI ( $40 \mathrm{mg}, 0.11 \mathrm{mmol}, 0.5$ equiv) in THF $(4 \mathrm{ml})$ at $0{ }^{\circ} \mathrm{C}$. The reaction was then vigorously stirred for 18 hours then diluted with $\mathrm{H}_{2} \mathrm{O}$ $(10 \mathrm{ml})$ and extracted with DCM $(3 \times 20 \mathrm{ml})$. Combined organic extracts were dried over $\mathrm{Na}_{2} \mathrm{SO}_{4}$, filtered, and concentrated to afford a yellow solid. The solid was subjected to column chromatography (10 $\mathrm{g} \mathrm{SiO}_{2}, 0-5 \%$ EtOAc in DCM, $\mathrm{R}_{f}=0.22$ in 5\% EtOAc in DCM) and afforded spirocycle 7 as a white solid $(61 \mathrm{mg}, 70 \%) .{ }^{1} \mathbf{H} \mathbf{~ N M R ~}\left(500 \mathrm{MHz}, \mathrm{CDCl}_{3}\right) \delta \mathrm{H} 6.48(1 \mathrm{H}$, s), $5.58(1 \mathrm{H}, J=9.6 \mathrm{~Hz}), 4.60(2 \mathrm{H}, \mathrm{t}, J=8.7 \mathrm{~Hz}), 4.39(1 \mathrm{H}, \mathrm{q}, J=4.4 \mathrm{~Hz}), 4.24(1 \mathrm{H}, \mathrm{d}, J=17.4$ $\mathrm{Hz}), 3.96(2 \mathrm{H}, \mathrm{d}, J=4.6 \mathrm{~Hz}), 3.75(1 \mathrm{H}, \mathrm{d}, J=16.0 \mathrm{~Hz}), 3.74(1 \mathrm{H}, \mathrm{d}, J=17.4 \mathrm{~Hz}), 3.68(1 \mathrm{H}, \mathrm{m})$, $5.57(1 \mathrm{H}, \mathrm{d}, J=16.0 \mathrm{~Hz}), 3.32(1 \mathrm{H}, \mathrm{dq}, J=15.3,2.8 \mathrm{~Hz}), 3.06(2 \mathrm{H}, \mathrm{t}, J=8.7 \mathrm{~Hz}), 2.57(1 \mathrm{H}, \mathrm{m})$, $2.23-2.31(2 \mathrm{H}, \mathrm{m}), 2.19(3 \mathrm{H}, \mathrm{s}), 0.82(3 \mathrm{H}, \mathrm{d}, J=7.0 \mathrm{~Hz}), 0.75(3 \mathrm{H}, \mathrm{d}, J=6.9 \mathrm{~Hz}) ;{ }^{13} \mathbf{C} \mathbf{~ N M R}$ $\left(126 \mathrm{MHz}, \mathrm{CDCl}_{3}\right) \delta \mathrm{C} 163.0,155.2,137.8,133.7,125.1,118.0,116.0,87.7,77.4,71.6,64.5$, 63.4, 48.1, 40.1, 33.0, 31.8, 28.6, 27.6, 19.1, 18.9, 16.0; HRMS (ESI) m/z: $[\mathrm{M}+\mathrm{Na}]^{+}$calculated for $\left[\mathrm{C}_{21} \mathrm{H}_{27} \mathrm{NO}_{5} \mathrm{SNa}\right]^{+} 428.1508$, found 428.1483; IR (neat) $\tilde{v}=2961,2930,2873,1732,1623$, $1600,1483,1457,1445,1406,1389,1372,1312,1292,1264,1227,1202,1185,1167,1129$, 1096, 1085, 1050, 1030, 1000, 969, 952, 910, 899, 888, 878, 840, 811, 797, 756, 732, $702 \mathrm{~cm}^{-1}$; $[\boldsymbol{\alpha}]_{\mathbf{D}}^{22}-212.1\left(c 1.0, \mathrm{CHCl}_{3}\right) ; \mathbf{M p} 229-231^{\circ} \mathrm{C}$.

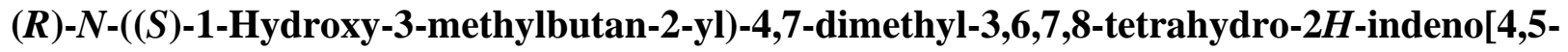
b]furan-7-carboxamide (22):
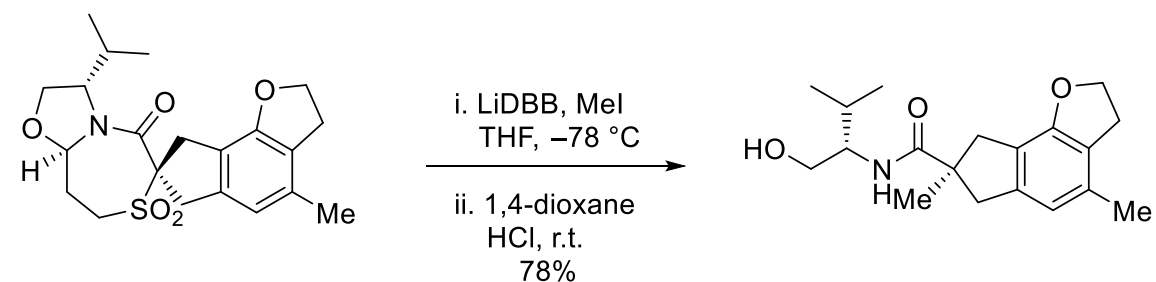

$\operatorname{LiDBB}(0.4 \mathrm{M}, 2.1$ equiv, $2.6 \mathrm{ml})$ drop-wise to a solution of spirocycle 7 (190 $\mathrm{mg}, 0.47 \mathrm{mmol}, 1$ equiv), that had been azeotropically dried with PhMe $(2 \times 15 \mathrm{ml})$, in dry and degassed THF (12 $\mathrm{ml}$ ) at $-78{ }^{\circ} \mathrm{C}$. Following the addition, the solution left to stir at $-78{ }^{\circ} \mathrm{C}$ for $20 \mathrm{~min}$. Iodomethane (117 $\mu \mathrm{l}, 1.87 \mathrm{mmol}, 4$ equiv), which had been passed through a column of basic $\mathrm{Al}_{2} \mathrm{O}_{3}$, was then added drop-wise via glass syringe and the reaction allowed to stir at $-78{ }^{\circ} \mathrm{C}$ for 6 hours. The reaction was warmed to r.t. and all volatiles removed under reduced pressure. The resulting residue was dissolved in 1,4-dioxane $(10 \mathrm{ml})$ and $1 \mathrm{M} \mathrm{HCl}_{(\mathrm{aq})}(5 \mathrm{ml})$ added. After stirring at r.t. for 12 hours the solution was adjusted to $\mathrm{pH} 7$ with $\mathrm{NaOH}_{(\mathrm{aq})}(15 \%$ w.t.) and allowed to stir at r.t for 1 hour before being extracted with EtOAc $(3 \times 15 \mathrm{ml})$. Combined organic extracts were dried over $\mathrm{Na}_{2} \mathrm{SO}_{4}$, filtered, and concentrated to afford a yellow solid which was purified by column chromatography (10 $\mathrm{g} \mathrm{SiO}_{2}, 40-50 \%$ EtOAc in hexanes, $R_{f}=0.20$ in $50 \%$ EtOAc in hexanes). 
Amide 22 was isolated as a white solid (116 mg, 78\%). ${ }^{\mathbf{1}} \mathbf{H} \mathbf{~ N M R}\left(500 \mathrm{MHz}, \mathrm{CDCl}_{3}\right) \delta \mathrm{H} 6.55$ $(1 \mathrm{H}, \mathrm{s}), 5.75\left(1 \mathrm{H}, \mathrm{d}, J=7.5 \mathrm{~Hz}, \mathrm{D}_{2} \mathrm{O}\right.$ exch. $), 4.58(2 \mathrm{H}, \mathrm{dd}, J=9.8,1.2 \mathrm{~Hz}), 3.61-3.75(3 \mathrm{H}, \mathrm{m})$, $3.33(1 \mathrm{H}, \mathrm{d}, J=15.7 \mathrm{~Hz}), 3.23(1 \mathrm{H}, \mathrm{d}, J=15.6 \mathrm{~Hz}), 3.09(2 \mathrm{H}, \mathrm{t}, J=8.7 \mathrm{~Hz}), 2.78(1 \mathrm{H}, \mathrm{d}, J=$ $15.7 \mathrm{~Hz}), 2.78(1 \mathrm{H}, \mathrm{d}, J=15.6 \mathrm{~Hz}), 2.75\left(1 \mathrm{H}, \mathrm{d}, J=5.2 \mathrm{~Hz}, \mathrm{D}_{2} \mathrm{O}\right.$ exch.), $2.14(3 \mathrm{H}, \mathrm{s}), 1.89(1 \mathrm{H}$, $\mathrm{m}), 1.38(3 \mathrm{H}, \mathrm{s}), 0.91(3 \mathrm{H}, \mathrm{d}, J=6.8 \mathrm{~Hz}), 0.86(3 \mathrm{H}, \mathrm{d}, J=6.8 \mathrm{~Hz}) ;{ }^{13} \mathbf{C ~ N M R}(126 \mathrm{MHz}$, $\left.\mathrm{CDCl}_{3}\right) \delta \mathrm{C} 178.9,155.7,142.8,133.4,124.1,119.0,117.5,71.5,64.6,57.3,50.7,44.4,40.3$, 29.0, 28.7, 25.7, 19.6, 19.0, 18.5; HRMS (ESI) $\mathbf{~ m / z : ~}[\mathrm{M}+\mathrm{Na}]^{+}$calculated for $\left[\mathrm{C}_{19} \mathrm{H}_{27} \mathrm{NO}_{3} \mathrm{Na}^{+}\right.$ 340.1889, found 340.1873; IR (neat) $\tilde{v}=3340,3001,2960,2926,2869,2853,1637,1596,1524$, 1481, 1458, 1417, 1386, 1369, 1320, 1292, 1256, 1188, 1140, 1126, 1075, 1034, 1005, 976, 961, 933, 895, 841, $731 \mathrm{~cm}^{-1} ;[\boldsymbol{\alpha}]_{\mathbf{D}}^{\mathbf{2 2}}+54.8\left(c\right.$ 1.0, $\left.\mathrm{CHCl}_{3}\right) ; \mathbf{M p} 1149-152{ }^{\circ} \mathrm{C}$.

\section{(R)-4,7-Dimethyl-3,6,7,8-tetrahydro-2H-indeno[4,5-b]furan-7-carboxylic acid (23):}

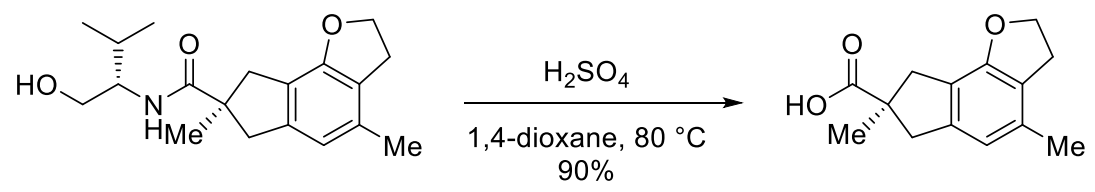

$4 \mathrm{M} \mathrm{H}_{2} \mathrm{SO}_{4(\mathrm{aq})}(1 \mathrm{ml})$ was added drop-wise to a solution of amide $22(27 \mathrm{mg}, 0.085 \mathrm{mmol})$ in 1,4dioxane $(2 \mathrm{ml})$. The solution stirred at $80{ }^{\circ} \mathrm{C}$ for 8 hours. The reaction was cooled to r.t., diluted with $\mathrm{H}_{2} \mathrm{O}(5 \mathrm{ml})$, and extracted with $\mathrm{Et}_{2} \mathrm{O}(3 \times 15 \mathrm{ml})$. Combined organic extracts were dried over $\mathrm{Na}_{2} \mathrm{SO}_{4}$, filtered, and concentrated to afford a brown solid which was purified by column chromatography (5 $\mathrm{g} \mathrm{SiO}_{2}, 3 \%$ EtOAc, $1 \% \mathrm{AcOH}$ in DCM, $R_{f}=0.20$ in $1 \% \mathrm{AcOH}$ in DCM). Carboxylic acid 23 was isolated as a white solid (26.4 mg, 90\%). ${ }^{1} \mathbf{H}$ NMR (500 MHz, $\left.\mathrm{CDCl}_{3}\right) \delta \mathrm{H} 11.57\left(1 \mathrm{H}\right.$, br. s, $\mathrm{D}_{2} \mathrm{O}$ exch. $), 6.55(1 \mathrm{H}, \mathrm{s}), 4.59(2 \mathrm{H}, \mathrm{t}, J=8.6 \mathrm{~Hz}), 3.44(1 \mathrm{H}, \mathrm{d}, J=$ $15.9 \mathrm{~Hz}), 3.38(1 \mathrm{H}, \mathrm{d}, J=15.8 \mathrm{~Hz}), 3.09(2 \mathrm{H}, \mathrm{t}, J=8.6 \mathrm{~Hz}), 2.77(1 \mathrm{H}, \mathrm{d}, J=15.9 \mathrm{~Hz}), 2.77(1 \mathrm{H}$, $\mathrm{d}, J=15.8 \mathrm{~Hz}), 2.22(3 \mathrm{H}, \mathrm{s}), 1.40(3 \mathrm{H}, \mathrm{s}) ;{ }^{13} \mathbf{C} \mathbf{~ N M R}\left(126 \mathrm{MHz}, \mathrm{CDCl}_{3}\right) \delta \mathrm{C} 184.1,155.7,142.5$, 133.2, 124.0, 119.0, 117.3, 71.5, 49.9, 43.8, 39.8, 28.7, 25.0, 19.0; HRMS m/z: [M-H] ${ }^{-}$ calculated for $\left[\mathrm{C}_{14} \mathrm{H}_{15} \mathrm{O}_{3}\right]^{-}$231.1027, found 231.1017; IR (neat) $\tilde{v}=3036,2970,2915,2855$, 2695, 2675, 2590, 2524, 1734, 1694, 1636, 1590, 1536, 1480, 1457, 1432, 1414, 1383, 1368, 1354, 1307, 1295, 1254, 1231, 1178, 1140, 1116, 1090, 1071, 1029, 1003, 977, 965, 938, 895, $868,845,795,769,739,706 \mathrm{~cm}^{-1}$.

\section{(R)-Puraquinonic acid (1):}
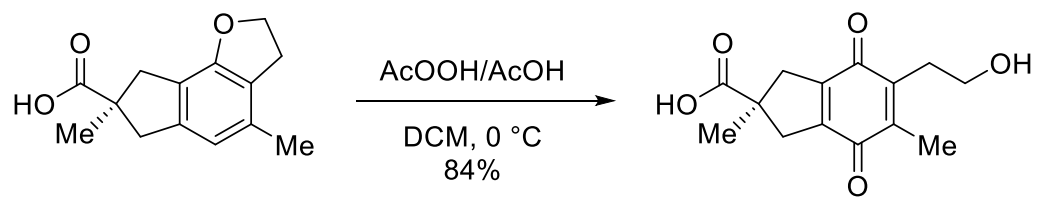

Peracetic acid (39 wt. \% in acetic acid, $500 \mu \mathrm{l}$ ) was added drop-wise to a solution of carboxylic acid $23(5.0 \mathrm{mg}, 0.022 \mathrm{mmol})$ in DCM $(1.0 \mathrm{ml})$ at $0{ }^{\circ} \mathrm{C}$. The reaction was stirred at $0{ }^{\circ} \mathrm{C}$ for 2 hours then diluted with $\mathrm{H}_{2} \mathrm{O}(5 \mathrm{ml})$ and extracted with $\mathrm{Et}_{2} \mathrm{O}(2 \times 5 \mathrm{ml})$. Combined organic extracts were washed with an additional portion of $\mathrm{H}_{2} \mathrm{O}(5 \mathrm{ml})$. The phases were separated, and the aqueous phase extracted with $\mathrm{Et}_{2} \mathrm{O}(5 \mathrm{ml})$. All organic extracts were dried over $\mathrm{Na}_{2} \mathrm{SO}_{4}$, filtered, and concentrated to afford a yellowish residue. The residue was purified by column chromatography ( $2 \mathrm{~g} \mathrm{SiO}_{2}, 0$ to $5 \% \mathrm{MeOH}$ in $\mathrm{DCM}$ ) to provide (R)-puraquinonic acid as a yellow film (4.9 mg, 84\%). Characterisation was consistant with previous reports of $(R)$ Puraquinonic acid. ${ }^{[20]}{ }^{1} \mathbf{H}$ NMR $\left(500 \mathrm{MHz} \mathrm{CDCl}_{3}\right) \delta \mathrm{H} 3.77(2 \mathrm{H}, \mathrm{t}, J=6.4 \mathrm{~Hz}), 3.39$ (2H, m), 
$2.80(2 \mathrm{H}, \mathrm{t}, J=6.4 \mathrm{~Hz}), 2.76(2 \mathrm{H}, \mathrm{m}), 2.08(3 \mathrm{H}, \mathrm{s}), 1.43(3 \mathrm{H}, \mathrm{s}) ;{ }^{13} \mathrm{C}$ NMR $(101 \mathrm{MHz}$, $\left.\mathrm{CDCl}_{3}\right) \delta \mathrm{C} 186.2,185.7 .180 .5,145.7,145.3,142.8,141.4,61.5,46.8,42.3,42.3,29.9,25.7$, 12.2; HRMS (ESI) $\mathbf{m} / \mathbf{z}:[\mathrm{M}+\mathrm{Na}]^{+}$calculated for $\left[\mathrm{C}_{14} \mathrm{H}_{16} \mathrm{O}_{5} \mathrm{Na}\right]^{+} 287.0890$, found 287.0899; IR (neat) $\tilde{v}=3440,2925,1707,1647,1607,1431,1376,1334,1265,1209,1110,1037,1021,908$, $801,733,702 \mathrm{~cm}^{-1} ;[\boldsymbol{\alpha}]_{\mathbf{D}}^{22}+3.5\left(c 0.5, \mathrm{CHCl}_{3}\right)$.

\section{Benzyl (R)-(1-(methoxymethoxy)-3-methylbutan-2-yl)carbamate (S13):}

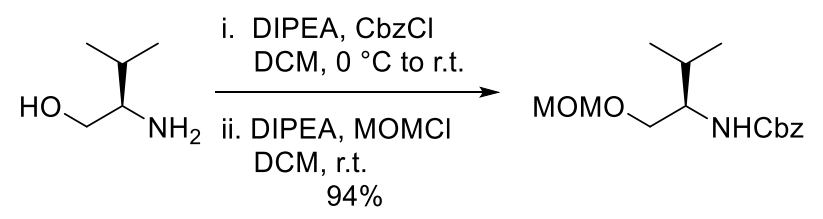

DIPEA (870 $\mu \mathrm{l}, 5.0 \mathrm{mmol}, 1$ equiv) and benzyl chloroformate ( $896 \mu \mathrm{l}, 5.25 \mathrm{mmol}, 1.05$ equiv) were added to a solution of $(R)$-valinol $\left(515 \mathrm{mg}, 5.00 \mathrm{mmol}, 1\right.$ equiv) in DCM $(25 \mathrm{ml})$ at $0{ }^{\circ} \mathrm{C}$. The reaction was then warmed to r.t. and left to stir overnight. At this time TLC inspection showed no $(R)$-valinol. A second portion of DIPEA $(1.74 \mathrm{ml}, 10.0 \mathrm{mmol}, 2$ equiv) was added followed by chloromethyl methyl ether $(570 \mu \mathrm{l}, 7.50 \mathrm{mmol}, 1.5$ equiv). The reaction was then left to stir at r.t. for 24 hours before being diluted with sat. $\mathrm{NH}_{4} \mathrm{Cl}_{(\mathrm{aq})}(30 \mathrm{ml})$ and extracted with DCM $(2 \times 50 \mathrm{ml})$. Combined organic extracts were dried over $\mathrm{MgSO}_{4}$, filtered, and concentrated to afford a yellow-orange liquid. The liquid was purified by column chromatography $\left(24 \mathrm{~g} \mathrm{SiO}_{2}\right.$, $0-60 \%$ EtOAc in hexanes, $30 \mathrm{ml} / \mathrm{min}, 15 \mathrm{~min}$ ) to afford carbamate $\mathbf{S 1 3}$ as a clear colourless viscous liquid (1.32 g, 94\%). ${ }^{\mathbf{1}} \mathbf{H}$ NMR $\left(500 \mathrm{MHz}, \mathrm{CDCl}_{3}\right) \delta \mathrm{H} 7.31-7.39(5 \mathrm{H}, \mathrm{m}), 5.13(2 \mathrm{H}, \mathrm{s})$, $4.97\left(1 \mathrm{H}, \mathrm{d}, J=8.2 \mathrm{~Hz}, \mathrm{D}_{2} \mathrm{O}\right.$ exch. $), 4.62(2 \mathrm{H}, \mathrm{s}), 3.64(1 \mathrm{H}, \mathrm{m}), 3.54(1 \mathrm{H}, \mathrm{dd}, J=9.8,3.7 \mathrm{~Hz})$, $3.36(3 \mathrm{H}, \mathrm{s}) 1.92(1 \mathrm{H}, \mathrm{m}), 0.99(3 \mathrm{H}, \mathrm{d}, J=6.8 \mathrm{~Hz}), 0.96(3 \mathrm{H}, \mathrm{d}, J=6.8 \mathrm{~Hz}) ;{ }^{1} \mathbf{H} \mathbf{~ N M R}(500$ MHz, DMSO-d $)_{6} \delta \mathrm{H} 7.35(4 \mathrm{H}, \mathrm{m}), 7.30(1 \mathrm{H}, \mathrm{m}), 7.13\left(1 \mathrm{H}, \mathrm{d}, J=8.6 \mathrm{~Hz}, \mathrm{D}_{2} \mathrm{O}\right.$ exch.), $5.02(2 \mathrm{H}$, $\mathrm{s}), 4.54(2 \mathrm{H}, \mathrm{m}), 3.47(2 \mathrm{H}, \mathrm{m}), 3.40(1 \mathrm{H}, \mathrm{m}), 3.23(3 \mathrm{H}, \mathrm{s}), 1.78(1 \mathrm{H}, \mathrm{dqq}, J=6.8,6.8,6.7 \mathrm{~Hz})$, $0.86(3 \mathrm{H}, \mathrm{d}, J=6.8 \mathrm{~Hz}), 0.84(3 \mathrm{H}, \mathrm{d}, J=6.8 \mathrm{~Hz}) ;{ }^{13} \mathbf{C} \mathbf{N M R}\left(126 \mathrm{MHz}, \mathrm{CDCl}_{3}\right) \delta \mathrm{C} 156.14$, 136.7, $128.5,128.1,96.7,68.1,66.7,56.2,55.4,29.6,19.5,18.7 ;{ }^{13}$ C NMR $(126 \mathrm{MHz}$, DMSO$d_{6)} \delta \mathrm{C} 156.2,137.4,128.3,127.7,127.6,95.7,67.5,65.0,55.8,54.6,29.0,19.3,18.0$; HRMS (ESI) $\mathbf{m} / \mathbf{z}:[\mathrm{M}+\mathrm{Na}]^{+}$calculated for $\left[\mathrm{C}_{15} \mathrm{H}_{23} \mathrm{NO}_{4} \mathrm{Na}\right]^{+} 304.1519$, found 304.1516 ; IR (neat) $\tilde{v}=$ 3335, 3067, 3033, 2959, 2933, 2882, 2824, 2770, 1698, 1587, 1529, 1466, 1455, 1403, 1389, $1370,1334,1310,1280,1230,1152,1109,1026,956,918,846,824,775,738,697 \mathrm{~cm}^{-1}$.

\section{(R)-1-(Methoxymethoxy)-3-methylbutan-2-amine (S14):}

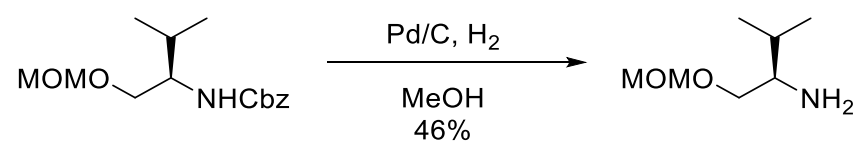

$\mathrm{Pd} / \mathrm{C}$ (5 wt $\%, 10 \mathrm{mg}, 4.7 \mathrm{nmol}, 5 \mathrm{~mol} \%$ ) was added to a solution of carbamate $\mathbf{S 1 3}$ (200 mg, 0.71 mmol, 1 equiv) in $\mathrm{MeOH}(1 \mathrm{ml})$ under an argon atmosphere at r.t. The flask was then equipped with a balloon of $\mathrm{H}_{2}$ with the $\mathrm{H}_{2}$ allowed to bubble through the solution for 5 min to remove argon. The reaction was then allowed to stir at r.t. under a $\mathrm{H}_{2}$ atmosphere for $40 \mathrm{~min}$ at which point TLC indicated the reaction was complete. The solution was filtered through a small pad of celite and rinsed with $\mathrm{Et}_{2} \mathrm{O}$. The filtrate was diluted with sat. $\mathrm{NaHCO}_{3}(10 \mathrm{ml})$ then extracted with $\mathrm{Et}_{2} \mathrm{O}(3 \times 20 \mathrm{ml})$. Combined organic extracts were dried over $\mathrm{Na}_{2} \mathrm{SO}_{4}$, filtered, and concentrated to afford amine $\mathbf{S 1 4}$ as a slightly yellow liquid (48 $\mathrm{mg}, 46 \%$ ) which was used without further purification. ${ }^{\mathbf{1}} \mathbf{H} \mathbf{N M R}\left(500 \mathrm{MHz}^{\mathrm{CDCl}} \mathrm{CDC}_{3} \delta \mathrm{H} 4.58(2 \mathrm{H}, \mathrm{m}), 3.53(1 \mathrm{H}, \mathrm{dd},, J=\right.$ 
9.3, $3.5 \mathrm{~Hz}), 3.31(3 \mathrm{H}, \mathrm{s}), 3.28(1 \mathrm{H}, \mathrm{dd},, J=9.5,8.2 \mathrm{~Hz}), 2.68(1 \mathrm{H}, \mathrm{ddd}, J=8.2,5.9,3.7 \mathrm{~Hz})$, $1.59(1 \mathrm{H}$, octet, $J=6.8 \mathrm{~Hz}) 1.58\left(2 \mathrm{H}\right.$, br. s, $\mathrm{D}_{2} \mathrm{O}$ exch.); ${ }^{13} \mathbf{C} \mathbf{~ N M R}\left(126 \mathrm{MHz}, \mathrm{CDCl}_{3}\right) \delta \mathrm{C} 96.6$, 71.3 56.2, 30.8, 19.2, 18.0; HRMS (APCI) m/z: $[\mathrm{M}+\mathrm{H}]^{+}$calculated for $\left[\mathrm{C}_{7} \mathrm{H}_{18} \mathrm{NO}_{2}\right]^{+} 148.1332$, found 148.1326; IR (neat) $\tilde{v}=3381,3302,2955,2929,2877,2825,2774,1728,1611,1592$, 1566, 1466, 1437, 1388, 1368, 1297, 1268, 1218, 1193, 1143, 1108, 1041, 999, 917, 858, 840, $793,770,735,699 \mathrm{~cm}^{-1}$.

$(R)-N-((R)-1-(M e t h o x y m e t h o x y)-3-m e t h y l b u t a n-2-y l)-4,7-d i m e t h y l-3,6,7,8-t e t r a h y d r o-2 H-$ indeno[4,5-b]furan-7-carboxamide (S15):

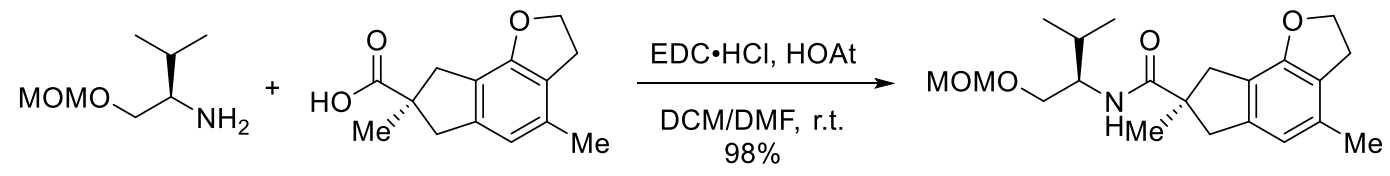

$\mathrm{EDC} \cdot \mathrm{HCl}$ (19 mg, $0.097 \mathrm{mmol}, 1.5$ equiv), and HOAt (13 mg, $0.097 \mathrm{mmol}, 1.5$ equiv) were added to a solution of carboxylic acid 23 (15 mg, $0.065 \mathrm{mmol}, 1$ equiv) in 6:1 DCM/DMF (1.75 $\mathrm{ml})$ at $0{ }^{\circ} \mathrm{C}$. The solution was stirred at $0{ }^{\circ} \mathrm{C}$ for 15 minutes before amine $\mathbf{S 1 4}(29 \mathrm{mg}, 0.20$ mmol, 3 equiv) was added as a solution in DCM $(1 \mathrm{ml})$ via syringe. The reaction was then warmed to r.t. and left to stir overnight. The reaction was diluted with $\mathrm{H}_{2} \mathrm{O}(8 \mathrm{ml})$ and then extracted with $\mathrm{Et}_{2} \mathrm{O}(3 \times 20 \mathrm{ml})$. Combined organic extracts were dried over $\mathrm{Na}_{2} \mathrm{SO}_{4}$, filtered, and concentrated to afford a yellowish residue. The residue was purified by column chromatography (8 $\mathrm{g} \mathrm{SiO}_{2}, 40 \%$ EtOAc in hexanes) to afford amide $\mathbf{S 1 5}$ as a colourless liquid (25 mg, 98\%). ${ }^{1} \mathbf{H}$ NMR $\left(500 \mathrm{MHz}, \mathrm{CDCl}_{3}\right) \delta \mathrm{H} 6.57(1 \mathrm{H}, \mathrm{s}), 5.88\left(1 \mathrm{H}, \mathrm{d}, J=9.0 \mathrm{~Hz}, \mathrm{D}_{2} \mathrm{O}\right.$ exch.), $4.60(2 \mathrm{H}, \mathrm{t}, J=8.5 \mathrm{~Hz}), 4.60(2 \mathrm{H}, \mathrm{s}), 3.90(1 \mathrm{H}, \mathrm{m}), 3.73(1 \mathrm{H}, \mathrm{dd}, J=10.2,3.7 \mathrm{~Hz}), 3.47$ $(1 \mathrm{H}, \mathrm{dd}, J=10.2,3.9 \mathrm{~Hz}), 3.37(1)(1 \mathrm{H}, \mathrm{d}, J=15.7 \mathrm{~Hz}), 3.37(0)(3 \mathrm{H}, \mathrm{s}), 3.25(1 \mathrm{H}, \mathrm{d}, J=15.7$ $\mathrm{Hz}), 3.11(2 \mathrm{H}, \mathrm{t}, J=8.7 \mathrm{~Hz}), 2.79(1 \mathrm{H}, \mathrm{d}, J=15.6 \mathrm{~Hz}), 2.78(1 \mathrm{H}, \mathrm{d}, J=15.8 \mathrm{~Hz}), 2.24(3 \mathrm{H}, \mathrm{s})$, $1.91(1 \mathrm{H}, \mathrm{qqd}, J=7.5,7.5,7.5 \mathrm{~Hz}), 1.38(3 \mathrm{H}, \mathrm{s}), 0.97(3 \mathrm{H}, \mathrm{d}, J=6.8 \mathrm{~Hz}), 0.91(3 \mathrm{H}, \mathrm{d}, J=6.9$ $\mathrm{Hz}) ;{ }^{13} \mathrm{C}$ NMR $\left(126 \mathrm{MHz}, \mathrm{CDCl}_{3}\right) \delta \mathrm{C} 177.1,155.8,143.0,133.2,124.0,119.1,117.4,96.9$, 71.5, 68.4, 55.4, 53.9, 50.7, 44.1, 40.2, 29.5, 28.8, 25.8, 19.6, 19.0, 18.8; HRMS (ESI) m/z: $[\mathrm{M}+\mathrm{Na}]^{+}$calculated for $\left[\mathrm{C}_{21} \mathrm{H}_{31} \mathrm{O}_{4} \mathrm{NNa}\right]^{+} 384.2145$, found 384.2148; IR (neat) $\tilde{v}=3448,3346$, 2958, 2927, 2821, 1728, 1641, 1595, 1522, 1479, 1459, 1417, 1386, 1370, 1318, 1290, 1258, 1214, 1187, 1141, 111, 1075, 1035, 1005, 976, 963, 920, 895, 840, 776, 733, $702 \mathrm{~cm}^{-1}$.

(R)-5-(2-Hydroxyethyl)-N-((R)-1-(methoxymethoxy)-3-methylbutan-2-yl)-2,6-dimethyl-4,7dioxo-2,3,4,7-tetrahydro-1H-indene-2-carboxamide (S16):

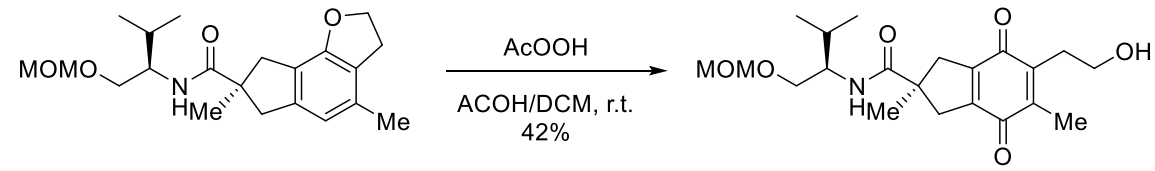

Peracetic acid (39\% in AcOH, $500 \mu \mathrm{l})$ was added to a solution of amide $\mathbf{S 1 3}(5.0 \mathrm{mg}, 0.014$ $\mathrm{mmol})$ in DCM $(1 \mathrm{ml})$. The reaction stirred at r.t. for 1 hour. The reaction was then diluted with $\mathrm{H}_{2} \mathrm{O}(5 \mathrm{ml})$ and extracted with DCM $(2 \times 10 \mathrm{ml})$. Combined organic extracts were dried over $\mathrm{Na}_{2} \mathrm{SO}_{4}$, filtered, and concentrated to afford a yellow residue. The residue was purified by preparative TLC (230-400 mesh silica, 2\% MeOH in DCM) to afford the desired quinone $\mathbf{S 1 6}$ as a yellow film (2.1 mg, 42\%). ${ }^{1} \mathbf{H}$ NMR $\left(400 \mathrm{MHz} \mathrm{CDCl}_{3}\right) \delta \mathrm{H} 5.95\left(1 \mathrm{H}, \mathrm{d}, J=9.2 \mathrm{~Hz}, \mathrm{D}_{2} \mathrm{O}\right.$ exch.), $4.61(2 \mathrm{H}, \mathrm{m}), 3.86(1 \mathrm{H}, \mathrm{m}), 3.76(2 \mathrm{H}, \mathrm{m}), 3.65(1 \mathrm{H}, \mathrm{m}), 3.48(1 \mathrm{H}, \mathrm{m}), 3.37(3 \mathrm{H}, \mathrm{s}), 3.36$ $(1 \mathrm{H}, \mathrm{m}), 3.33(1 \mathrm{H}, \mathrm{m}), 2.79(2 \mathrm{H}, \mathrm{t}, J=6.6 \mathrm{~Hz}) 2.73(1 \mathrm{H}, \mathrm{m}), 2.69(1 \mathrm{H}, \mathrm{m}), 2.08(3 \mathrm{H}, \mathrm{s}), 1.91$ 
$(1 \mathrm{H}, \mathrm{m}), 1.61\left(1 \mathrm{H}, \mathrm{t}, J=5.3 \mathrm{~Hz}, \mathrm{D}_{2} \mathrm{O}\right.$ exch. $), 1.38(3 \mathrm{H}, \mathrm{s}), 0.97(3 \mathrm{H}, \mathrm{d}, J=6.7 \mathrm{~Hz}), 0.93(3 \mathrm{H}, \mathrm{d}$, $J=6.8 \mathrm{~Hz}) ;{ }^{13} \mathrm{C}$ NMR $\left(126 \mathrm{MHz}, \mathrm{CDCl}_{3}\right) \delta \mathrm{C} 186.4,185.9,175.7,145.9,145.6,142.8,141.4$, 97.0, 68.6, 61.5, 55.5, 54.3, 47.8, 42.8, 42.6, 29.9, 29.6, 26.6, 19.6, 19.2, 12.2; HRMS (ESI) $\mathbf{m} / \mathbf{z}:[\mathrm{M}+\mathrm{Na}]^{+}$calculated for $\left[\mathrm{C}_{21} \mathrm{H}_{31} \mathrm{O}_{6} \mathrm{NNa}\right]^{+} 416.2044$, found 416.2052; IR (neat) $\tilde{v}=3352$, 2959, 2926, 2874, 2855, 1725, 1639, 1530, 1462, 1377, 1267, 1215, 1148, 1110, 1035, 955, 920, $735,702,603,541 \mathrm{~cm}^{-1}$.

\section{(R)- $\mathrm{N}$-((S)-1-(Methoxymethoxy)-3-methylbutan-2-yl)-4,7-dimethyl-3,6,7,8-tetrahydro-2H- indeno[4,5-b]furan-7-carboxamide (S17):}

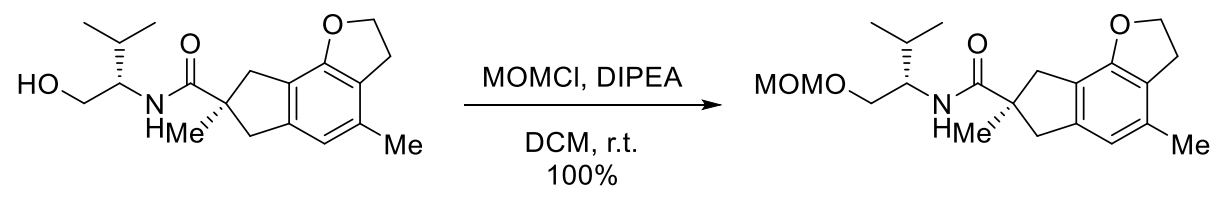

DIPEA (54 $\mu \mathrm{l}, 0.32 \mathrm{mmol}, 10$ equiv) followed by $\mathrm{MOMCl}(20 \mu \mathrm{l}, 0.15 \mathrm{mmol}, 8$ equiv) were added to a solution of amide 22 (10 $\mathrm{mg}, 0.032 \mathrm{mmol}, 1$ equiv) in DCM (3 ml) at r.t. and left to stir at overnight. The reaction was quenched with sat. $\mathrm{NH}_{4} \mathrm{Cl}(5 \mathrm{ml})$ and the resulting solution extracted with DCM $(3 \times 10 \mathrm{ml})$. Combined organic extracts were dried over $\mathrm{Na}_{2} \mathrm{SO}_{4}$, filtered, and concentrated to afford a yellow residue which was purified by column chromatography (3 $\mathrm{g}$ $\mathrm{SiO}_{2}, 40 \%$ EtOAc in hexanes) affording amide $\mathbf{S 1 7}$ as a white film (11 mg, 97\%). ${ }^{\mathbf{1}} \mathbf{H}$ NMR (500 $\left.\mathrm{MHz} \mathrm{CDCl}_{3}\right) \delta \mathrm{H} 6.55(1 \mathrm{H}, \mathrm{s}), 5.85\left(1 \mathrm{H}, \mathrm{d}, J=9.1 \mathrm{~Hz}, \mathrm{D}_{2} \mathrm{O}\right.$ exch. $), 4.58(2 \mathrm{H}, \mathrm{t}, J=8.7 \mathrm{~Hz}), 4.58$ $(\mathrm{s}, 2 \mathrm{H}), 3.88(1 \mathrm{H}, \mathrm{m}), 3.70(1 \mathrm{H}, \mathrm{dd}, J=3.8,10.2 \mathrm{~Hz}), 3.46(1 \mathrm{H}, \mathrm{dd}, J=3.8,10.2 \mathrm{~Hz}), 3.35(1 \mathrm{H}$, d, $15.6 \mathrm{~Hz}), 3.35(3 \mathrm{H}, \mathrm{s}), 3.24(1 \mathrm{H}, \mathrm{d}, J=15.5 \mathrm{~Hz}), 3.09(2 \mathrm{H}, \mathrm{t}, J=8.2 \mathrm{~Hz}), 2.76(1 \mathrm{H}, \mathrm{d}, J=15.5$ $\mathrm{Hz}), 2.76(1 \mathrm{H}, \mathrm{d}, J=15.5 \mathrm{~Hz}), 2.22(3 \mathrm{H}, \mathrm{s}), 1.88(1 \mathrm{H}, \mathrm{m}), 1.36(3 \mathrm{H}, \mathrm{s}), 0.94(3 \mathrm{H}, \mathrm{d}, J=6.8 \mathrm{~Hz})$, $0.88(3 \mathrm{H}, \mathrm{d}, J=6.9 \mathrm{~Hz}) ;{ }^{13} \mathbf{C}$ NMR $\left(126 \mathrm{MHz}, \mathrm{CDCl}_{3}\right) \delta \mathrm{C} 177.1,155.7,142.9,133.2,123.9$, $119.1,117.5,96.9,71.5,68.4,55.4,53.8,50.7,44.1,40.2,29.5,28.7,25.8,19.6,19.0,18.8$; HRMS (ESI) $\mathbf{~ m / z : ~}[\mathrm{M}+\mathrm{Na}]^{+}$calculated for $\left[\mathrm{C}_{21} \mathrm{H}_{31} \mathrm{NO}_{4} \mathrm{Na}\right]^{+} 384.2145$, found 384.2133. IR (neat) $\tilde{v}=3345,2958,2967,1639,1595,1525,1460,1417,1386,1290,1256,1214,1187,1143$, $1112,1075,1036,1006,958,920,841,730,578,536,428 \mathrm{~cm}^{-1}$.

(R)-5-(2-Hydroxyethyl)- $N$-((S)-1-(methoxymethoxy)-3-methylbutan-2-yl)-2,6-dimethyl-4,7dioxo-2,3,4,7-tetrahydro-1H-indene-2-carboxamide (24):
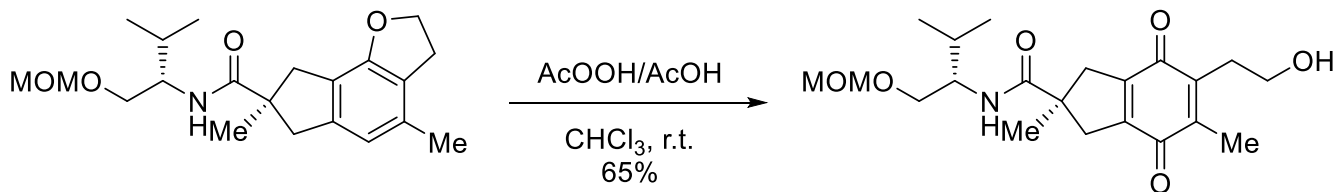

Peracetic acid (39\% in AcOH, $50 \mu \mathrm{l})$ was added to a solution of amide S15 (10 mg, $0.028 \mathrm{mmol}$ ) in $\mathrm{CHCl}_{3}(1 \mathrm{ml})$. The reaction stirred at r.t. for 10 hours. The reaction was then diluted with sat. $\mathrm{NaHCO}_{3(\mathrm{aq})}(1 \mathrm{ml})$ and extracted with $\mathrm{DCM}(3 \times 2 \mathrm{ml})$. Combined organic extracts were dried over $\mathrm{Na}_{2} \mathrm{SO}_{4}$, filtered, and concentrated to afford a yellow residue. The residue was purified by preparative TLC (230-400 mesh silica, 2\% MeOH in DCM) to afford quinone 24 as a yellow film (7.2 mg, 65\%). Spectra agreed with previous reports. ${ }^{\text {[20a] }}{ }^{1} \mathbf{H} \mathbf{~ N M R}\left(400 \mathrm{MHz}, \mathrm{CDCl}_{3}\right) \delta \mathrm{H}$ $5.96\left(1 \mathrm{H}, \mathrm{d}, J=9.1 \mathrm{~Hz}, \mathrm{D}_{2} \mathrm{O}\right.$ exch. $), 4.60(2 \mathrm{H}, \mathrm{m}), 3.85(1 \mathrm{H}, \mathrm{m}), 3.75(3 \mathrm{H}, \mathrm{m}), 3.47(1 \mathrm{H}, \mathrm{dd}, J=$ $10.3,3.5 \mathrm{~Hz}), 3.37(3 \mathrm{H}, \mathrm{s}), 3.36(1 \mathrm{H}, \mathrm{m}), 3.32(1 \mathrm{H}, \mathrm{m}), 2.79(2 \mathrm{H}, \mathrm{t}, J=6.5 \mathrm{~Hz}) 2.73(1 \mathrm{H}, \mathrm{d}, J=$ $3.3 \mathrm{~Hz}), 2.68(1 \mathrm{H}, \mathrm{d}, J=3.4 \mathrm{~Hz}), 2.07(3 \mathrm{H}, \mathrm{s}), 1.91(1 \mathrm{H}, \mathrm{m}), 1.38(3 \mathrm{H}, \mathrm{s}), 0.97(3 \mathrm{H}, \mathrm{d}, J=6.7$ $\mathrm{Hz}), 0.93(3 \mathrm{H}, \mathrm{d}, J=6.8 \mathrm{~Hz}) ;{ }^{13} \mathbf{C}$ NMR $\left(101 \mathrm{MHz}, \mathrm{CDCl}_{3}\right) \delta \mathrm{C} 186.4,185.9,175.8,145.9$, 
145.5, 142.7, 141.4, 97.0, 68.5, 61.5, 55.5, 54.3, 47.8, 42.7, 42.6, 29.9, 29.6, 26.5, 19.5, 19.1, 12.2; HRMS (ESI) $\mathbf{m} / \mathbf{z}$ : $[\mathrm{M}+\mathrm{Na}]^{+}$calculated for $\left[\mathrm{C}_{21} \mathrm{H}_{31} \mathrm{O}_{6} \mathrm{NNa}\right]^{+} 416.2044$, found 416.2049; $[\boldsymbol{\alpha}]_{\mathrm{D}}^{\mathbf{2 2}}-221.4\left(c 1.0, \mathrm{CHCl}_{3}\right)$.

\section{(R)-4-methoxy-2-methyl-2,3-dihydro-1H-indene-2-carboxylic acid (S18):}
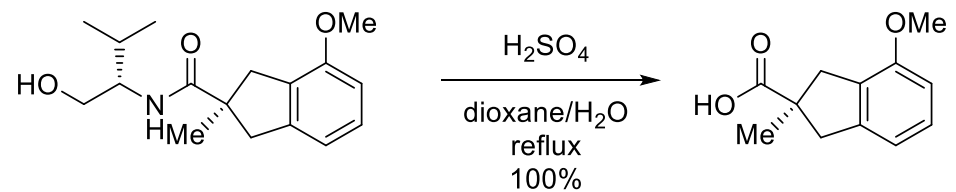

$4 \mathrm{M} \mathrm{H}_{2} \mathrm{SO}_{4(\mathrm{aq})}(6 \mathrm{ml})$ was added drop-wise to a solution of amide 17a $(118 \mathrm{mg}, 0.40 \mathrm{mmol})$ in 1,4-dioxane $(6 \mathrm{ml})$. The solution stirred at reflux for 4 hours. The reaction was cooled to r.t., diluted with $\mathrm{H}_{2} \mathrm{O}(20 \mathrm{ml})$, and extracted with $\mathrm{Et}_{2} \mathrm{O}(3 \times 25 \mathrm{ml})$. Combined organic extracts were dried over $\mathrm{MgSO}_{4}$, filtered, and concentrated to afford carboxylic acid $\mathbf{S 1 8}$ as a yellow-brown. ${ }^{1} \mathbf{H}$ NMR $\left(500 \mathrm{MHz} \mathrm{CDCl}_{3}\right) \delta \mathrm{H} 11.59$ (1H, br. s, $\mathrm{D}_{2} \mathrm{O}$ exch.), 7.15 (H, dd, J = 7.8, $7.8 \mathrm{~Hz}$ ), 6.81 $(\mathrm{H}, \mathrm{d}, J=7.8 \mathrm{~Hz}), 6.69(1 \mathrm{H}, \mathrm{d}, J=7.8 \mathrm{~Hz}), 3.82(3 \mathrm{H}, \mathrm{s}), 3.53(1 \mathrm{H}, \mathrm{d}, J=16.0 \mathrm{~Hz}), 3.42(1 \mathrm{H}, \mathrm{d}$, $J=16.4 \mathrm{~Hz}), 2.86(1 \mathrm{H}, \mathrm{d}, J=16.4 \mathrm{~Hz}), 2.84(1 \mathrm{H}, \mathrm{d}, J=16.0 \mathrm{~Hz}), 1.41(3 \mathrm{H}, \mathrm{s}) ;{ }^{13} \mathbf{C}$ NMR $(126$ $\left.\mathrm{MHz}, \mathrm{CDCl}_{3}\right) \delta \mathrm{C} 183.8,156.1,143.0,128.7,128.1,117.0,108.1,55.2,49.2,44.2,40.7,25.1$; HRMS (APCI) m/z: $[\mathrm{M}-\mathrm{H}]^{-}$calculated for $\left[\mathrm{C}_{12} \mathrm{H}_{13} \mathrm{O}_{3}\right]^{-} 205.0870$, found 205.0862; IR (neat) $\tilde{v}$ $=3080,2933,2706,2607,1699,1590,1485,1471,1439,1312,1290,1261,1231,1124,1120$, $1076,941,926,763,737 \mathrm{~cm}^{-1}$.

\section{Isopropyl ((R)-4-methoxy-2-methyl-2,3-dihydro-1H-indene-2-carbonyl)- $L$-prolinate (S19):}
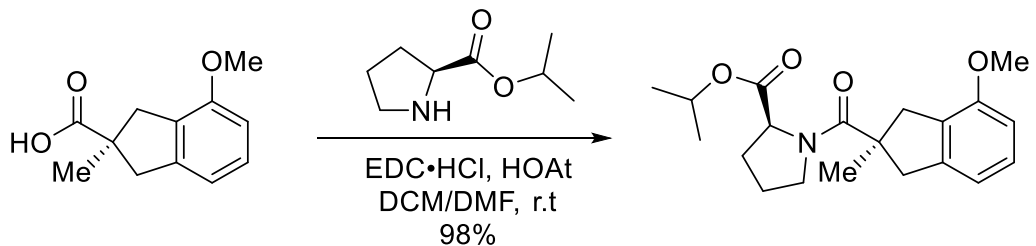

$\mathrm{EDC} \cdot \mathrm{HCl}$ (14.4 mg, $0.075 \mathrm{mmol}, 1.5$ equiv) and HOAt (10.2 mg, $0.075 \mathrm{mmol}, 1.5$ equiv) were added to a solution of carboxylic acid $\mathbf{S 1 8}(10.0 \mathrm{mg}, 0.05 \mathrm{mmol}, 1$ equiv) in a 1:1 solution of $\mathrm{DCM}$ and DMF $(0.5 \mathrm{ml})$ at $0{ }^{\circ} \mathrm{C}$. The solution was stirred at $0{ }^{\circ} \mathrm{C}$ for $15 \mathrm{~min}$ before isopropyl- $L-$ proline $(60 \mathrm{mg}, 0.38 \mathrm{mmol}, 7.6$ equiv) was added drop-wise as a solution in DCM and DMF $(1: 1,0.6 \mathrm{ml})$. After being left to stir at r.t overnight, the reaction was diluted with sat. $\mathrm{NH}_{4} \mathrm{Cl}_{(\mathrm{aq})}$ $(2.5 \mathrm{ml})$ and $\mathrm{H}_{2} \mathrm{O}(2.5 \mathrm{ml})$ with the resulting solution extracted with $\mathrm{Et}_{2} \mathrm{O}(2 \times 20 \mathrm{ml})$. Combined organic extracts were dried over $\mathrm{Na}_{2} \mathrm{SO}_{4}$, filtered, and concentrated to afford an off-white solid. The solid was purified by column chromatography (10 $\mathrm{g} \mathrm{SiO}_{2}, 40 \%$ EtOAc in hexanes) to provide amide $\mathbf{S 1 9}$ as a white solid $(17 \mathrm{mg}, 98 \%)$. Spectra are in agreement with data reported for the product. ${ }^{[21]}{ }^{1} \mathbf{H}$ NMR $\left(500 \mathrm{MHz}, \mathrm{CDCl}_{3}\right) \delta \mathrm{H} 7.15(\mathrm{H}, \mathrm{dd}, J=8.1,7.4 \mathrm{~Hz}), 6.82(1 \mathrm{H}, \mathrm{d}, J$ $=7.4 \mathrm{~Hz}), 6.68(1 \mathrm{H}, \mathrm{d}, J=8.1 \mathrm{~Hz}), 5.03(1 \mathrm{H}, \mathrm{qq}, J=6.3,6.2), 4.50(1 \mathrm{H}, \mathrm{dd}, J=8.4,4.0 \mathrm{~Hz})$, $3.82(1 \mathrm{H}, \mathrm{s}), 3.75(1 \mathrm{H}, \mathrm{m}), 3.69(1 \mathrm{H}, \mathrm{m}), 3.61(1 \mathrm{H}, \mathrm{d}, J=16.3 \mathrm{~Hz}), 3.33(1 \mathrm{H}, \mathrm{d}, J=16.1 \mathrm{~Hz})$, $2.95(1 \mathrm{H}, \mathrm{d}, J=16.1 \mathrm{~Hz}), 2.87(1 \mathrm{H}, \mathrm{d}, J=16.3 \mathrm{~Hz}), 2.15(1 \mathrm{H}, \mathrm{m}), 2.06(1 \mathrm{H}, \mathrm{m}), 1.96(1 \mathrm{H}, \mathrm{m})$, $1.90(1 \mathrm{H}, \mathrm{m}), 1.37(3 \mathrm{H}, \mathrm{s}), 1.26(3 \mathrm{H}, \mathrm{d}, J=6.3 \mathrm{~Hz}), 1.21(3 \mathrm{H}, \mathrm{d}, J=6.2 \mathrm{~Hz}) ;{ }^{13} \mathbf{C}$ NMR $(126$ $\left.\mathrm{MHz}, \mathrm{CDCl}_{3}\right) \delta \mathrm{C} 175.8,172.1,156.1,143.0,128.3,128.0,117.1,107.8,68.1,60.7,55.1,49.7$, 47.6, 44.8, 40.1, 28.1, 25.6, 25.0, 21.8, 21.7; HRMS (APCI) $\mathbf{m} / \mathbf{z}:[\mathrm{M}+\mathrm{H}]^{+}$calculated for 
$\left[\mathrm{C}_{20} \mathrm{H}_{28} \mathrm{O}_{4} \mathrm{~N}\right]^{+}$346.2013, found 346.2016; IR (neat) $\tilde{v}=2976,2937,2877,1734,1625,1592$, $1485,1401,1372,1265,1108,1076,922,767,729,707 \mathrm{~cm}^{-1}$.

Isopropyl ((R)-4-methoxy-2-methyl-2,3-dihydro-1H-indene-2-carbonyl)-D-prolinate (S20):
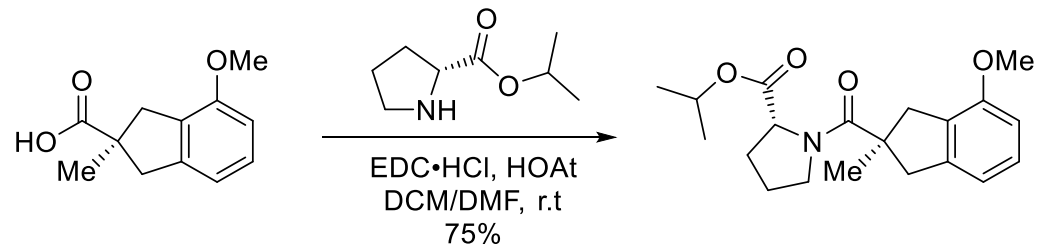

$\mathrm{EDC} \cdot \mathrm{HCl}(24 \mathrm{mg}, 0.12 \mathrm{mmol}, 1.5$ equiv) and $\mathrm{HOAt}(17 \mathrm{mg}, 0.12 \mathrm{mmol}, 1.5$ equiv) were added to a solution of carboxylic acid $\mathbf{S 1 8}(17 \mathrm{mg}, 0.082 \mathrm{mmol}, 1$ equiv) in a 1:1 solution of DCM and $\operatorname{DMF}(0.5 \mathrm{ml})$ at $0{ }^{\circ} \mathrm{C}$. The solution was stirred at $0{ }^{\circ} \mathrm{C}$ for $15 \mathrm{~min}$ before isopropyl- $D$-proline $(52$ $\mathrm{mg}, 0.33 \mathrm{mmol}, 4.0$ equiv) was added drop-wise as a solution in DCM and DMF (1:1, $0.6 \mathrm{ml})$. After being left to stir at r.t for $12 \mathrm{~h}$, the reaction was diluted with sat. $\mathrm{NH}_{4} \mathrm{Cl}_{(\mathrm{aq})}(2.5 \mathrm{ml})$ and $\mathrm{H}_{2} \mathrm{O}(2.5 \mathrm{ml})$ with the resulting solution extracted with $\mathrm{Et}_{2} \mathrm{O}(2 \times 20 \mathrm{ml})$. Combined organic extracts were dried over $\mathrm{Na}_{2} \mathrm{SO}_{4}$, filtered, and concentrated to afford an off-white solid. The solid was purified by column chromatography $\left(10 \mathrm{~g} \mathrm{SiO}_{2}, 10\right.$ to $30 \%$ EtOAc in hexanes) to provide amide S20 as a colourless film $(15 \mathrm{mg}, 75 \%)$. Spectra are in agreement with data reported for the product. ${ }^{[21]}{ }^{1} \mathbf{H} \mathbf{N M R}\left(500 \mathrm{MHz}, \mathrm{CDCl}_{3}\right) \delta \mathrm{H} 7.15(\mathrm{H}, \mathrm{dd}, J=8.1,7.5 \mathrm{~Hz}), 6.82$ $(1 \mathrm{H}, \mathrm{d}, J=7.5 \mathrm{~Hz}), 6.68(1 \mathrm{H}, \mathrm{d}, J=8.1 \mathrm{~Hz}), 5.03(1 \mathrm{H}, \mathrm{qq}, J=6.3,6.2 \mathrm{~Hz}), 4.50(1 \mathrm{H}, \mathrm{dd}, J=8.6$, $4.8 \mathrm{~Hz}), 3.82(3 \mathrm{H}, \mathrm{s}), 3.73(1 \mathrm{H}, \mathrm{m}), 3.64(1 \mathrm{H}, \mathrm{m}), 3.61(1 \mathrm{H}, \mathrm{d}, J=16.3 \mathrm{~Hz}), 3.39(1 \mathrm{H}, \mathrm{d}, J=16.3$ $\mathrm{Hz}), 2.94(1 \mathrm{H}, \mathrm{d}, J=16.3 \mathrm{~Hz}), 2.87(1 \mathrm{H}, \mathrm{d}, J=16.3 \mathrm{~Hz}), 2.17(1 \mathrm{H}, \mathrm{m}), 2.06(1 \mathrm{H}, \mathrm{m}), 1.85-1.97$ $(2 \mathrm{H}, \mathrm{m}), 1.36(3 \mathrm{H}, \mathrm{s}), 1.26(3 \mathrm{H}, \mathrm{d}, J=6.3 \mathrm{~Hz}), 1.19(3 \mathrm{H}, \mathrm{d}, J=6.2 \mathrm{~Hz}) ;{ }^{13} \mathbf{C}$ NMR $(126 \mathrm{MHz}$, $\left.\mathrm{CDCl}_{3}\right) \delta \mathrm{C} 175.8,172.1,156.1,143.0,128.3,128.0,117.1,68.1,60.7,55.1,49.7,47.6,44.8$, 40.1, 28.1, 25.6, 25.0, 21.8, 21.7; HRMS (APCI) m/z: $[\mathrm{M}+\mathrm{H}]^{+}$calculated for $\left[\mathrm{C}_{20} \mathrm{H}_{28} \mathrm{O}_{4} \mathrm{~N}\right]^{+}$ 346.2013, found 346.2016; IR (neat) $\tilde{v}=2976,2937,2877,1734,1625,1592,1485,1401,1372$, $1265,1185,1108,1076,922,767,729,707 \mathrm{~cm}^{-1}$. 
${ }^{1} \mathrm{H}$ NMR (500 MHz, $\mathrm{CDCl}_{3}, \mathrm{ppm}$ ) for Compound 6

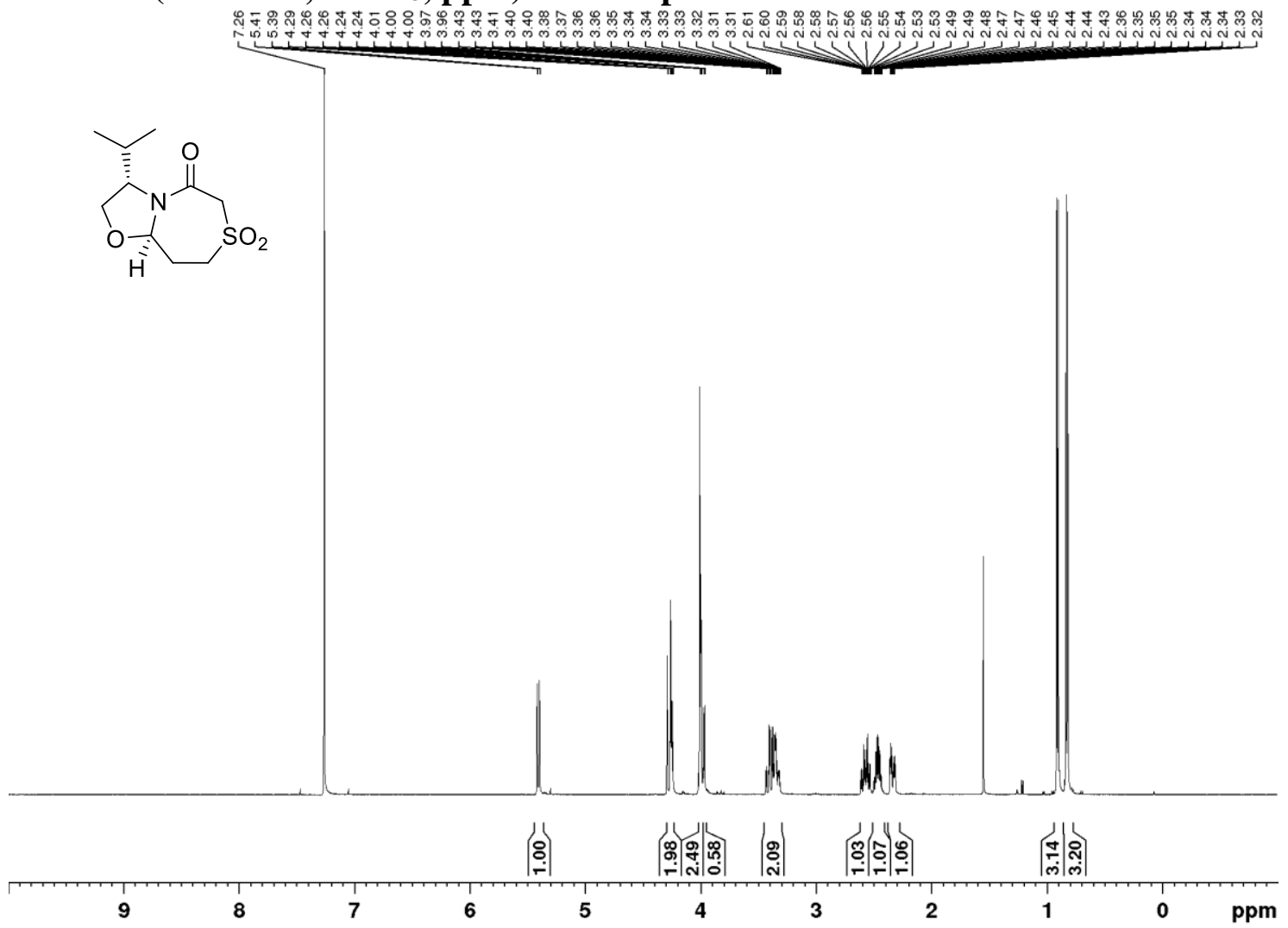

${ }^{13} \mathrm{C}$ NMR (126 MHz, $\mathrm{CDCl}_{3}$, ppm) for Compound 6
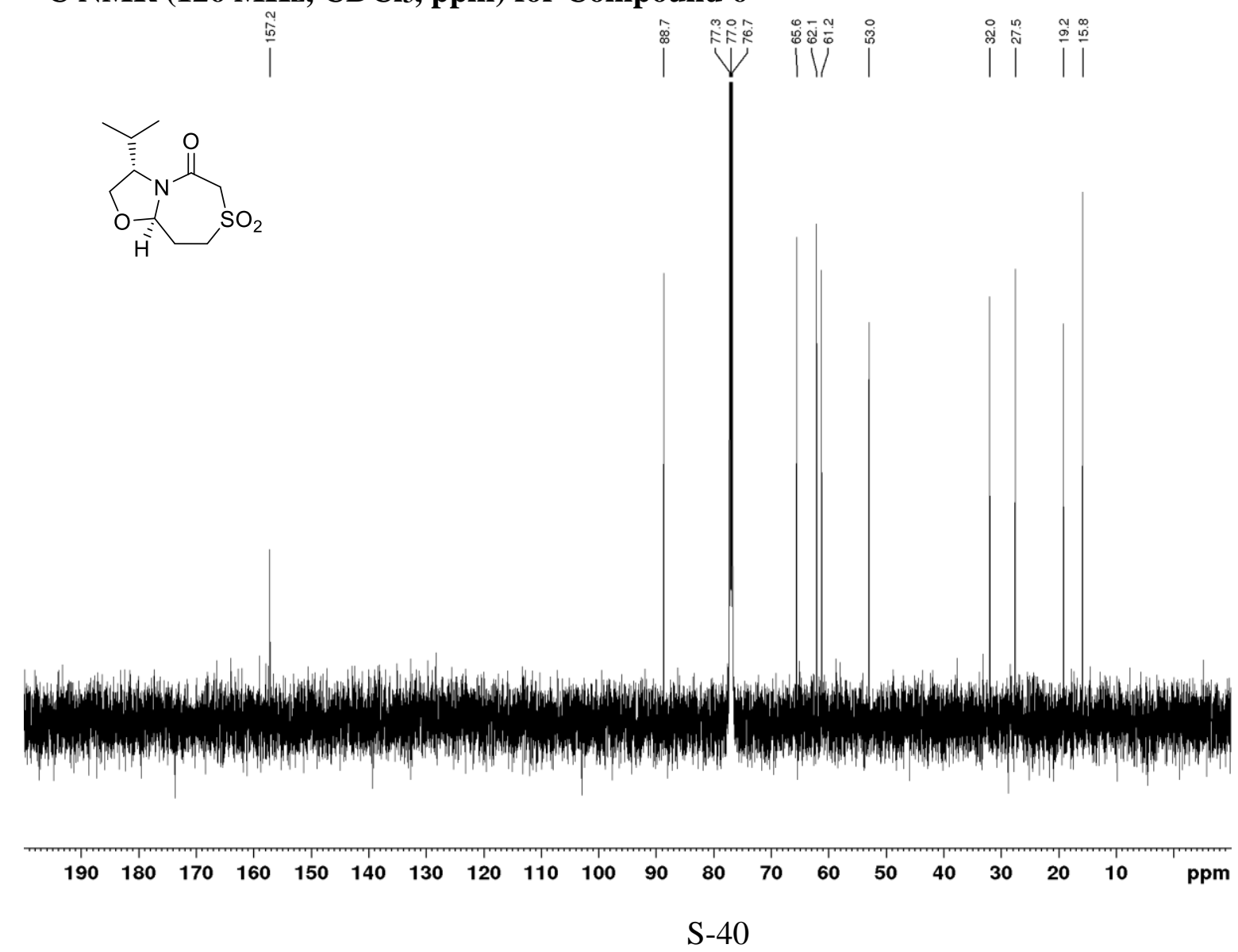
${ }^{1}$ H NMR (500 MHz, DMSO- $d 6$, ppm) for Compound 6

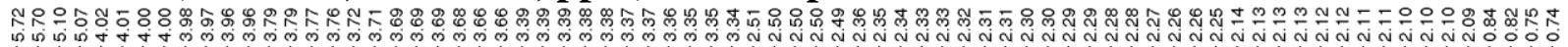<smiles>CC(C)C1COC2CCCCC21</smiles>

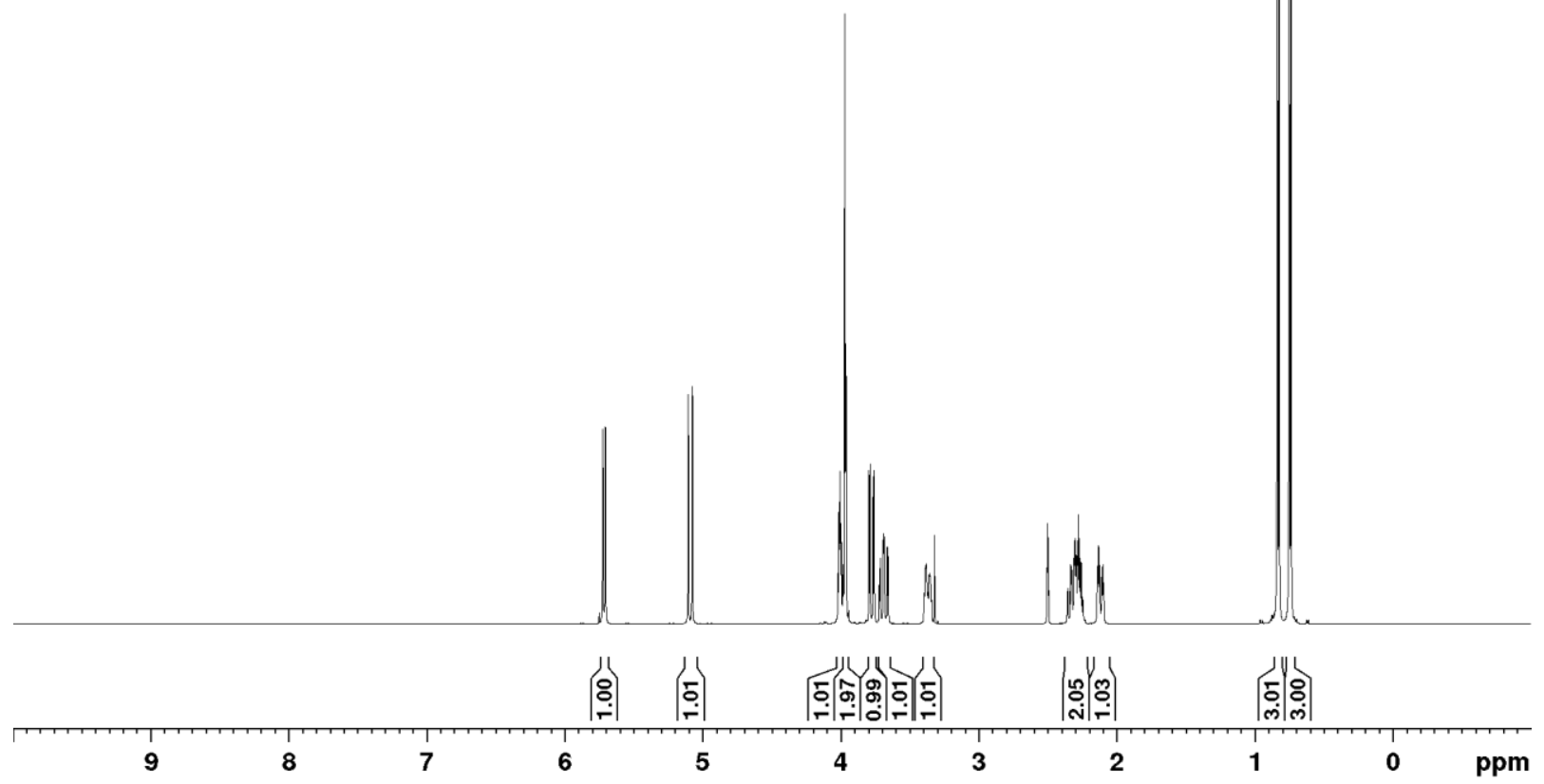

${ }^{13} \mathrm{C}$ NMR (126 MHz, DMSO-d $\left.d_{6}, \mathrm{ppm}\right)$ for Compound 6

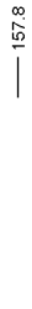<smiles>CC(C)C1COC2CCCCC21</smiles>
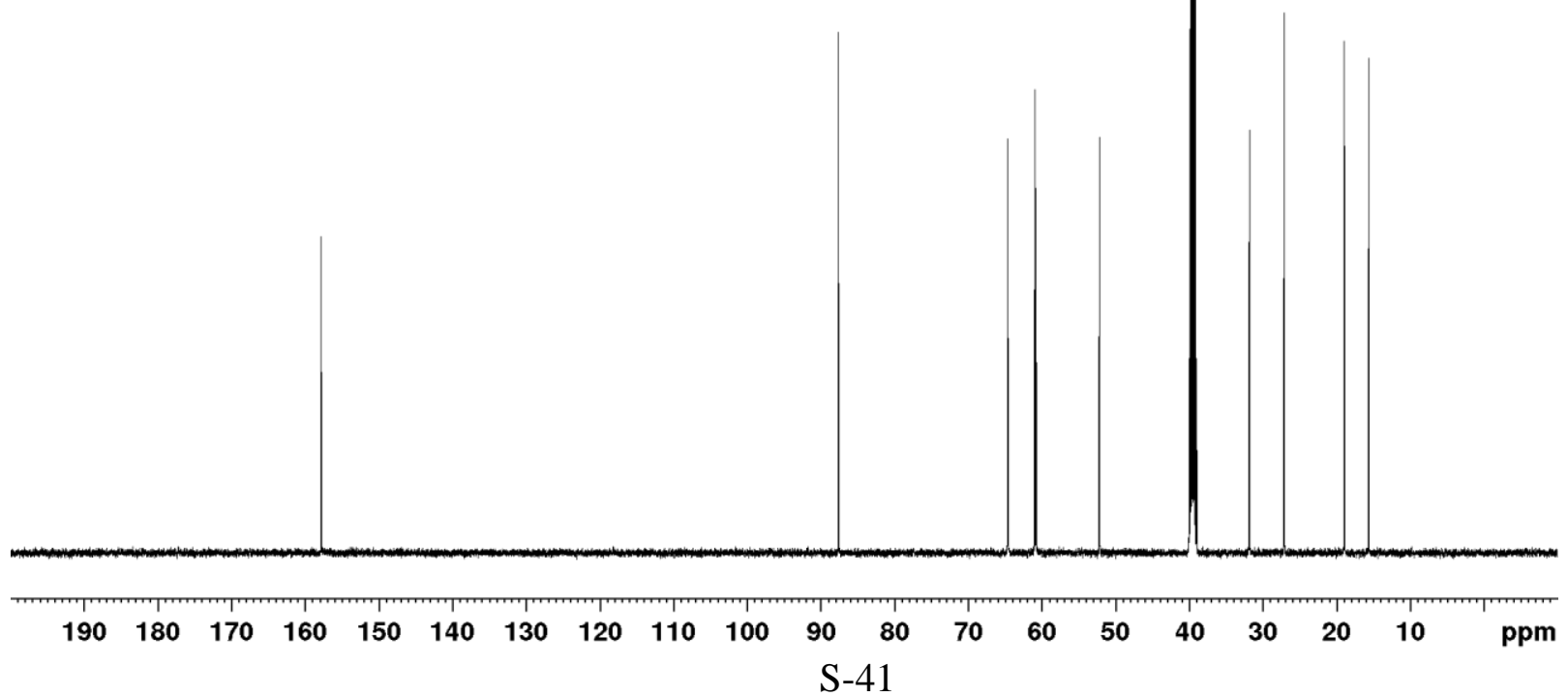
${ }^{1} \mathrm{H}$ NMR (500 MHz, CDCl3, ppm) for Compound 12

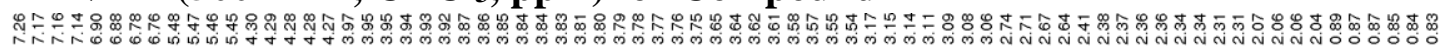

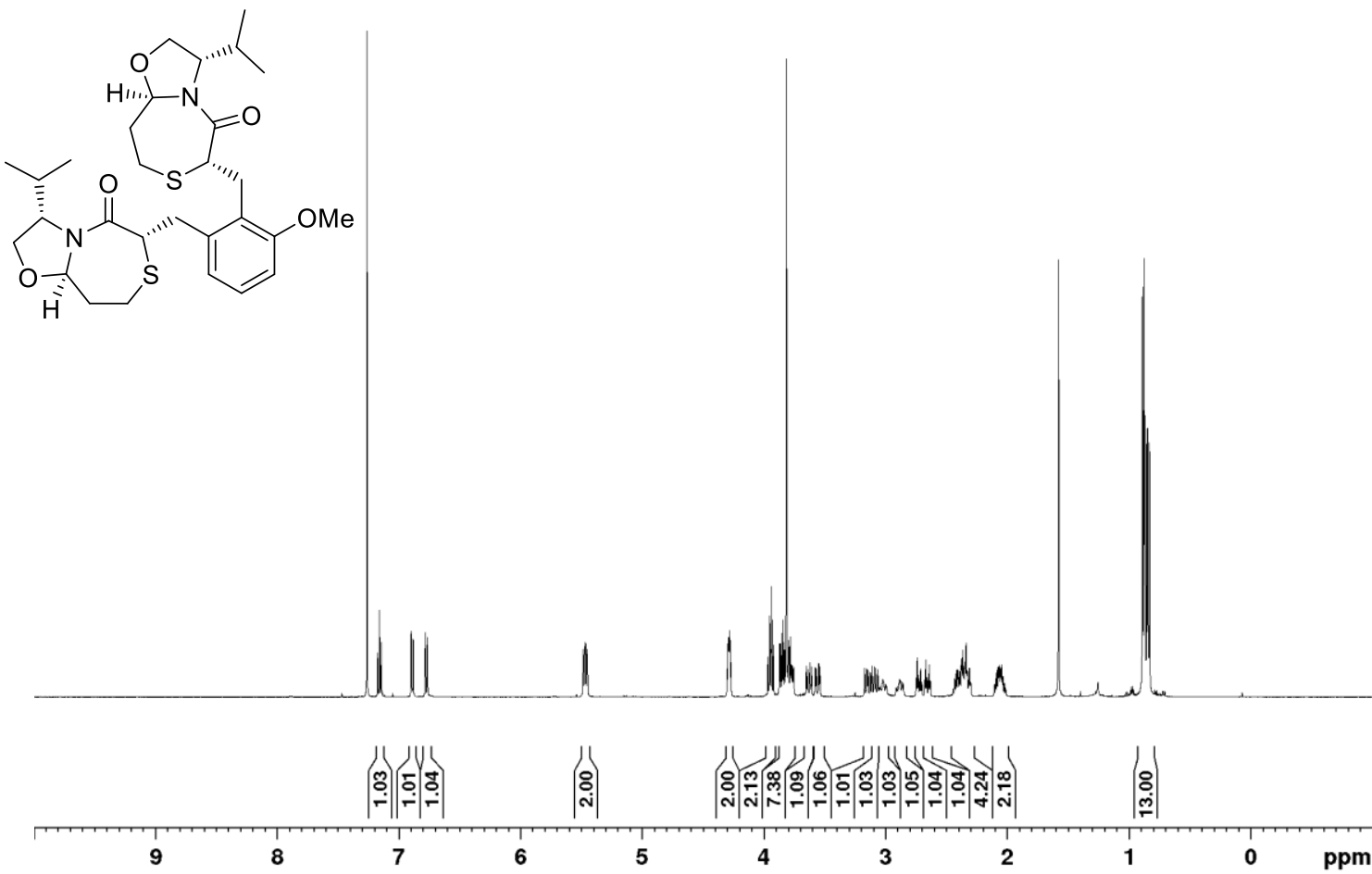

${ }^{13} \mathrm{C}$ NMR (126 MHz, CDCl3, ppm) for Compound 12

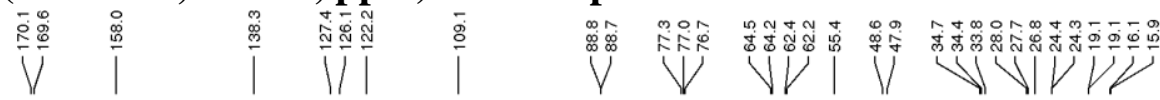<smiles>COc1cccc(C[C@H]2SCC[C@@H]3OC[C@H](C(C)C)N3C2=O)c1C[C@@H]1SCC[C@@H]2OC[C@@H](C(C)C)N2C1=O</smiles>

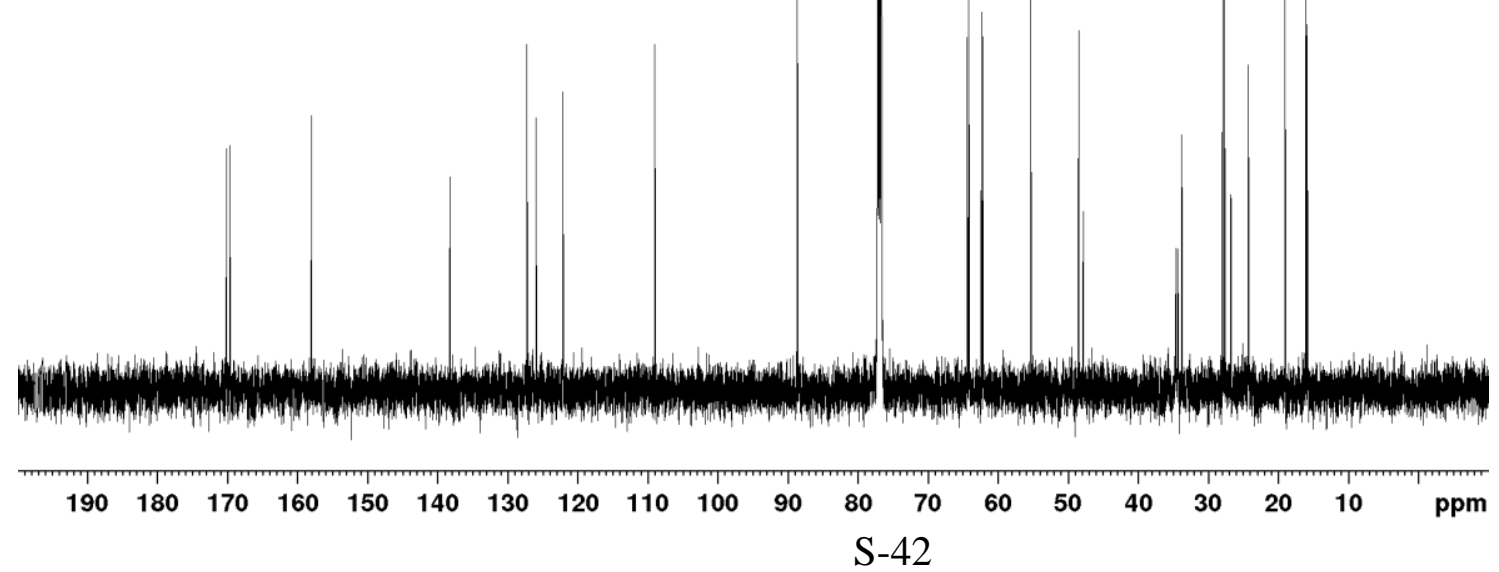


HSQC (500 MHz, $\mathrm{CDCl}_{3}$, ppm) for Compound 12

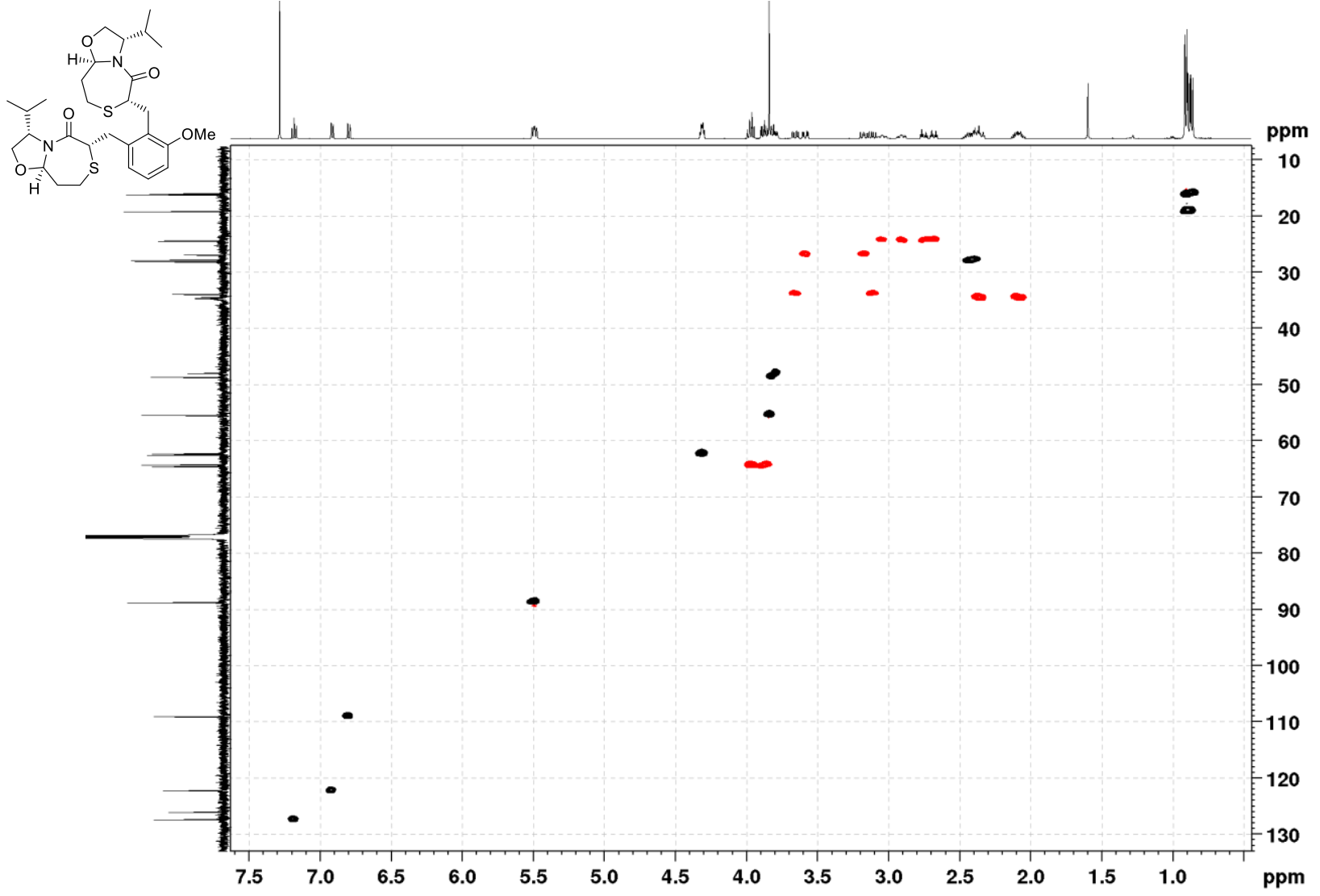

NOESY (500 MHz, CDCl3, ppm) for Compound 12

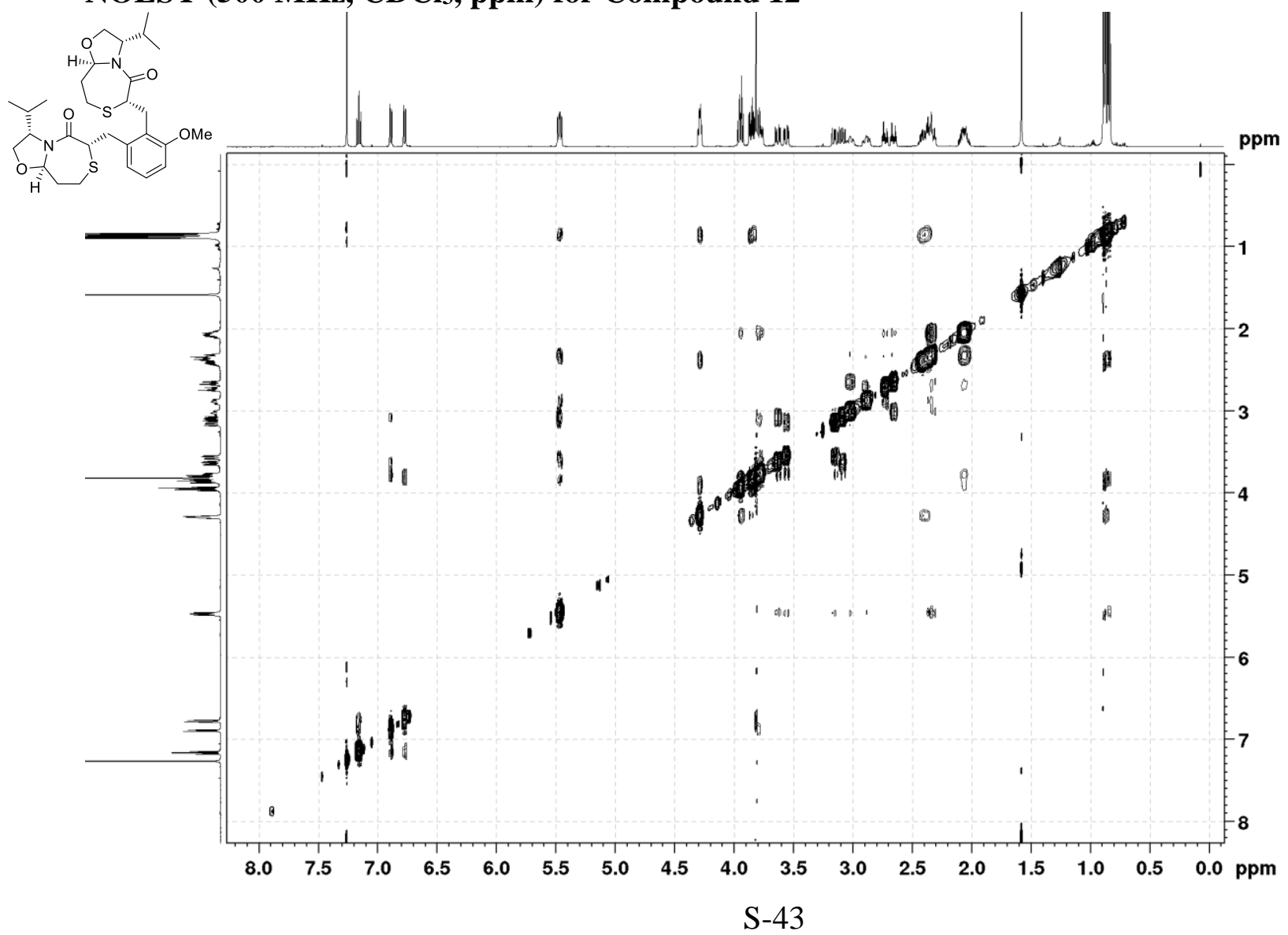


NOE (500 MHz, $\left.\mathrm{CDCl}_{3}, \mathrm{ppm}\right)$ for Compound 12

Vं

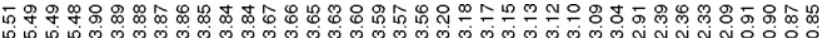

1<smiles>COc1cccc(C[C@H]2SCC[C@H]3OC[C@H](C(C)C)N3C2=O)c1C[C@H]1SCC[C@H]2OC[C@@H](C(C)C)N2C1=O</smiles>

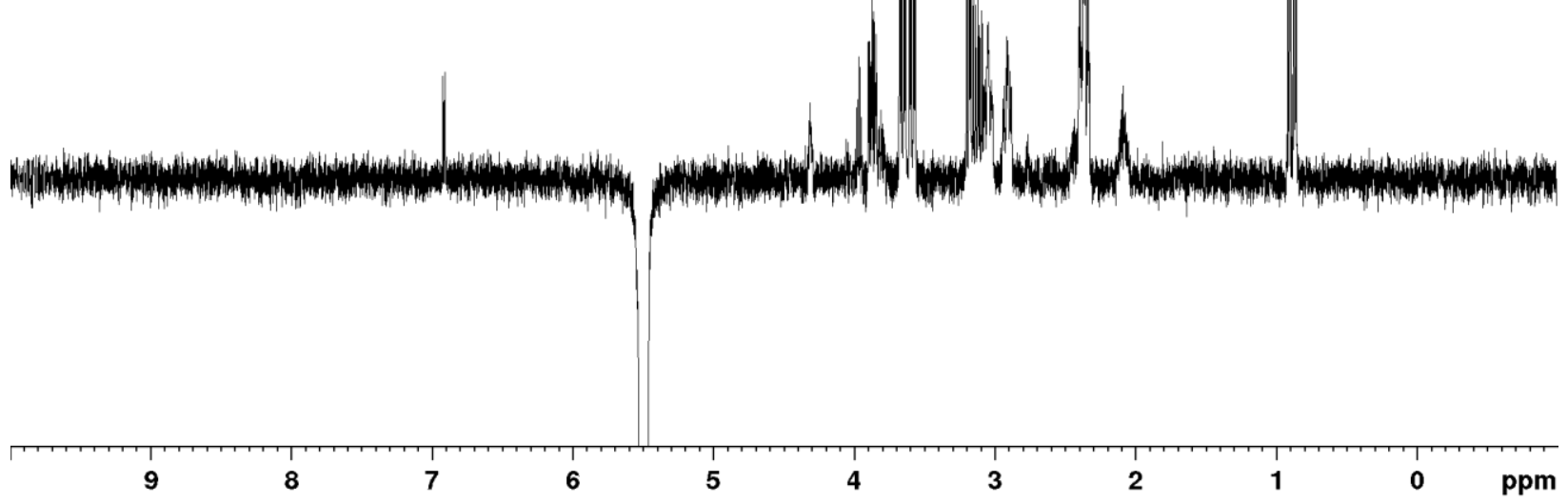

${ }^{1} \mathrm{H}$ NMR (500 MHz, CDCl3, ppm) for Compound $11 \mathrm{f}$

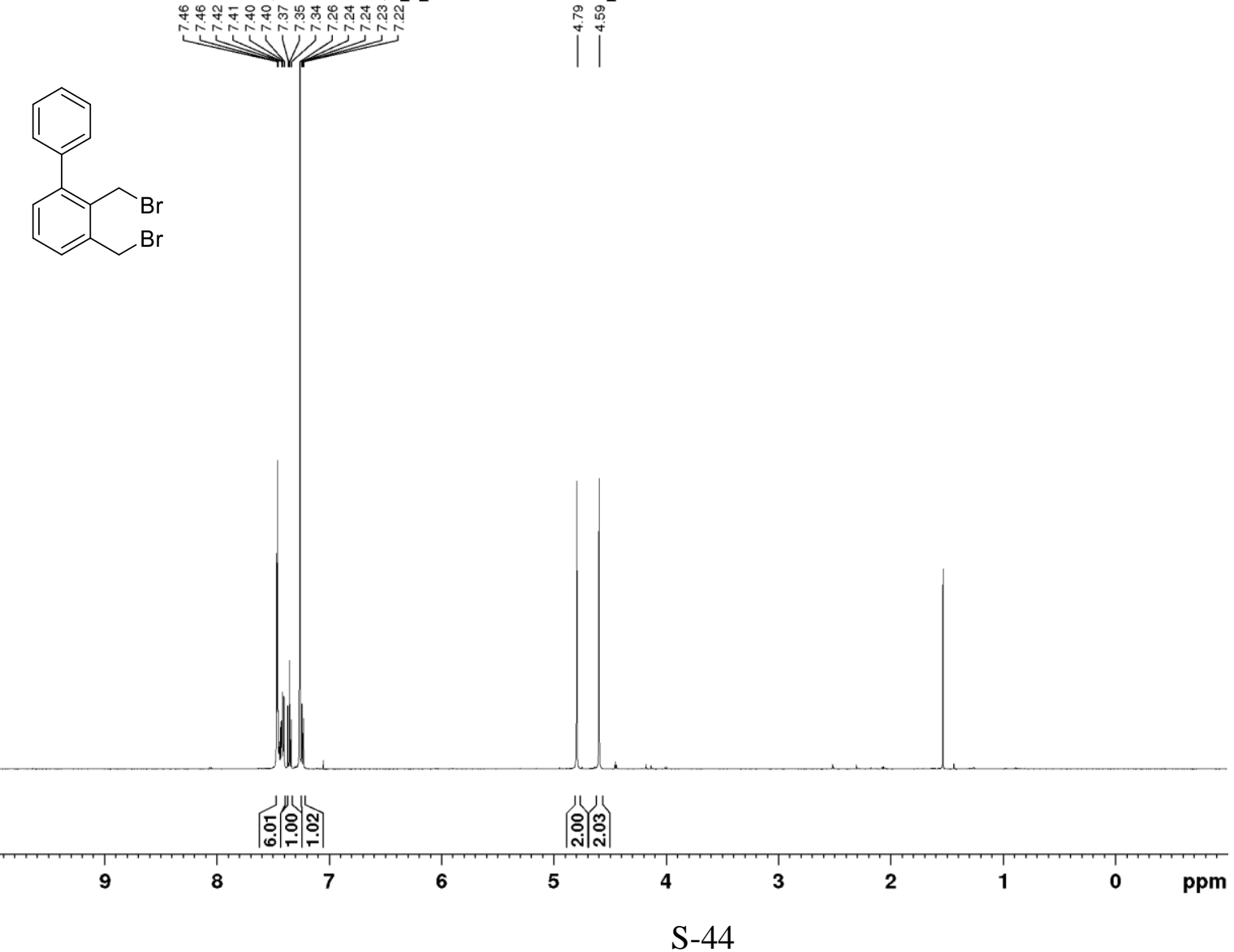




\section{${ }^{13} \mathrm{C}$ NMR (126 $\left.\mathrm{MHz}, \mathrm{CDCl}_{3}, \mathrm{ppm}\right)$ for Compound $11 \mathrm{f}$}

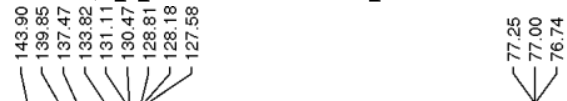<smiles>BrCc1cccc(-c2ccccc2)c1CBr</smiles>

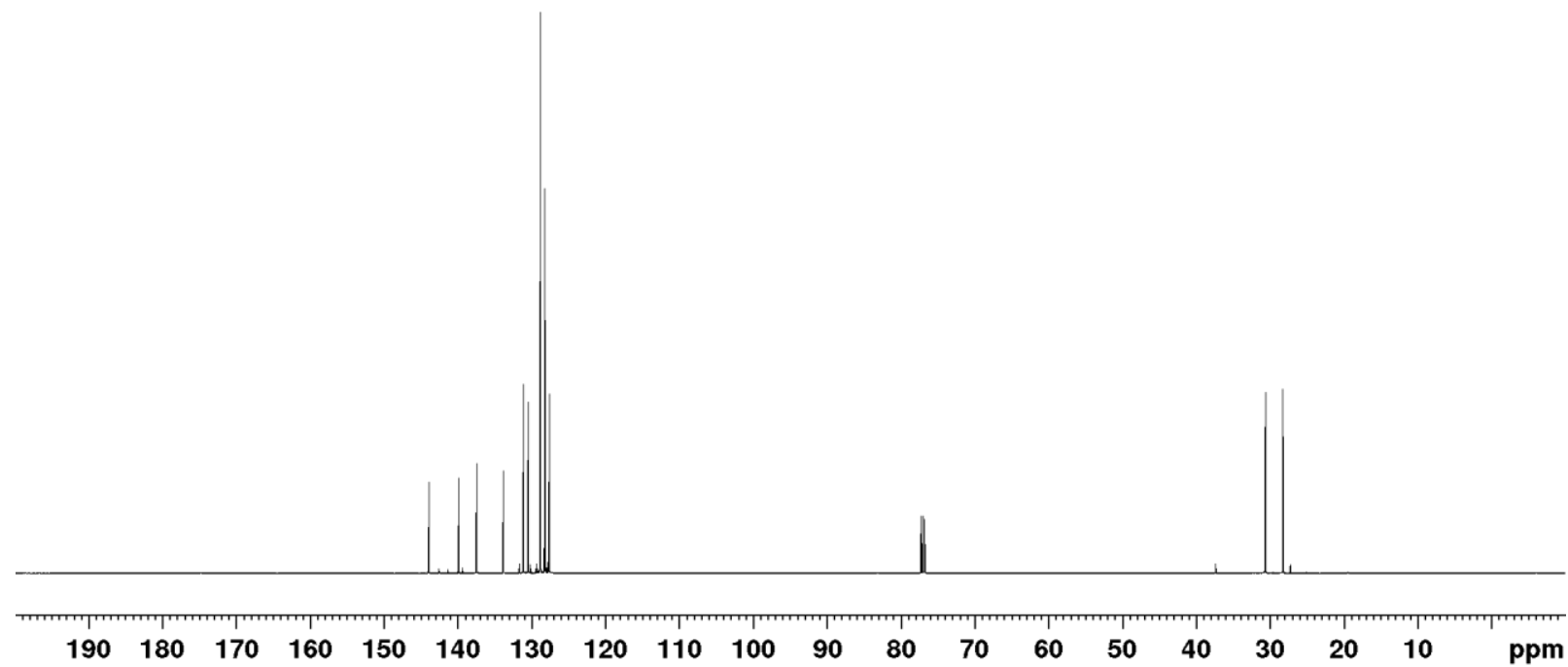

${ }^{1} \mathrm{H}$ NMR (500 MHz, CDCl3, ppm) for Compound $11 \mathrm{~g}$
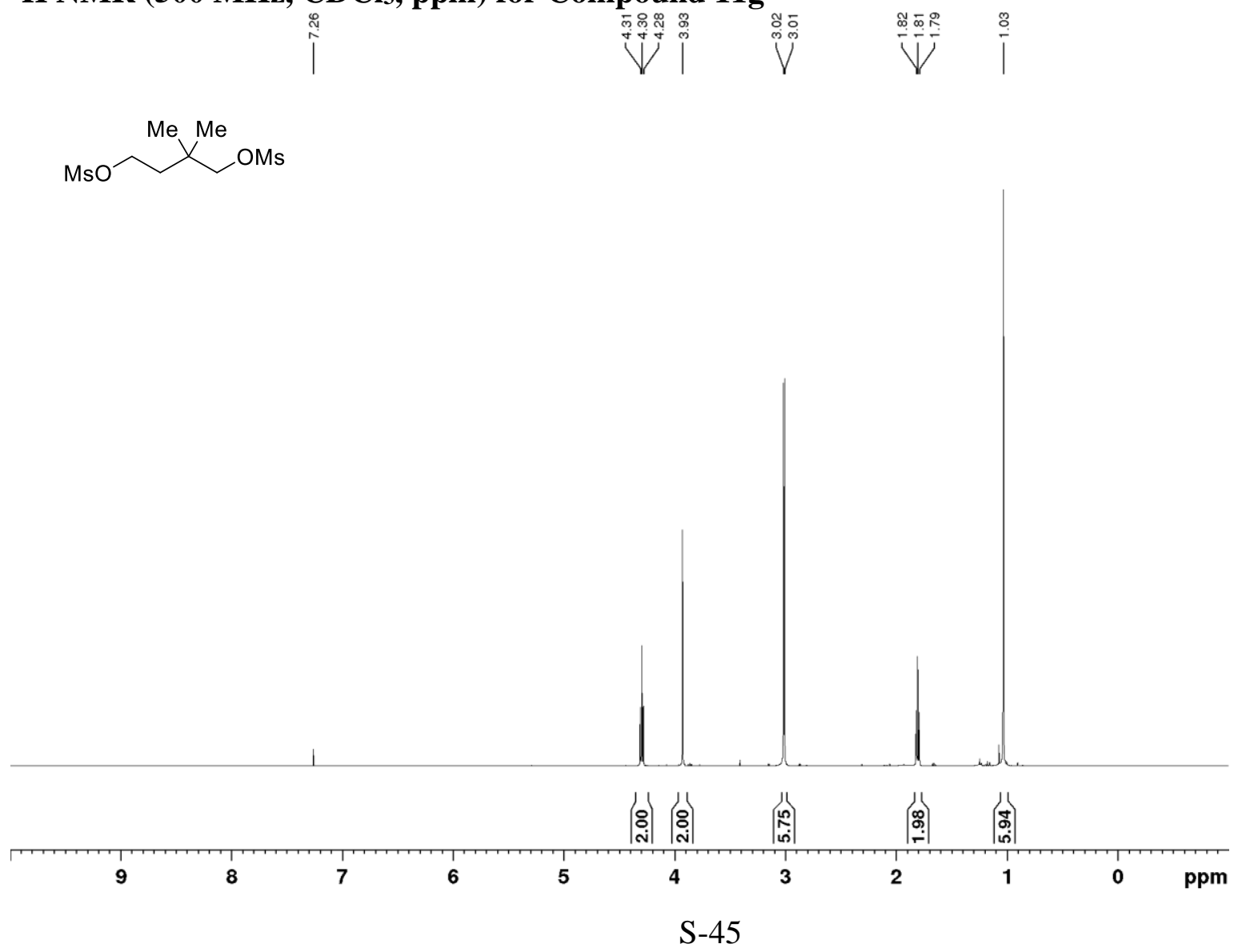
${ }^{13} \mathrm{C}$ NMR (126 MHz, $\left.\mathrm{CDCl}_{3}, \mathrm{ppm}\right)$ for Compound $11 \mathrm{~g}$

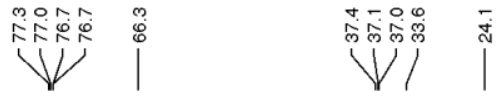

$\overbrace{\mathrm{MsO}}^{\mathrm{Me} O M s}$

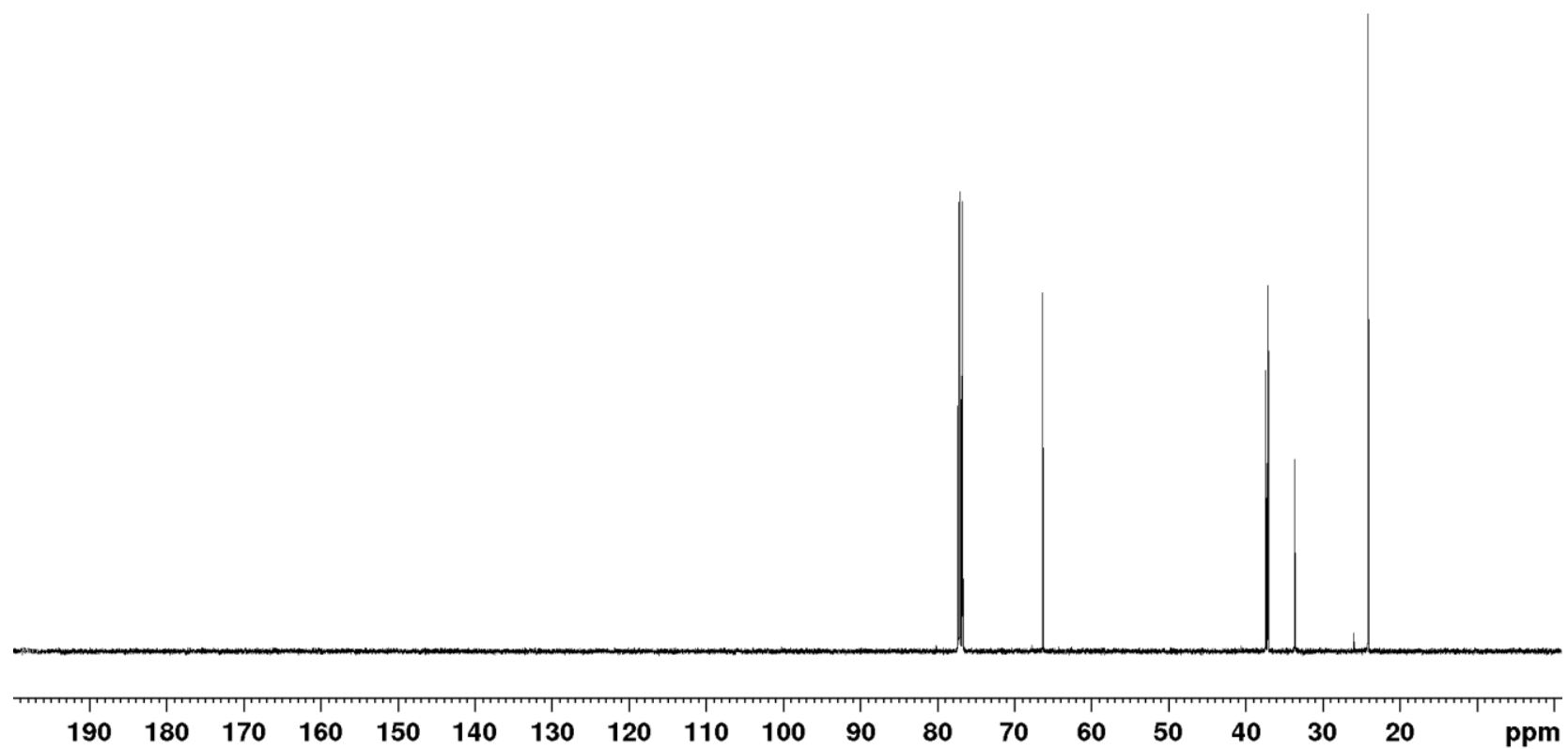

${ }^{1} \mathrm{H}$ NMR (500 MHz, CDCl3, ppm) for Compound 13a

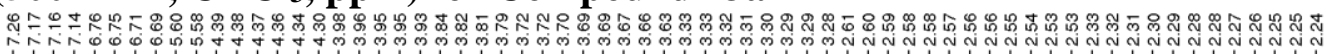<smiles>COc1cccc2c1C[C@@]1(C2)C(=O)N2[C@H](CC[C@@H]1C(C)C)OC[C@H]2O</smiles>

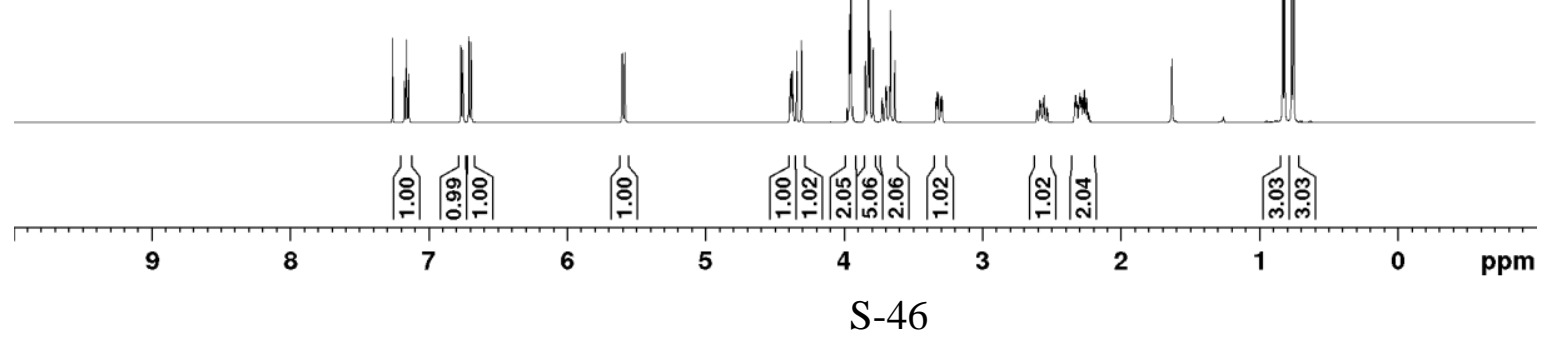


${ }^{13} \mathrm{C}$ NMR (126 MHz, $\mathrm{CDCl}_{3}$, ppm) for Compound 13a

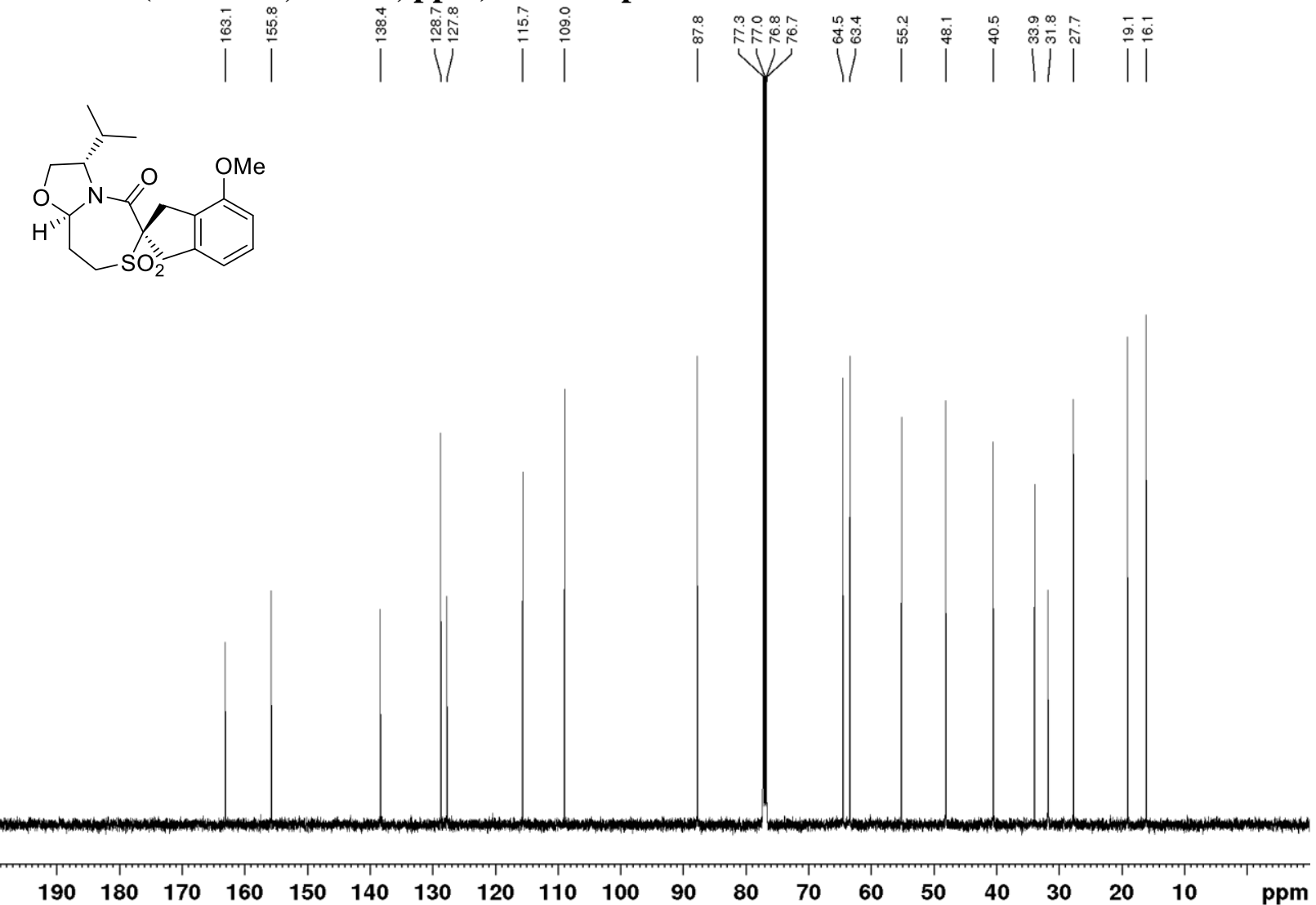

$\operatorname{COSY}\left(500 \mathrm{MHz}, \mathrm{CDCl}_{3}, \mathrm{ppm}\right)$ for Compound 13a

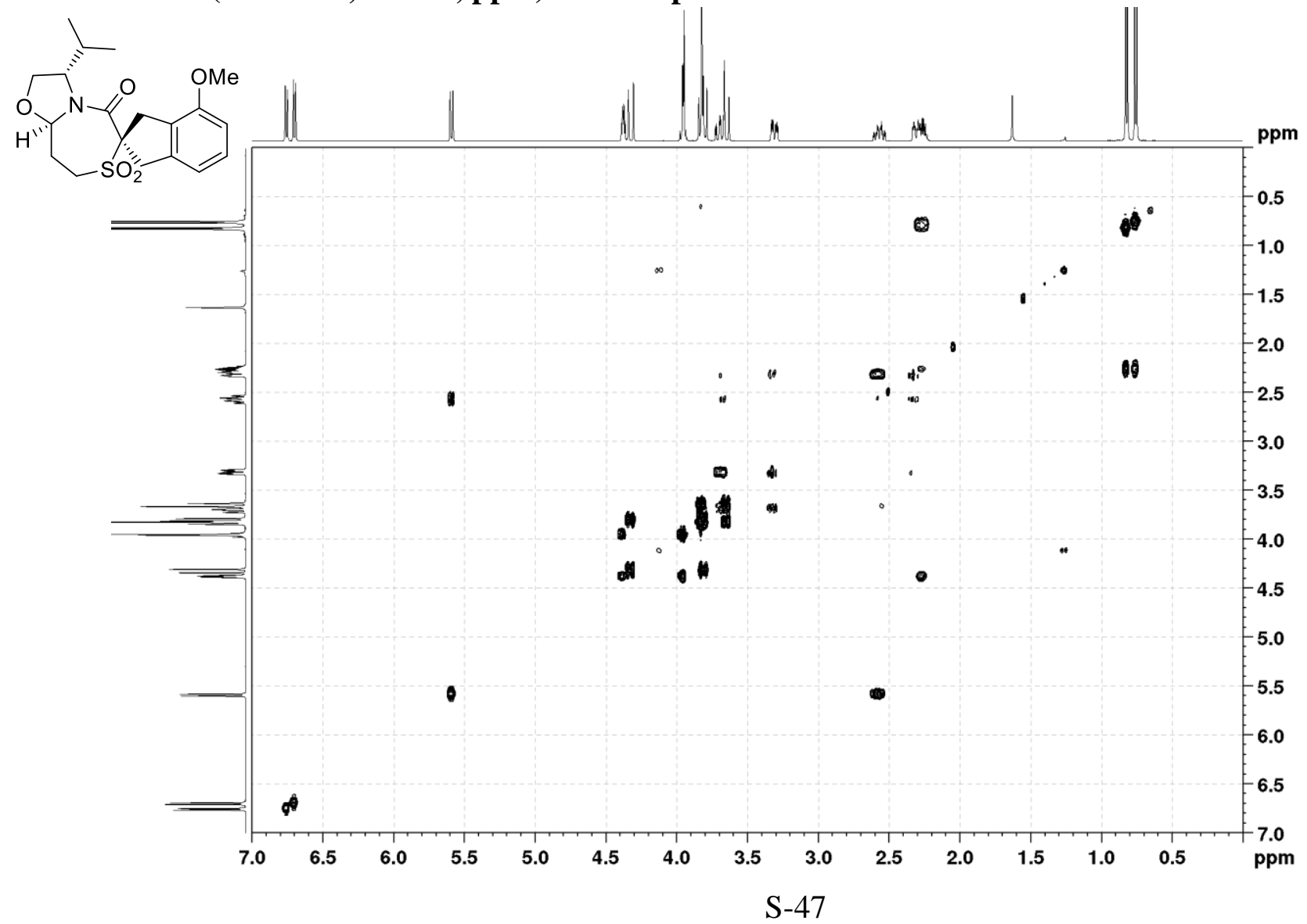


HSQC (500 MHz, $\mathrm{CDCl}_{3}$, ppm) for Compound 13a

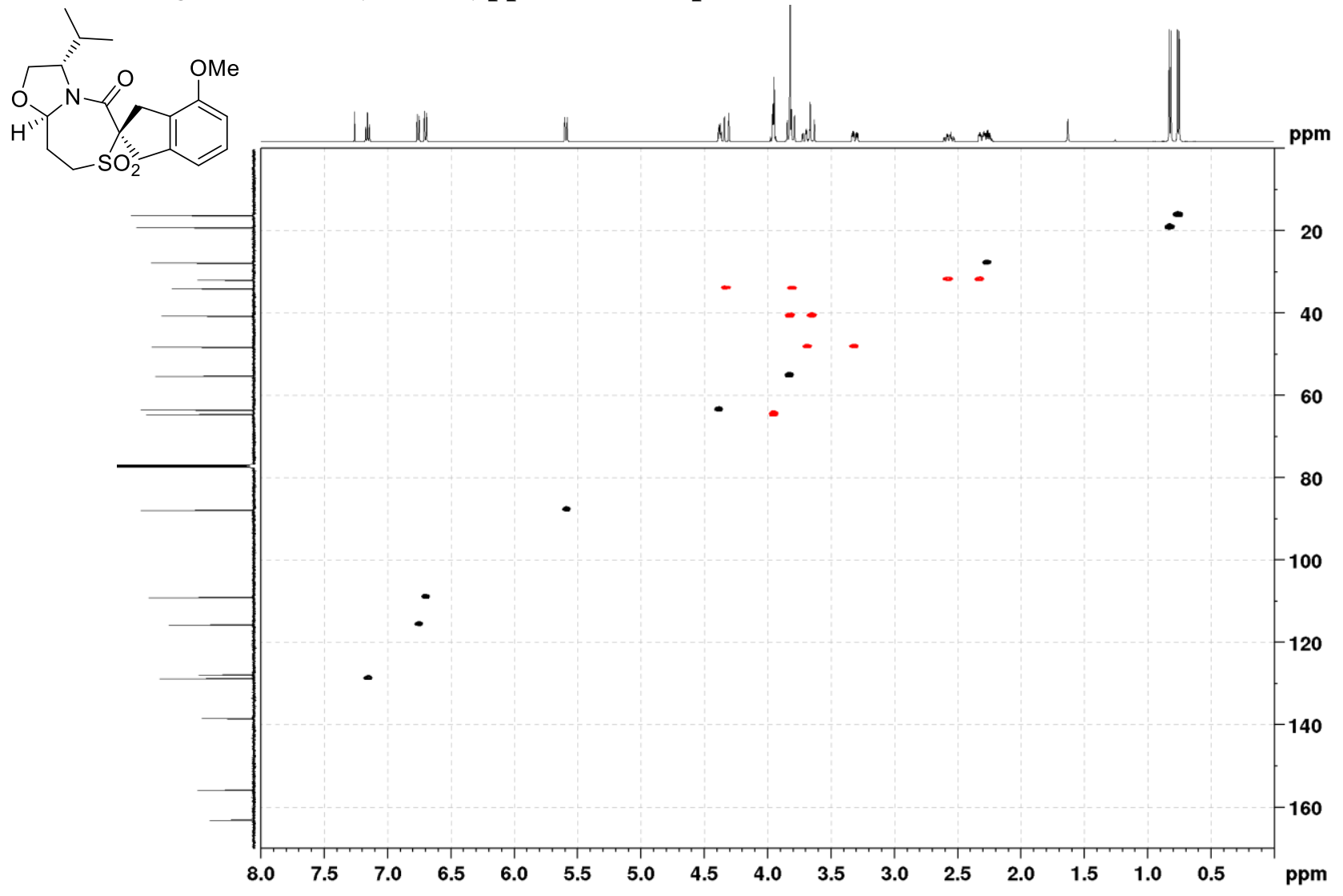

HMBC (500 MHz, $\mathrm{CDCl}_{3}$, ppm) for Compound 13a

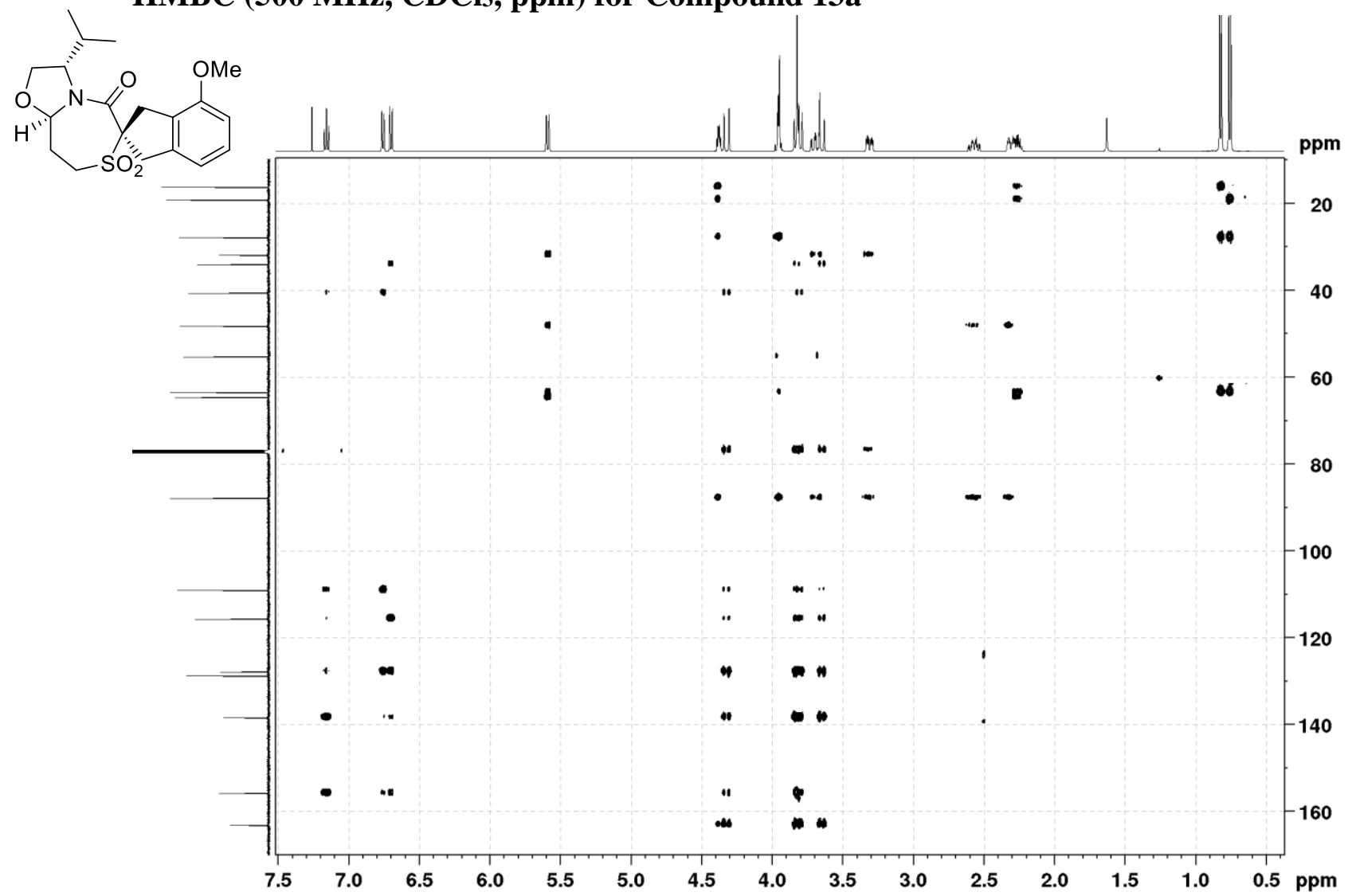

S-48 
NOESY (500 MHz, CDCl3, ppm) for Compound 13a

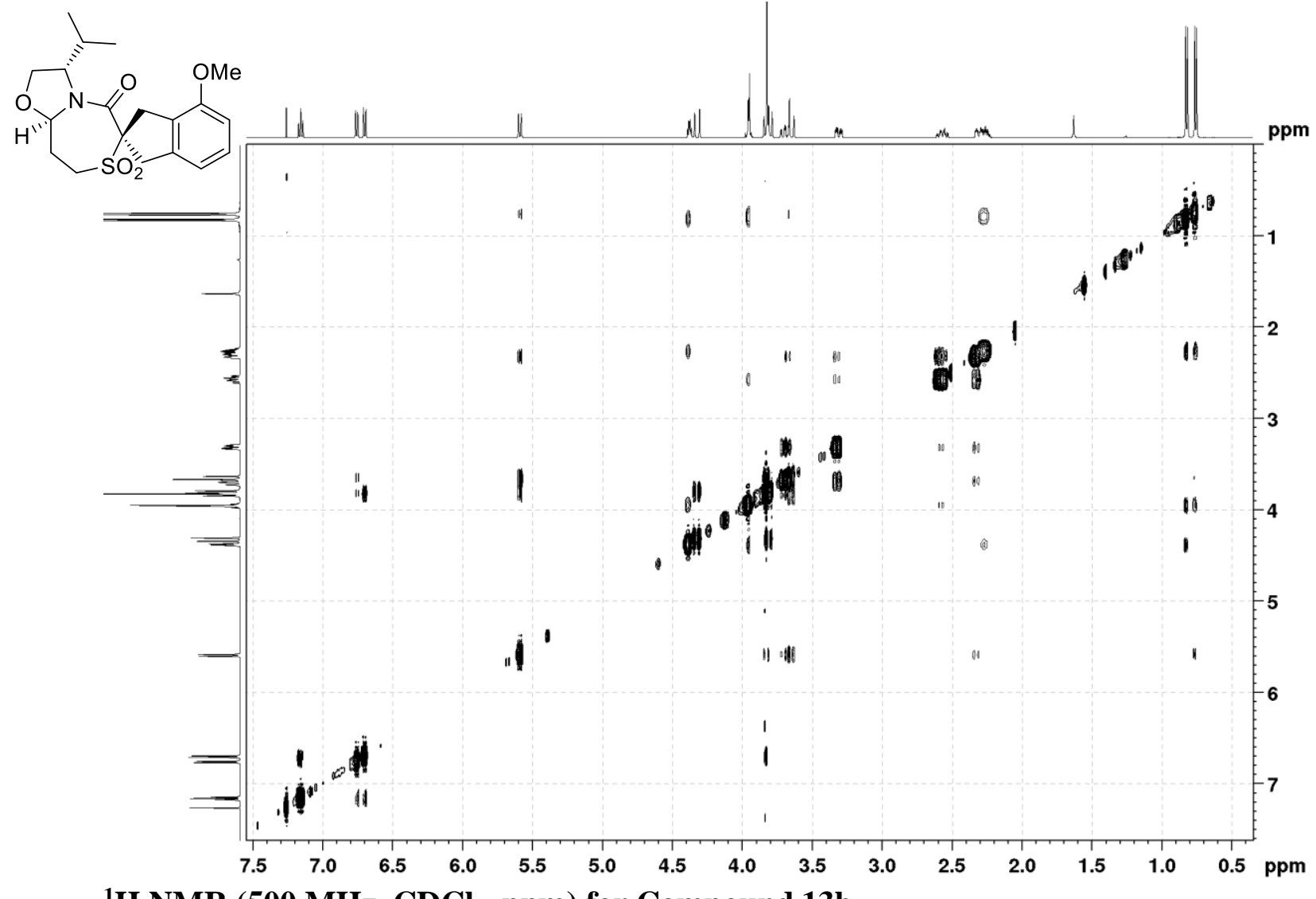

${ }^{1} \mathrm{H}$ NMR (500 MHz, CDCl3, ppm) for Compound 13b

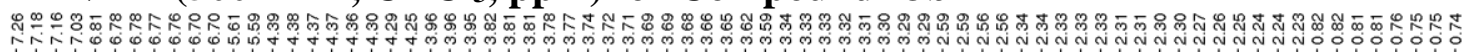<smiles>COc1ccc2c(c1)C[C@]1(C2)C(=O)N2[C@H](CC[C@@H]1C(C)C)OC[C@H]2OC</smiles><smiles>COc1ccc2c(c1)C[C@@]1(C2)C(=O)N2[C@H](CC[S@@]1=O)OC[C@H]2C(C)C</smiles>

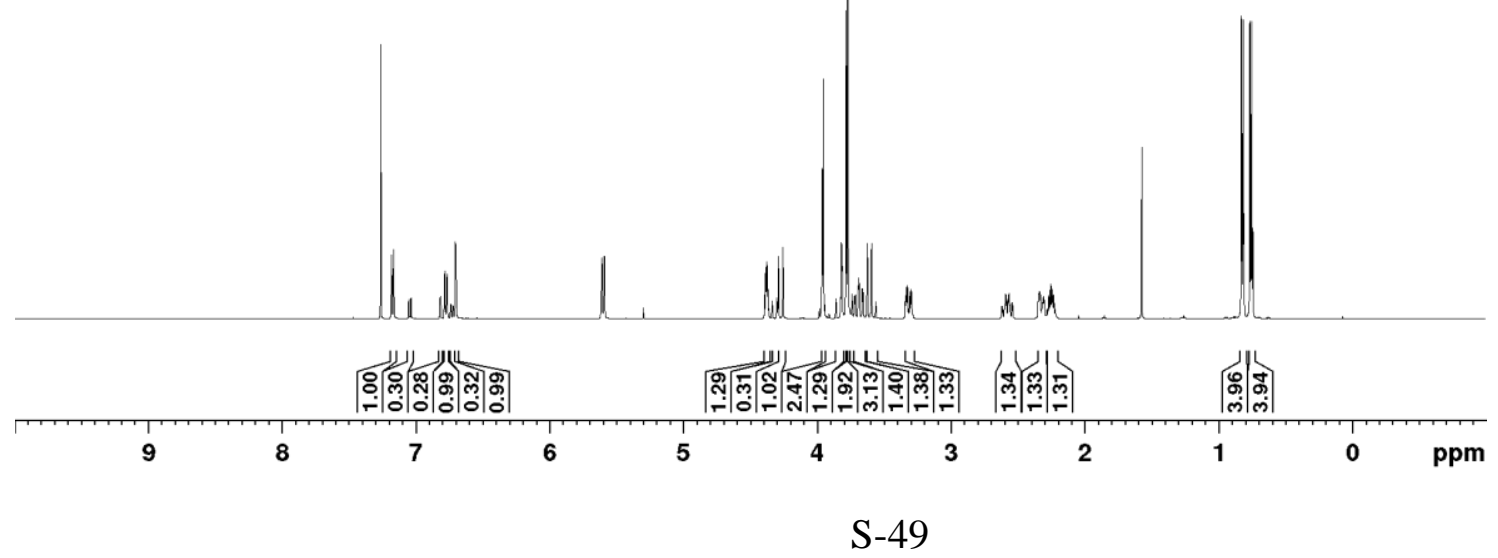


${ }^{13} \mathrm{C}$ NMR (126 MHz, $\mathrm{CDCl}_{3}$, ppm) for Compound 13b

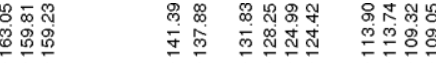

IV II IV VV
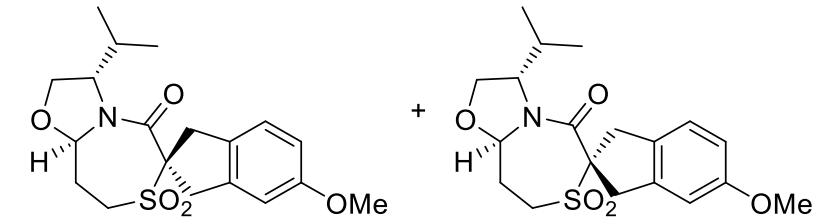

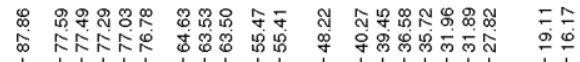

| Y Y Y V V |

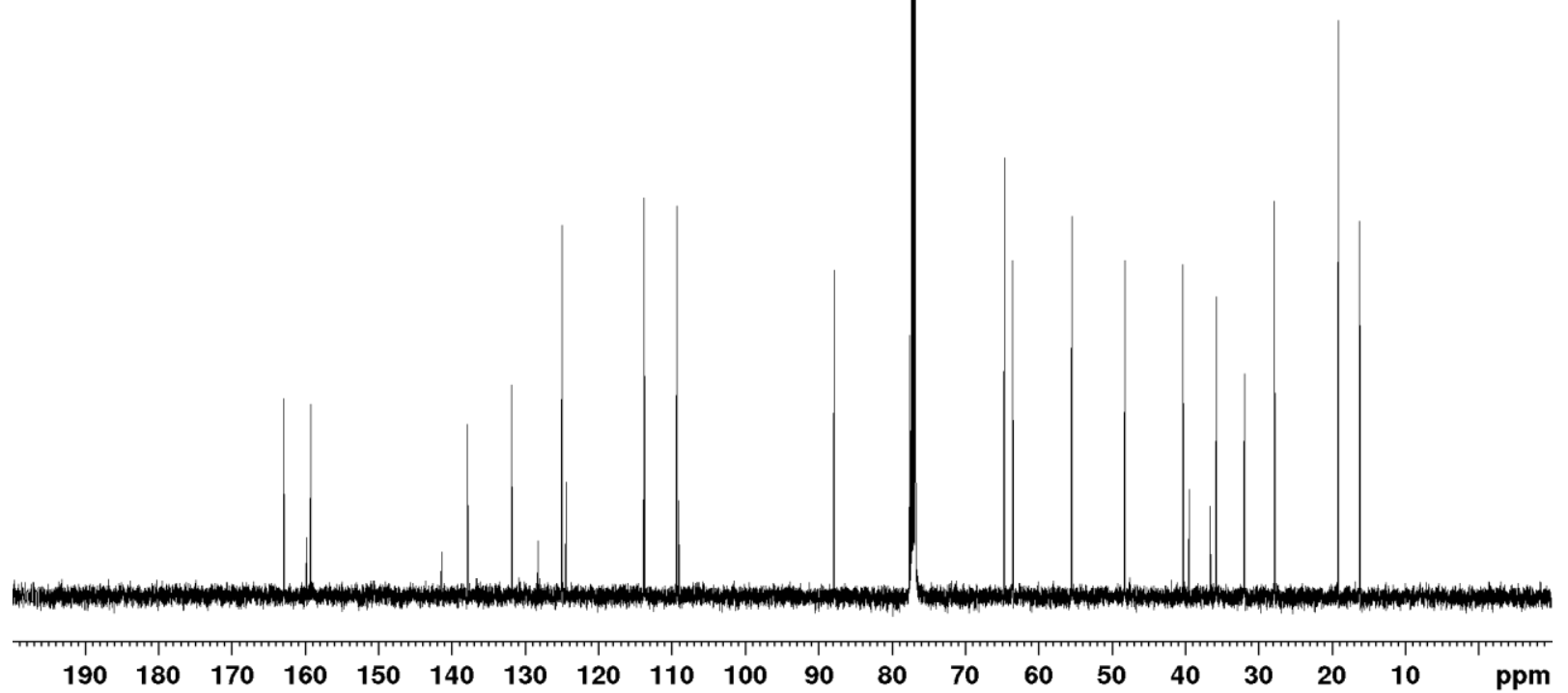

COSY (500 MHz, $\mathrm{CDCl}_{3}, \mathrm{ppm}$ ) for Compound 13b

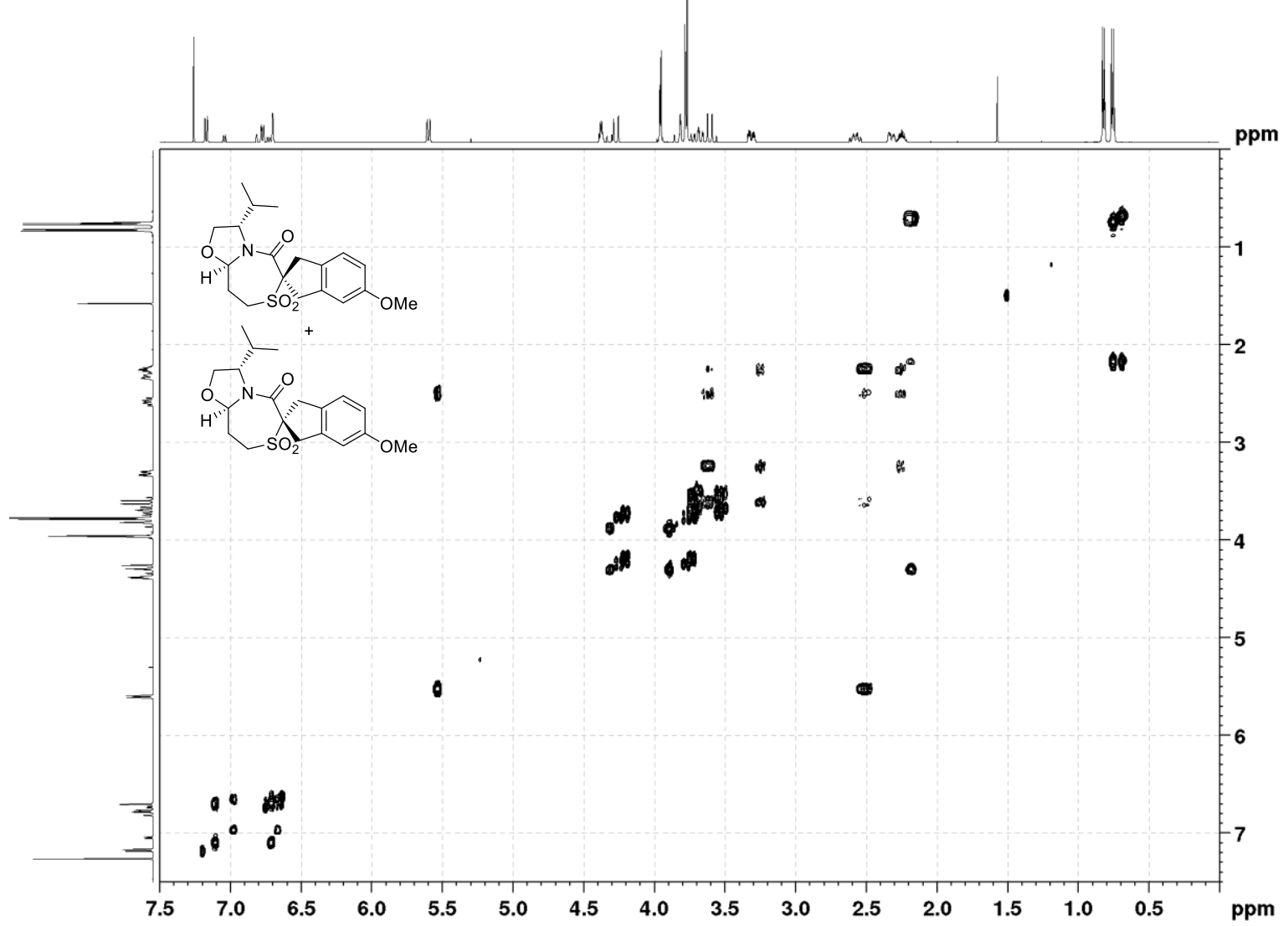

S-50 
HSQC (500 MHz, $\mathrm{CDCl}_{3}, \mathrm{ppm}$ ) for Compound 13b

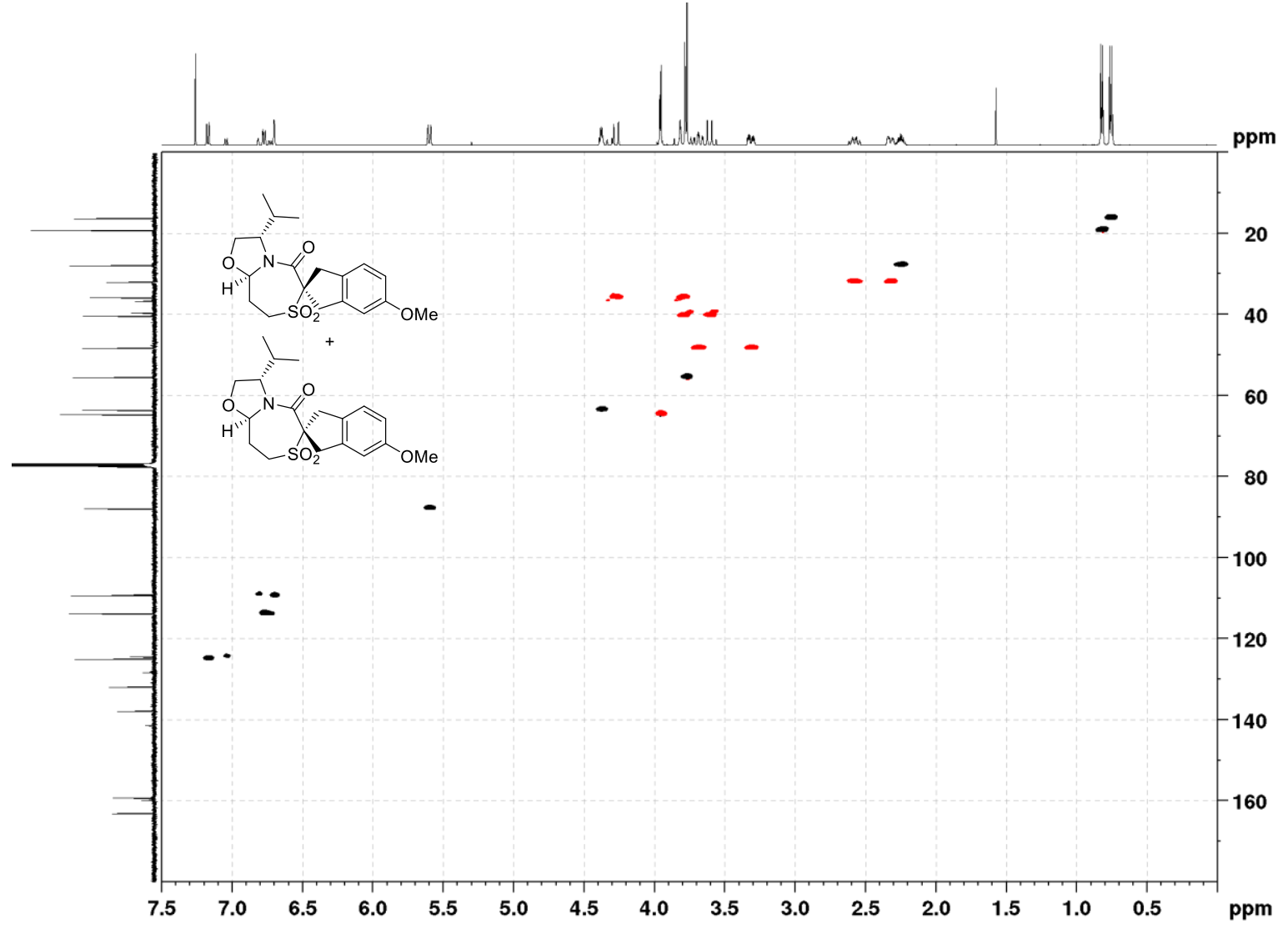

HMBC (500 MHz, CDCl3, ppm) for Compound 13b

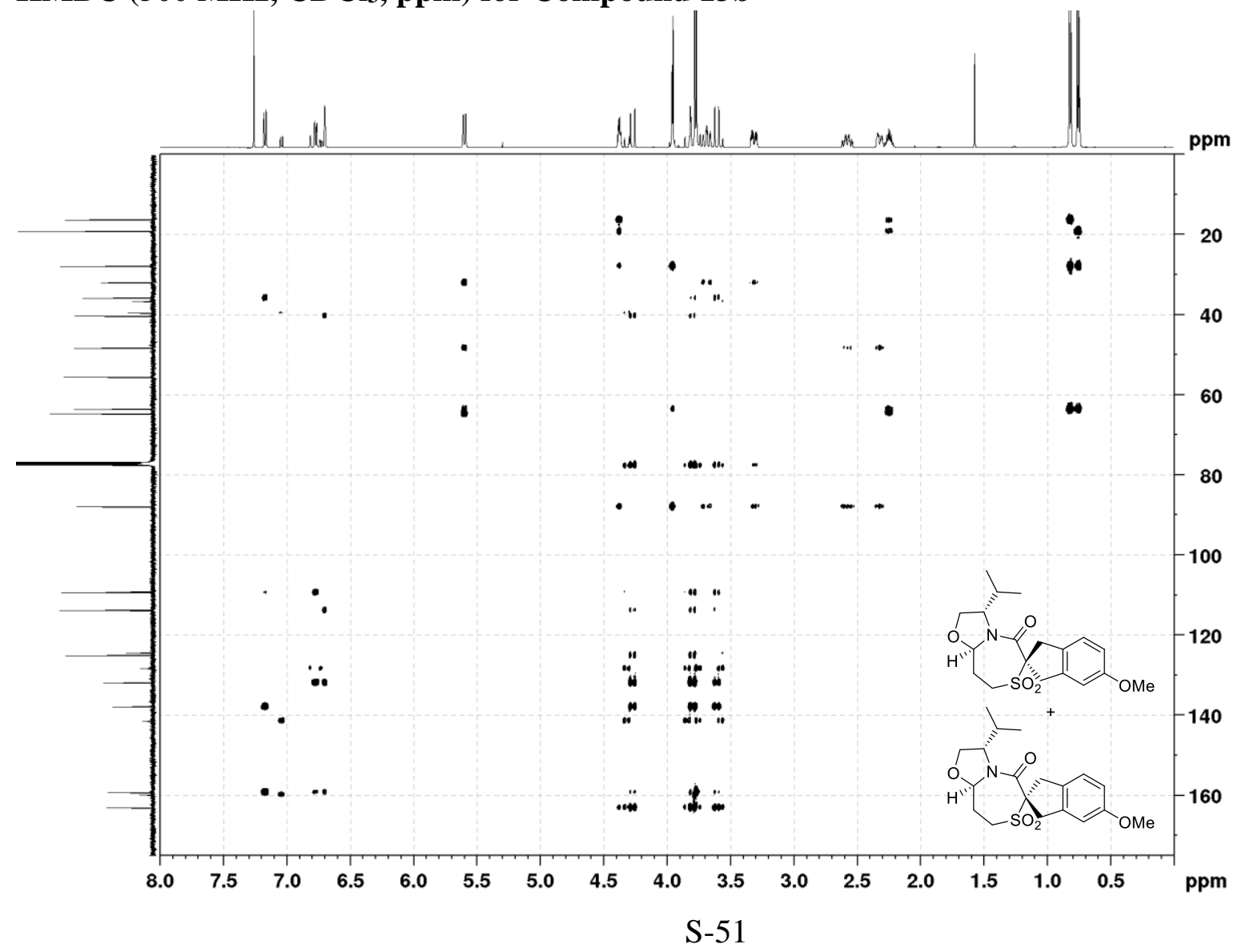


NOESY (500 MHz, CDCl3, ppm) for Compound 13b

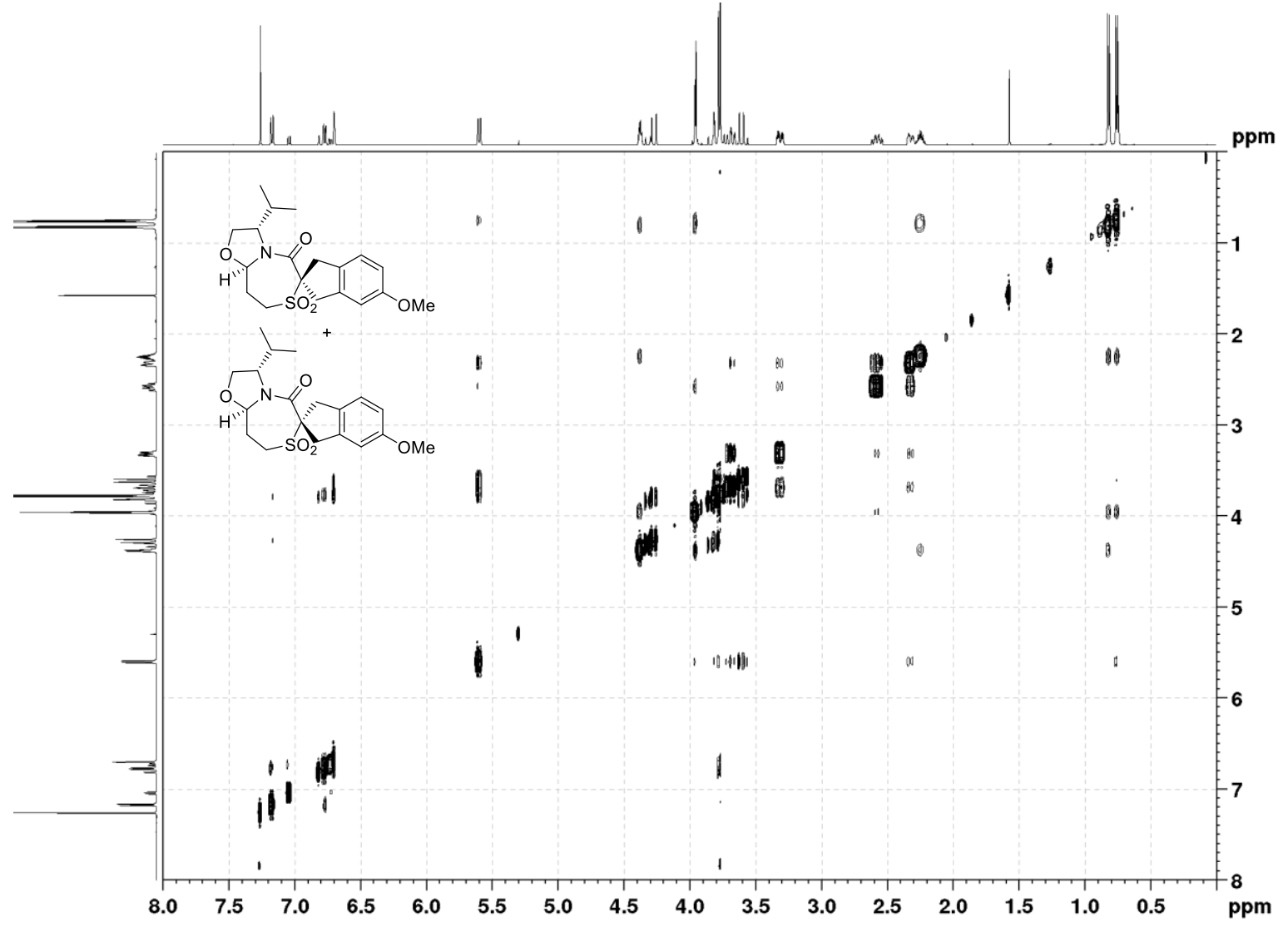

${ }^{1} \mathrm{H}$ NMR (500 MHz, CDCl3, ppm) for Compound 13c

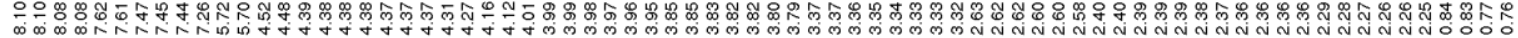

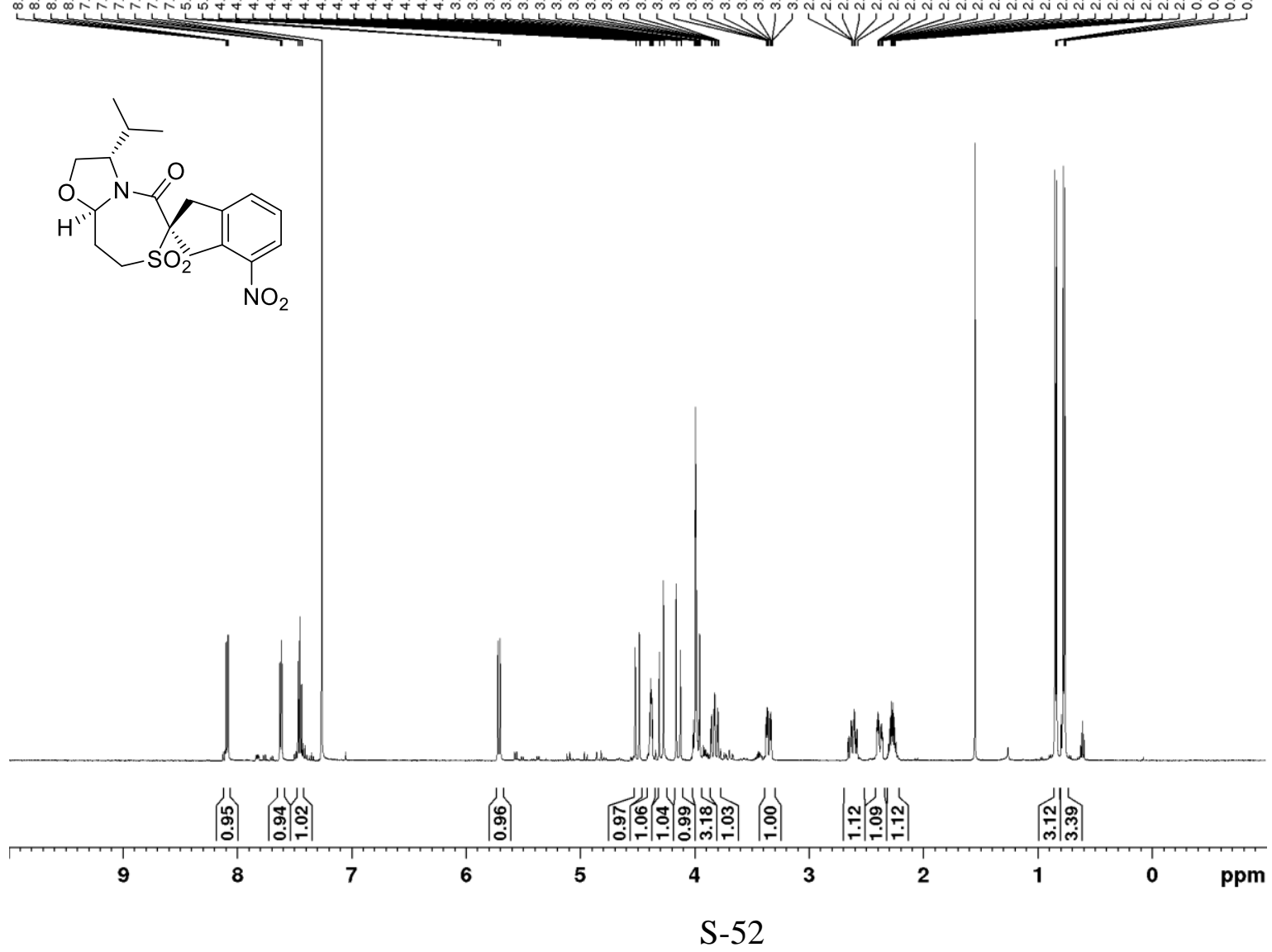


${ }^{13} \mathrm{C}$ NMR (126 MHz, $\left.\mathrm{CDCl}_{3}, \mathrm{ppm}\right)$ for Compound $13 \mathrm{c}$

ind

$\mathrm{H}^{\prime}$<smiles>CC(C)[C@H]1CO[C@H]2CCS(=O)(=O)c3cccc([N+](=O)[O-])c3C21C</smiles>

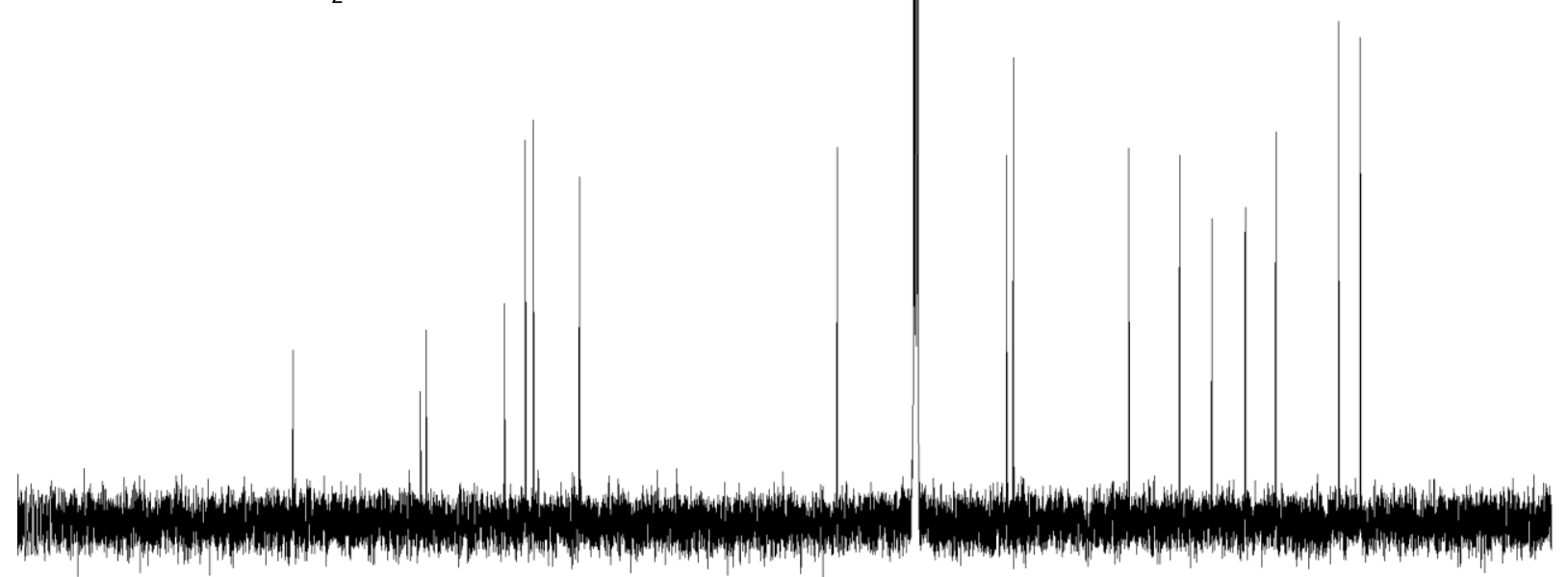

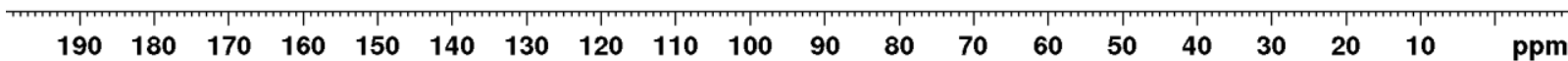

HSQC (500 MHz, CDCl3, ppm) for Compound 13c

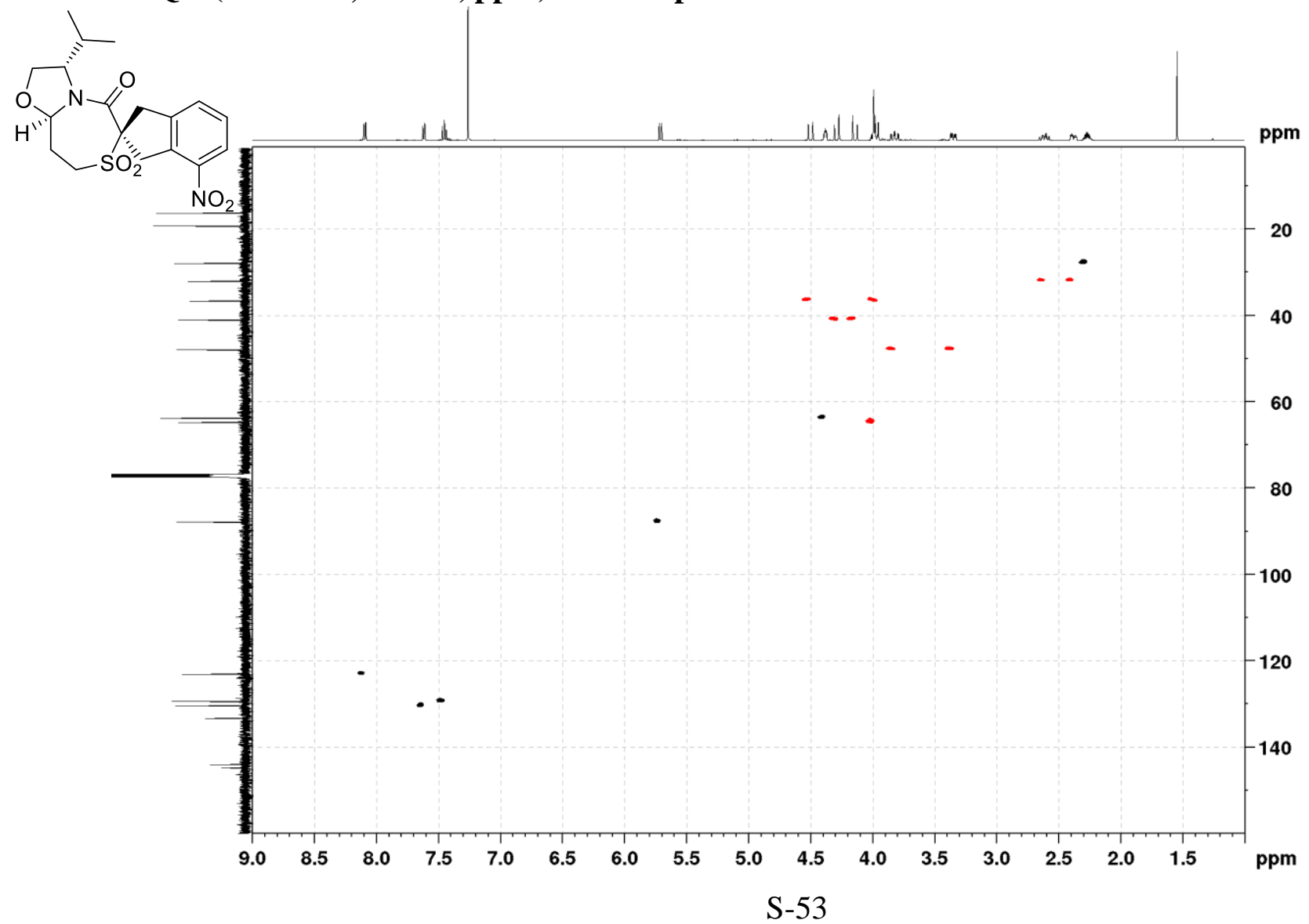


HMBC (500 MHz, $\mathrm{CDCl}_{3}$, ppm) for Compound 13c
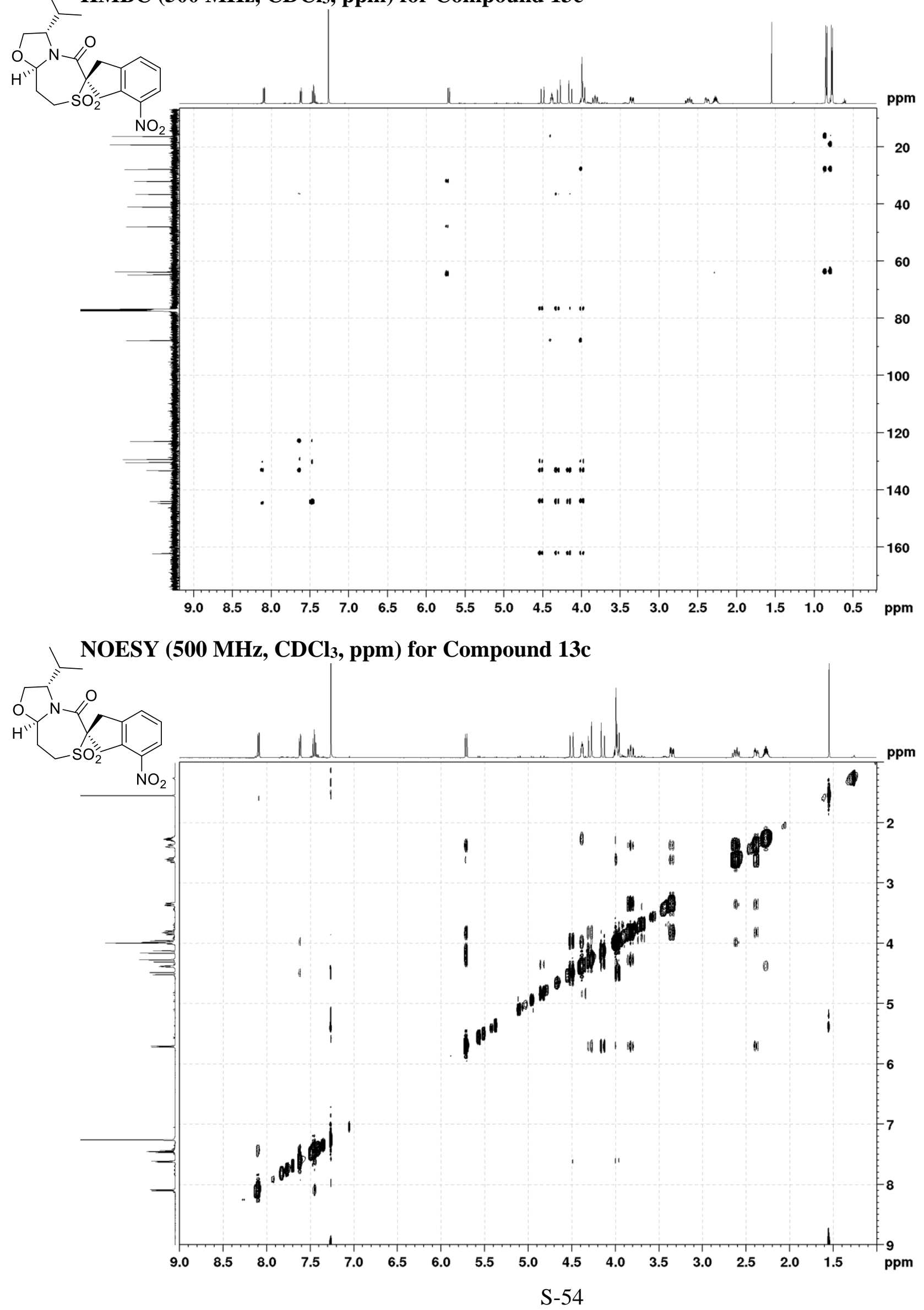
${ }^{1} \mathrm{H}$ NMR (500 MHz, CDCl3, ppm) for Compound 13d

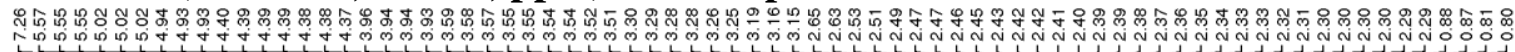<smiles>C=C1CC[C@@]2(C1)OCC[C@H]1OC[C@@H](C(C)C)N1C2=O</smiles>

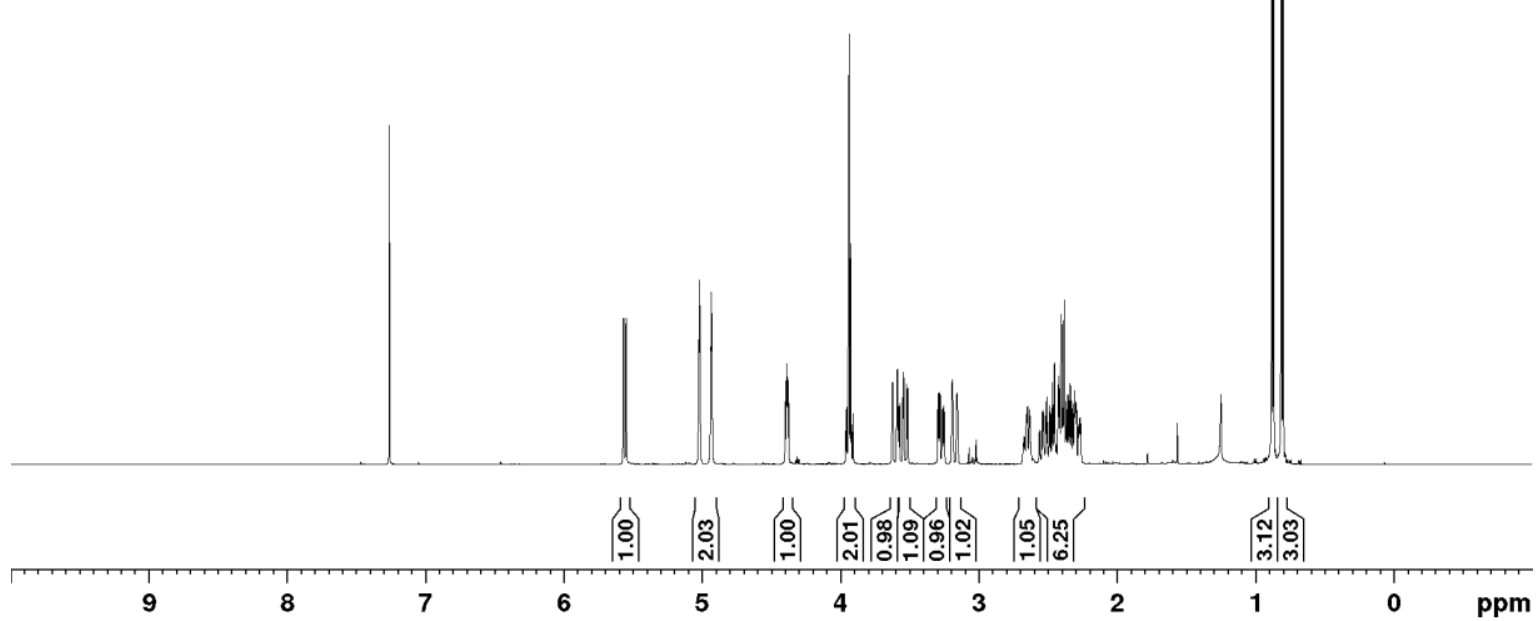

${ }^{13} \mathrm{C}$ NMR (126 MHz, CDCl3, ppm) for Compound 13d
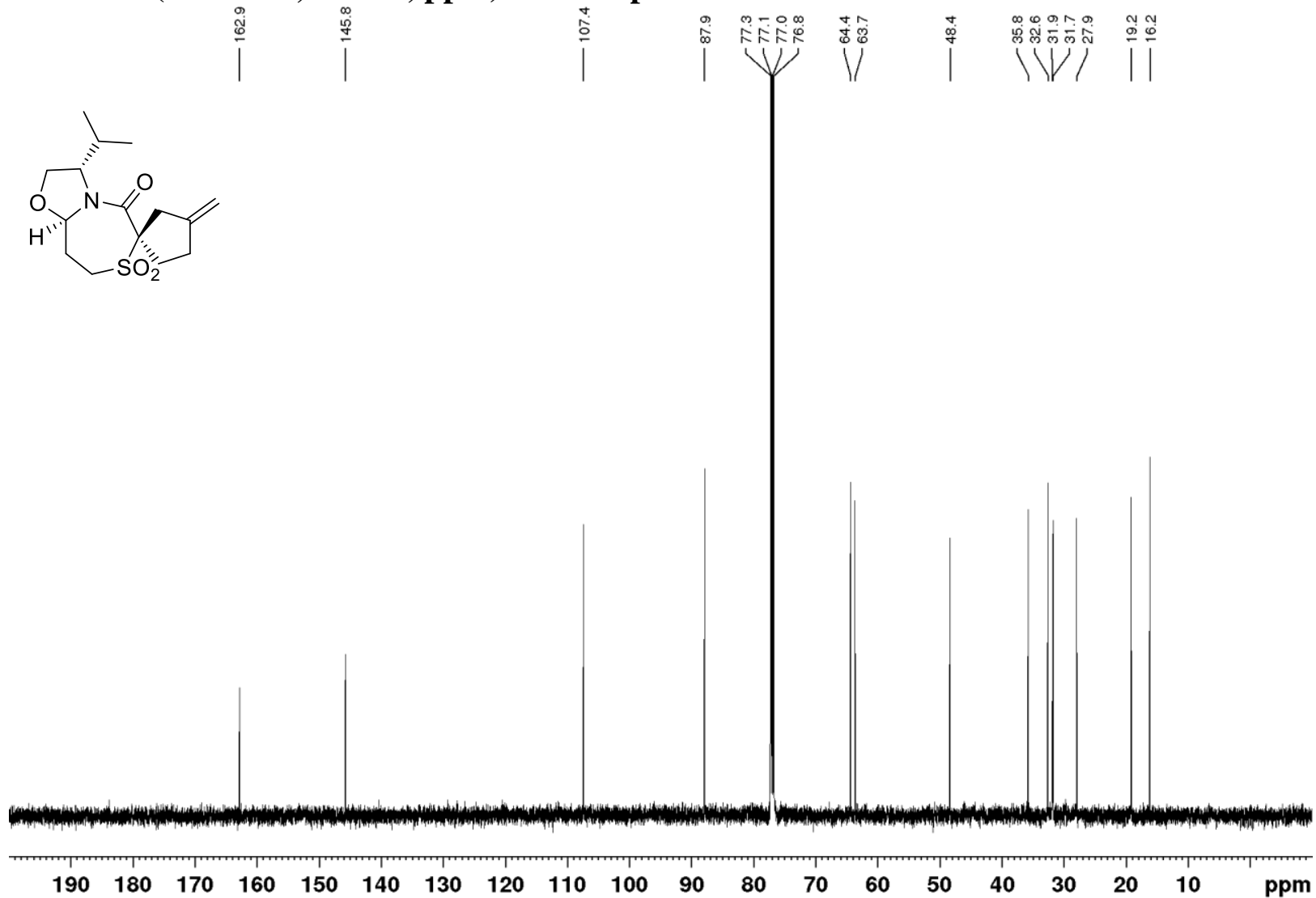

S-55 
$\operatorname{COSY}\left(500 \mathrm{MHz}, \mathrm{CDCl}_{3}, \mathrm{ppm}\right)$ for Compound 13d

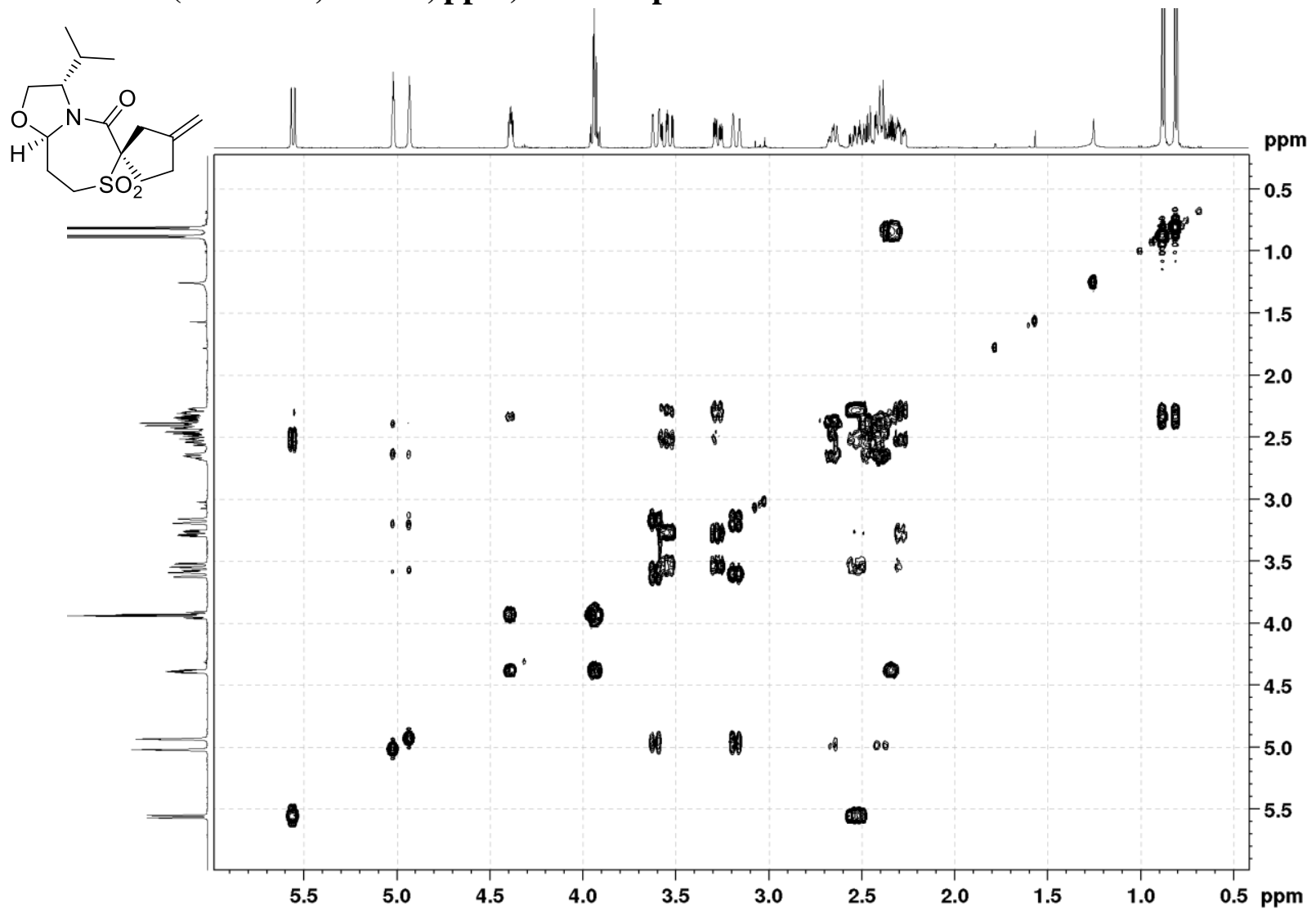

HSQC (500 MHz, CDCl3, ppm) for Compound 13d

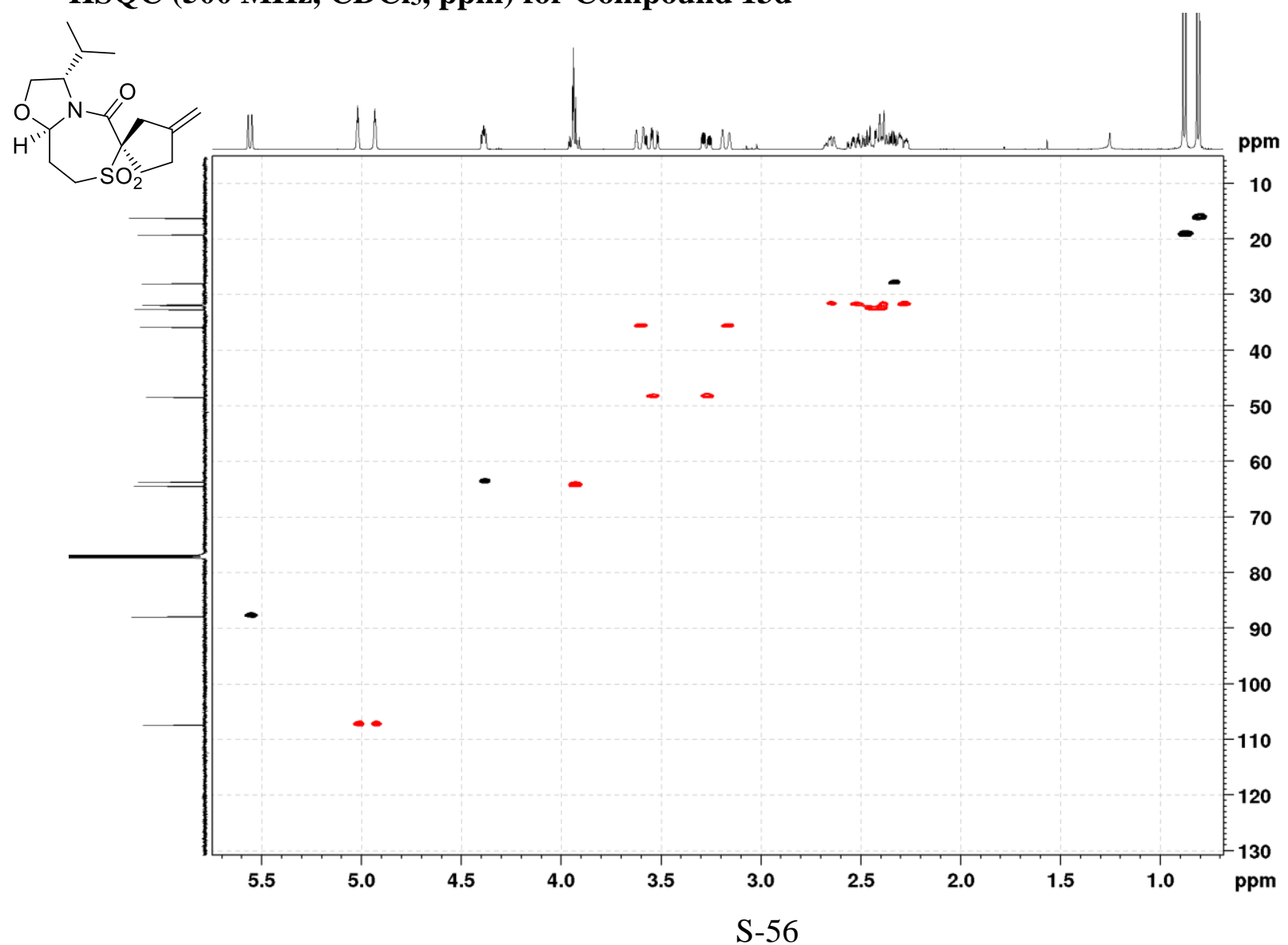


HMBC (500 MHz, $\mathrm{CDCl}_{3}$, ppm) for Compound 13d

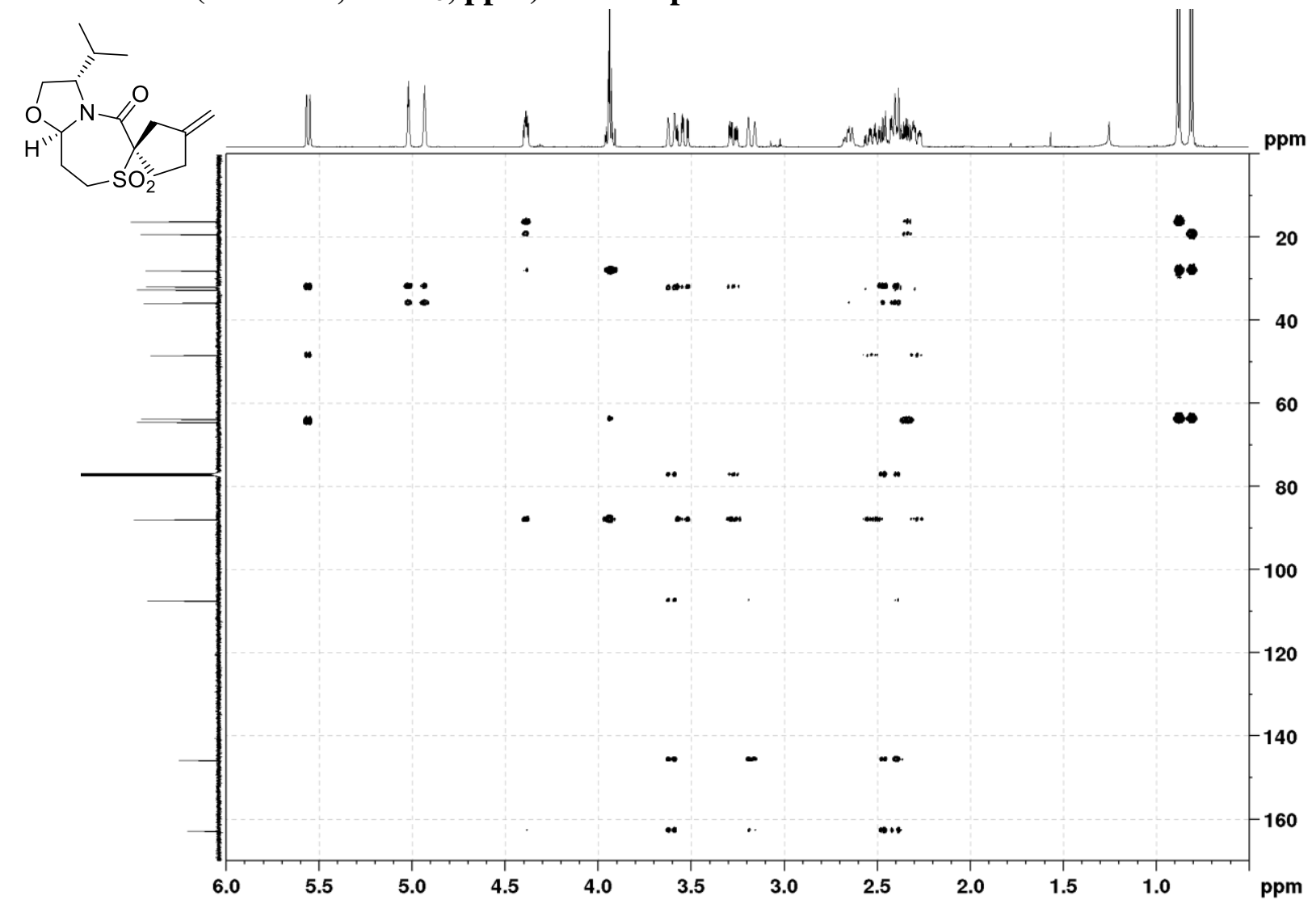

NOESY (500 MHz, CDCl3, ppm) for Compound 13d

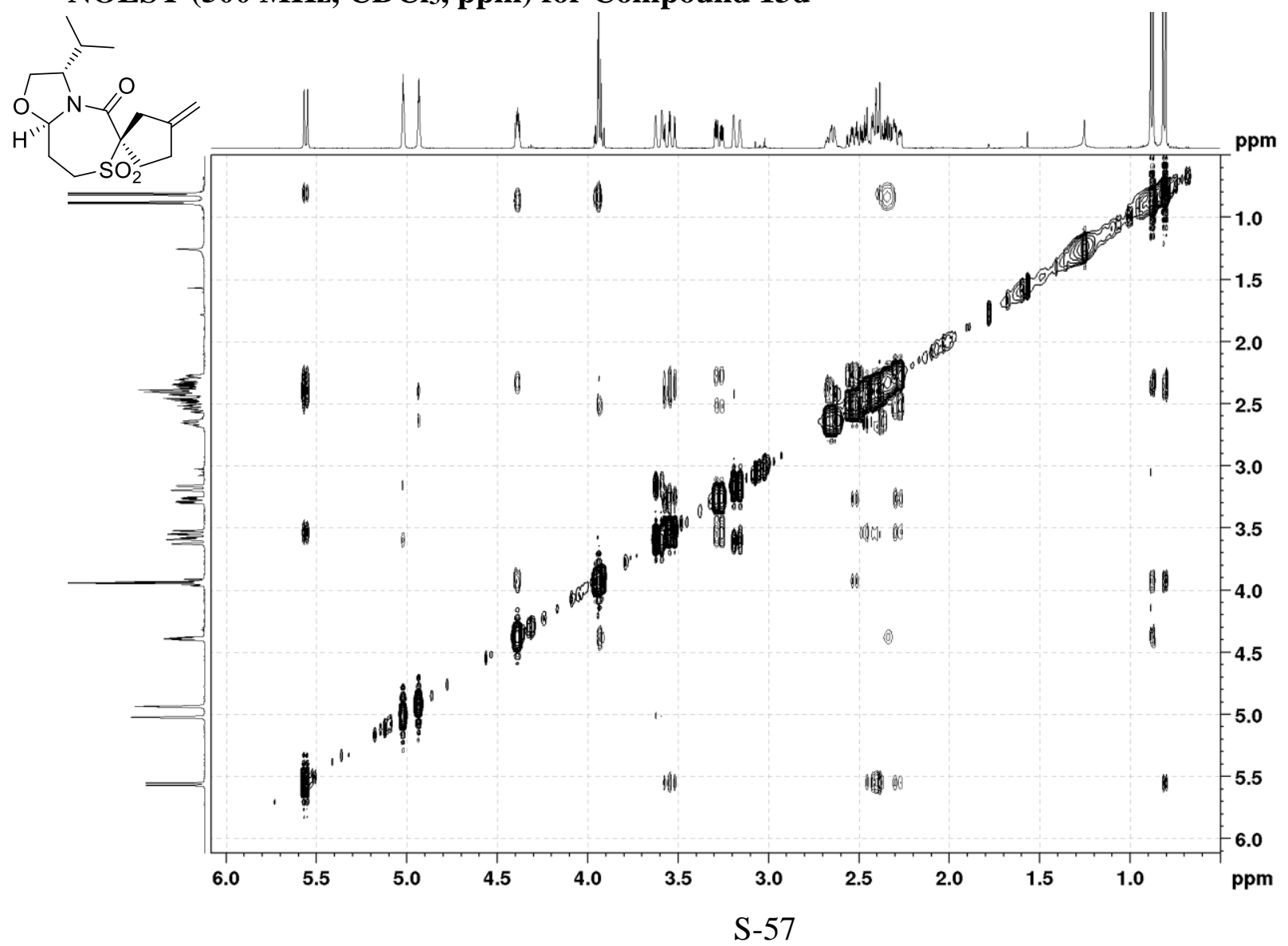


${ }^{1} \mathrm{H}$ NMR (500 MHz, $\left.\mathrm{CDCl}_{3}, \mathrm{ppm}\right)$ for Compound 13e

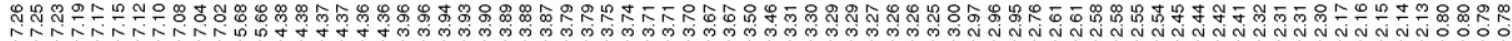

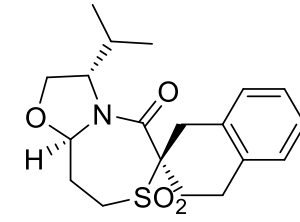

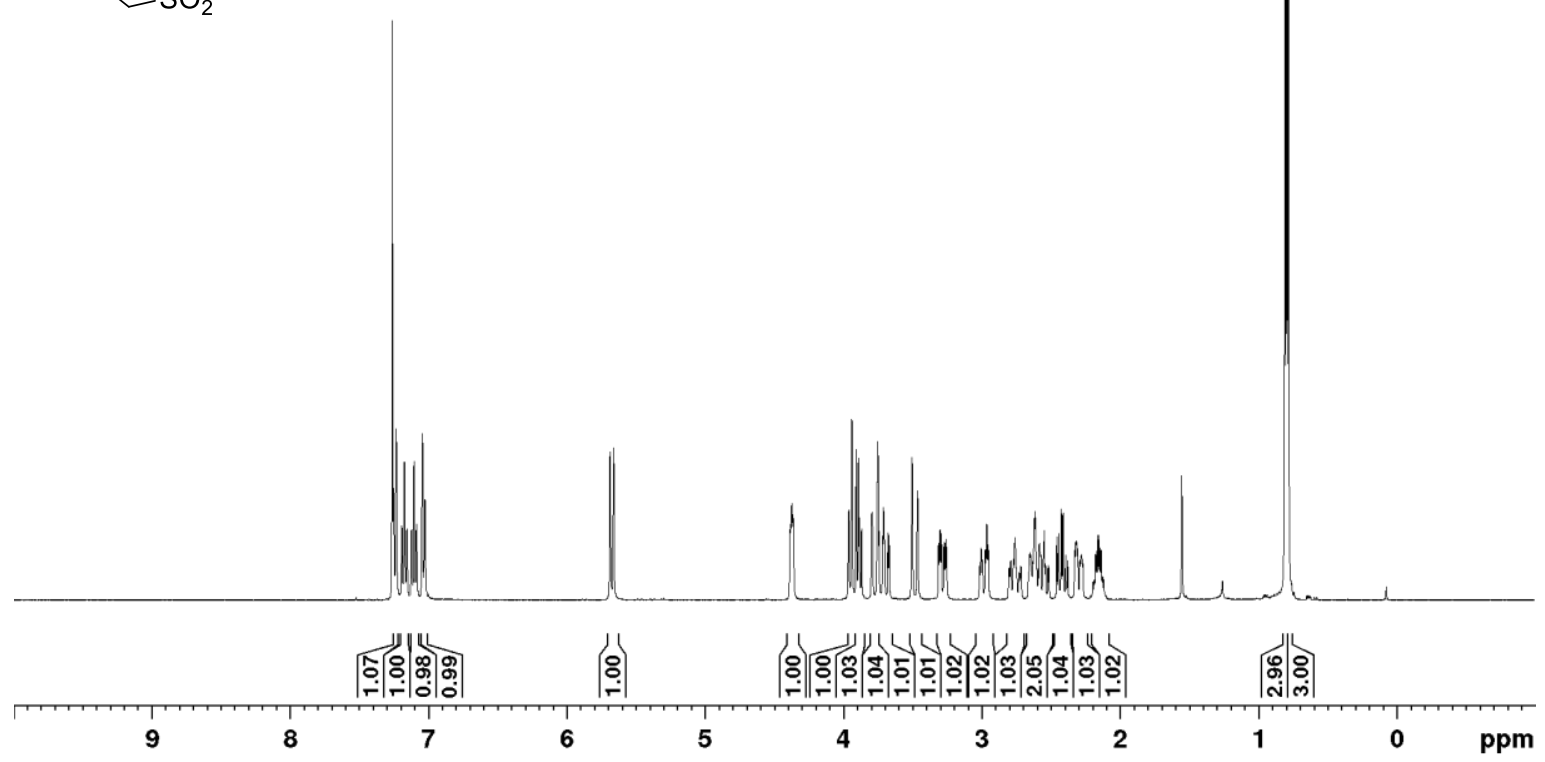

${ }^{13} \mathrm{C}$ NMR (500 MHz, $\mathrm{CDCl}_{3}$, ppm) for Compound 13e
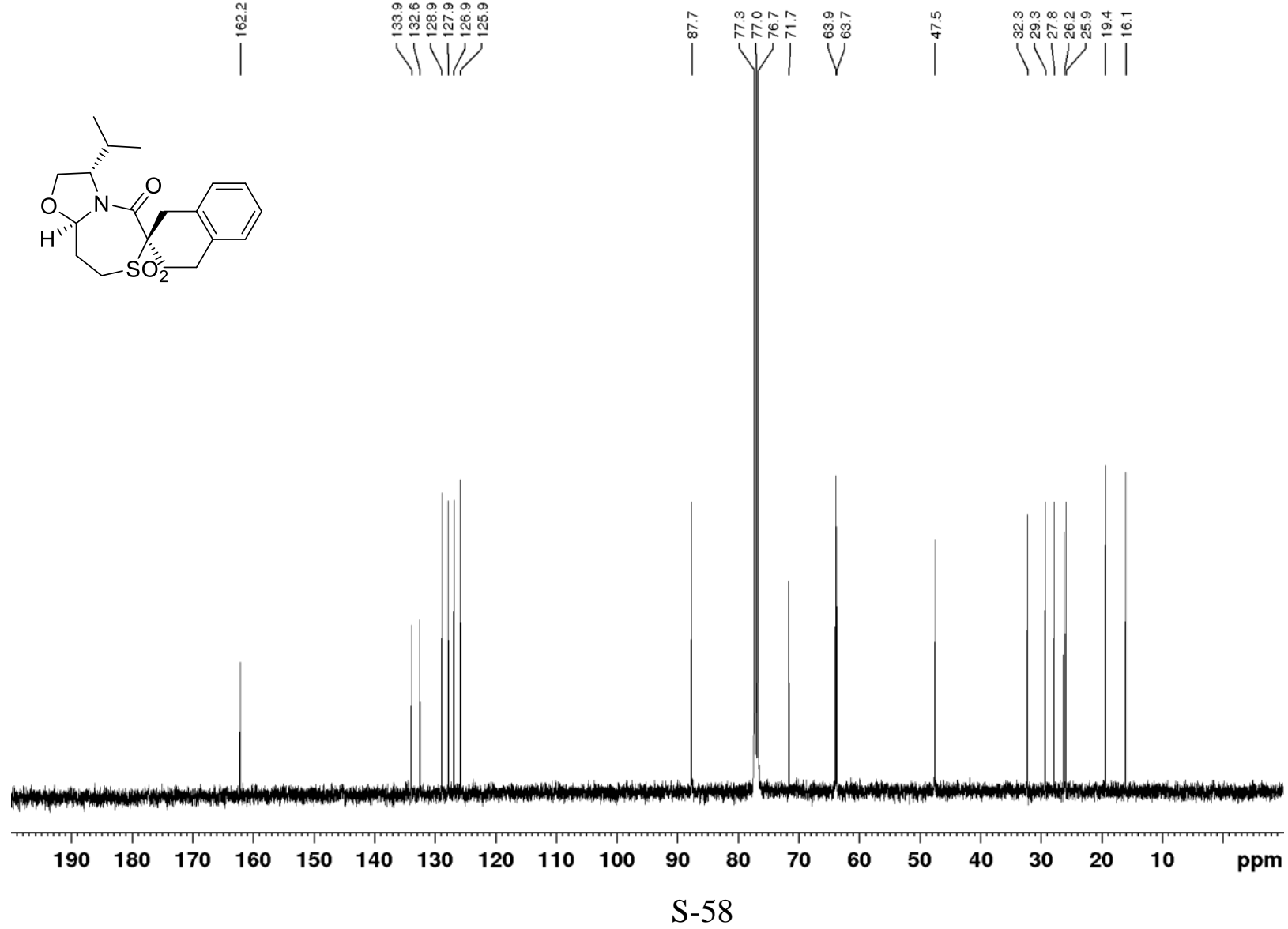
COSY (500 MHz, $\left.\mathrm{CDCl}_{3}, \mathrm{ppm}\right)$ for Compound $13 \mathrm{e}$

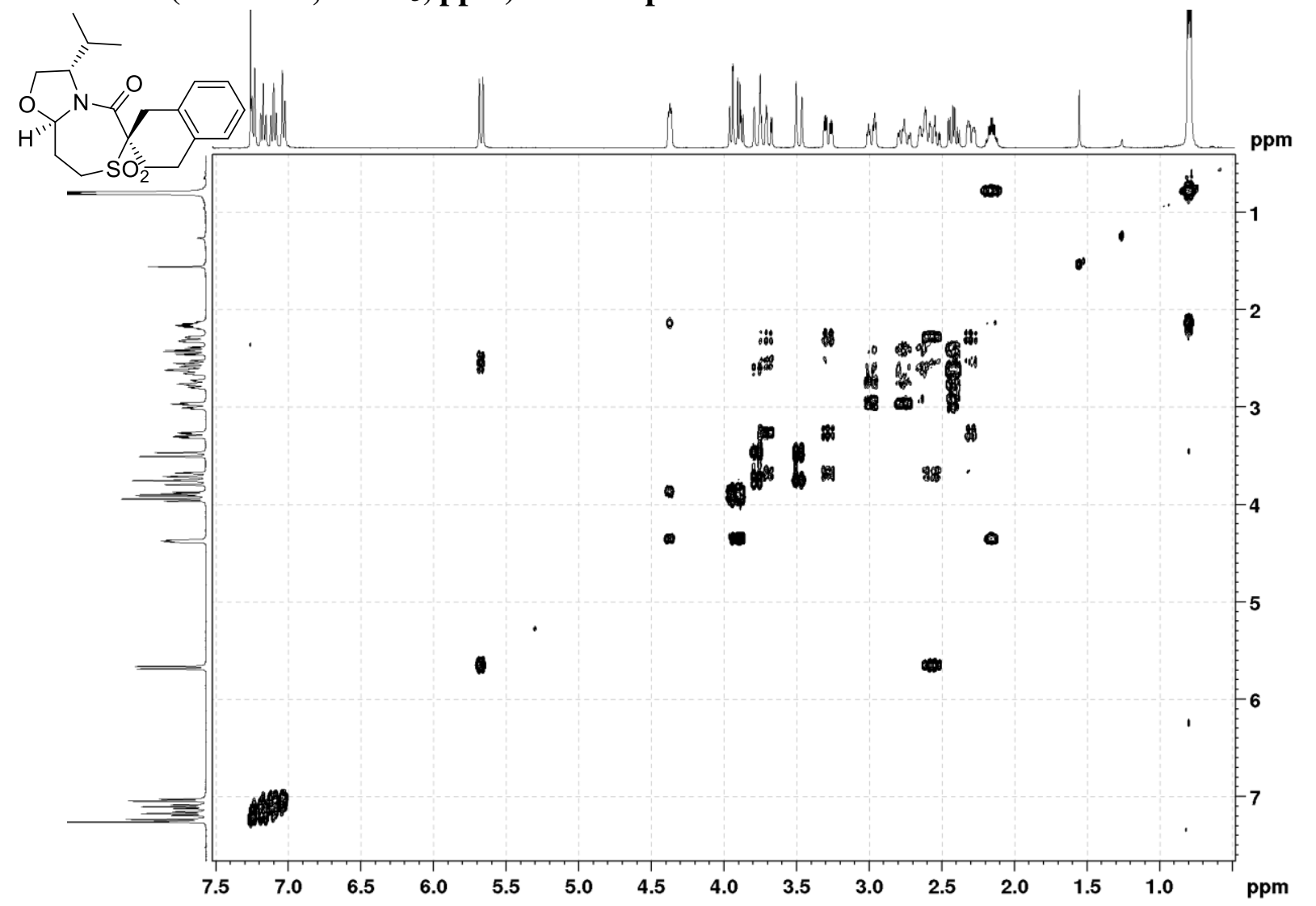

HSQC (500 MHz, CDCl3, ppm) for Compound 13e

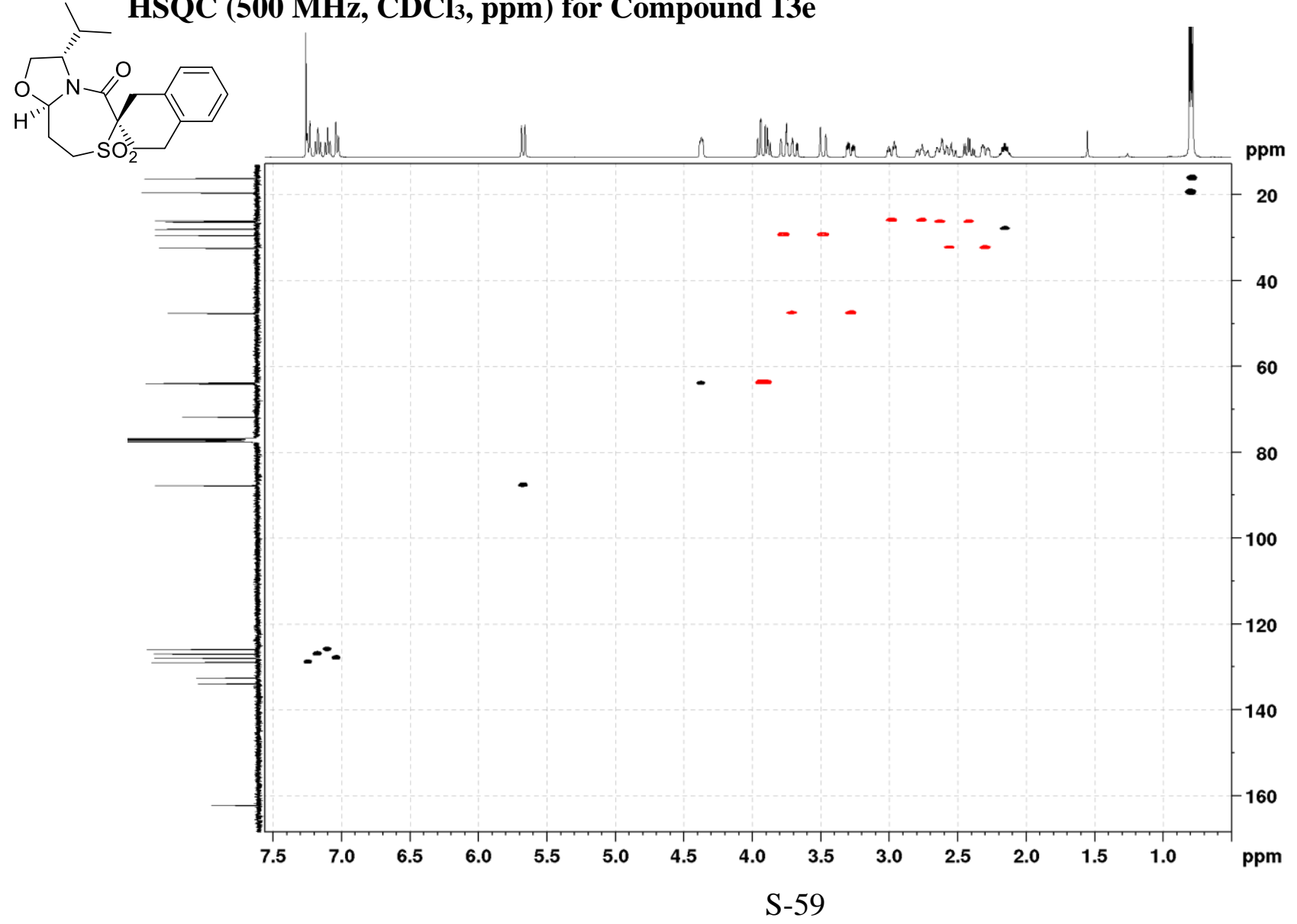


HMBC (500 MHz, $\mathrm{CDCl}_{3}$, ppm) for Compound 13e

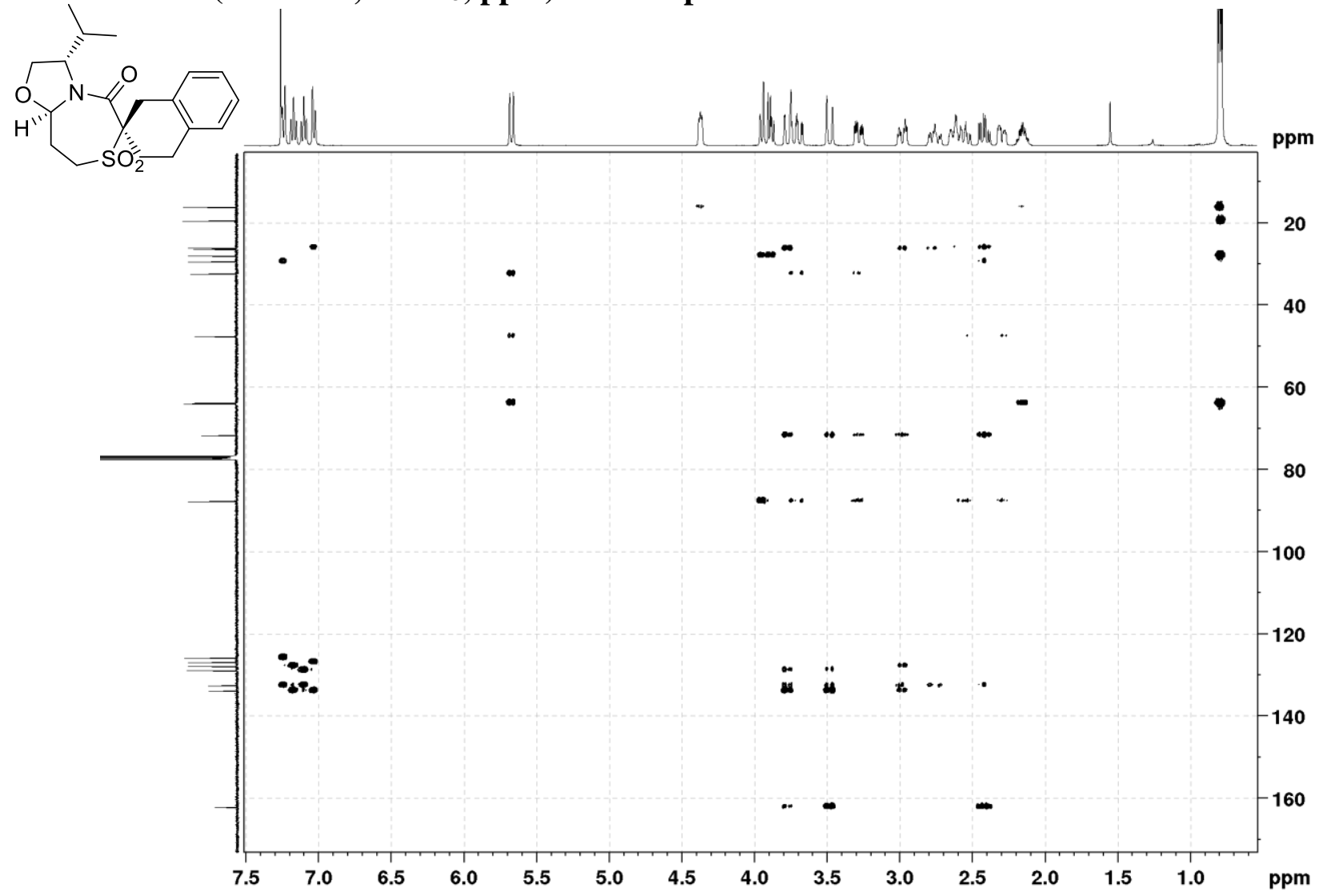

NOESY (500 MHz, $\mathrm{CDCl}_{3}$, ppm) for Compound 13e

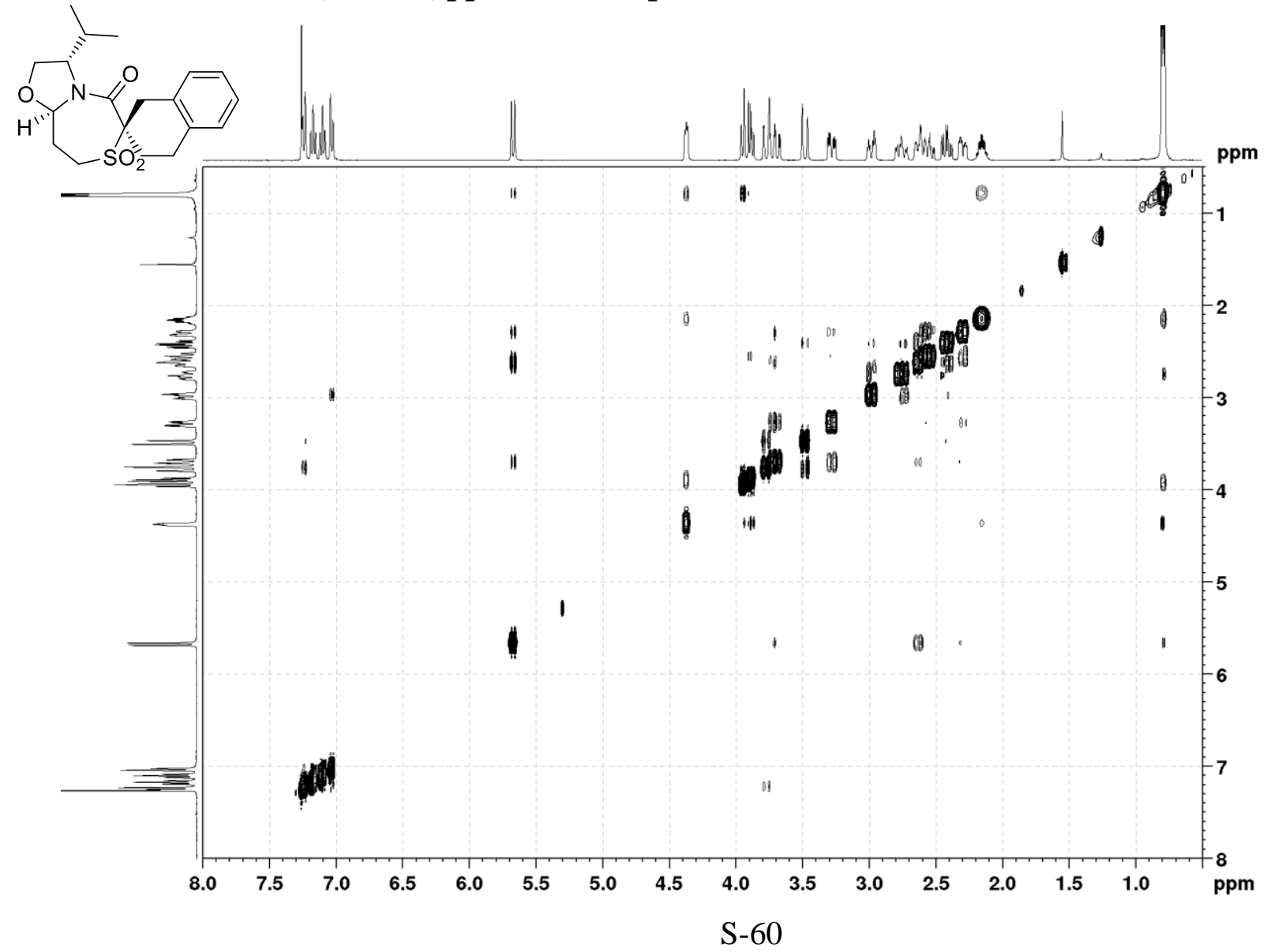


${ }^{1} \mathrm{H}$ NMR (500 MHz, $\mathrm{CDCl}_{3}$, ppm) for Compound 13f:

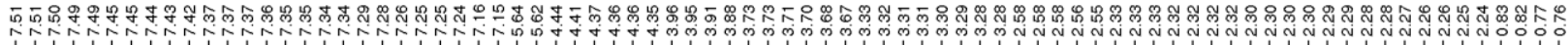

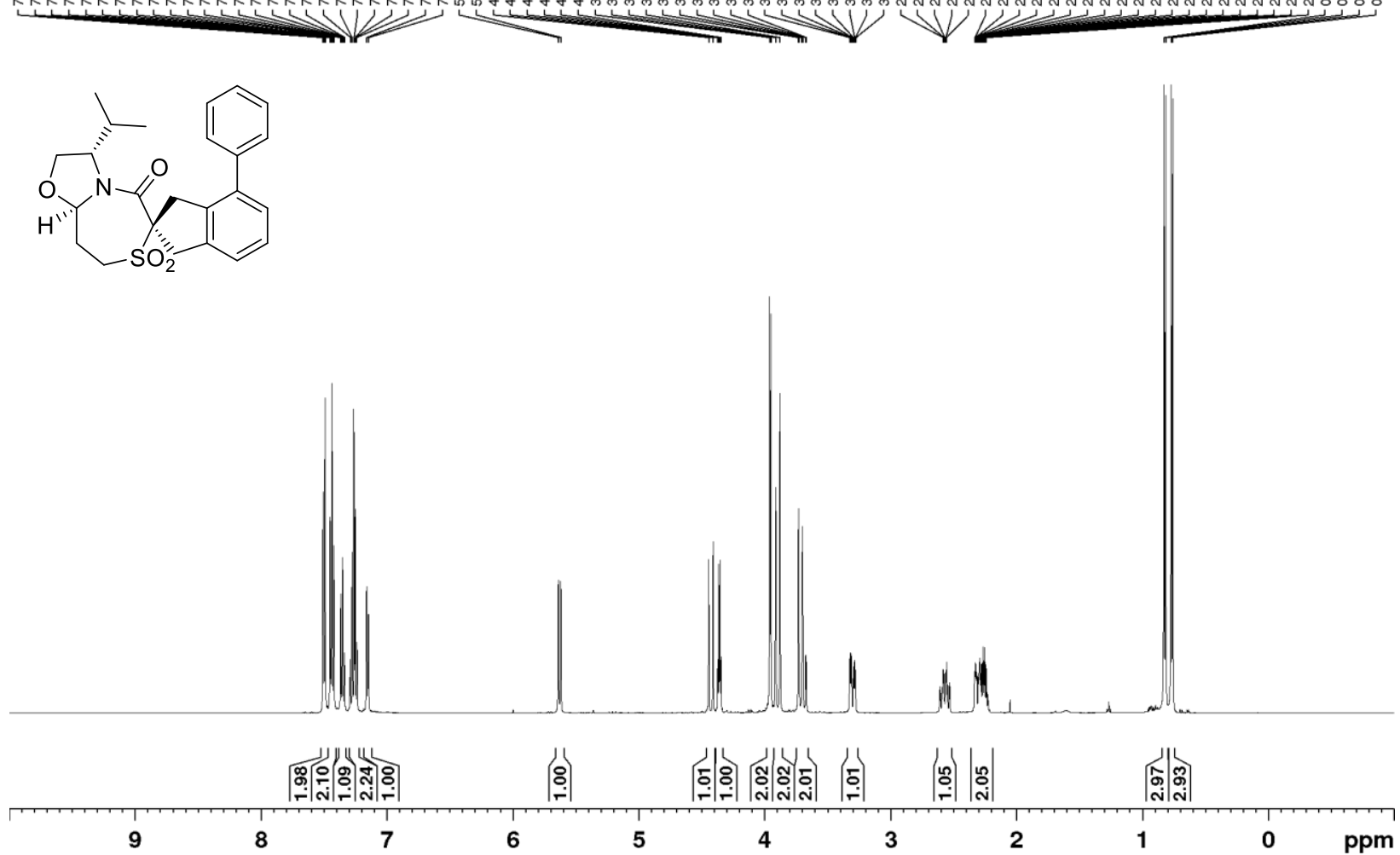

${ }^{13} \mathrm{C}$ NMR (126 MHz, $\mathrm{CDCl}_{3}$, ppm) for Compound 13f:

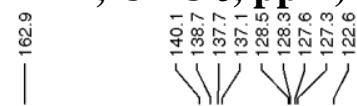

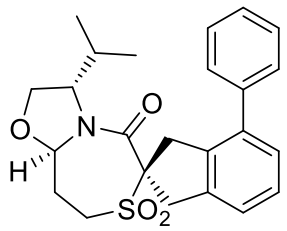
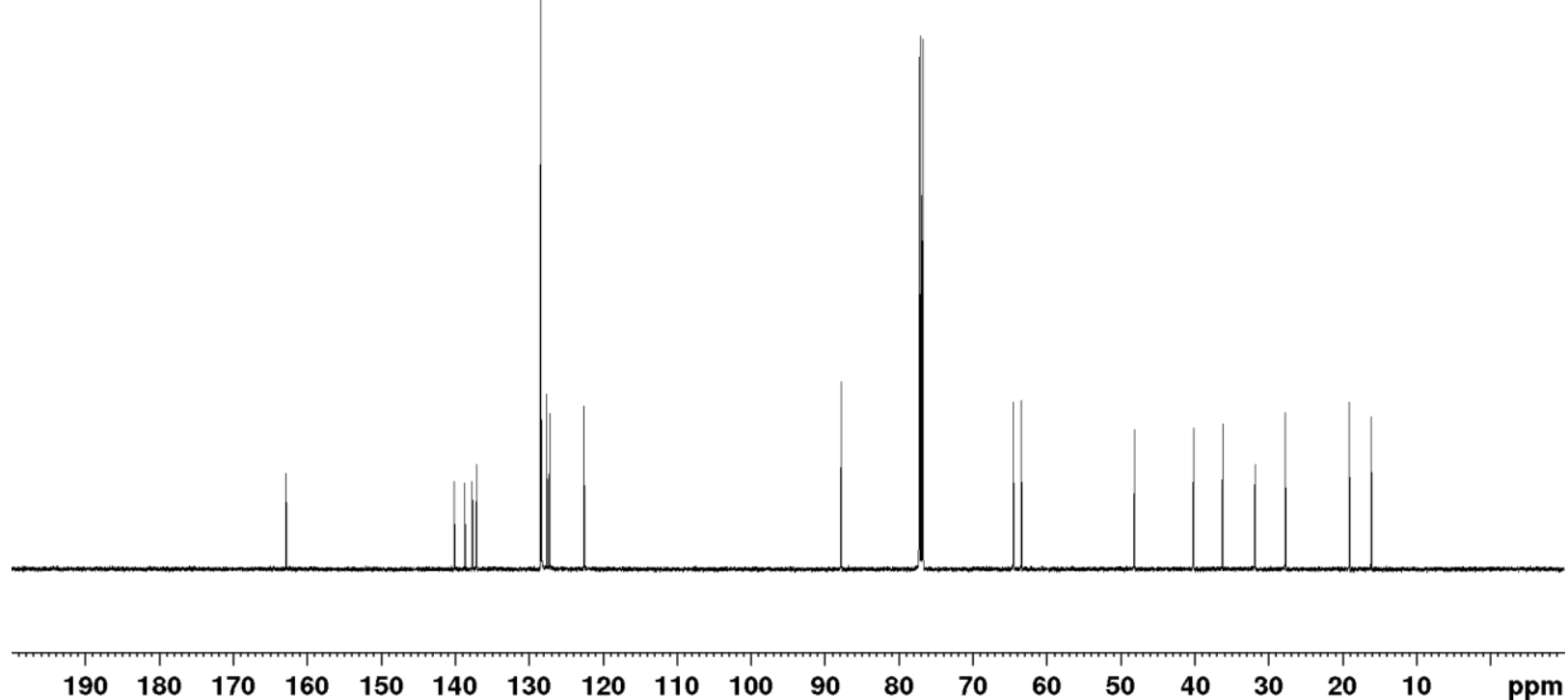

$\operatorname{COSY}\left(500 \mathrm{MHz}, \mathrm{CDCl}_{3}, \mathrm{ppm}\right)$ for Compound 13f: 


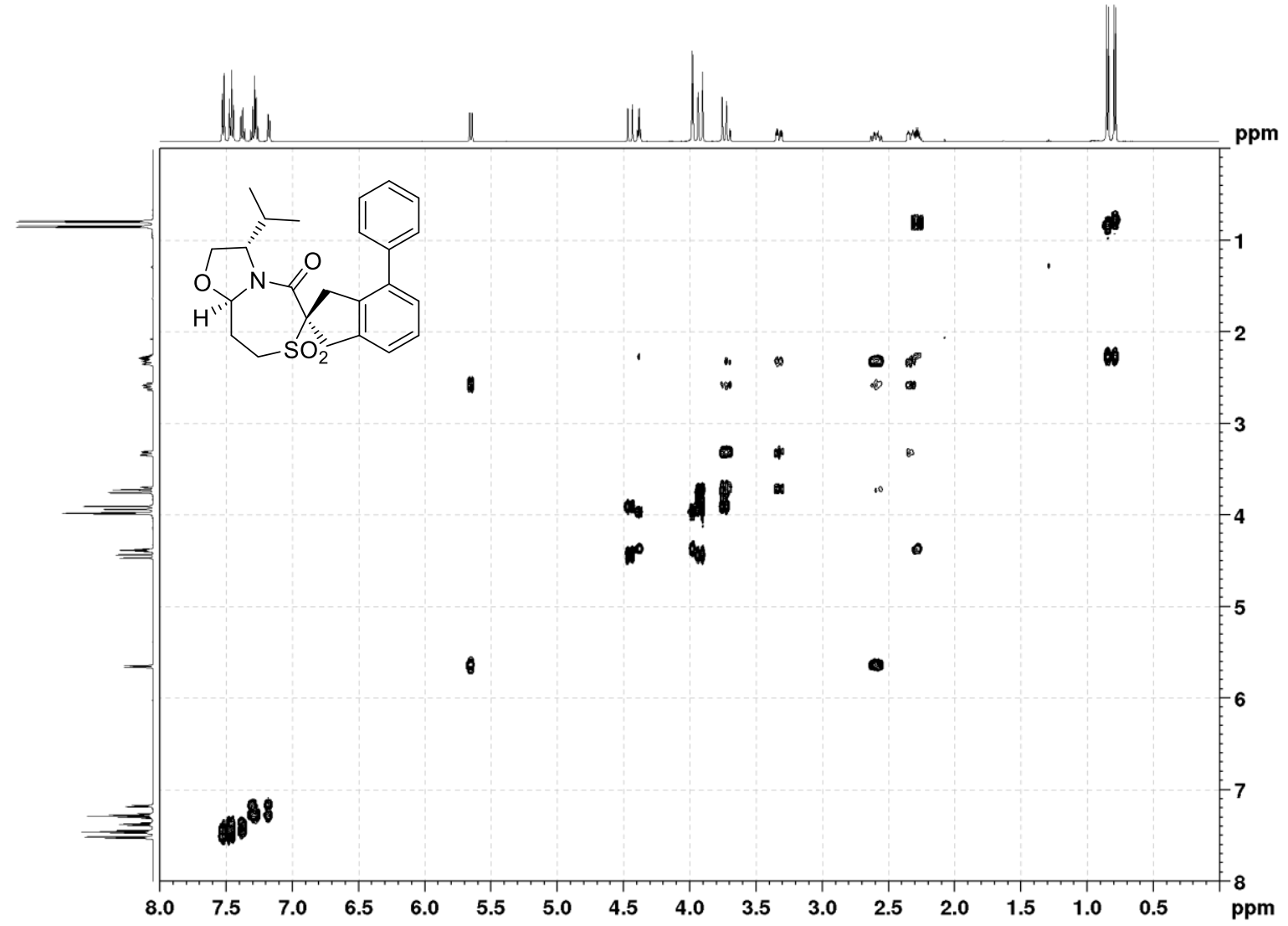

HSQC (500 MHz, CDCl3, ppm) for Compound 13f:

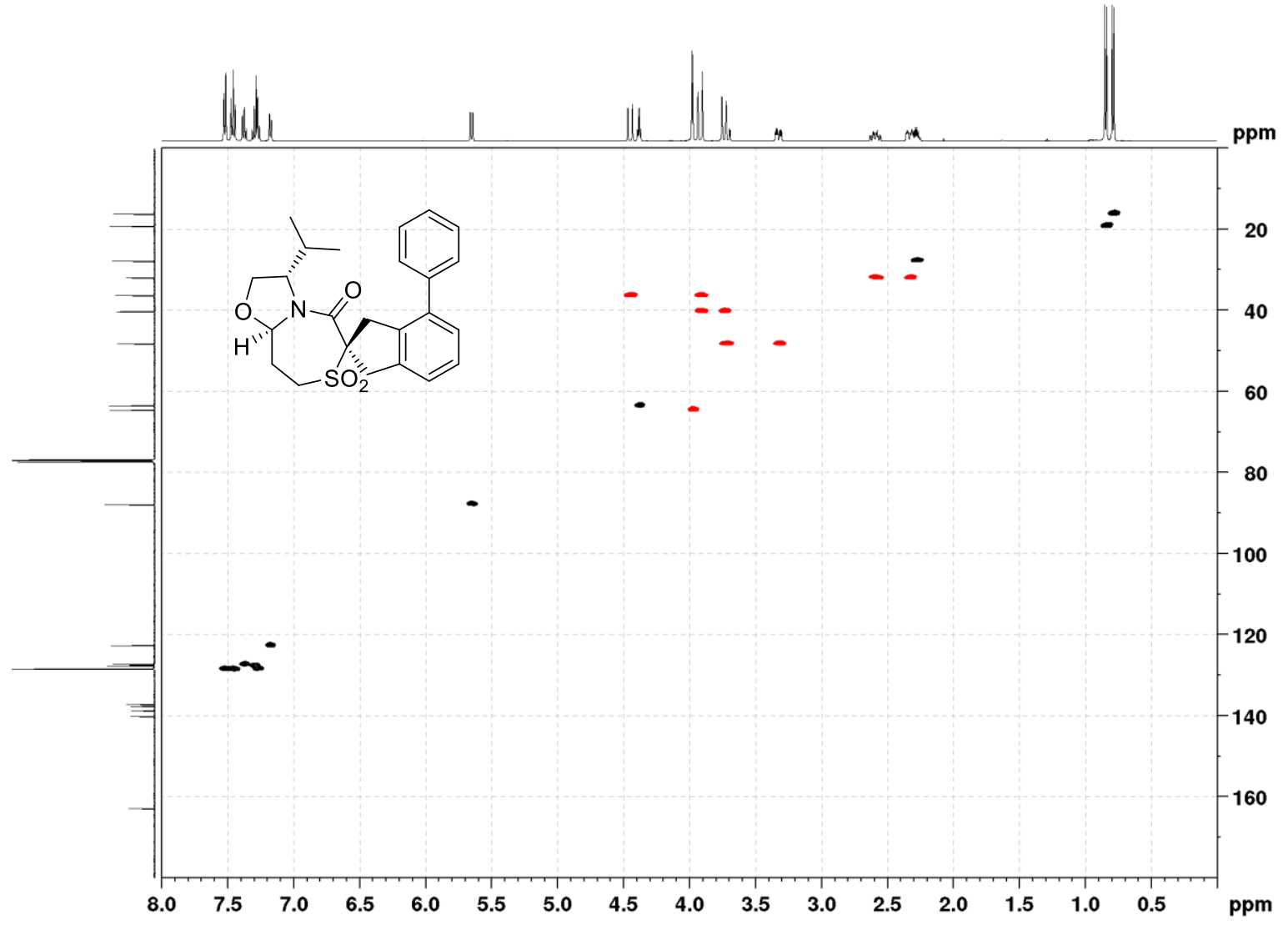


HMBC (500 MHz, $\mathrm{CDCl}_{3}$, ppm) for Compound 13f:

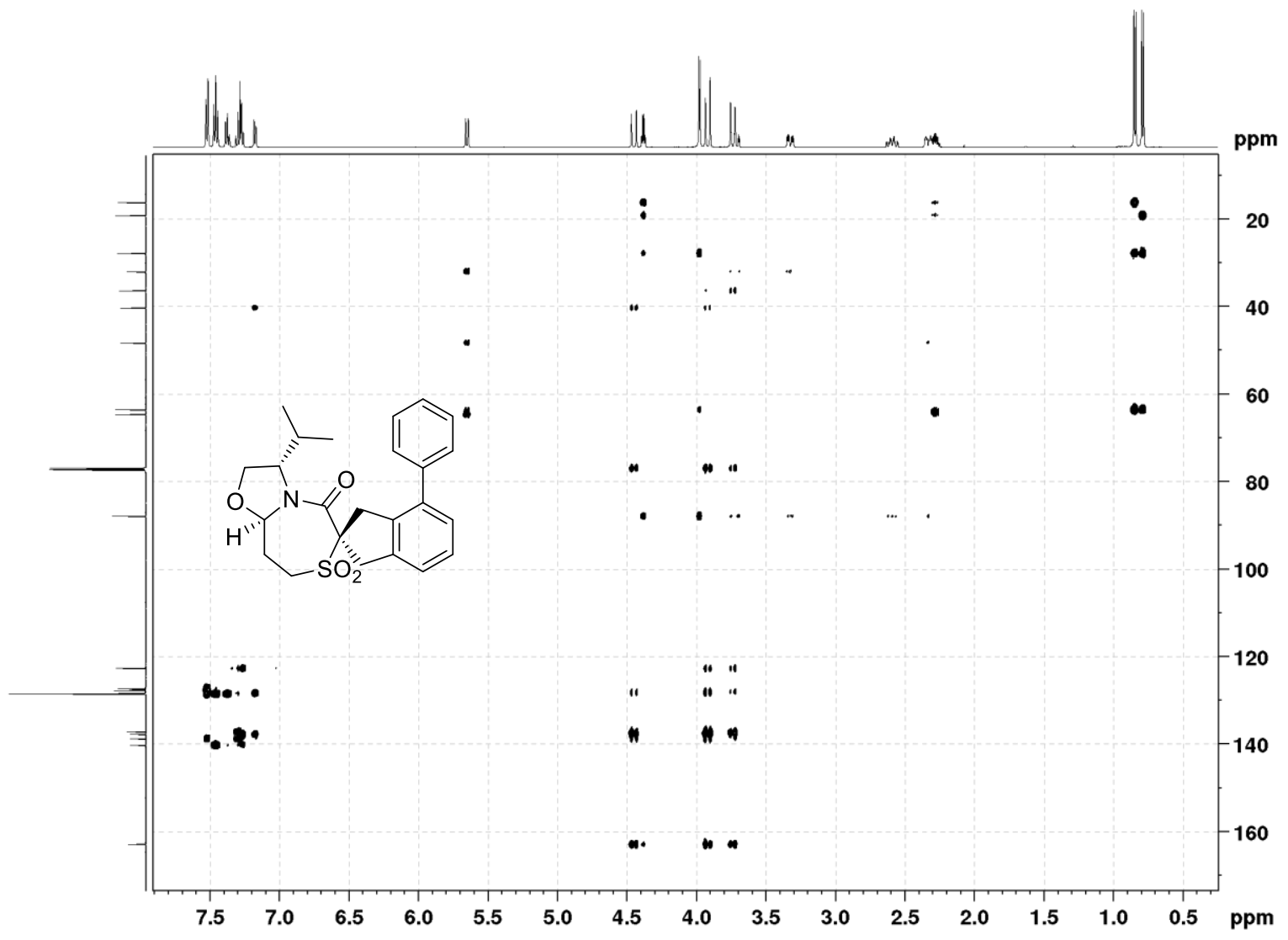

NOESY (500 MHz, CDCl3, ppm) for Compound 13f:

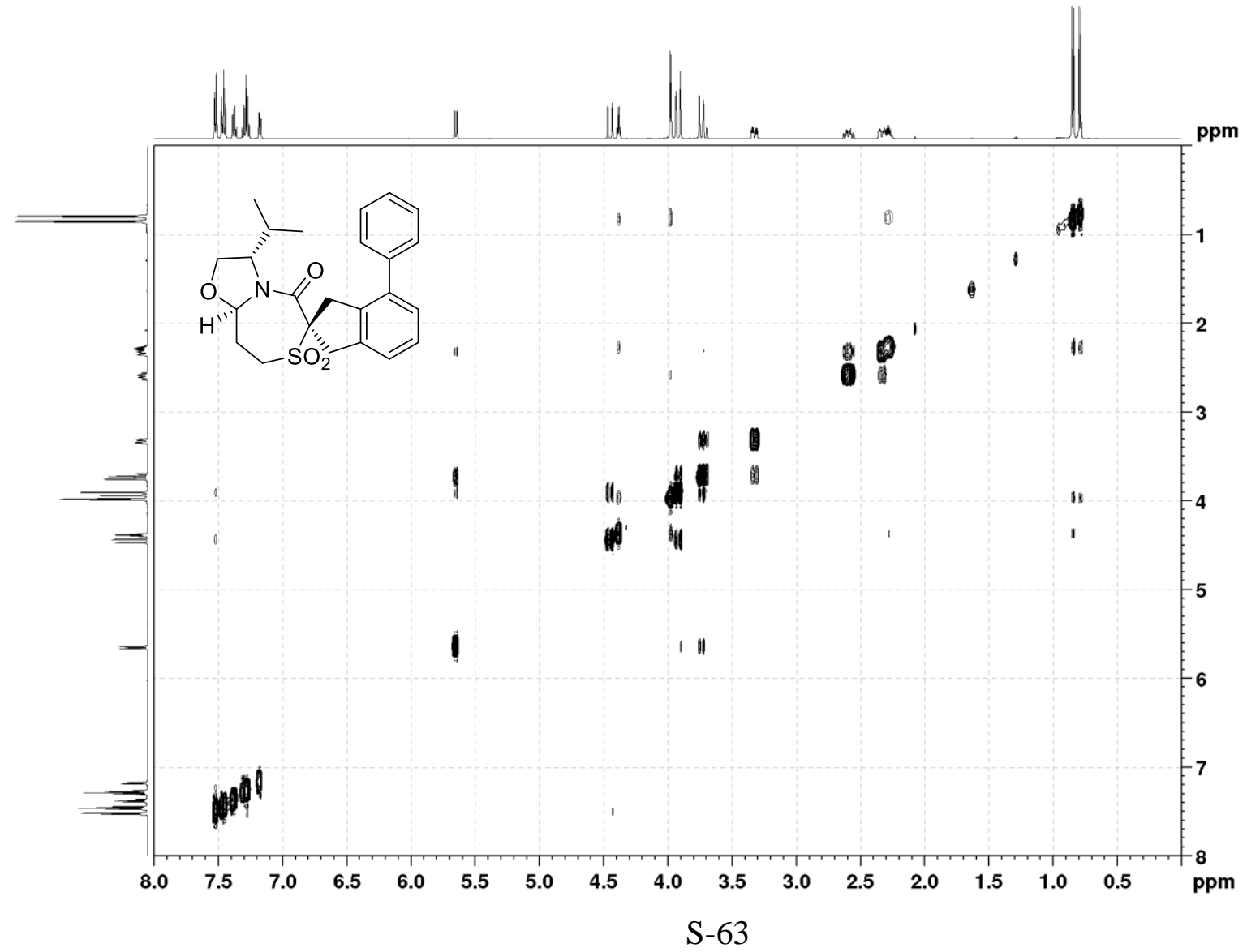


${ }^{1} \mathrm{H}$ NMR (500 MHz, $\left.\mathrm{CDCl}_{3}, \mathrm{ppm}\right)$ for Compound $13 \mathrm{~g}$

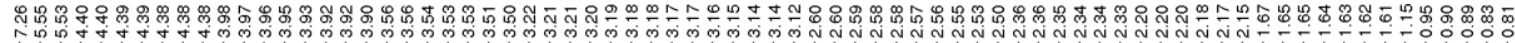
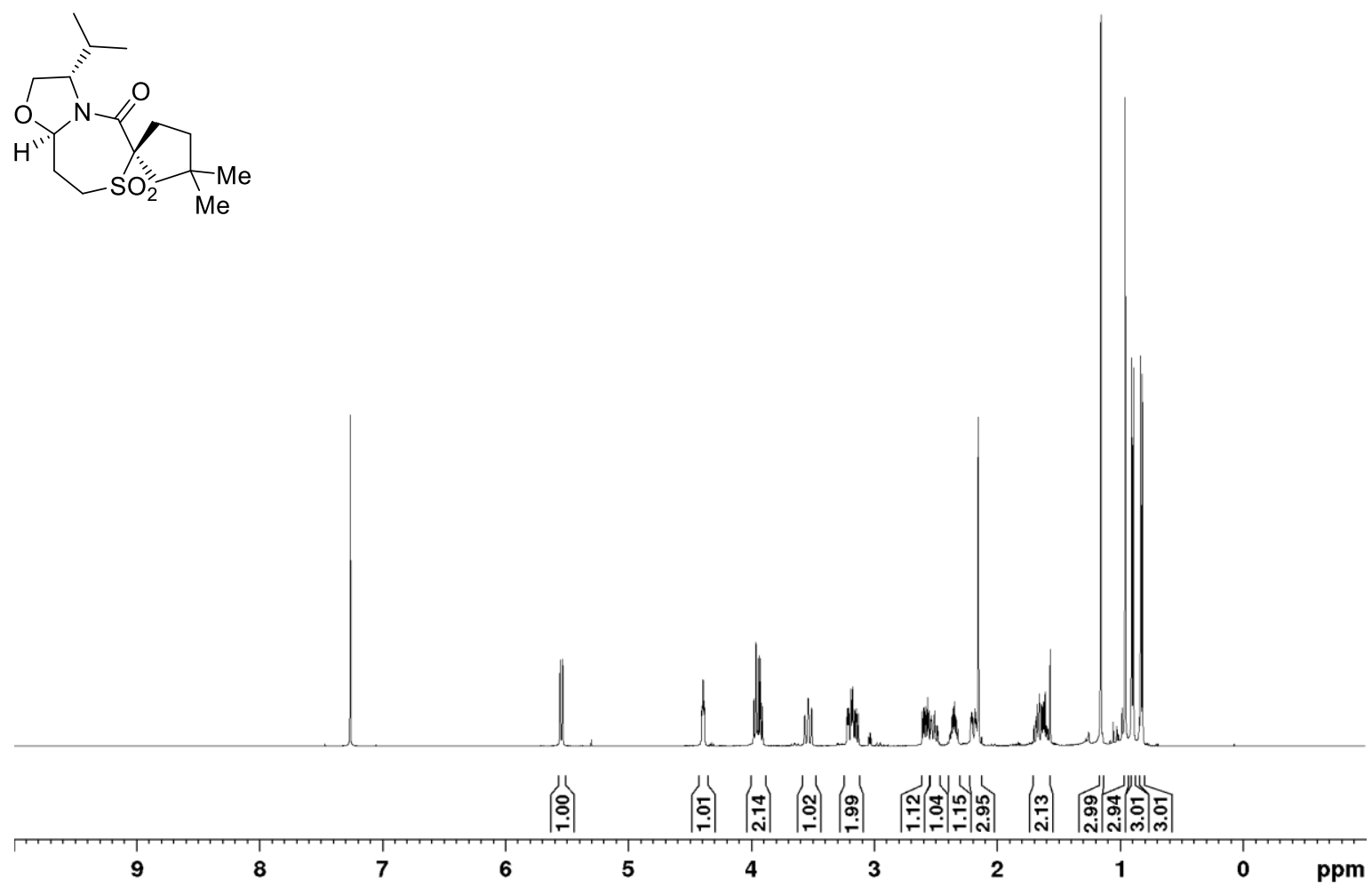

${ }^{13} \mathrm{C}$ NMR (126 MHz, CDCl3, ppm) for Compound 13g
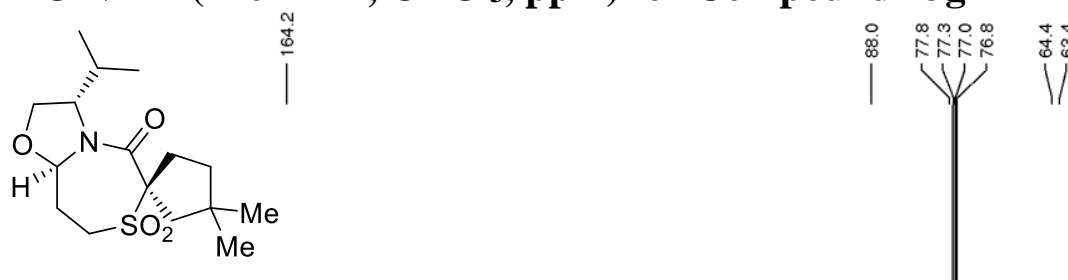

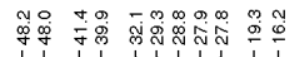

V11

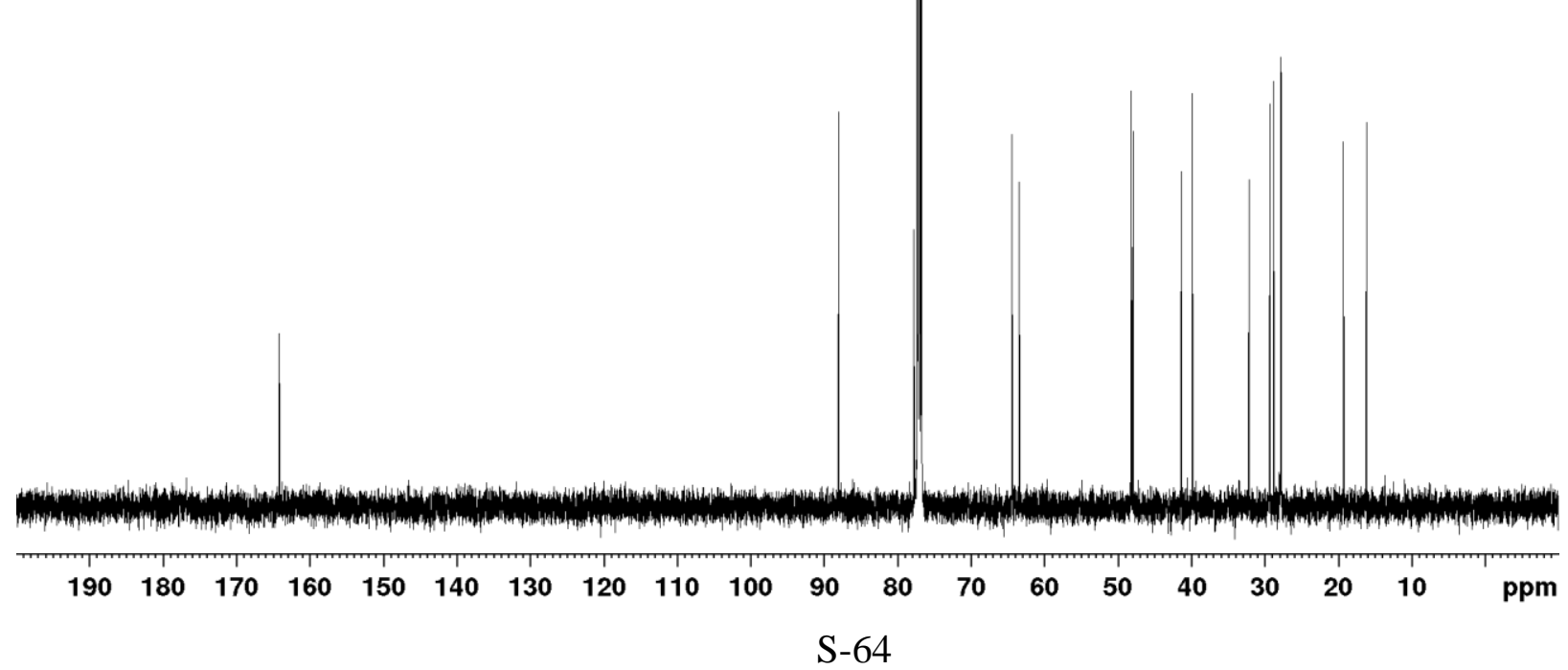


HSQC (500 MHz, $\mathrm{CDCl}_{3}, \mathrm{ppm}$ ) for Compound 13g

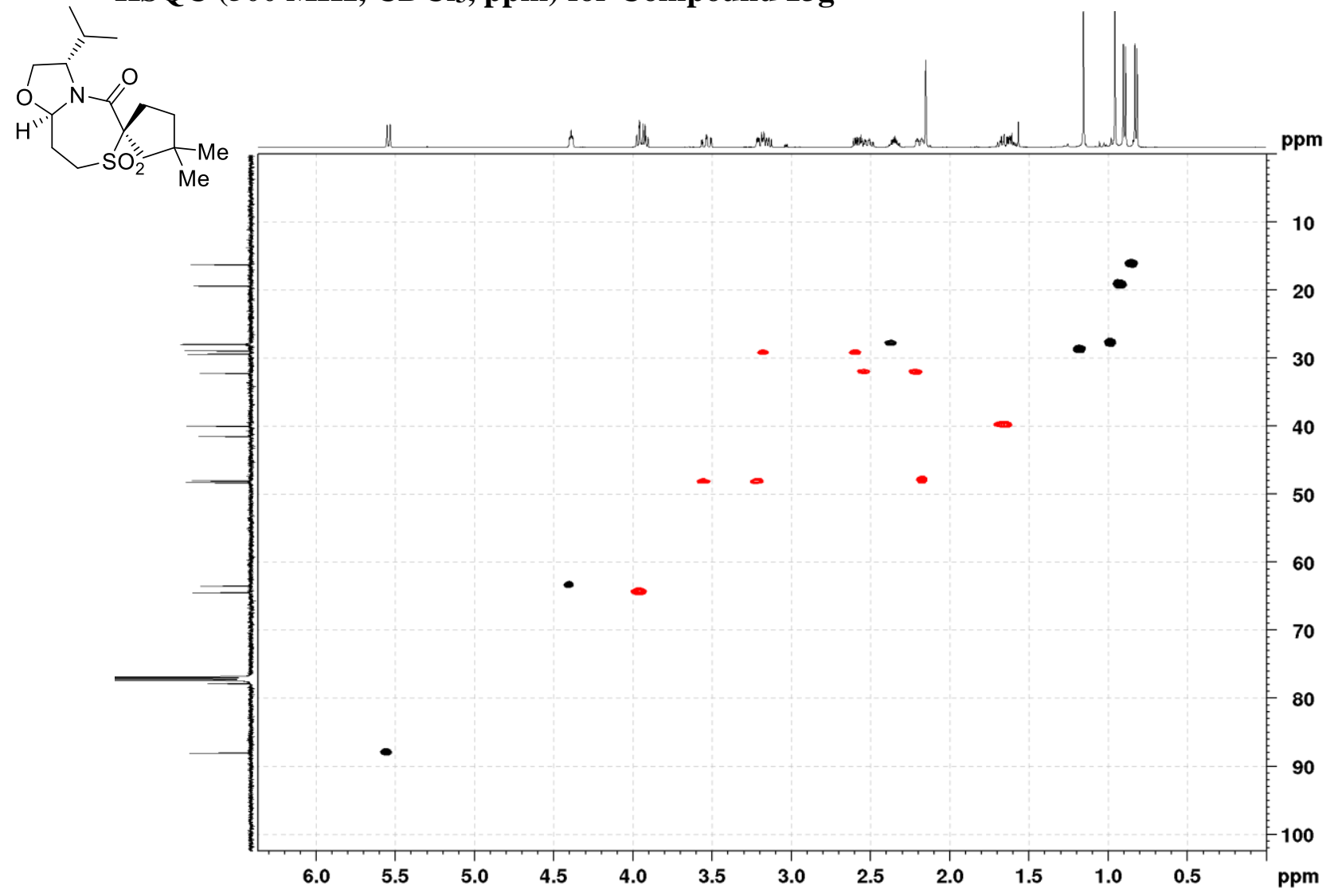

NOESY ( $500 \mathrm{MHz}, \mathrm{CDCl}_{3}$, ppm) for Compound 13g

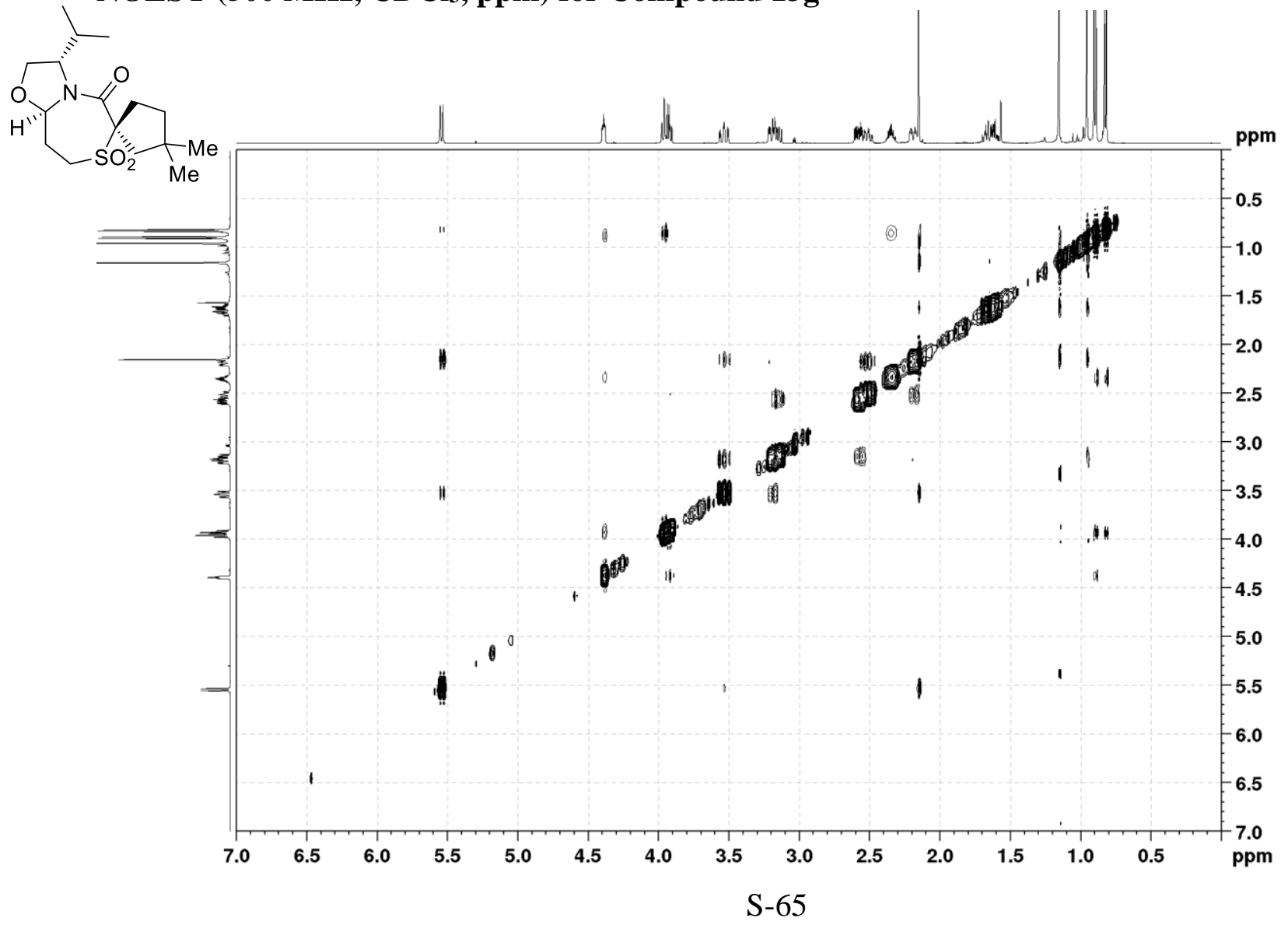


${ }^{1} \mathrm{H}$ NMR (500 MHz, $\left.\mathrm{CDCl}_{3}, \mathrm{ppm}\right)$ for Compound $(S, R, R)-15$

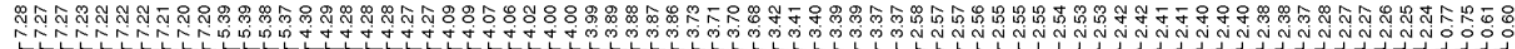<smiles></smiles>

$\mathrm{H}$

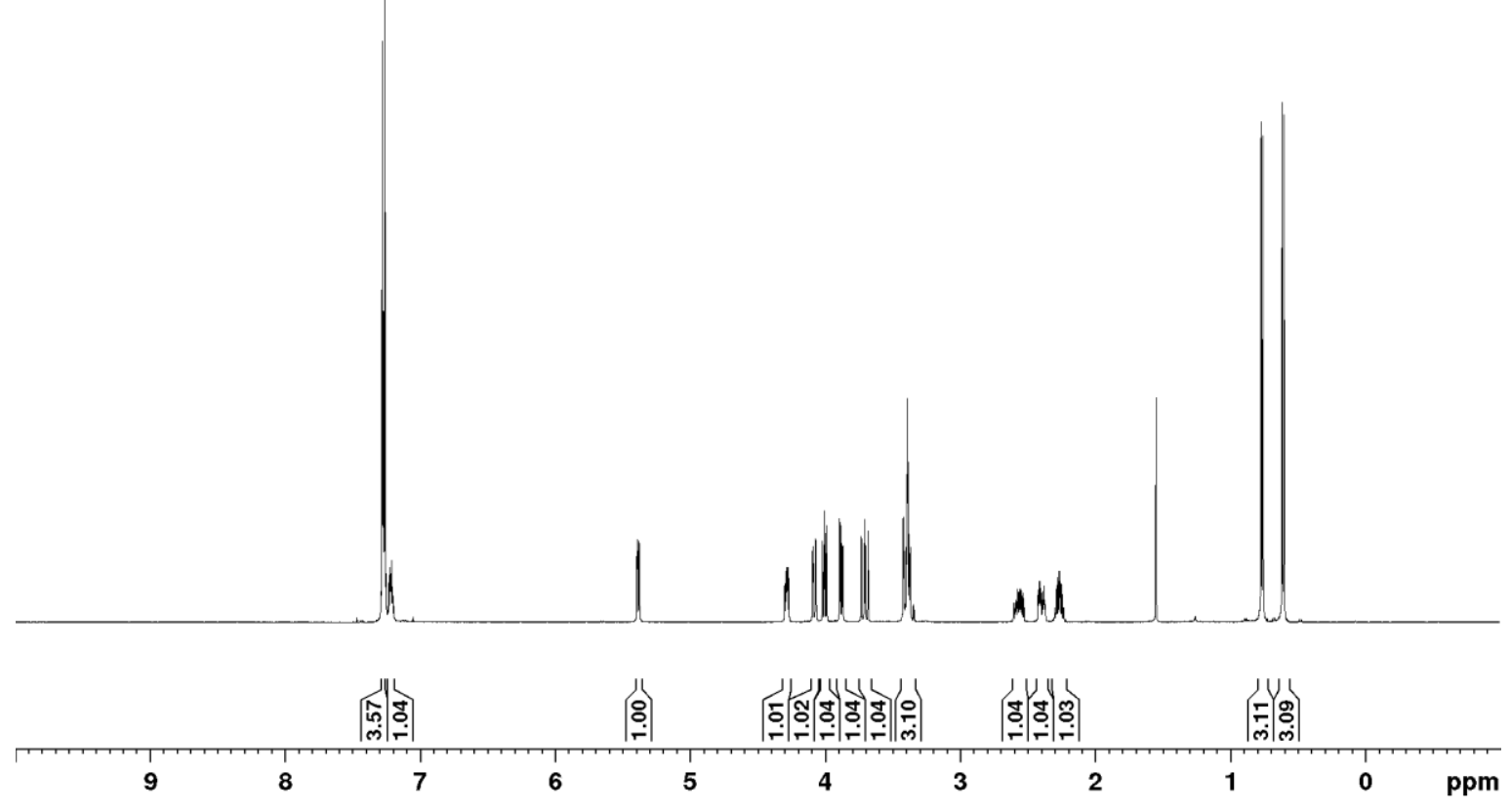

${ }^{13} \mathrm{C}$ NMR (126 MHz, $\left.\mathrm{CDCl}_{3}, \mathrm{ppm}\right)$ for Compound $(S, R, R)-15$

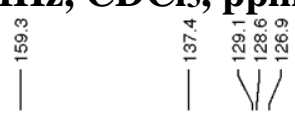

||$^{\infty}||^{\infty}$<smiles>CC(C)[C@H]1COC2CC[C@H](O)C(Cc3ccccc3)C2C1=O</smiles>

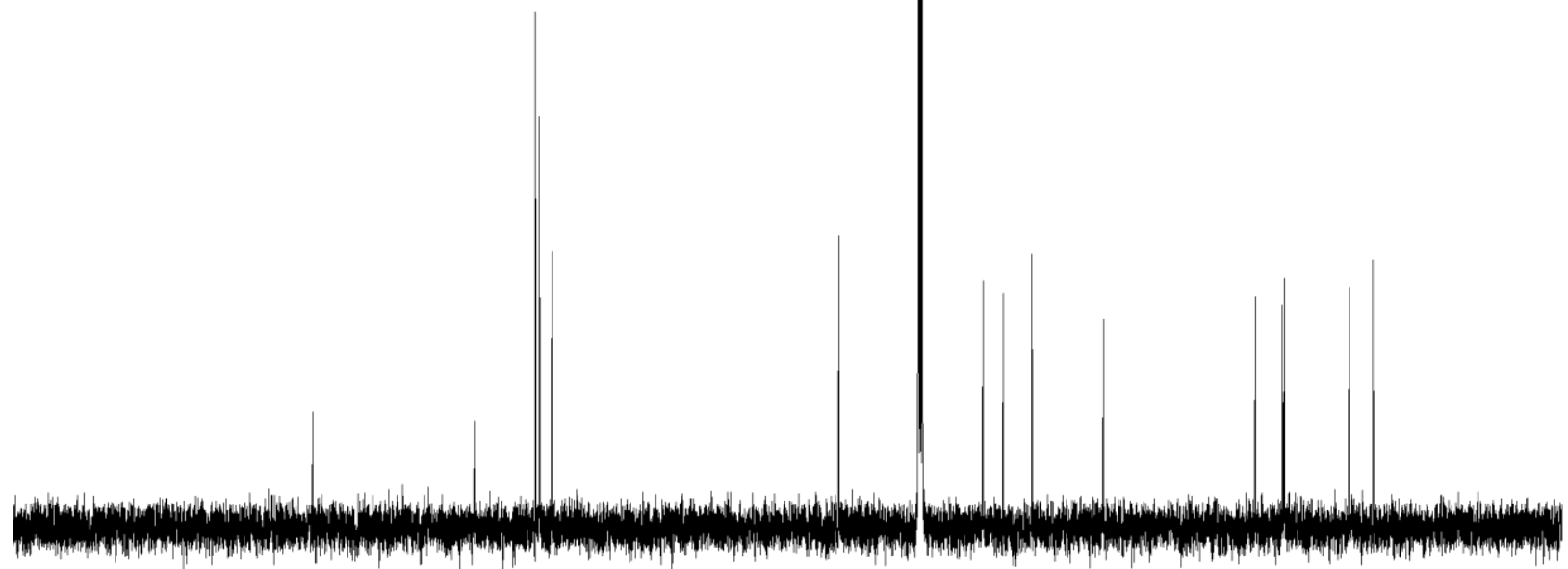

$\begin{array}{llllllllllllllllllll}190 & 180 & 170 & 160 & 150 & 140 & 130 & 120 & 110 & 100 & 90 & 80 & 70 & 60 & 50 & 40 & 30 & 20 & 10 & \mathrm{ppm}\end{array}$ 
COSY (500 MHz, $\left.\mathrm{CDCl}_{3}, \mathrm{ppm}\right)$ for Compound $(S, R, R)-15$

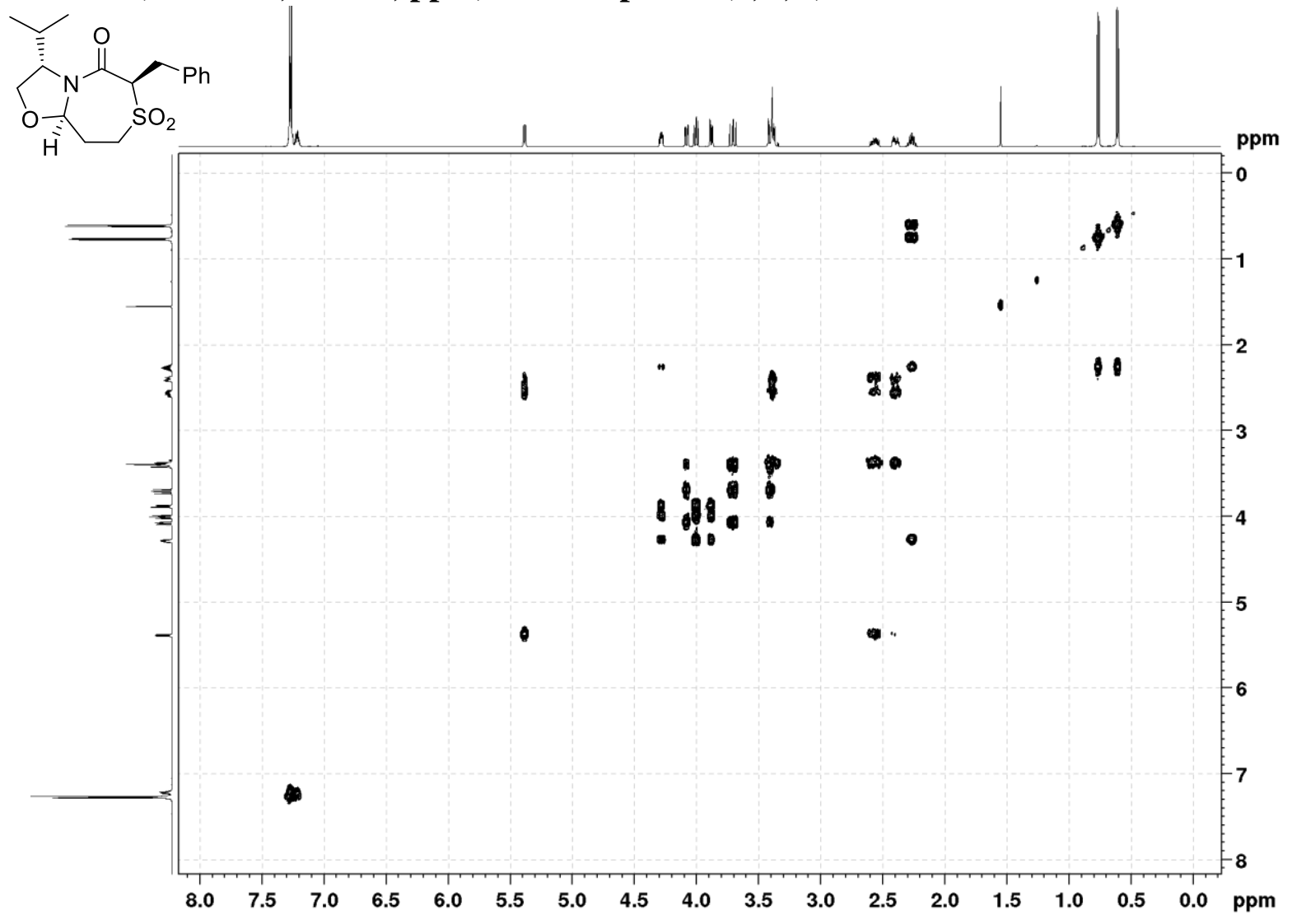

HSQC (500 MHz, CDCl3, ppm) for Compound $(S, R, R)-15$

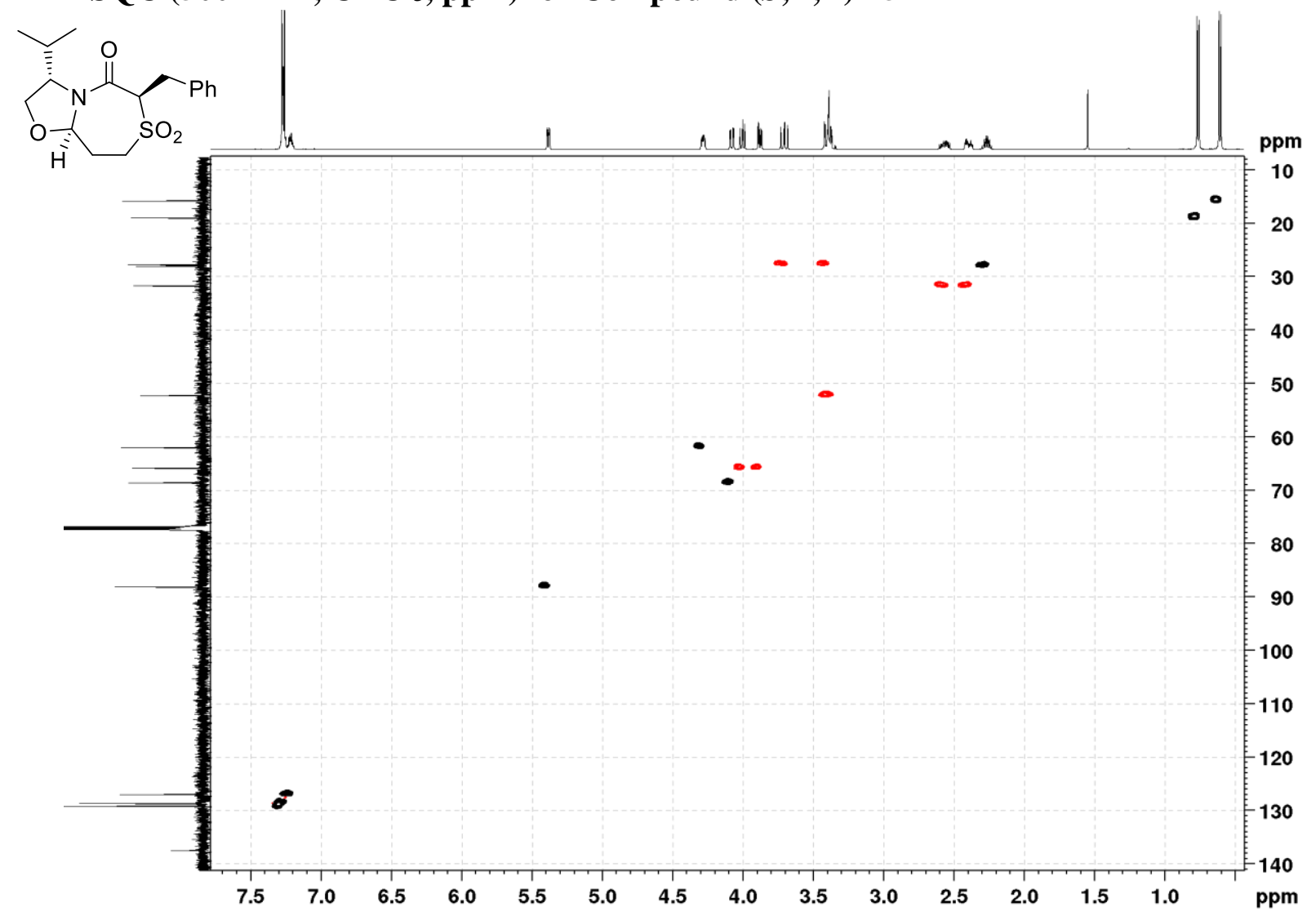


NOESY (500 MHz, $\left.\mathrm{CDCl}_{3}, \mathrm{ppm}\right)$ for Compound $(S, R, R)-15$

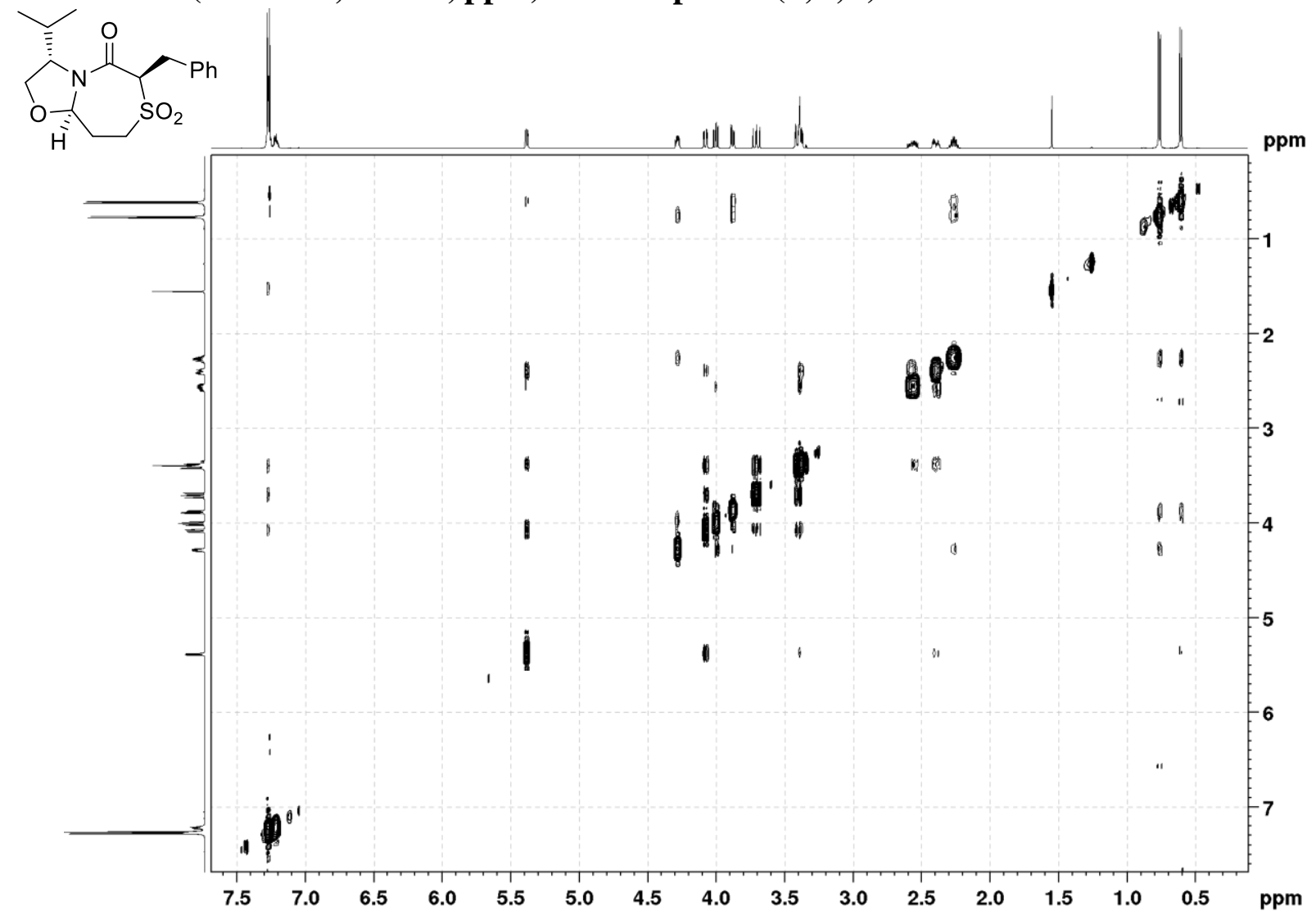

${ }^{1} \mathrm{H}$ NMR (500 MHz, $\left.\mathrm{CDCl}_{3}, \mathrm{ppm}\right)$ for Compound $(S, S, R)-15$

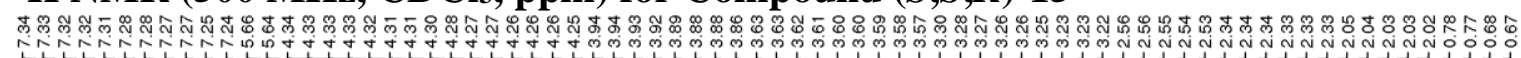<smiles>CC(C)[C@@H]1CO[C@@H]2CCS(=O)(=O)[C@H](Cc3ccccc3)C(=O)N21</smiles>

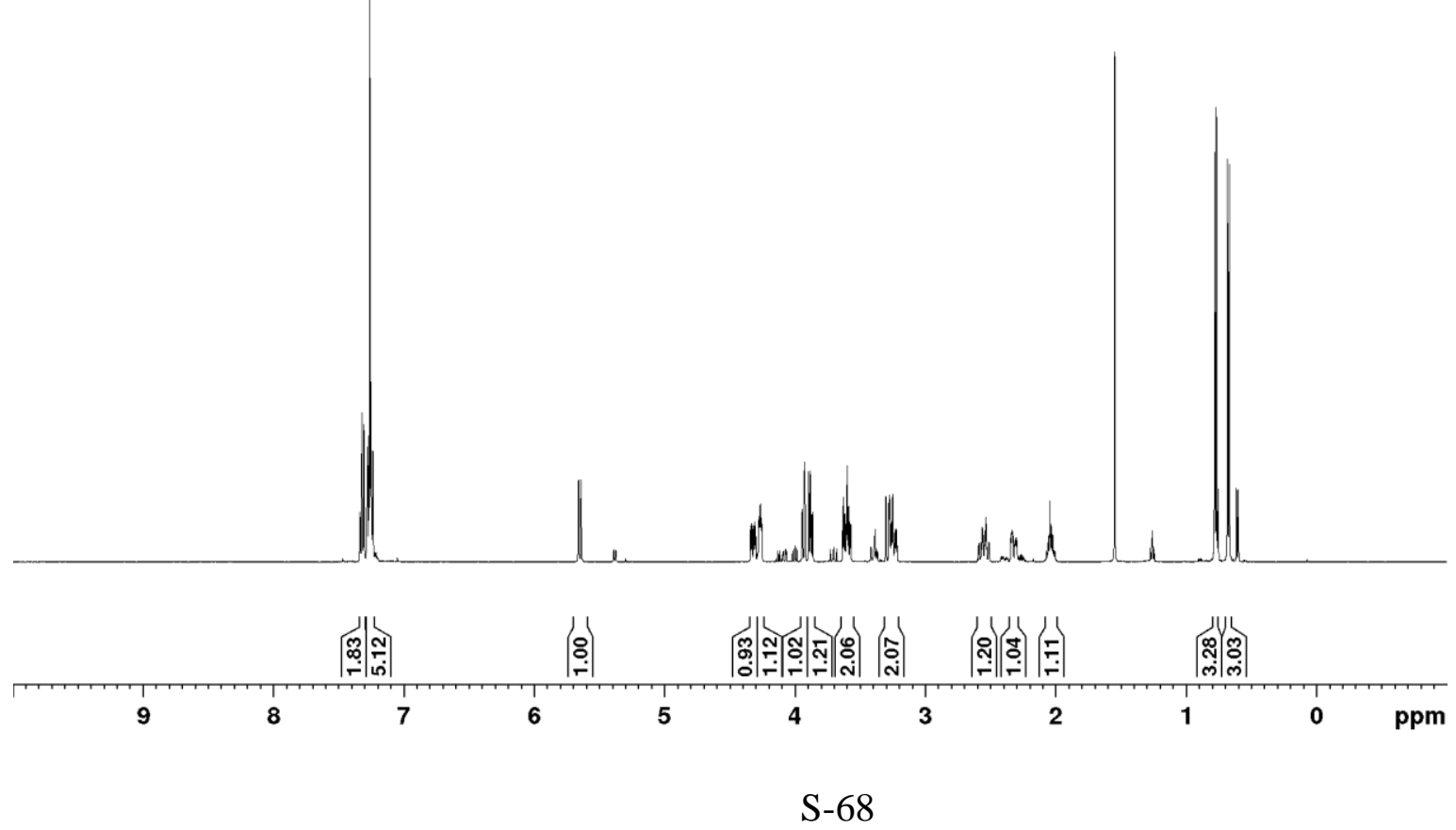


${ }^{13} \mathrm{C}$ NMR (126 MHz, CDCl3, ppm) for Compound $(S, S, R)-15$
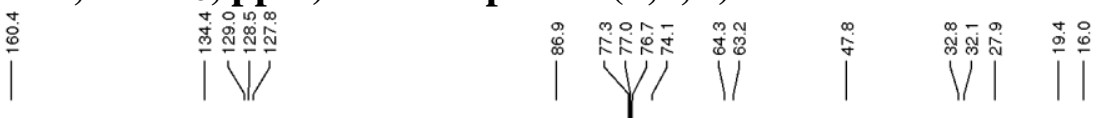<smiles>CC(C)[C@H]1COC2CC[R6](=O)(O)C(Cc3ccccc3)C(=O)N21</smiles>
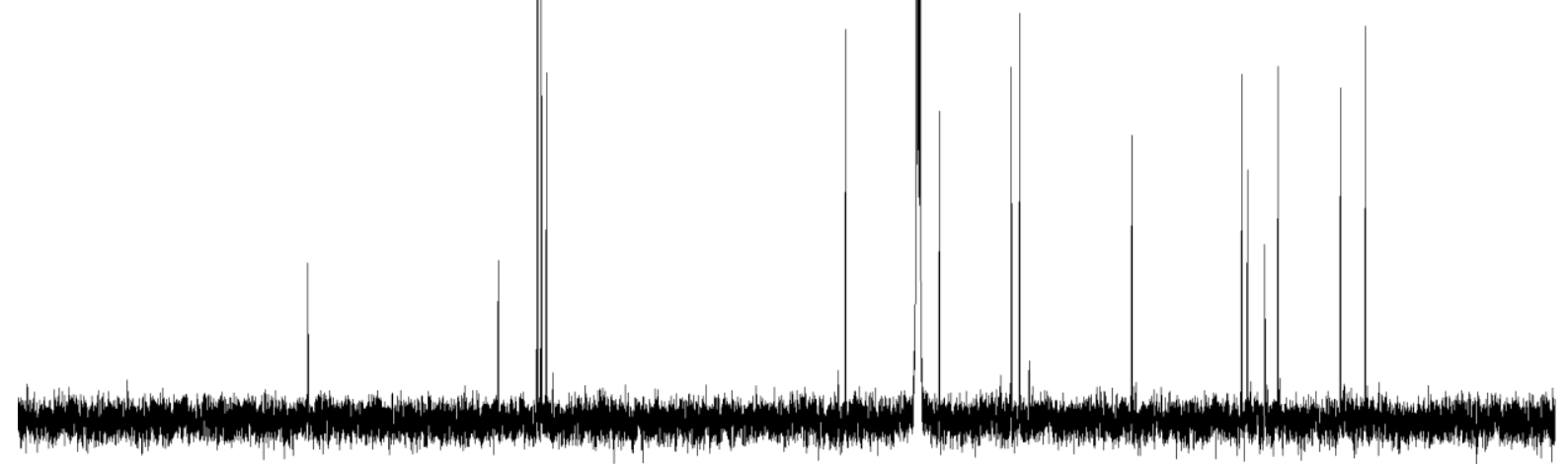

COSY (500 MHz, CDCl3, ppm) for Compound $(S, S, R)-15$

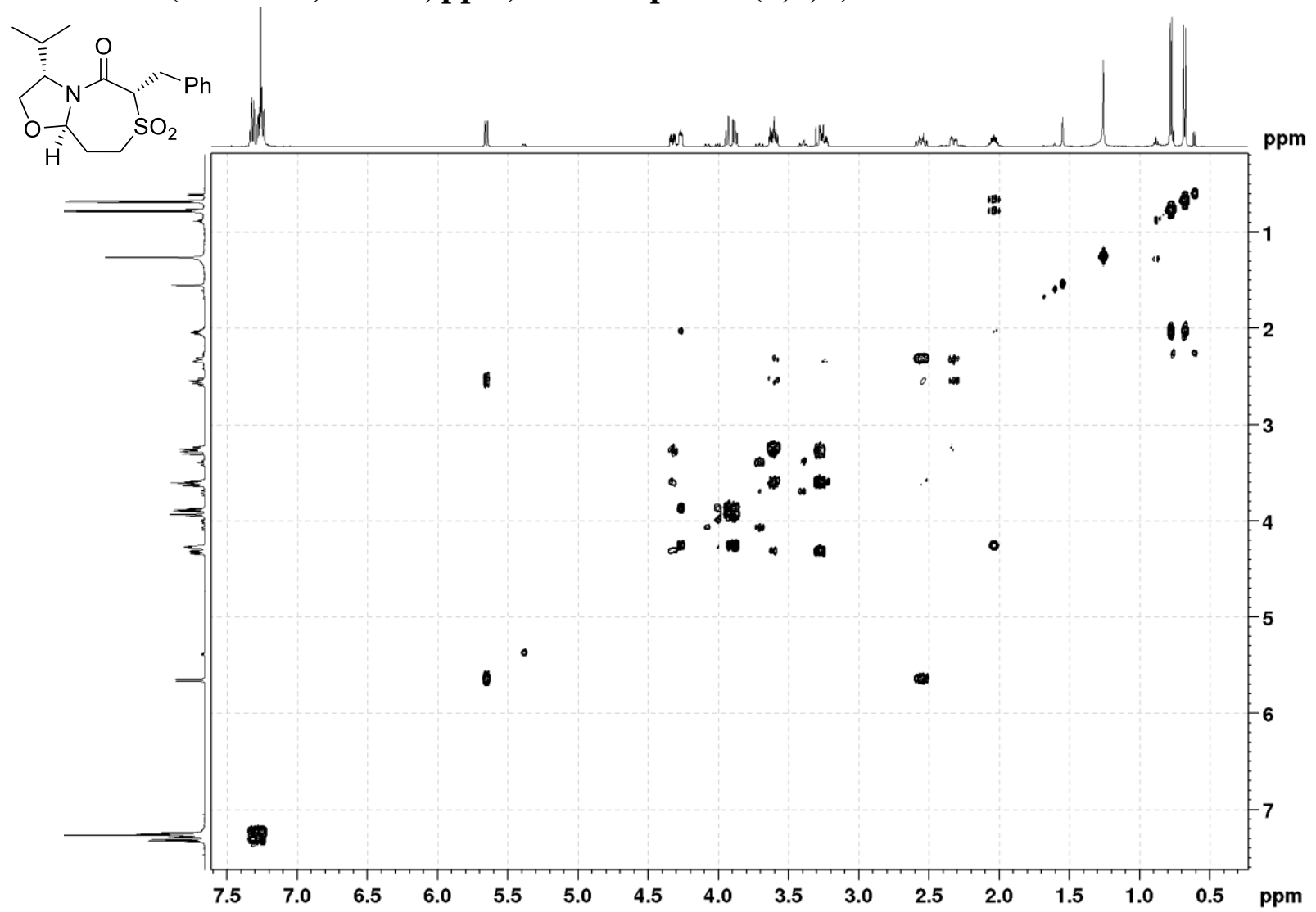

S-69 
HSQC (500 MHz, CDCl3, ppm) for Compound (S,S,R)-15

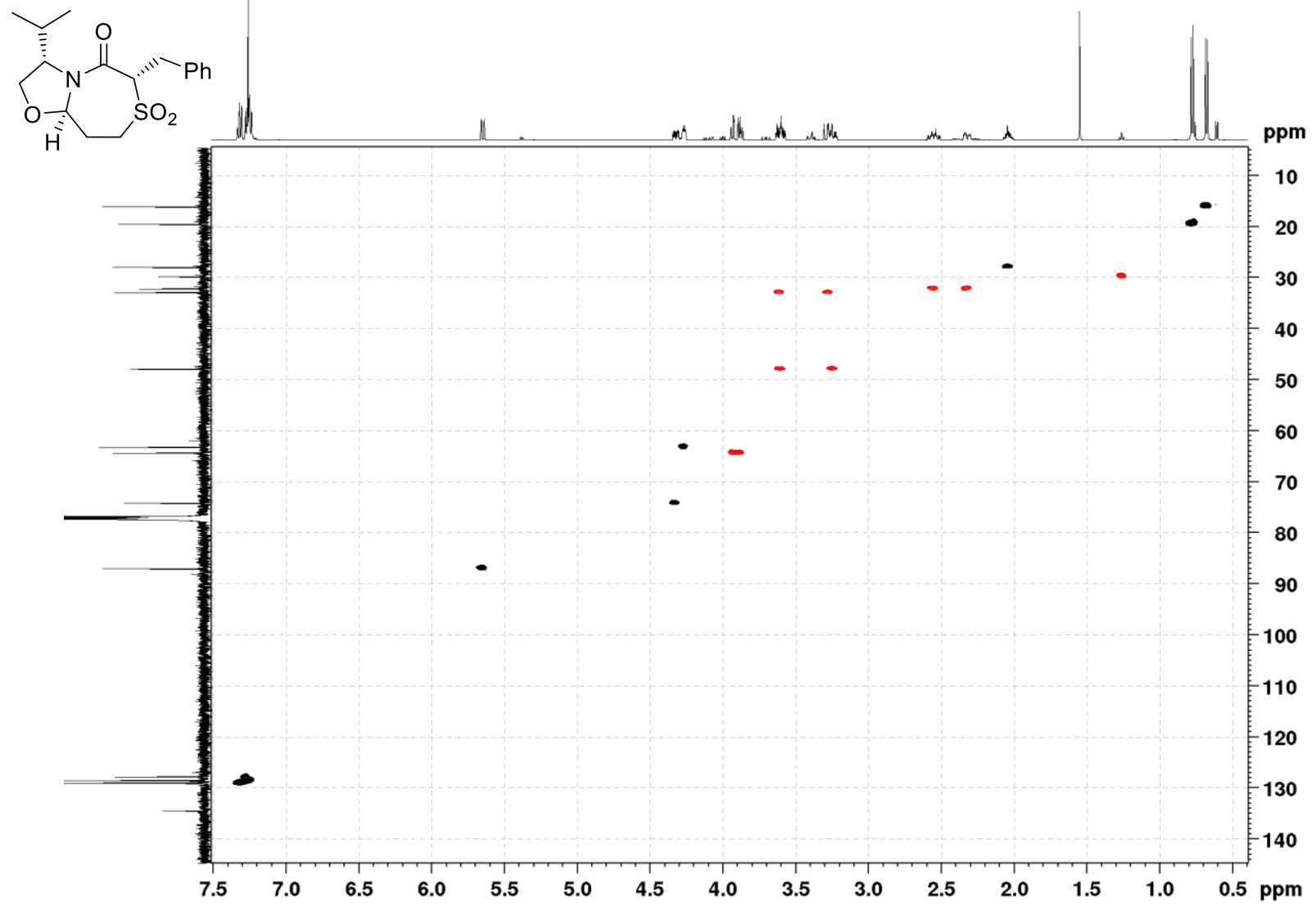

NOESY (500 MHz, $\left.\mathrm{CDCl}_{3}, \mathrm{ppm}\right)$ for Compound $(S, S, R)-15$

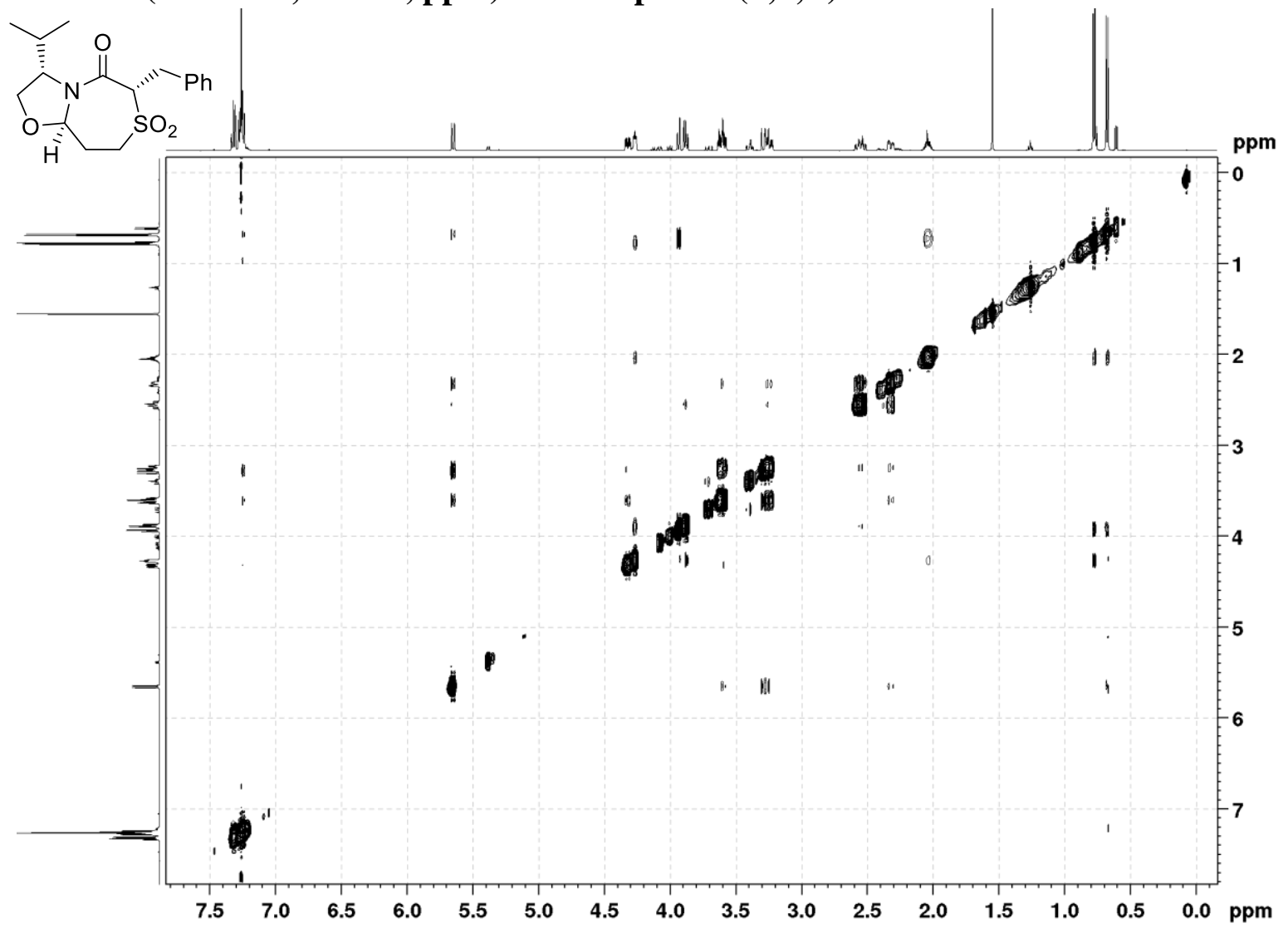

S-70 
${ }^{1} \mathrm{H}$ NMR (500 MHz, $\mathrm{CDCl}_{3}$, ppm) for Compound 16

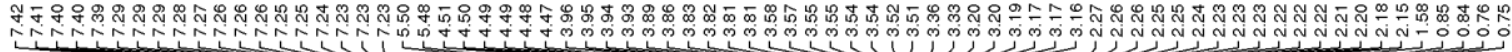<smiles></smiles>

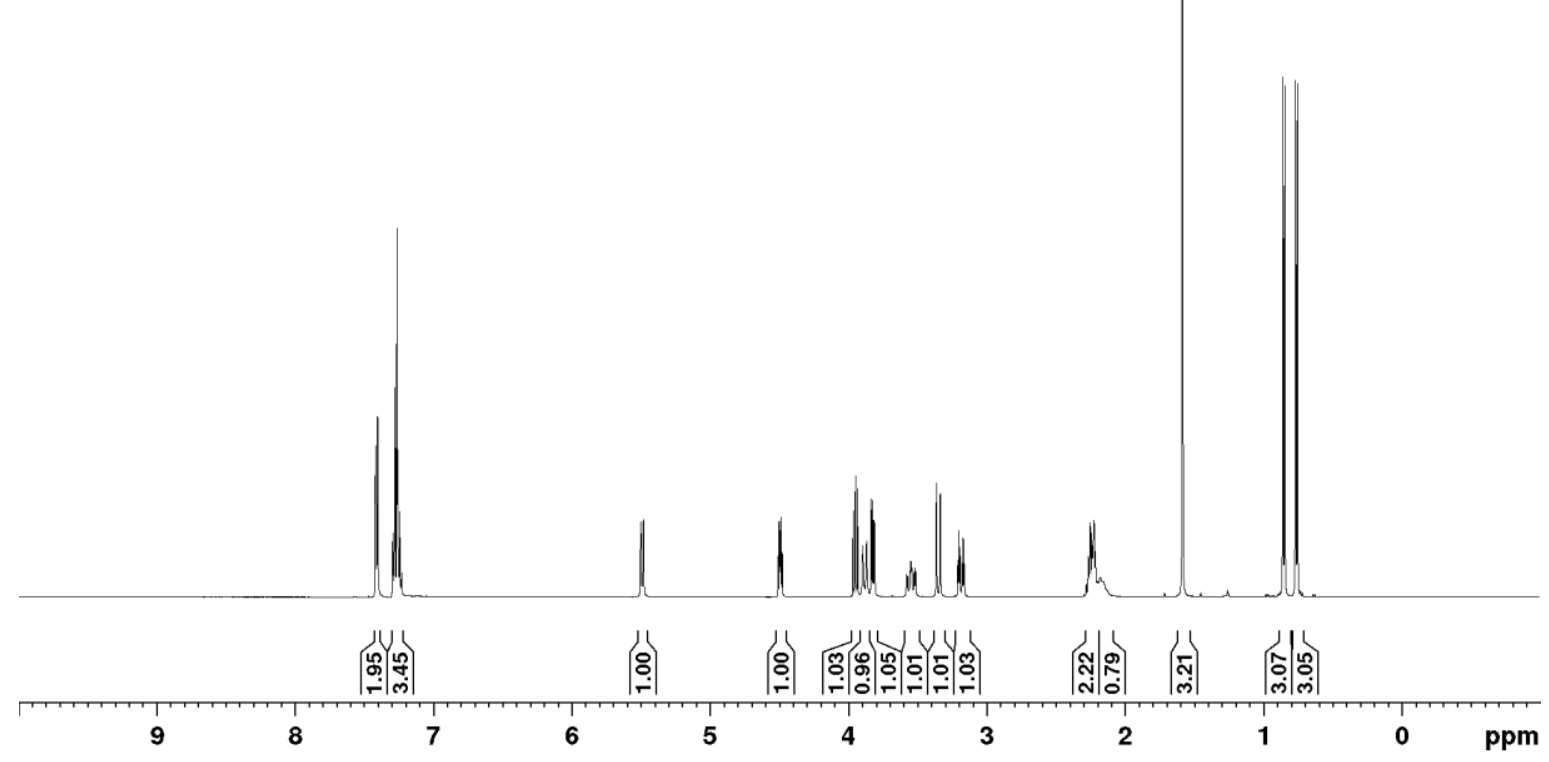

${ }^{13} \mathrm{C}$ NMR (126 MHz, $\mathrm{CDCl}_{3}$, ppm) for Compound 16

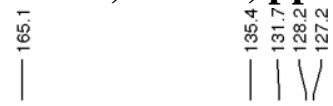<smiles></smiles>

H

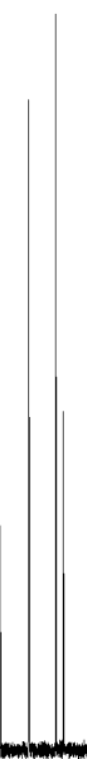


NOESY (500 MHz, $\mathrm{CDCl}_{3}$, ppm) for Compound 16

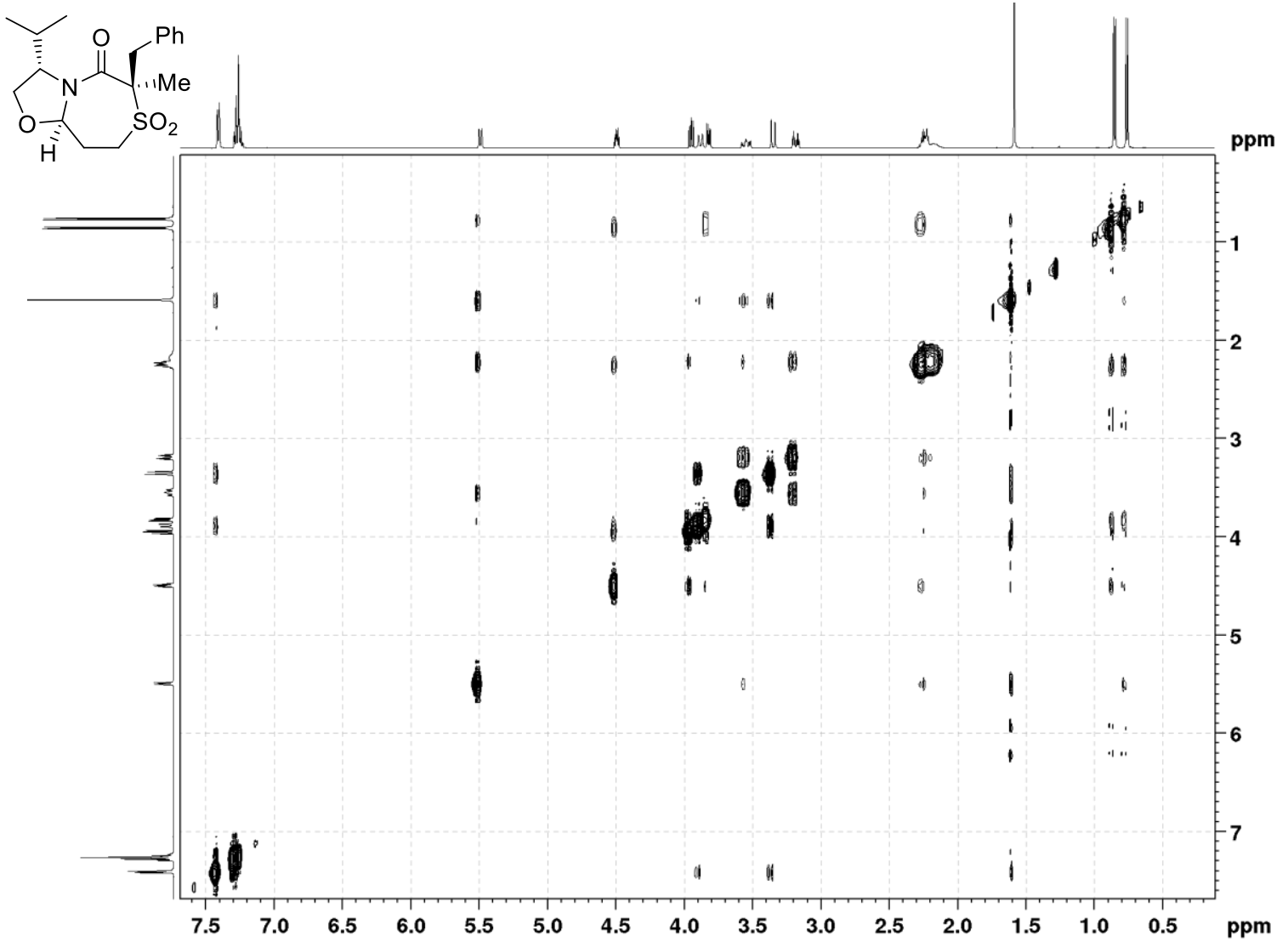

${ }^{1} \mathrm{H}$ NMR (500 MHz, $\left.\mathrm{CDCl}_{3}, \mathrm{ppm}\right)$ for Compound 17a

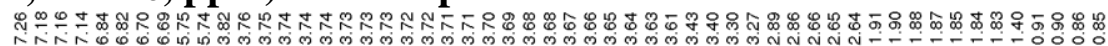

$\mathrm{WV} \longrightarrow$<smiles>COc1cccc2c1C[C@@](C)(C(=O)N[C@H](CO)C(C)C)C2</smiles>

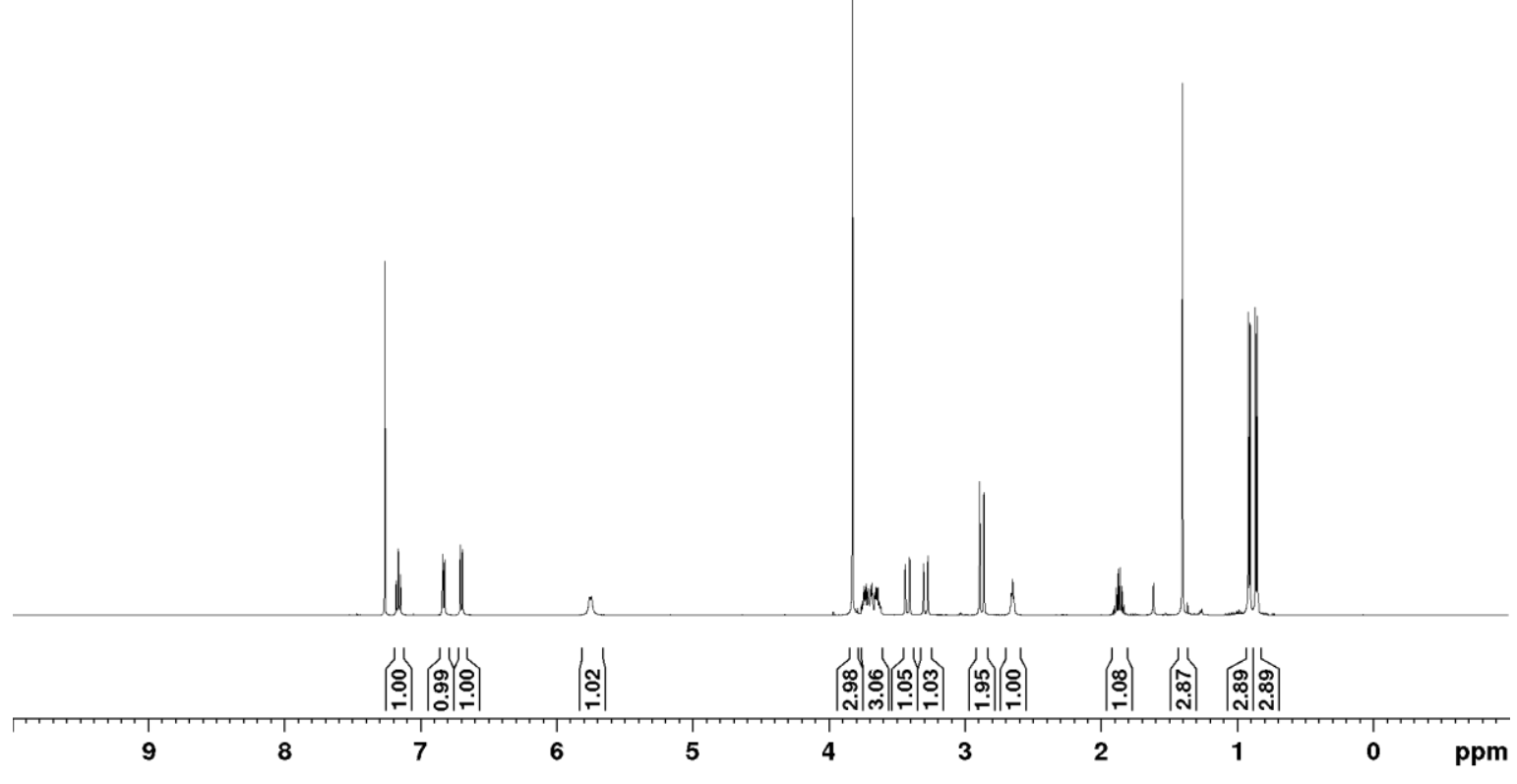

S-72 


\section{${ }^{13} \mathrm{C}$ NMR (126 $\left.\mathrm{MHz}, \mathrm{CDCl}_{3}, \mathrm{ppm}\right)$ for Compound 17a}
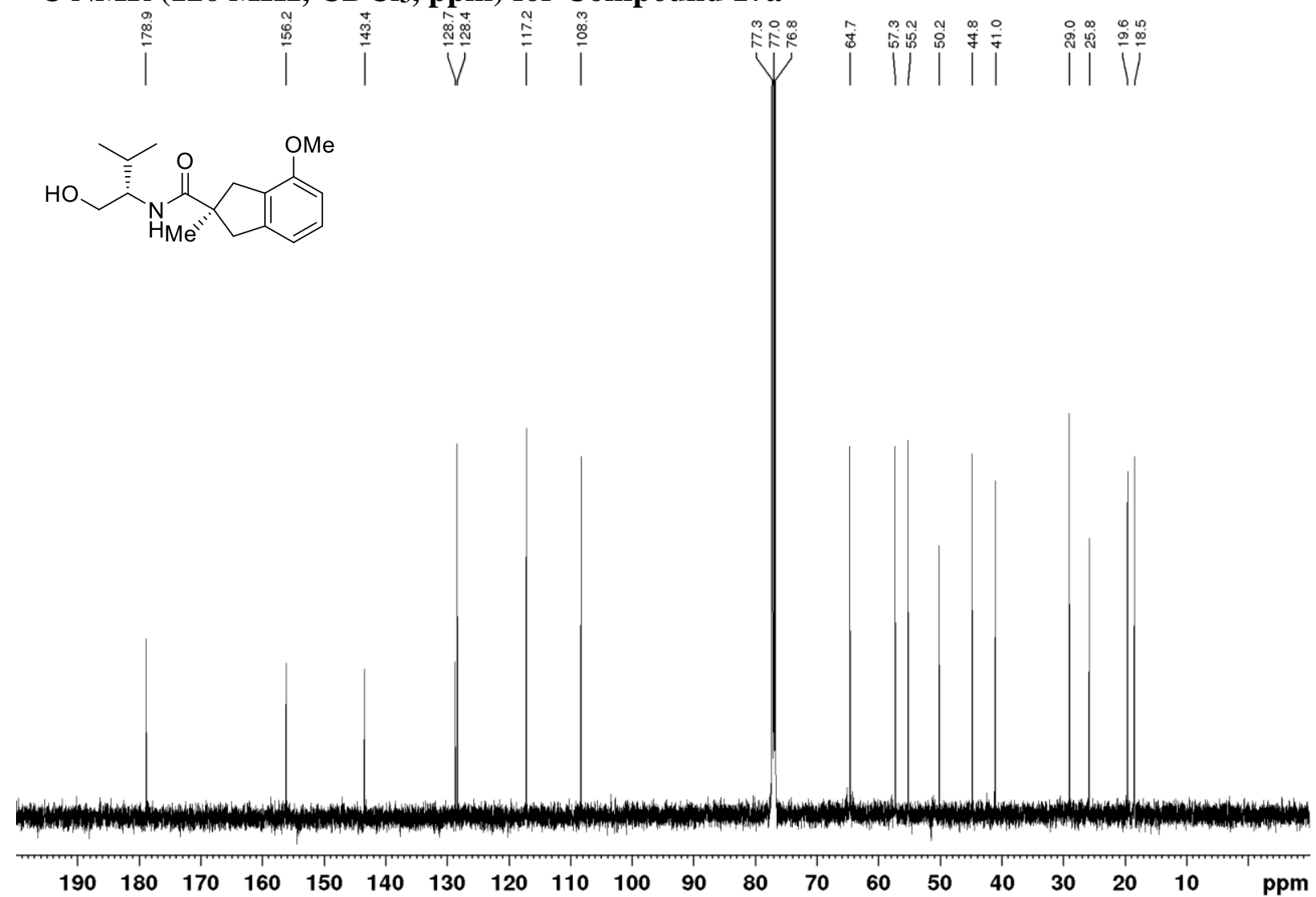

${ }^{1} \mathrm{H}$ NMR (500 MHz, CDCl3, ppm) for Compound 17b

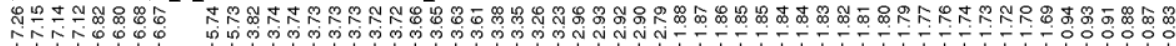<smiles>CCC1(C(=O)N[C@@H](CO)C(C)C)Cc2cccc(OC)c2C1</smiles>

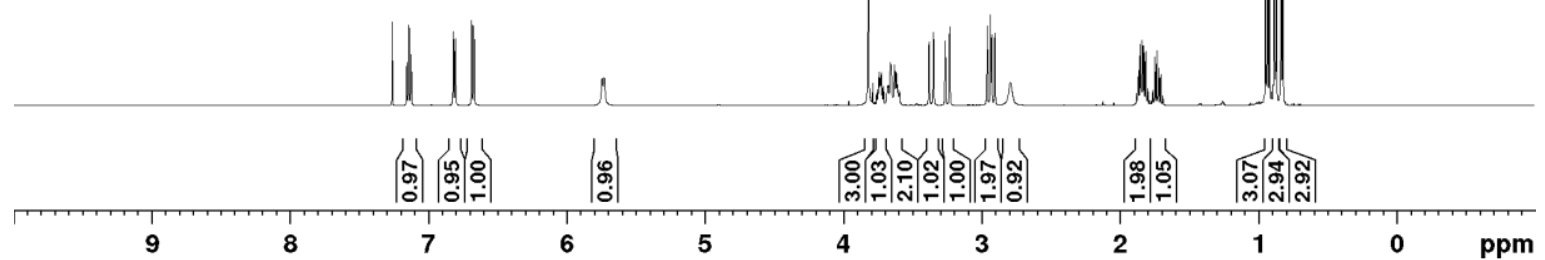

S-73 


\section{${ }^{13} \mathrm{C}$ NMR (126 MHz, $\mathrm{CDCl}_{3}$, ppm) for Compound 17b}

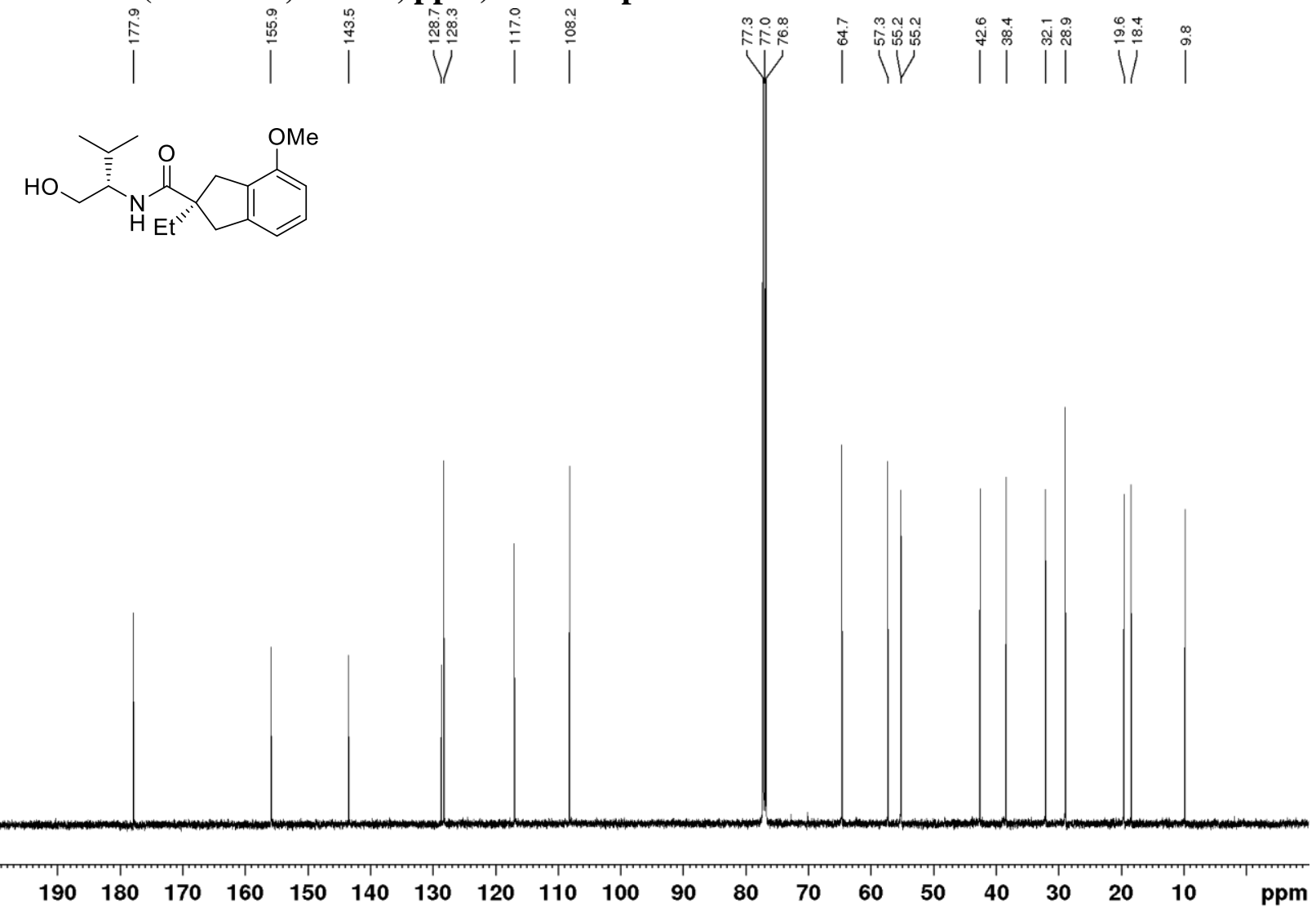

${ }^{1} \mathrm{H}$ NMR (500 MHz, CDCl3, ppm) for Compound 17c

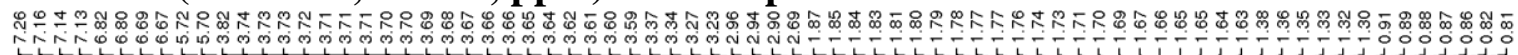<smiles>CCC[C@]1(C(=O)N[C@H](CO)C(C)C)Cc2cccc(OC)c2C1</smiles>

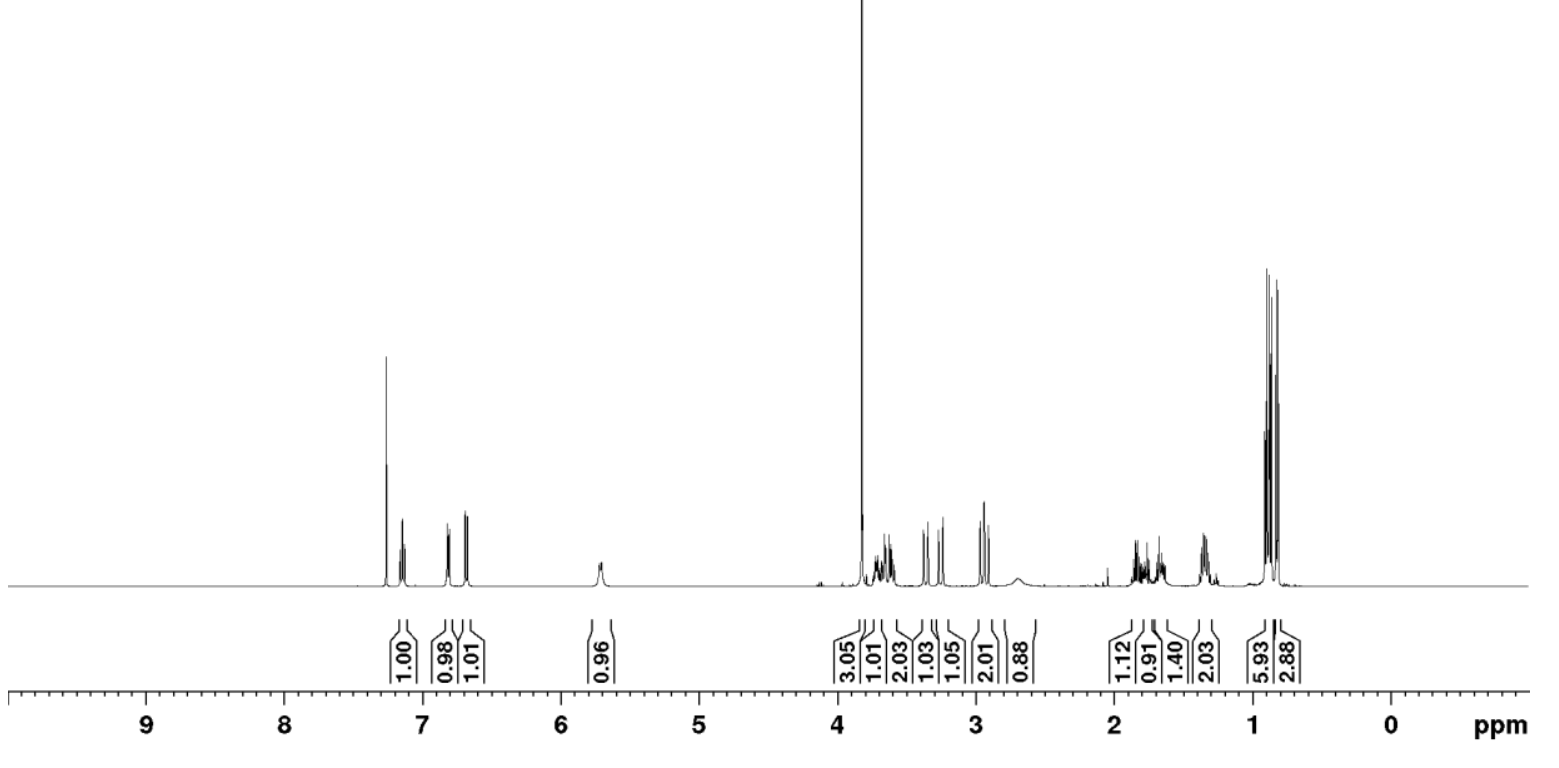




\section{${ }^{13} \mathrm{C}$ NMR (126 MHz, $\left.\mathrm{CDCl}_{3}, \mathrm{ppm}\right)$ for Compound $17 \mathrm{c}$}

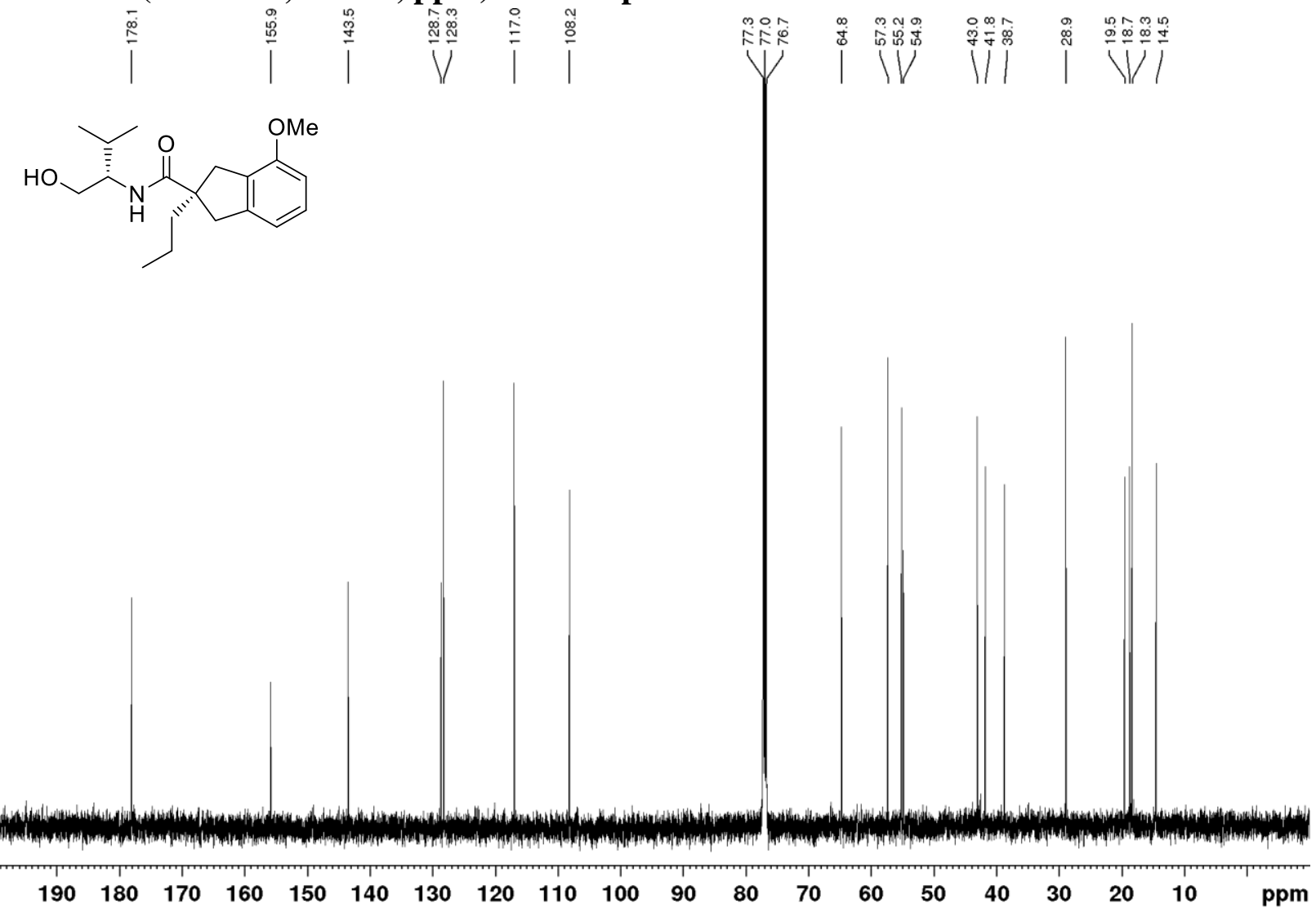

${ }^{1} \mathrm{H}$ NMR (500 MHz, CDCl3, ppm) for Compound 17d

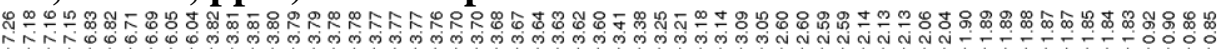

1)i<smiles>C#CC[C@]1(C(=O)N[C@H](CO)C(C)C)Cc2cccc(OC)c2C1</smiles>

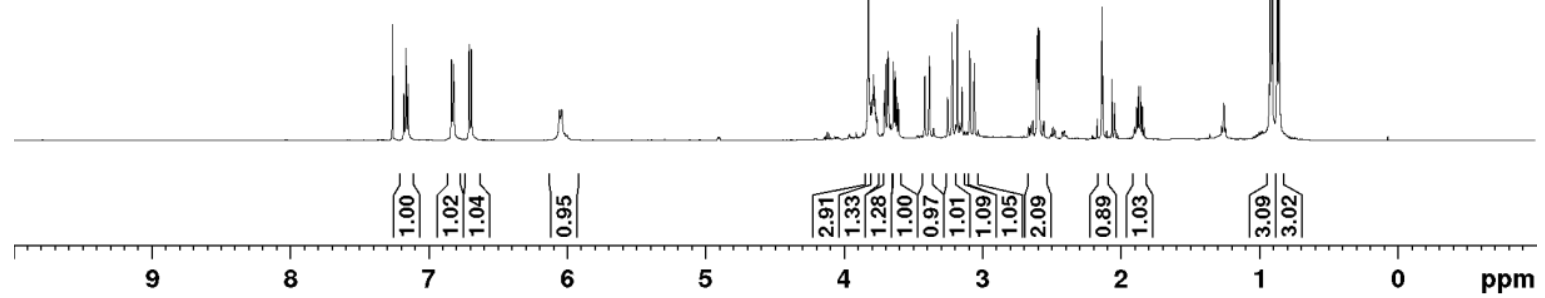




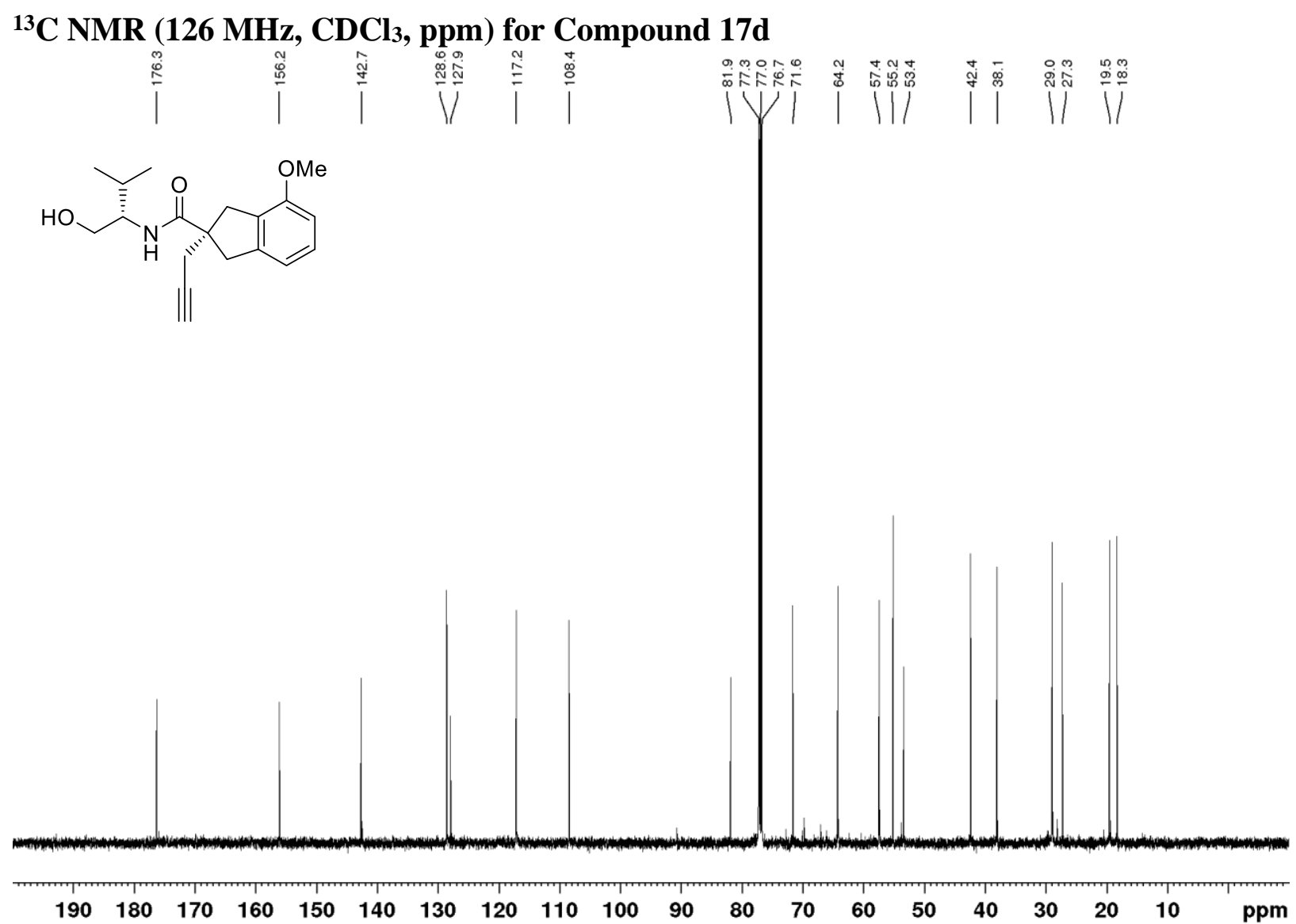

${ }^{1} \mathrm{H}$ NMR (500 MHz, CDCl3, ppm) for Compound 17e

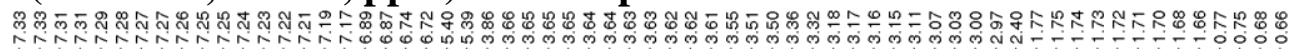

$\mathrm{V} / \mathrm{V} / \mathrm{N}$<smiles>COc1cccc2c1C[C@H](C(=O)N[C@H](CO)C(C)C)C2</smiles>

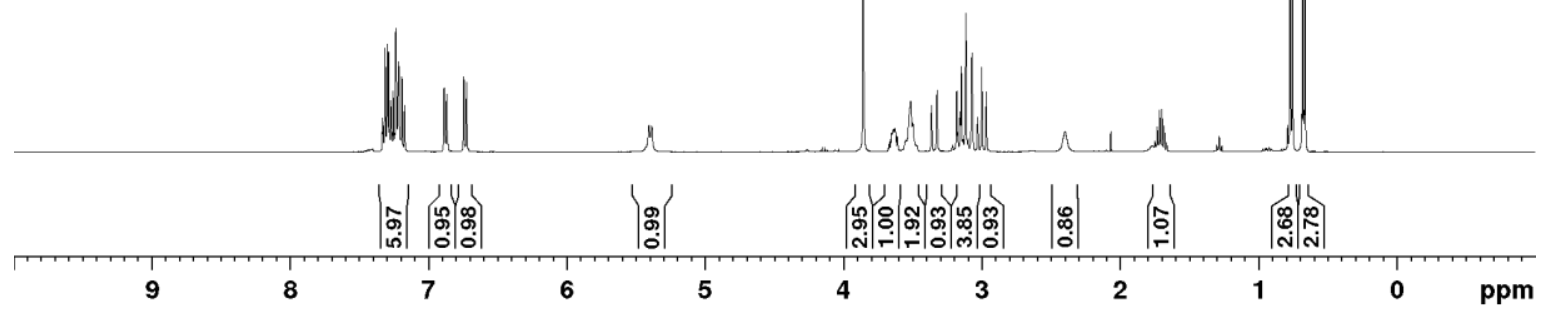

S-76 


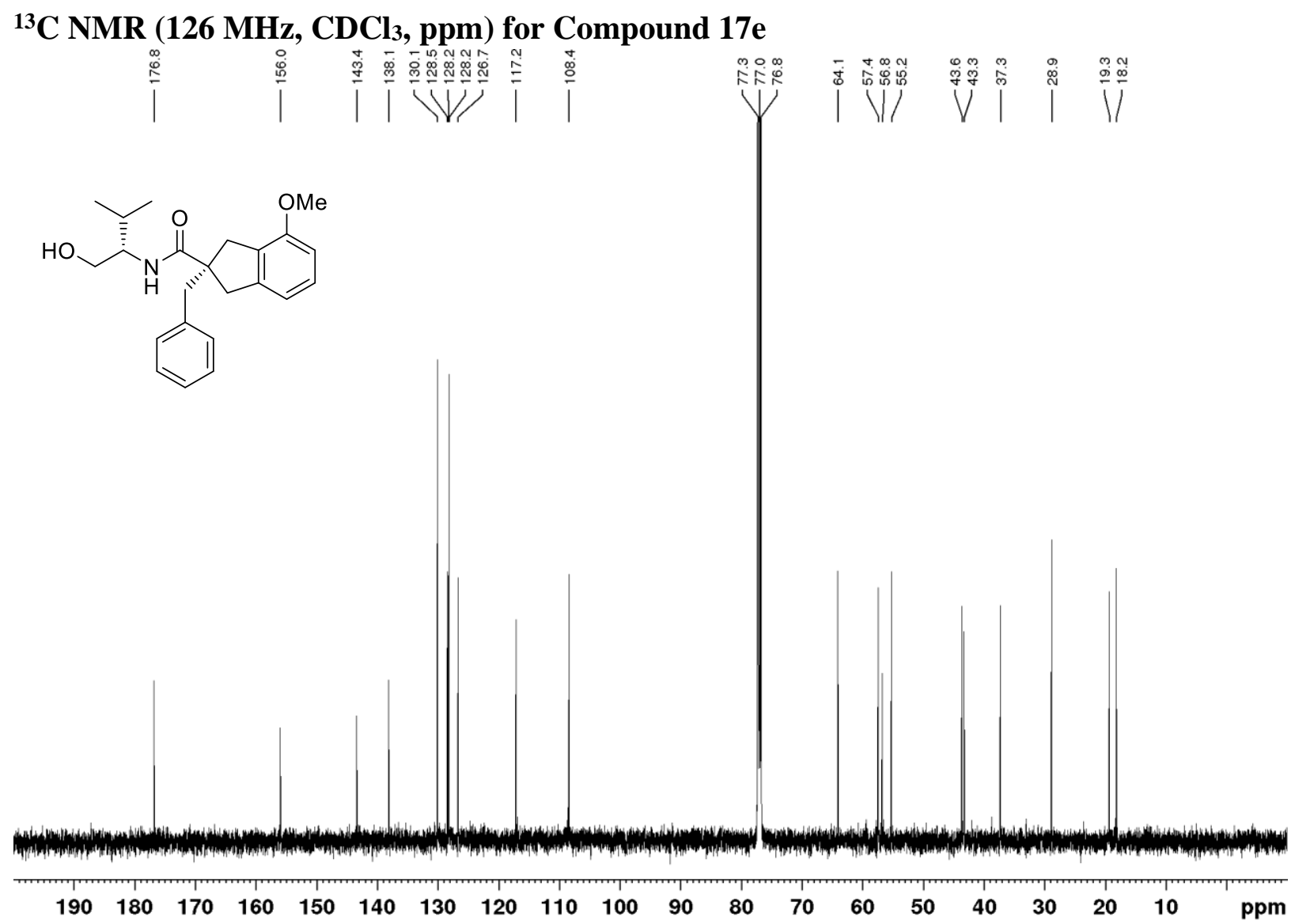

${ }^{1} \mathrm{H}$ NMR (500 MHz, CDCl3, ppm) for Compound $17 \mathrm{f}$

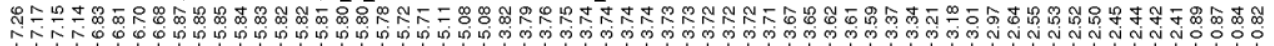
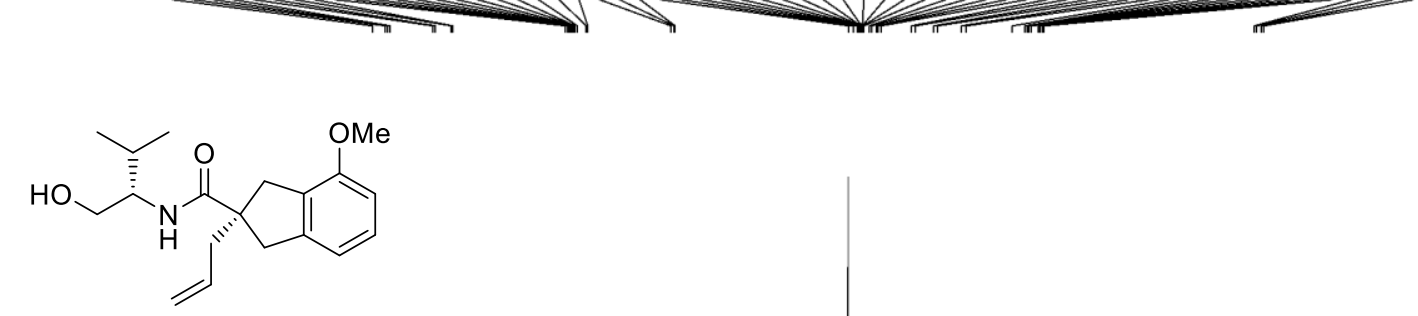

8

(ำ:
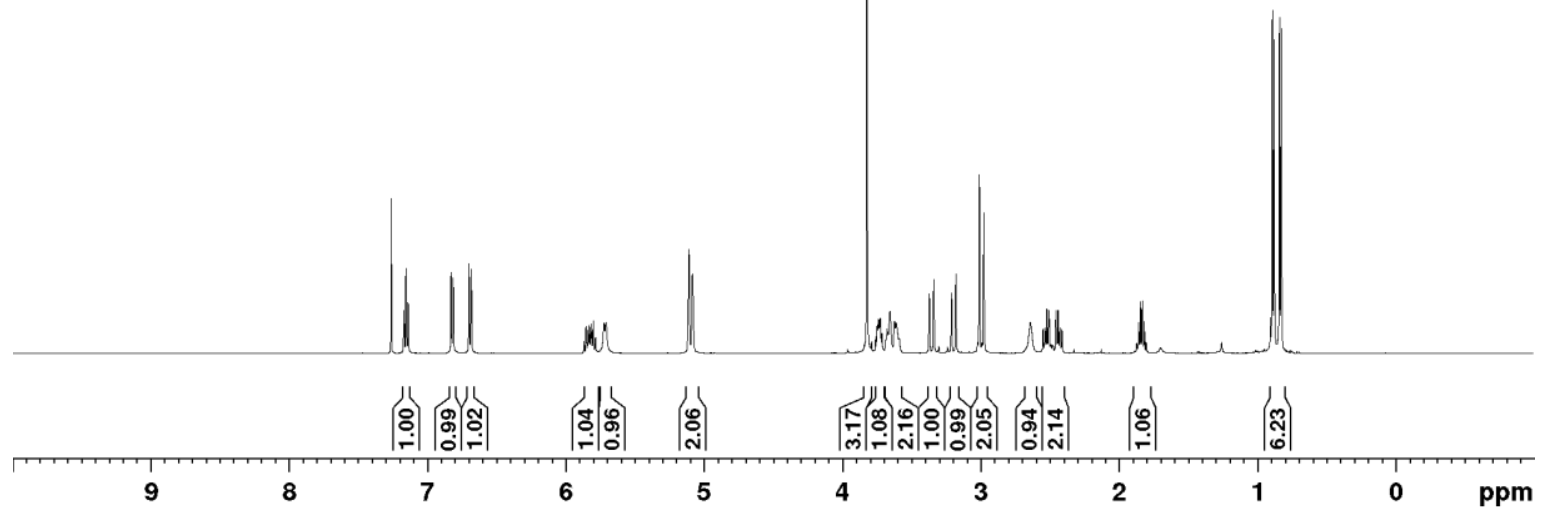


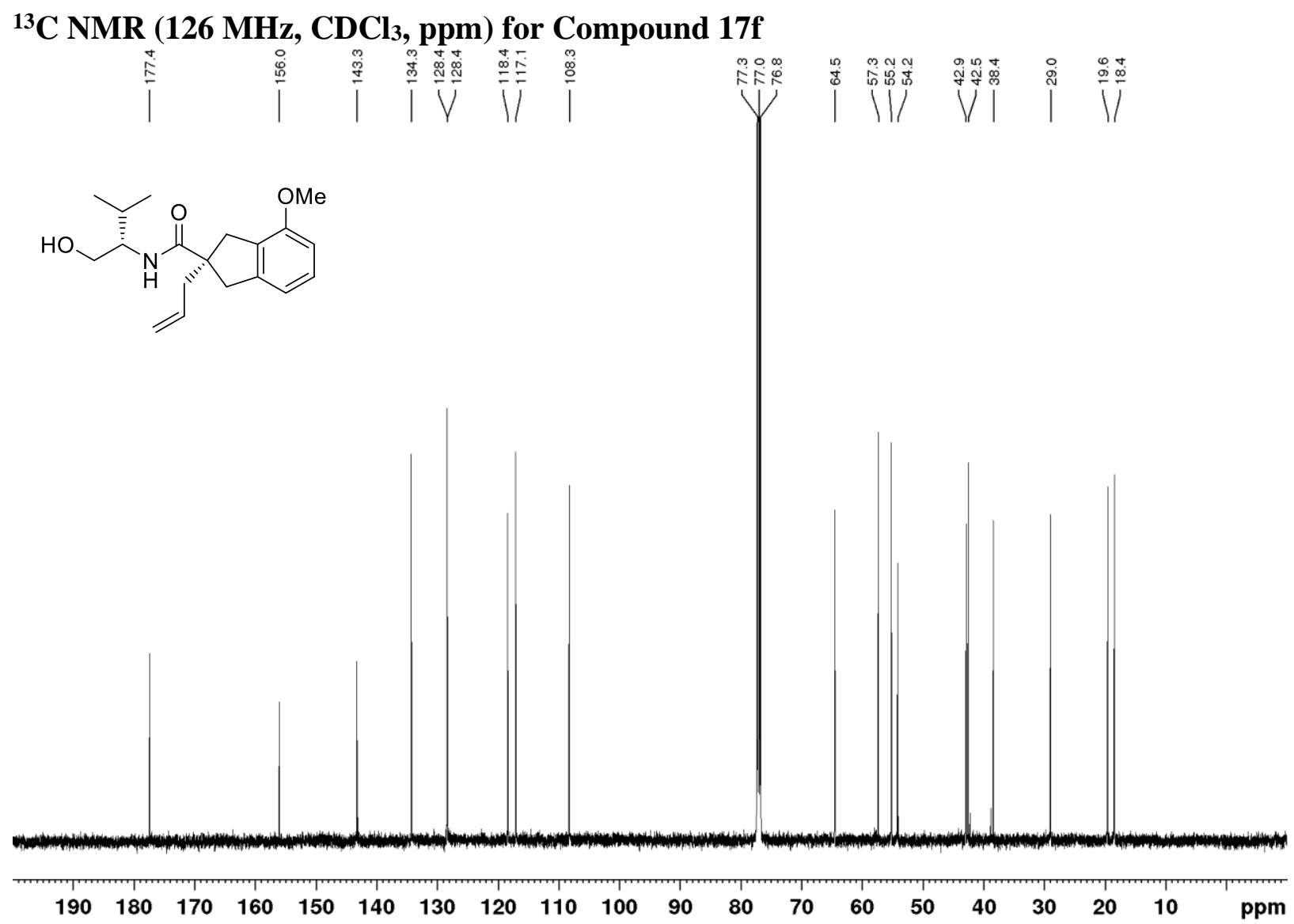

${ }^{1} \mathrm{H}$ NMR (500 MHz, CDCl3, ppm) for Compound $17 \mathrm{~g}$

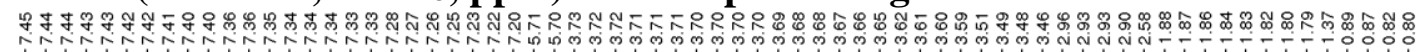
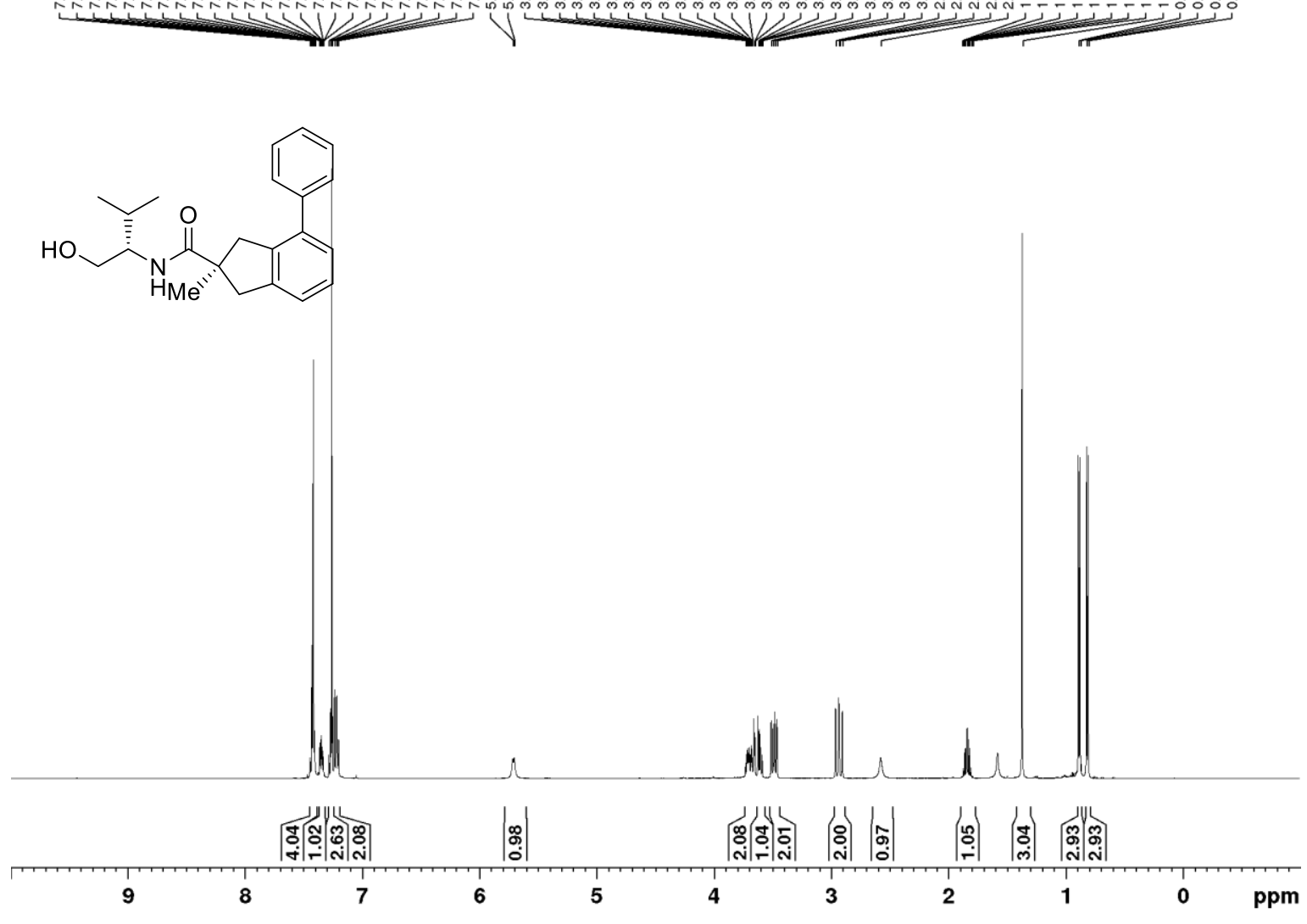

S-78 


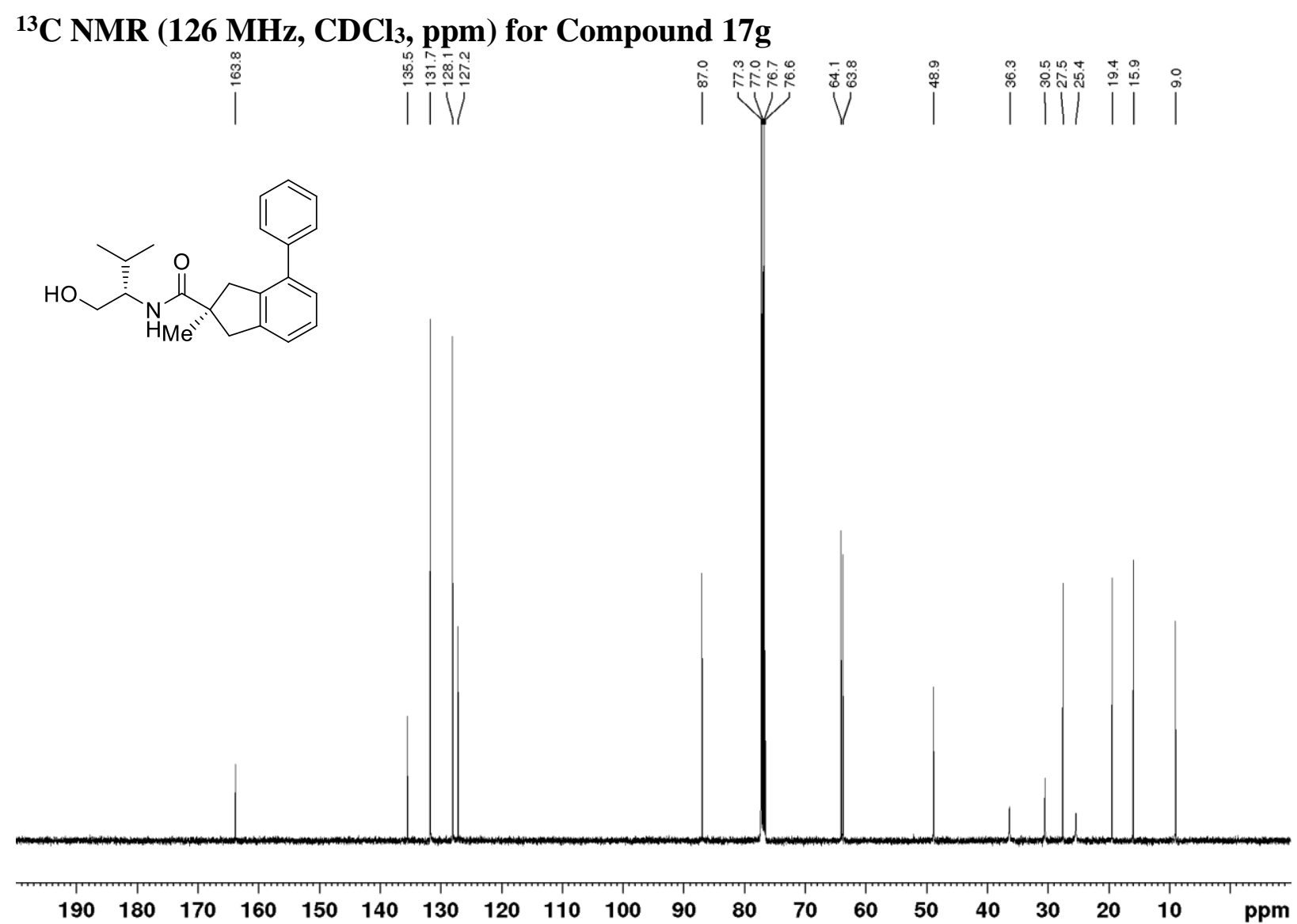

${ }^{1} \mathrm{H}$ NMR (500 MHz, CDCl3, ppm) for Compound 17h

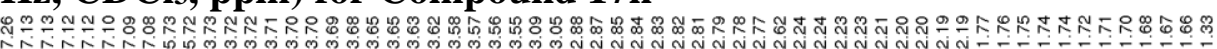<smiles>CC(C)[C@H](CO)NC(=O)[C@]1(C)CCc2ccccc2C1</smiles>

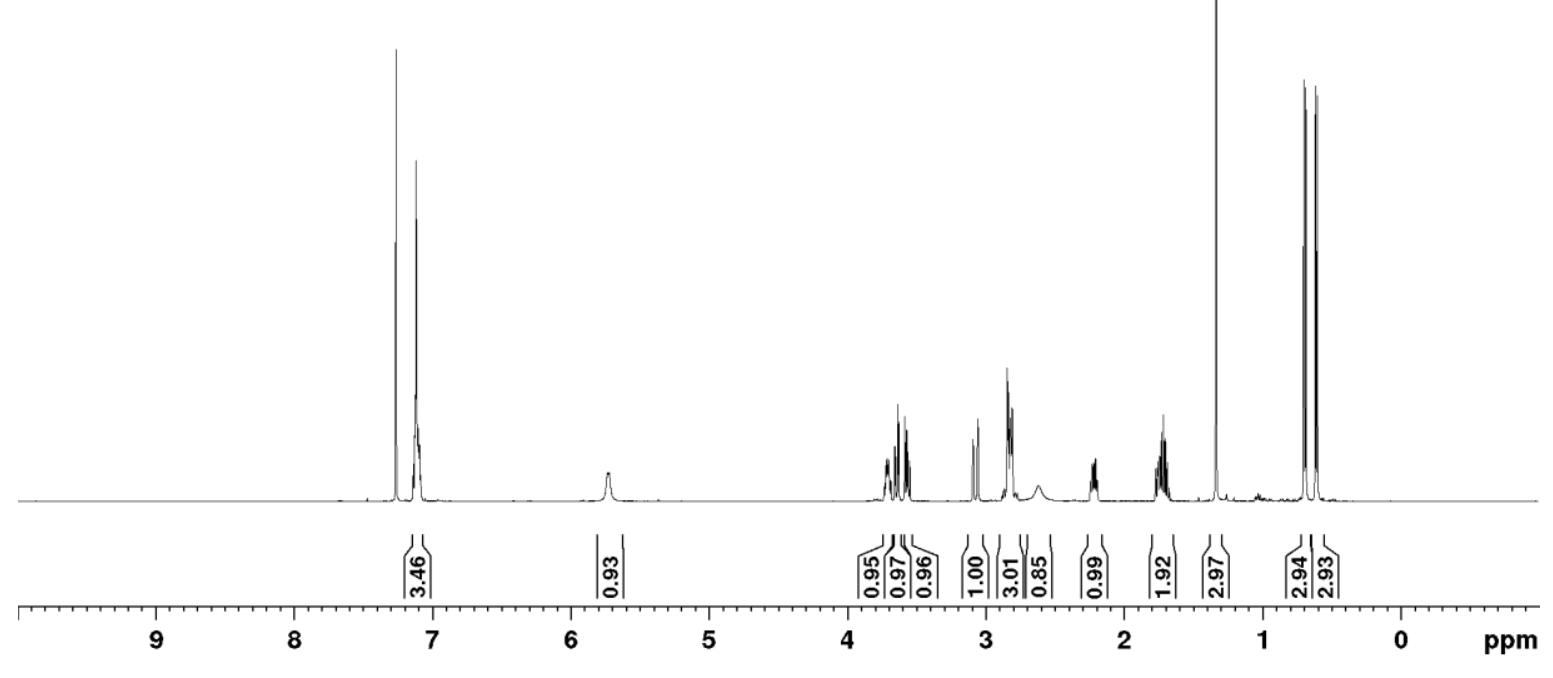




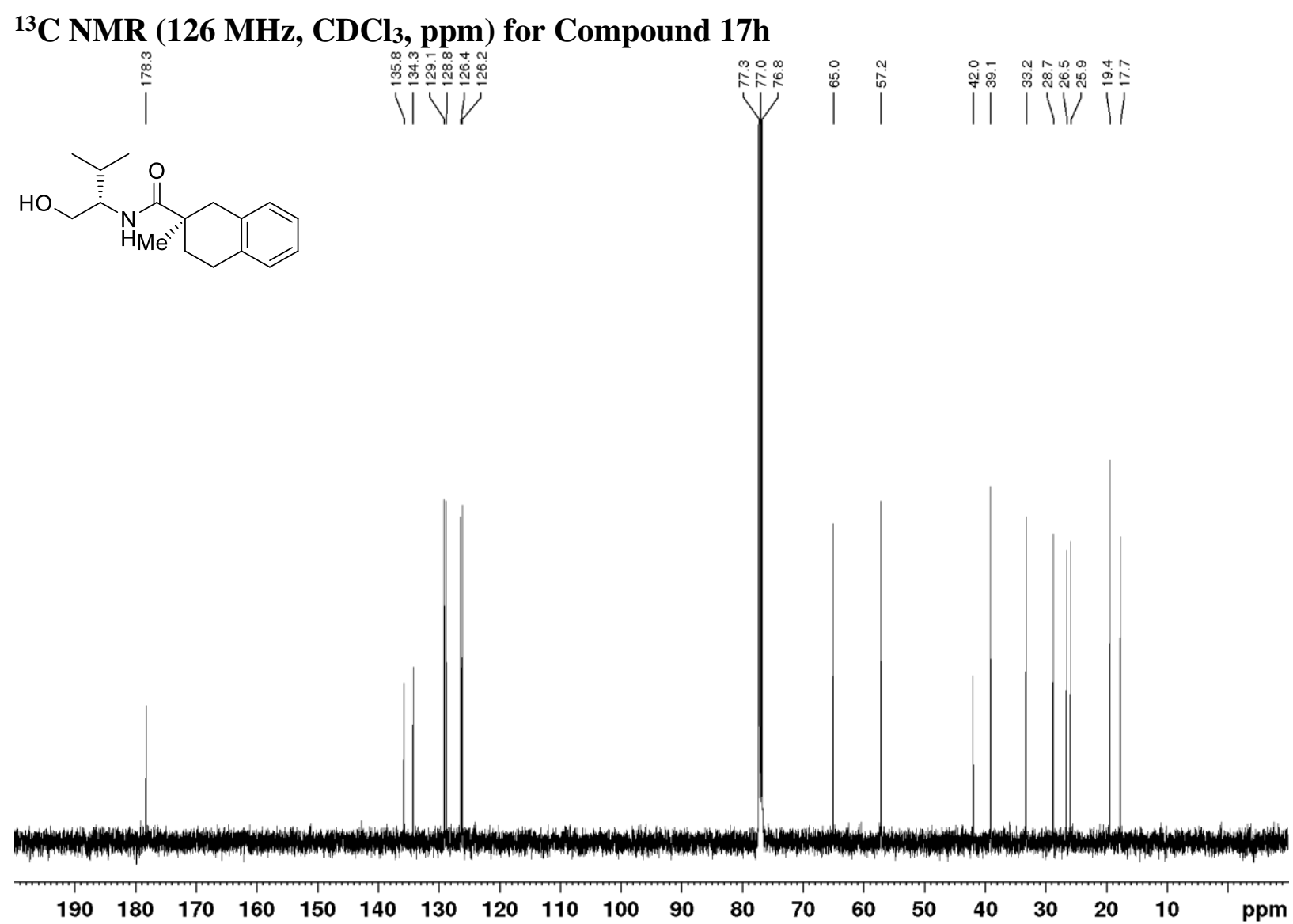

${ }^{1} \mathrm{H}$ NMR (500 MHz, $\left.\mathrm{CDCl}_{3}, \mathrm{ppm}\right)$ for Compound 17i

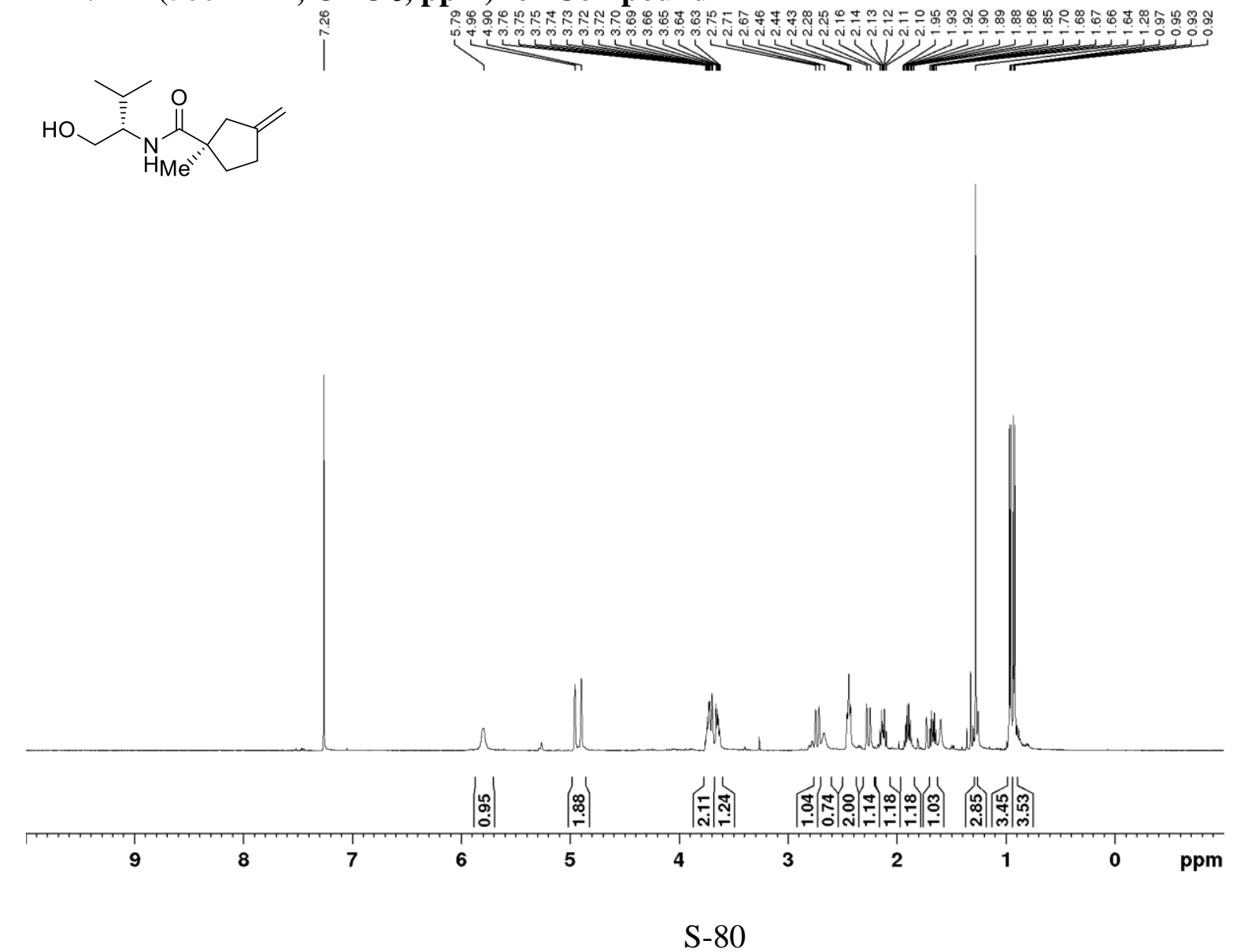




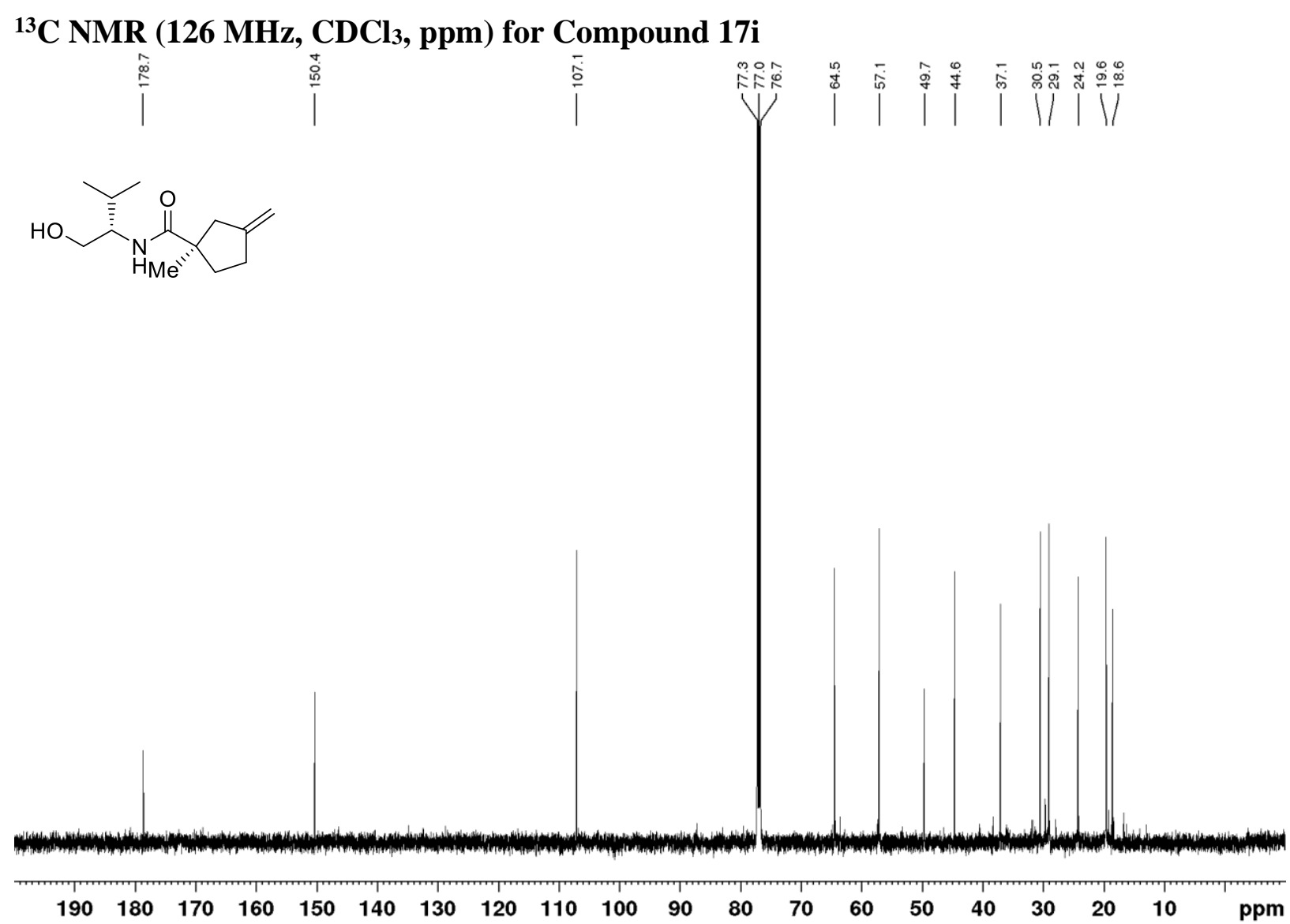

${ }^{1} \mathrm{H}$ NMR (500 MHz, CDCl3, ppm) for Compound 19
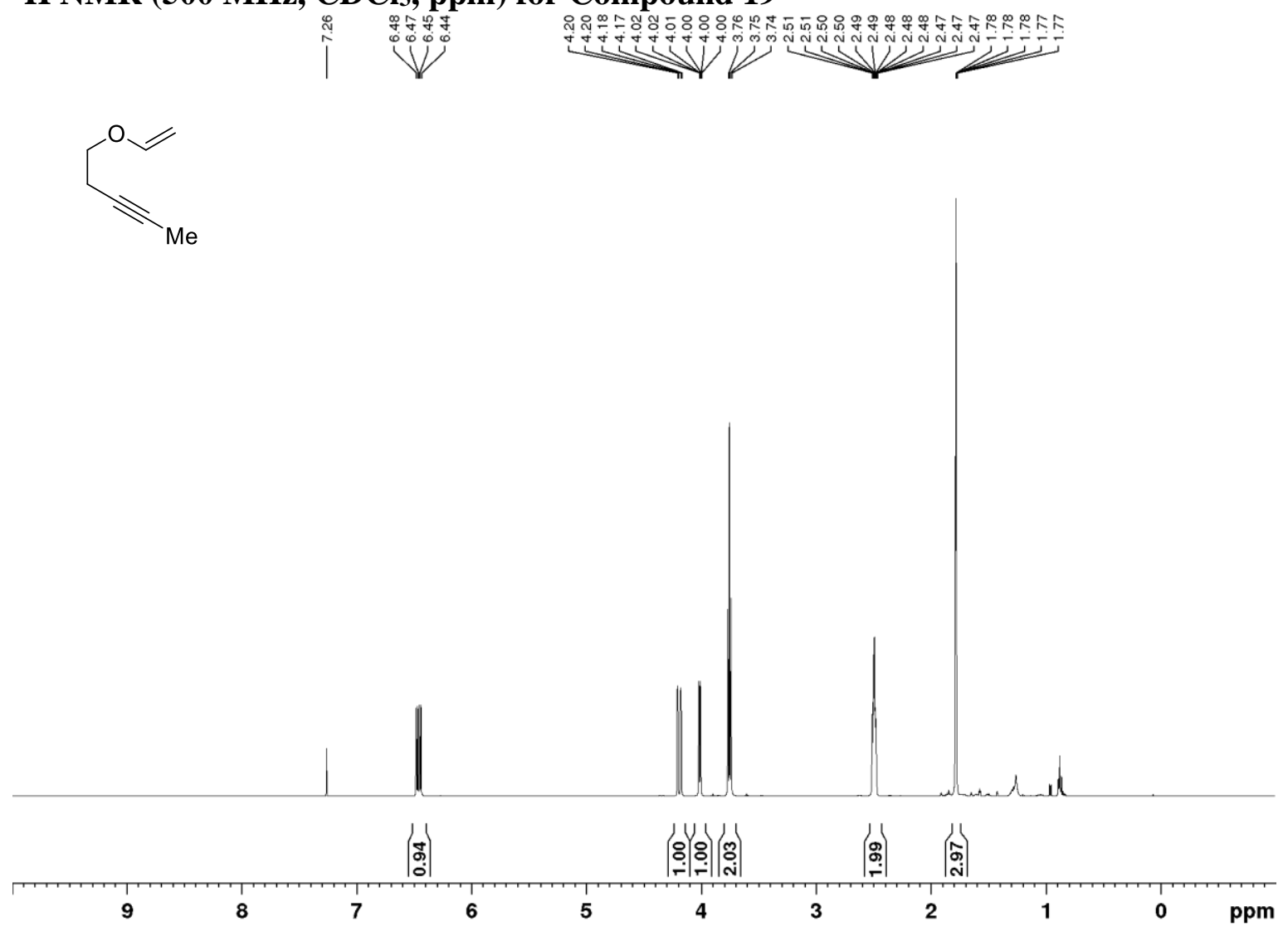
${ }^{13} \mathrm{C}$ NMR (126 MHz, $\mathrm{CDCl}_{3}$, ppm) for Compound 19
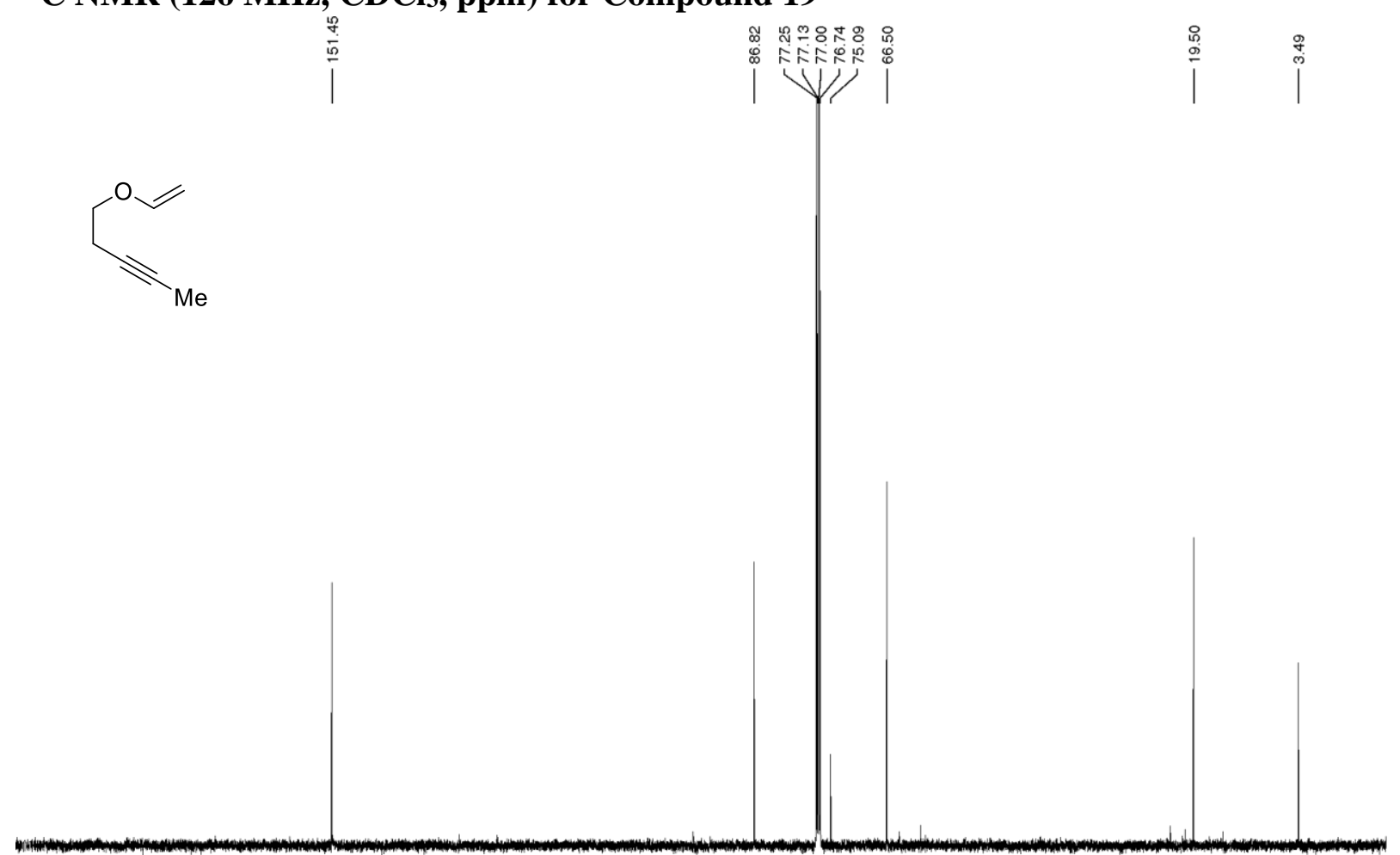

$\begin{array}{lllllllllllllllllllllll}190 & 180 & 170 & 160 & 150 & 140 & 130 & 120 & 110 & 100 & 90 & 80 & 70 & 60 & 50 & 40 & 30 & 20 & 10 & \text { ppm }\end{array}$

${ }^{1} \mathrm{H}$ NMR (500 MHz, CDCl 3 , ppm) for Compound 20

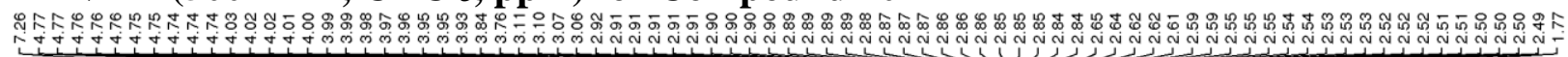

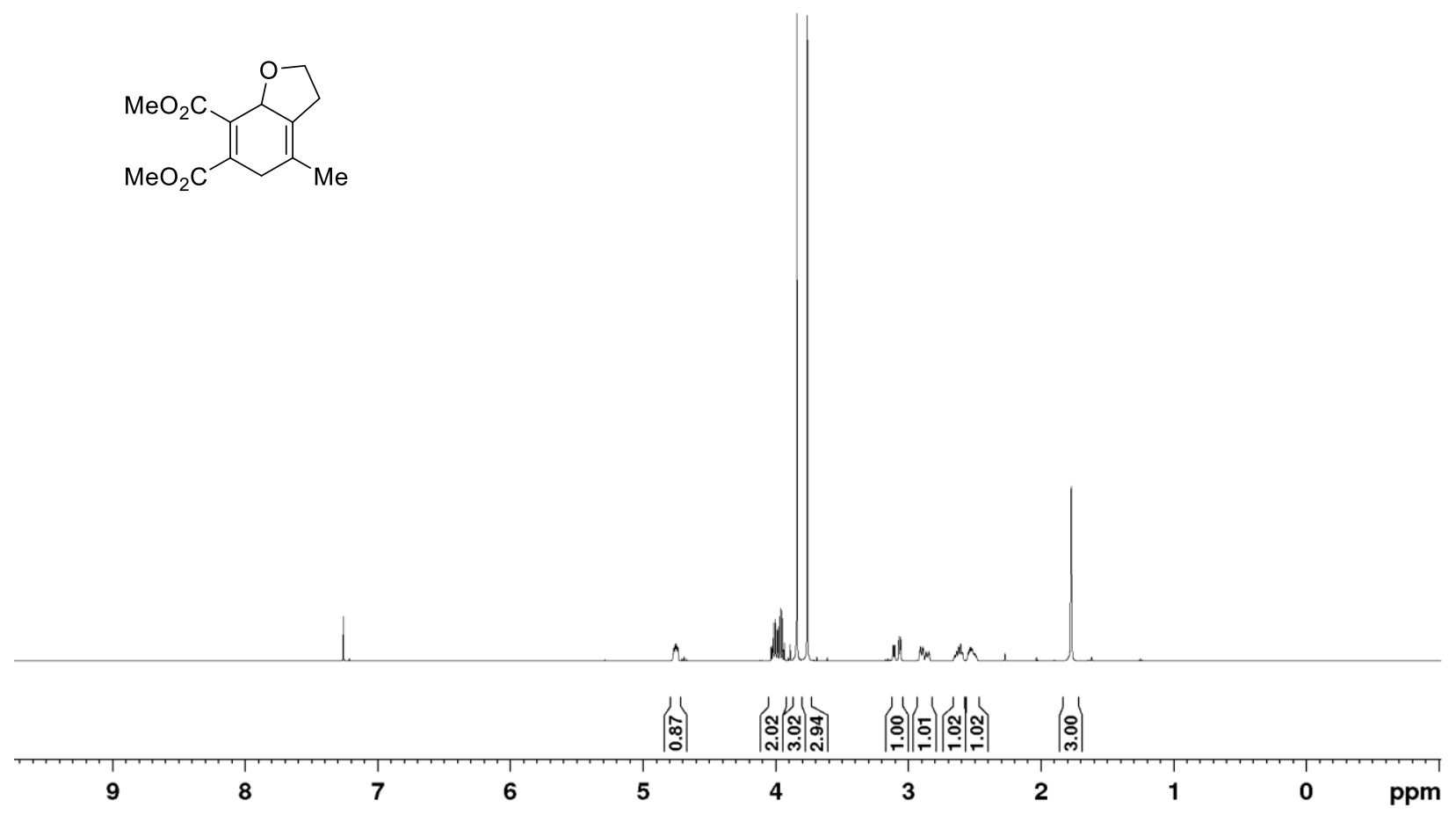


${ }^{13} \mathrm{C}$ NMR (126 MHz, $\left.\mathrm{CDCl}_{3}, \mathrm{ppm}\right)$ for Compound 20

$\prod^{1}$
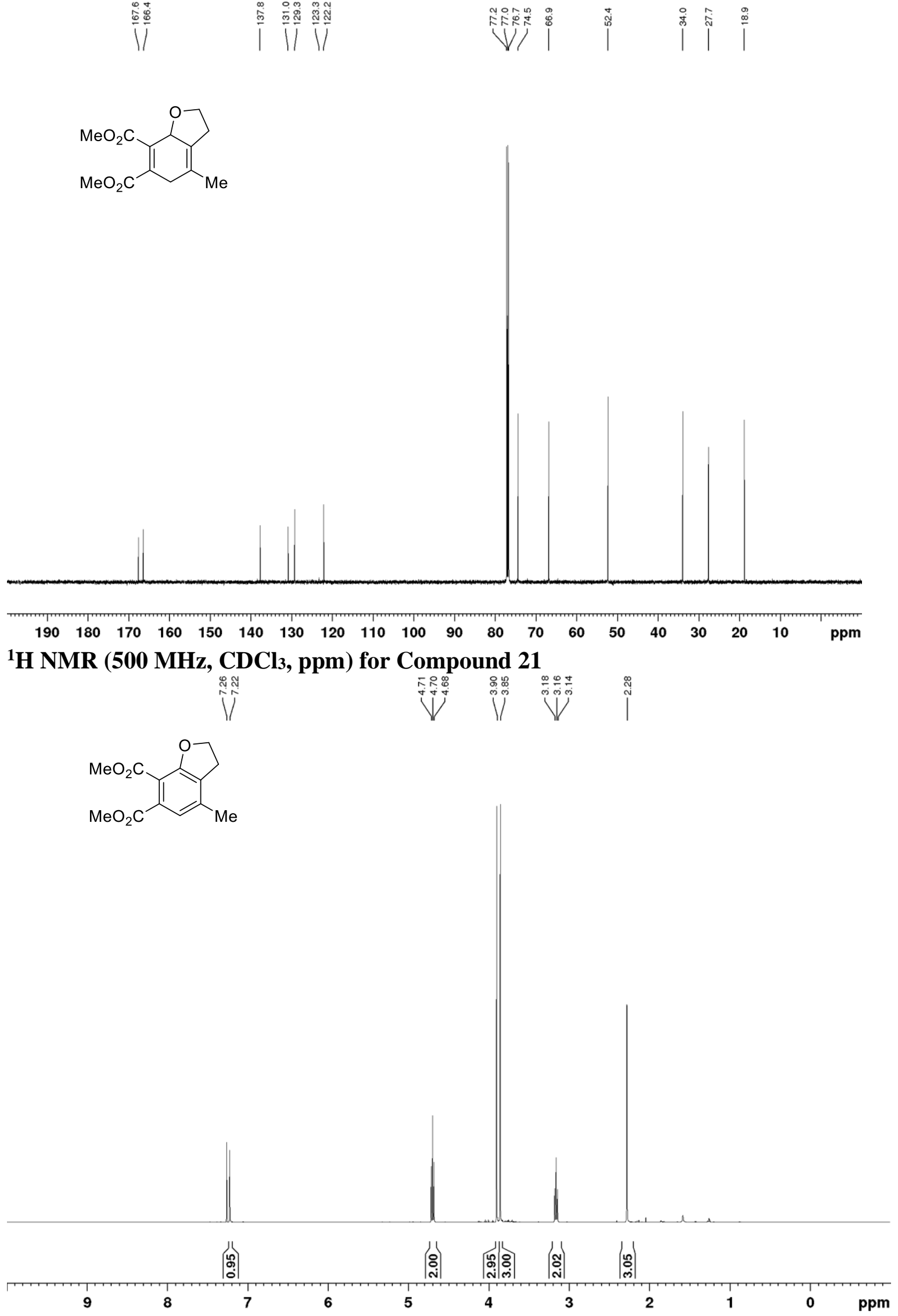

S-83 
${ }^{13} \mathrm{C}$ NMR (126 MHz, CDCl3, ppm) for Compound 21

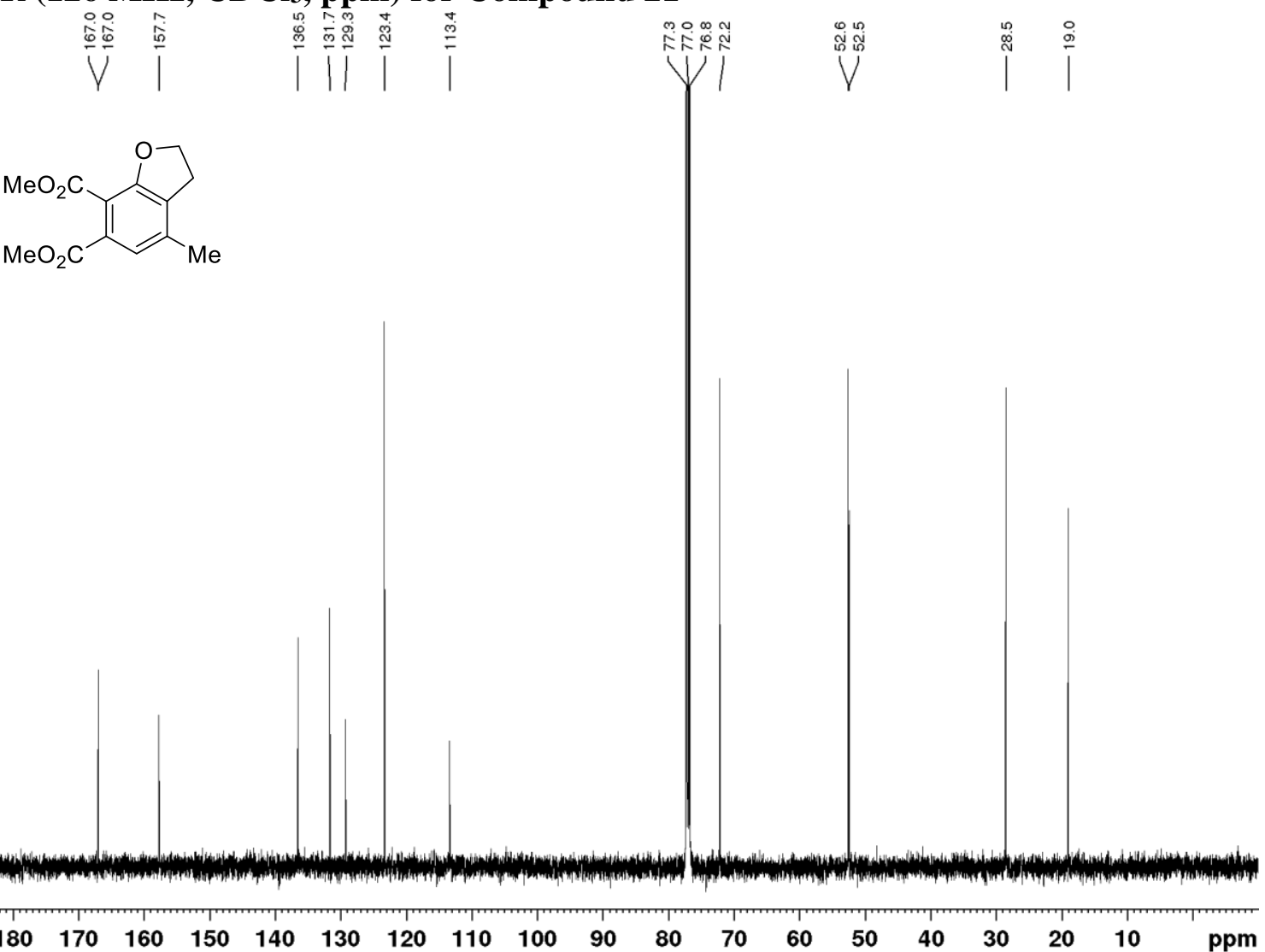

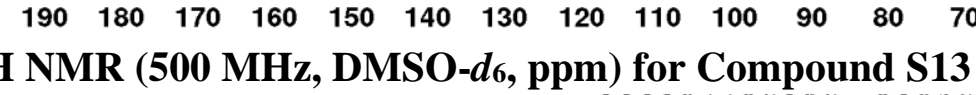

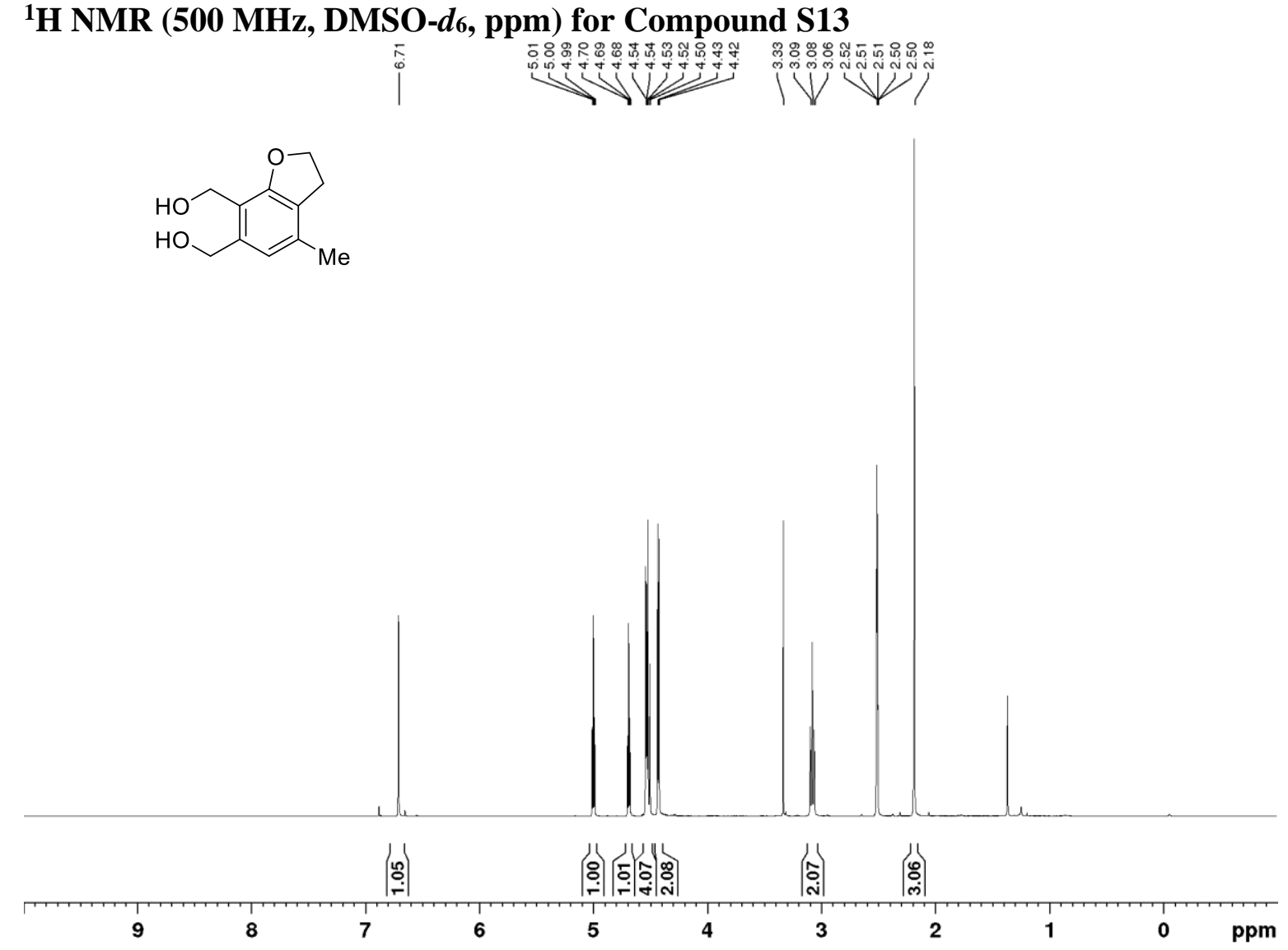


${ }^{13}$ C NMR (126 MHz, DMSO-d6, ppm) for Compound S13

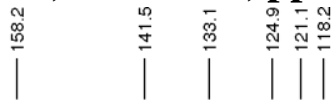<smiles>C[N+](=O)c1cc(CO)c(CO)c2c1CCO2</smiles>

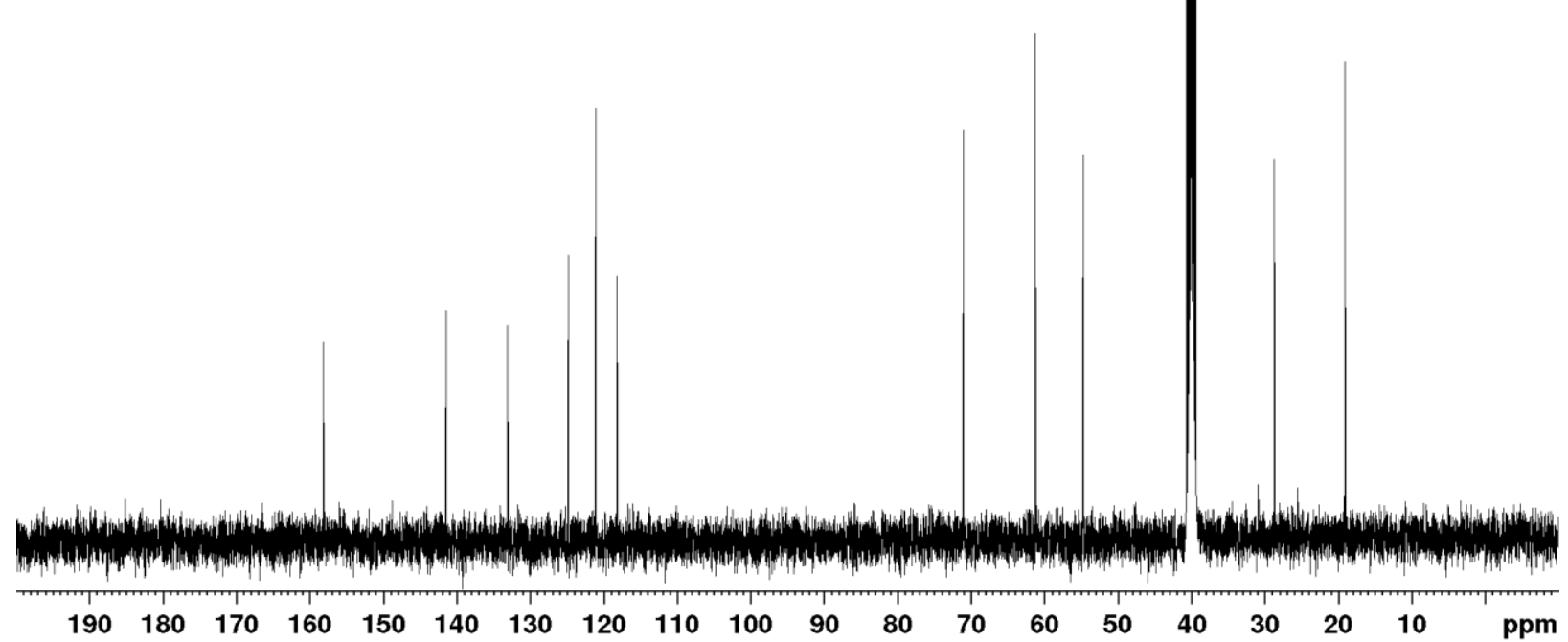
${ }^{1} \mathrm{H}$ NMR (500 MHz, CDCl3, ppm) for Compound S13<smiles>O=[W]c1cc(CO)c(CO)c2c1CCO2</smiles>

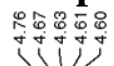

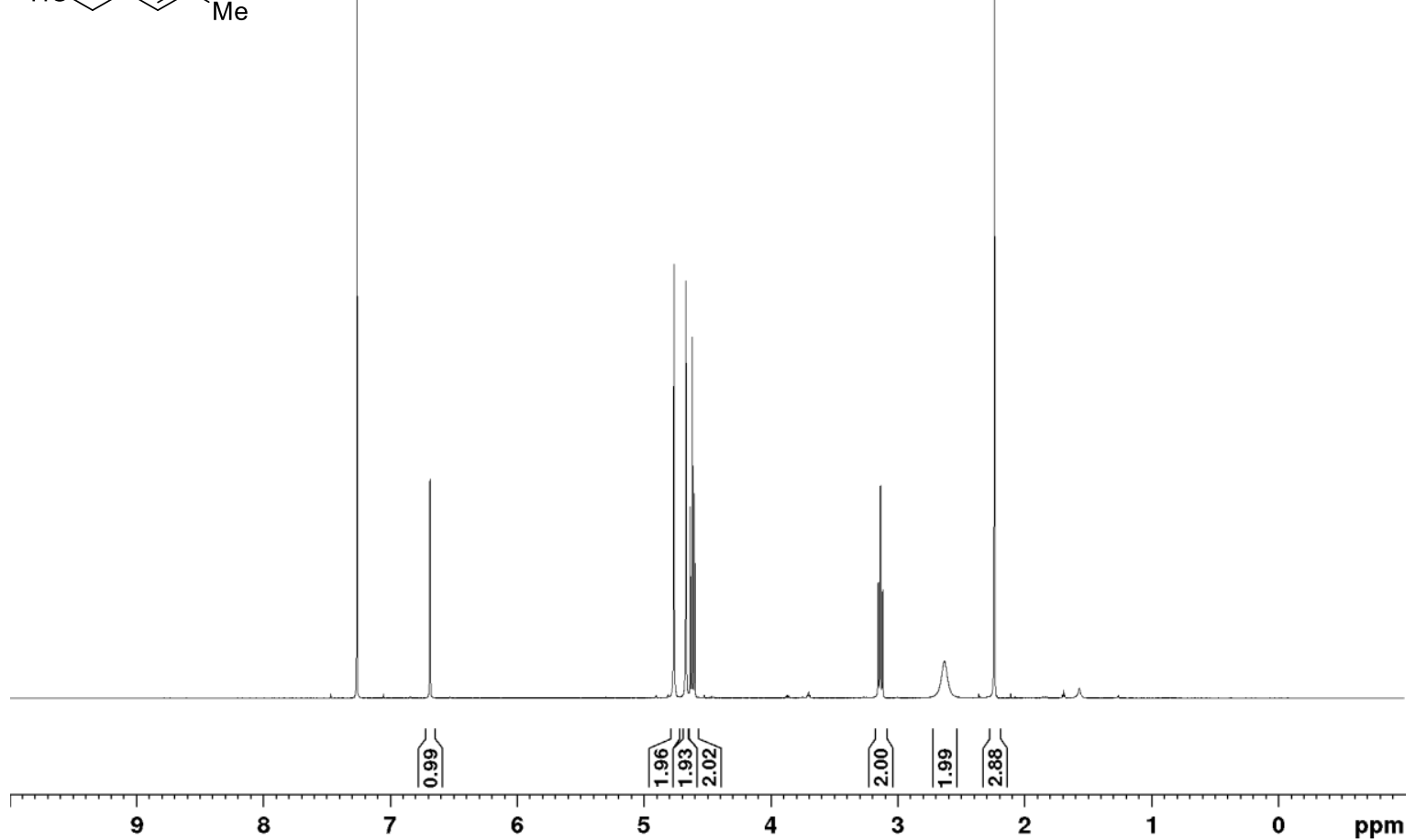




\section{${ }^{13} \mathrm{C}$ NMR (126 MHz, $\mathrm{CDCl}_{3}$, ppm) for Compound $\mathrm{S13}$}

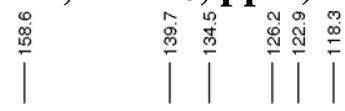<smiles>O=[SH]c1cc(CO)c(CO)c2c1CCO2</smiles>
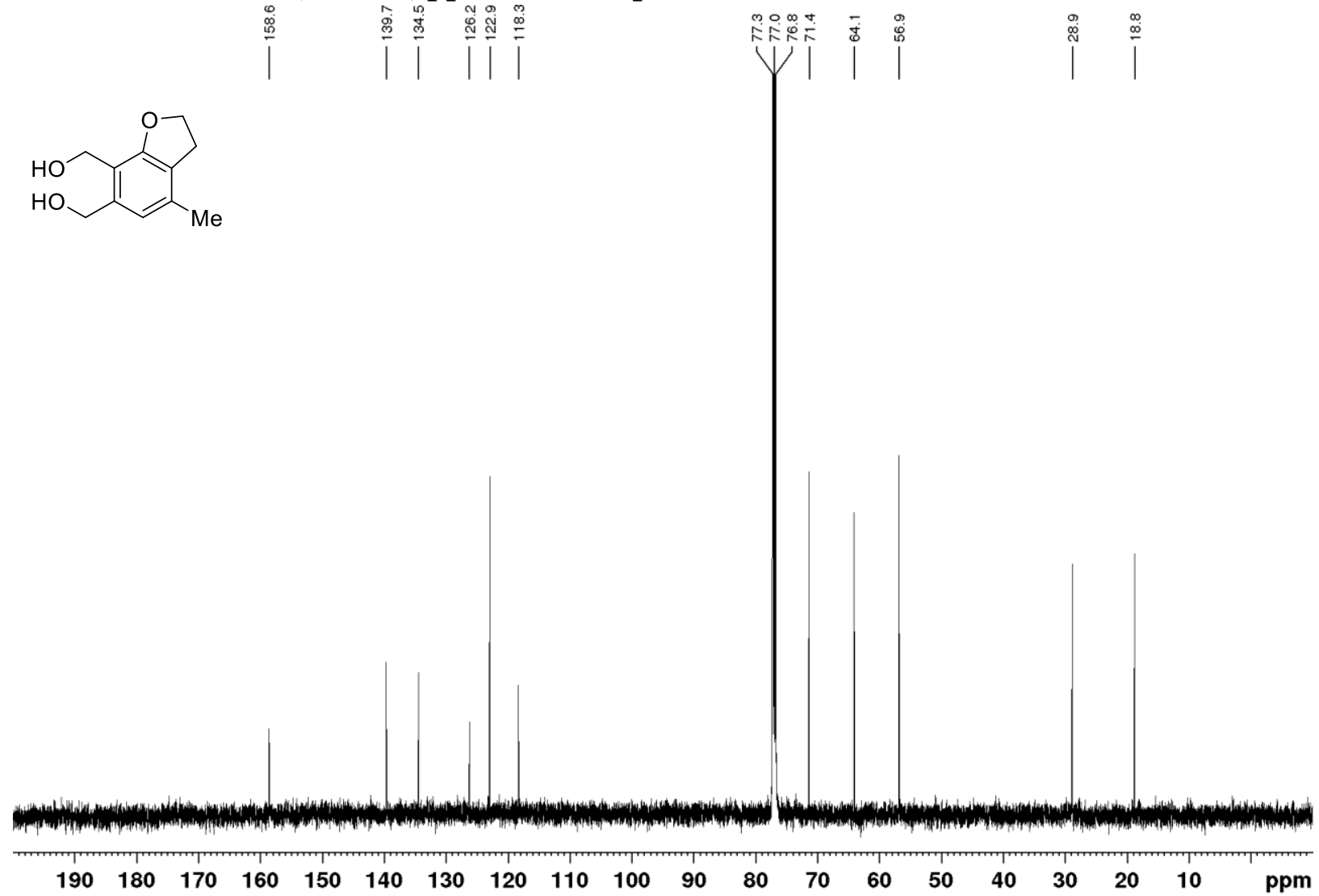

${ }^{1} \mathrm{H}$ NMR (500 MHz, $\mathrm{CDCl}_{3}, \mathrm{ppm}$ ) for Compound 8
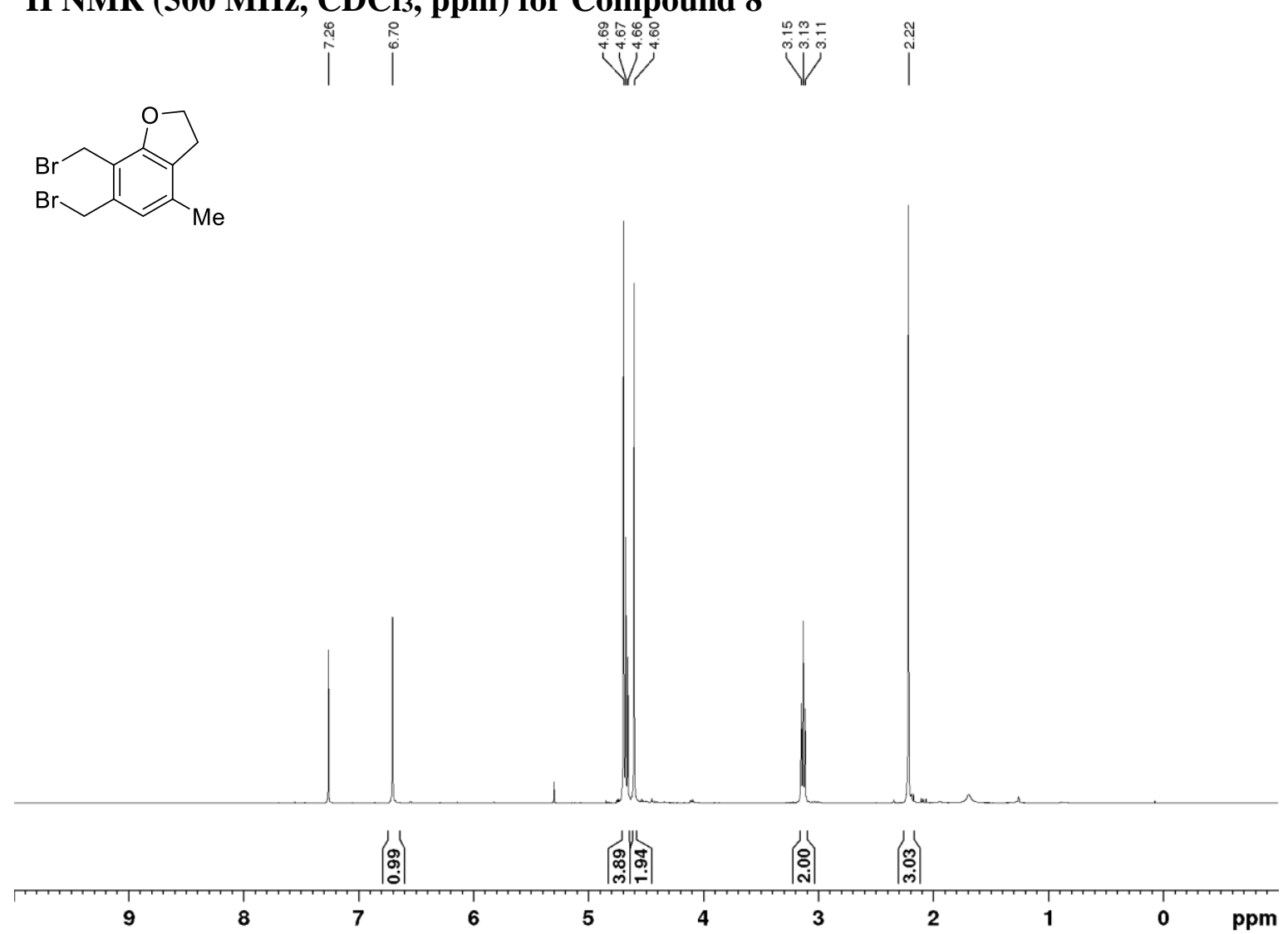
${ }^{13} \mathrm{C}$ NMR (126 MHz, $\left.\mathrm{CDCl}_{3}, \mathrm{ppm}\right)$ for Compound 8

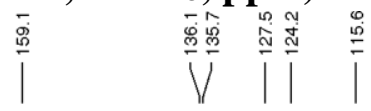<smiles>Cc1cc(CBr)c(CBr)c2c1CCO2</smiles>
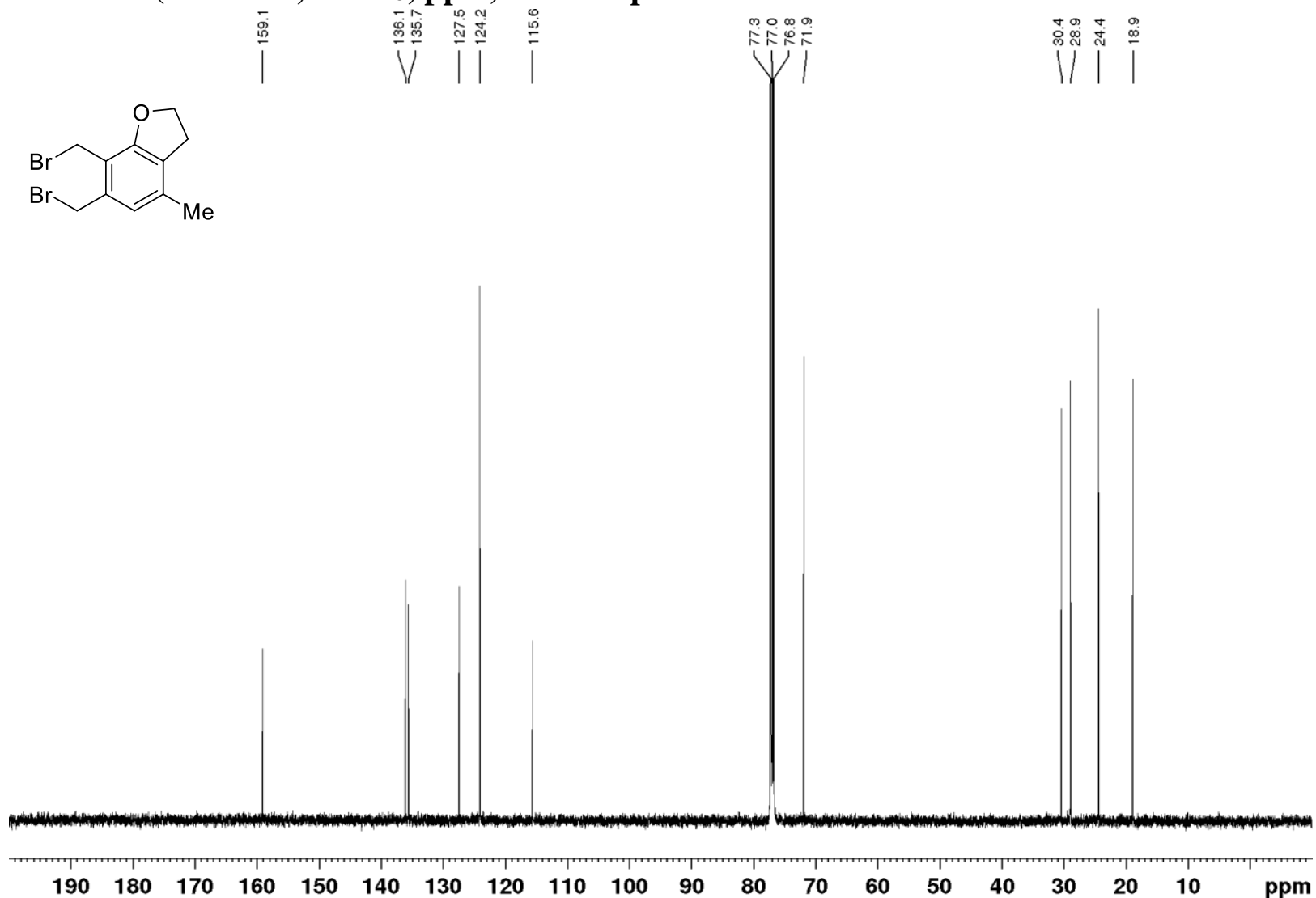

${ }^{1} \mathrm{H}$ NMR (500 MHz, $\mathrm{CDCl}_{3}$, ppm) for Compound 7

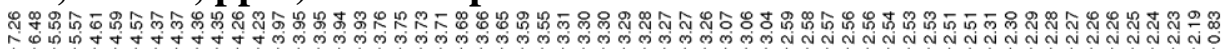<smiles>Cc1cc2c(c3c1CCO3)C[C@@]1(C2)SCC[C@@H]2OC[C@@H](C(C)C)N2C1=O</smiles>

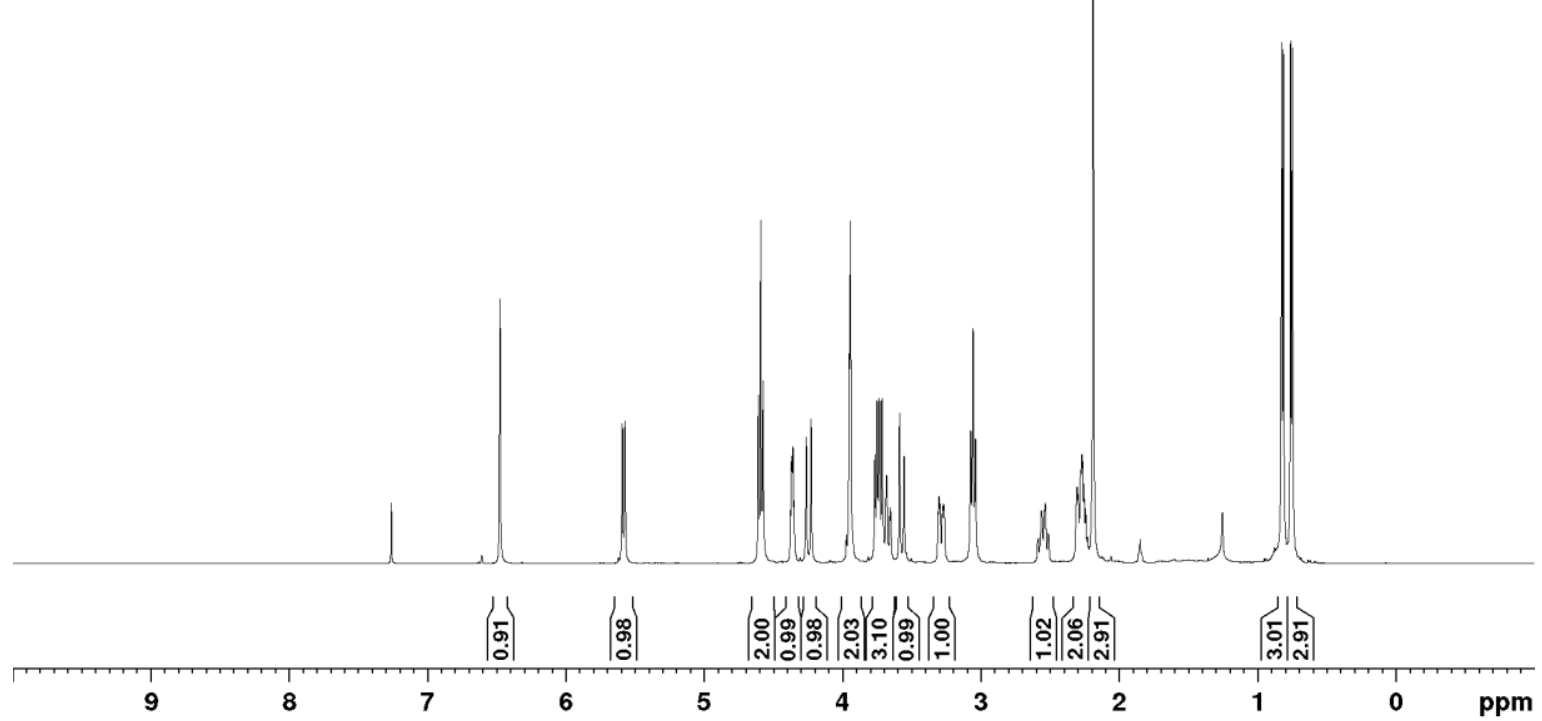


${ }^{13} \mathrm{C}$ NMR (126 MHz, $\mathrm{CDCl}_{3}$, ppm) for Compound 7
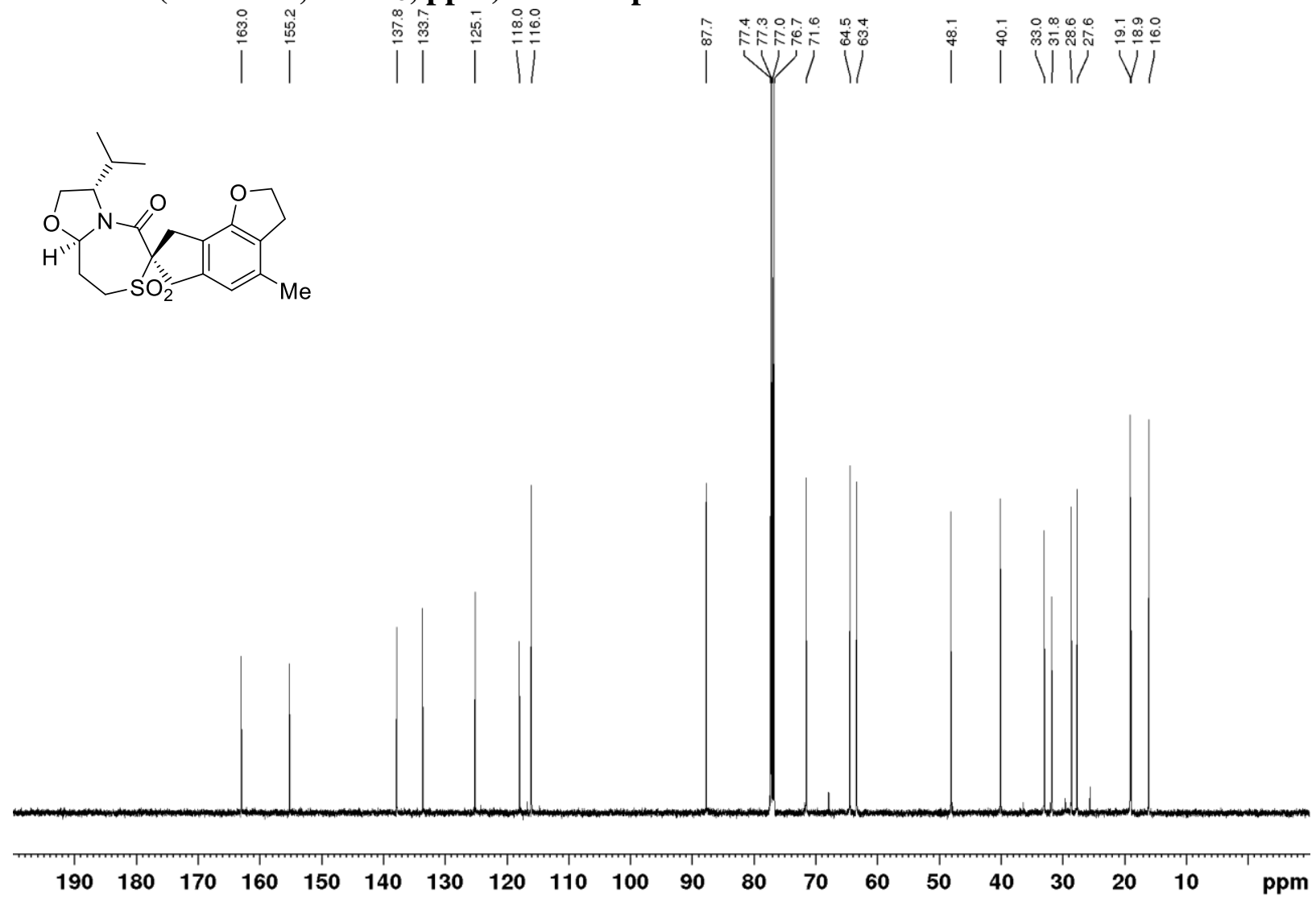

HSQC (126 MHz, $\mathrm{CDCl}_{3}$, ppm) for Compound 7

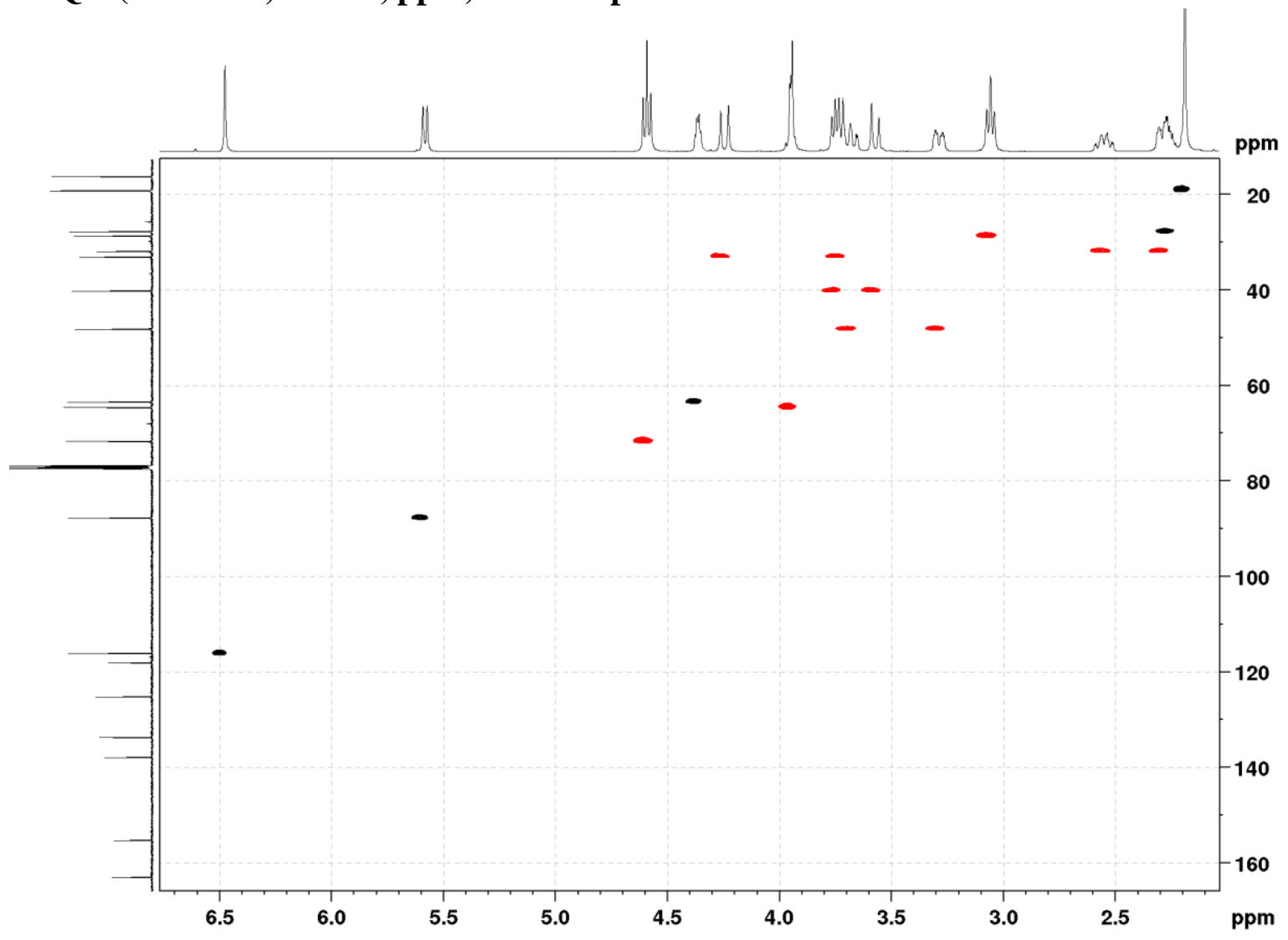

S-88 
NOESY (126 MHz, CDCl3, ppm) for Compound 7

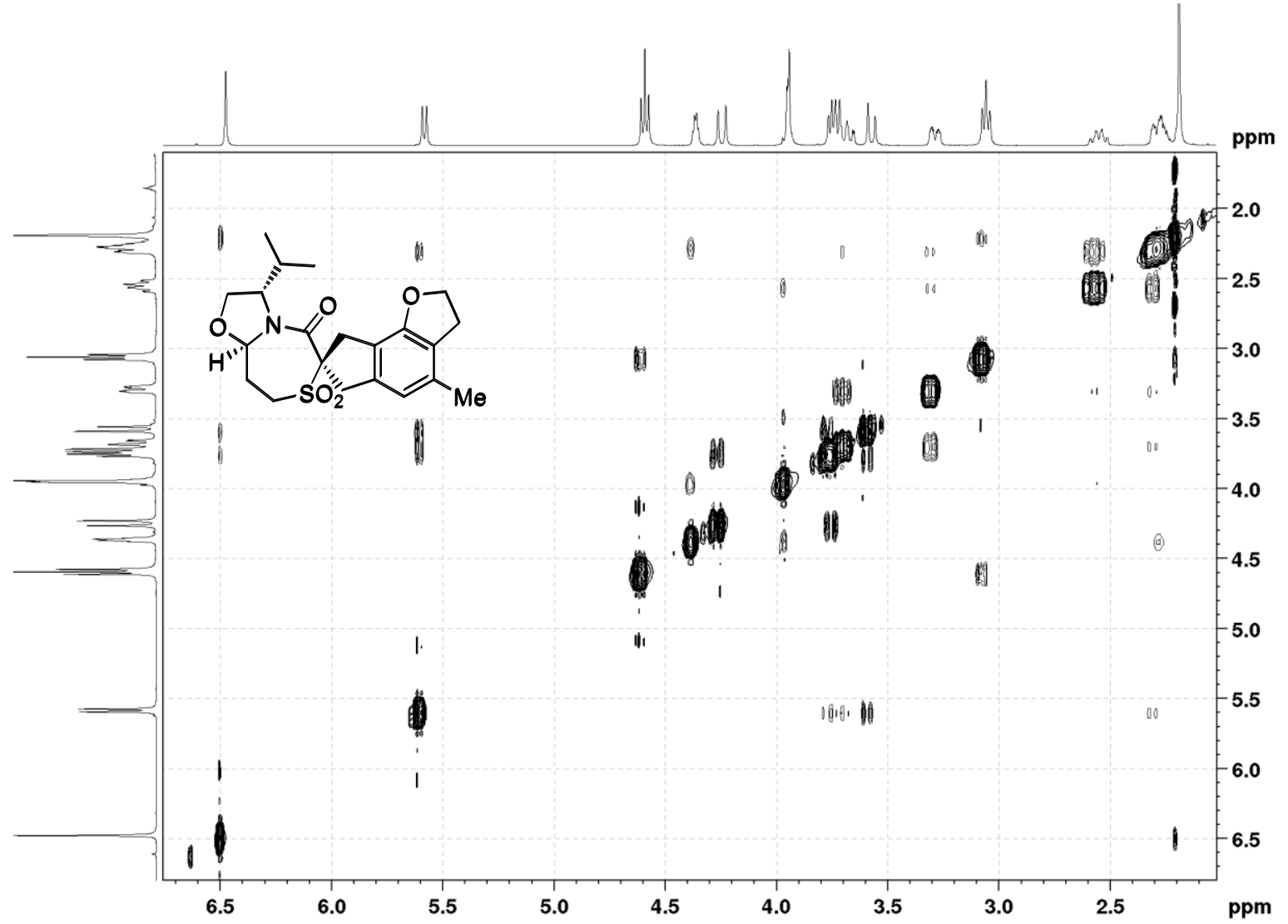

${ }^{1} \mathrm{H}$ NMR (500 MHz, $\left.\mathrm{CDCl}_{3}, \mathrm{ppm}\right)$ for Compound 22

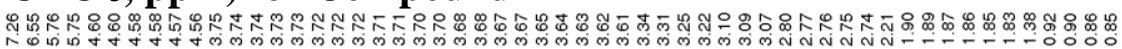<smiles>[CH][N+](=O)c1cc2c(c3c1OCCO3)C[C@@H](C(=O)N[C@H](CO)C(C)C)C2</smiles>

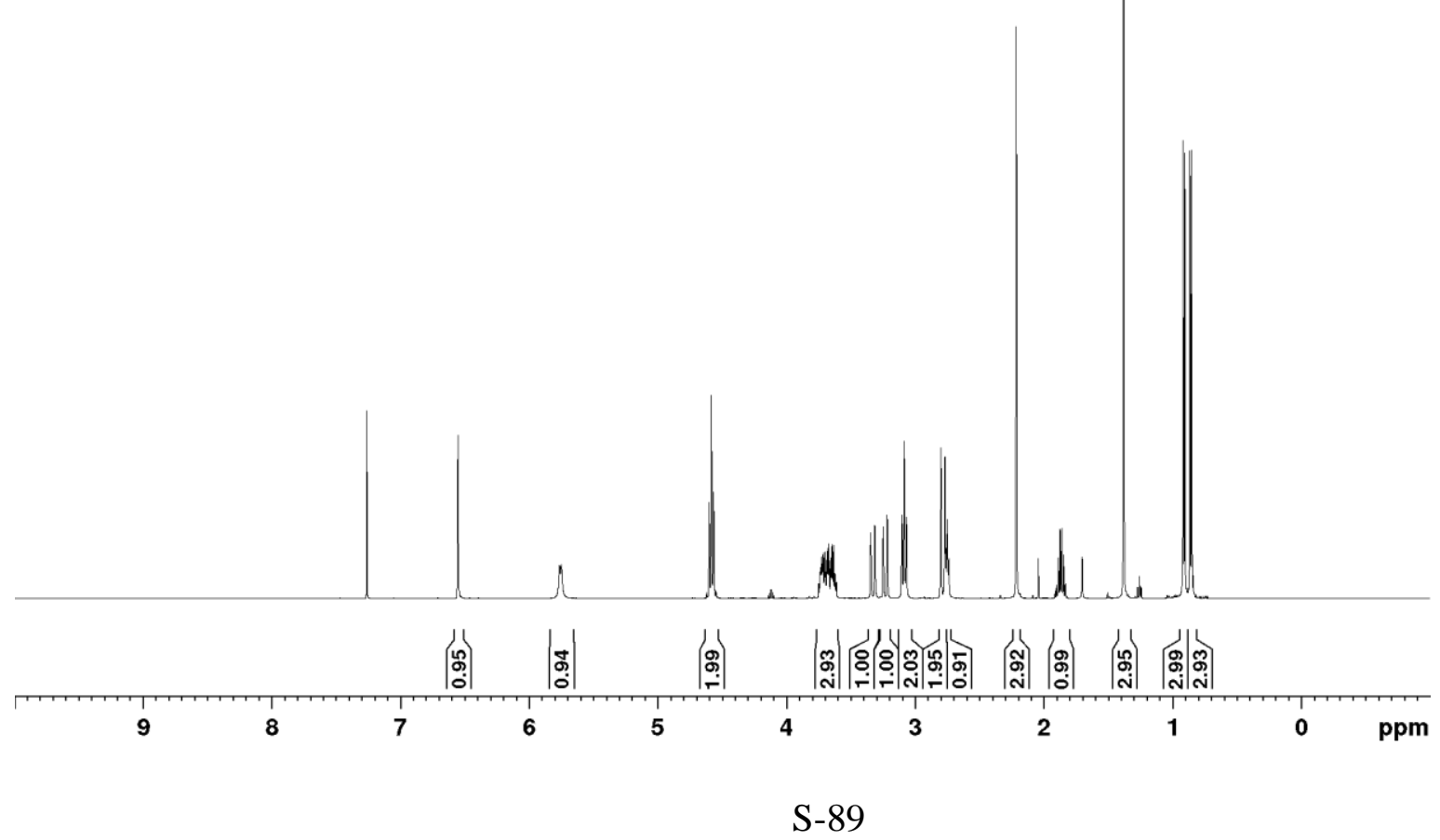


${ }^{13} \mathrm{C}$ NMR (126 MHz, CDCl3, ppm) for Compound 22

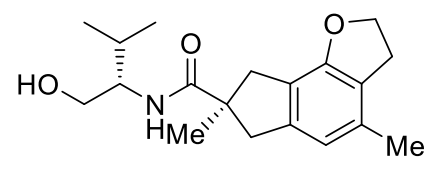

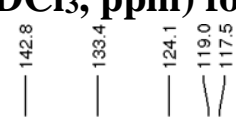

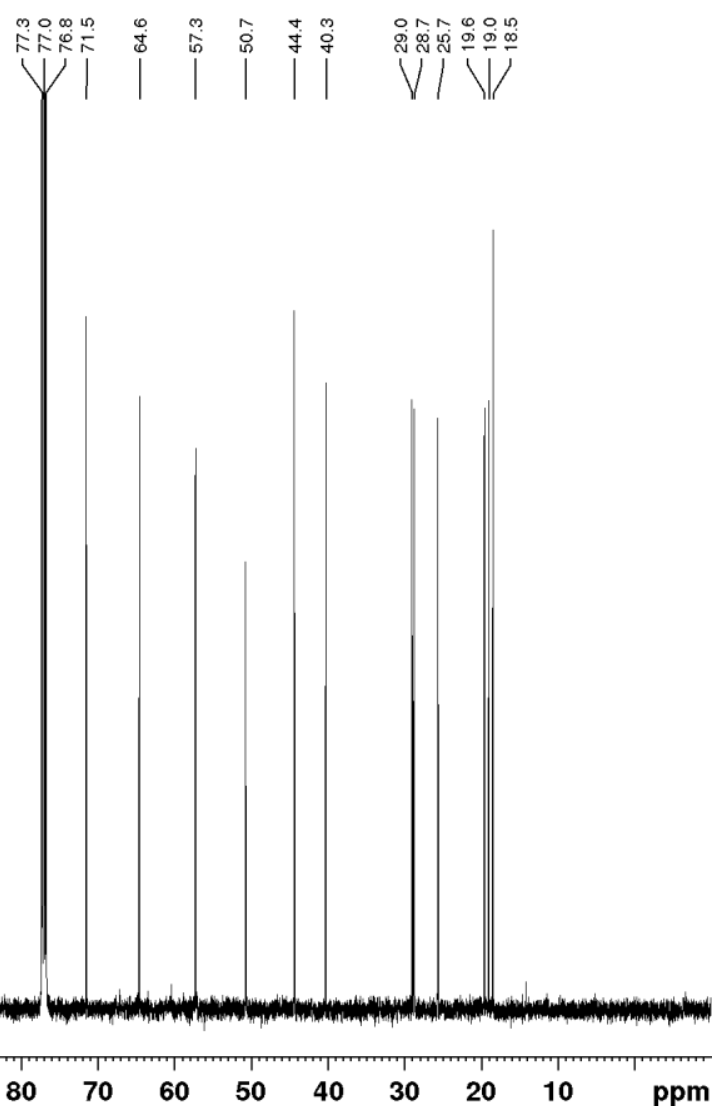

$\begin{array}{llllllllllll}190 & 180 & 170 & 160 & 150 & 140 & 130 & 120 & 110 & 100 & 90 & 80\end{array}$

${ }^{1} \mathrm{H}$ NMR (500 MHz, CDCl3, ppm) for Compound 23
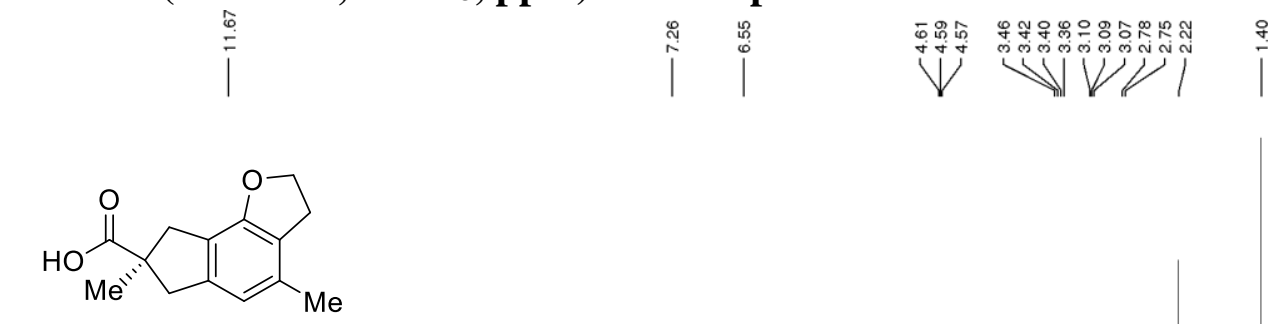

$\left.\right|^{-\frac{10}{10}}$

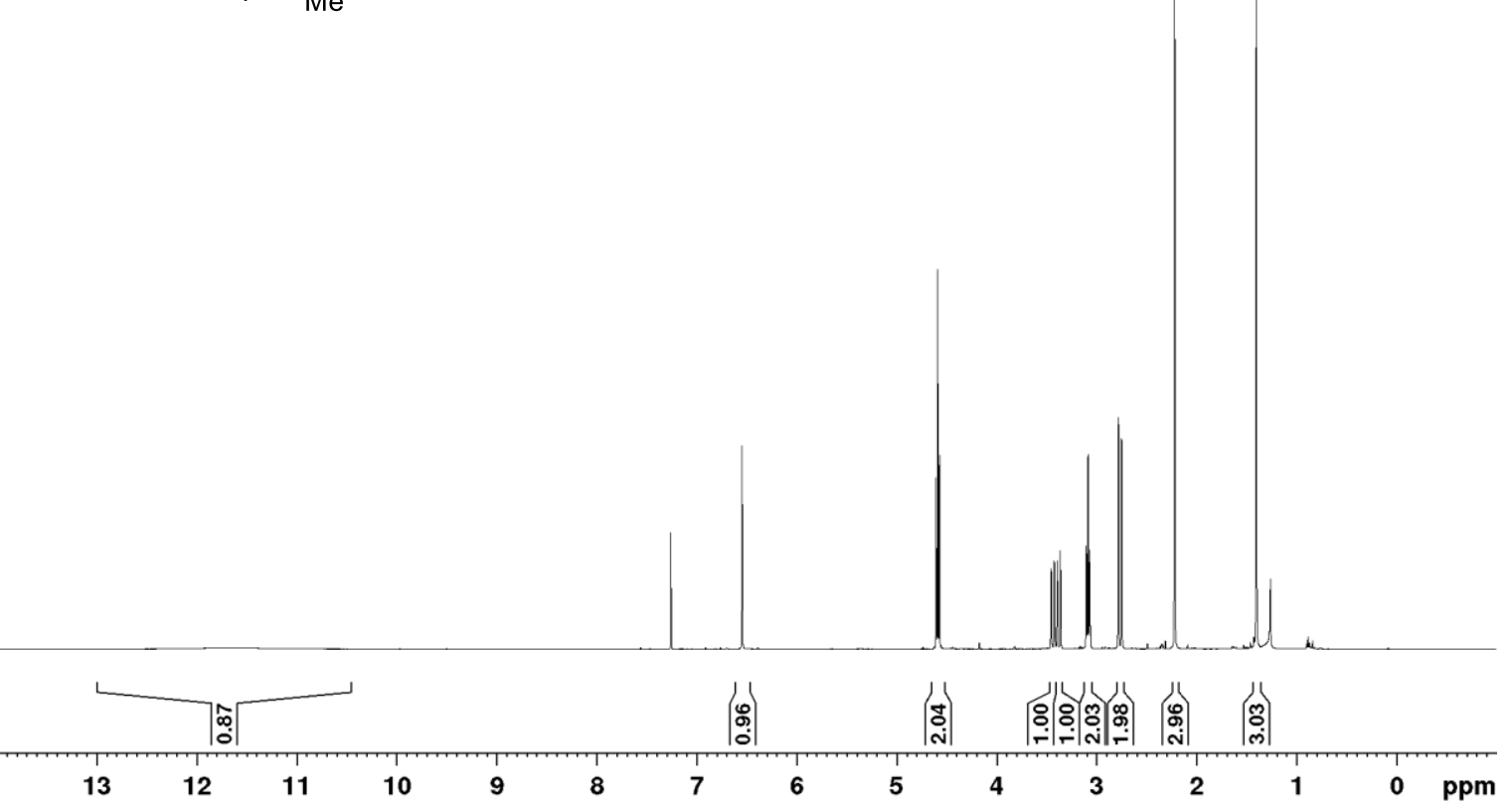

S-90 
${ }^{13} \mathrm{C}$ NMR (126 MHz, $\left.\mathrm{CDCl}_{3}, \mathrm{ppm}\right)$ for Compound 23

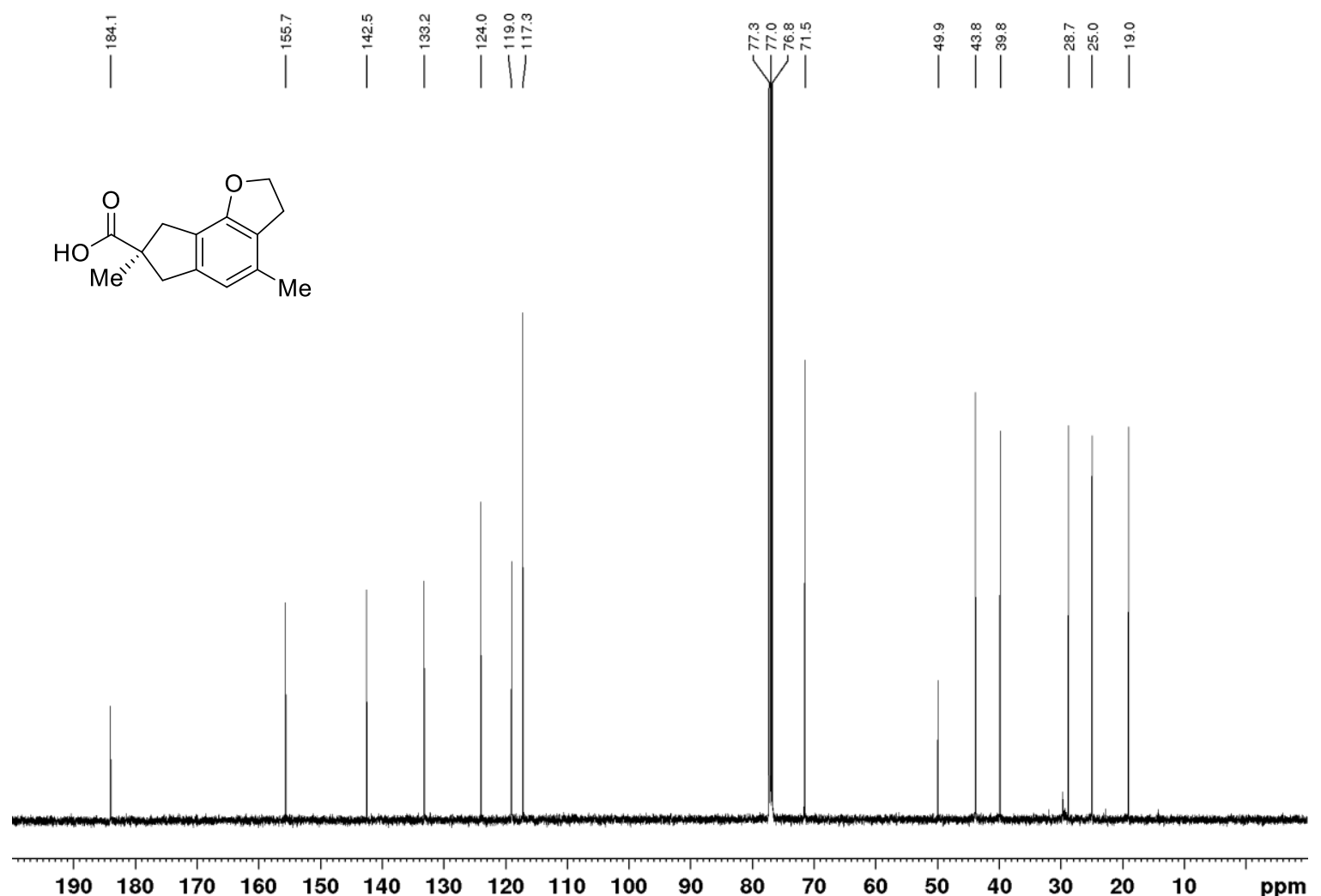

${ }^{1} \mathrm{H}$ NMR (500 MHz, CDCl3, ppm) for Compound $1((R)$-puraquinonic acid)<smiles>C[C@H](O)C(=O)OCCCO</smiles>

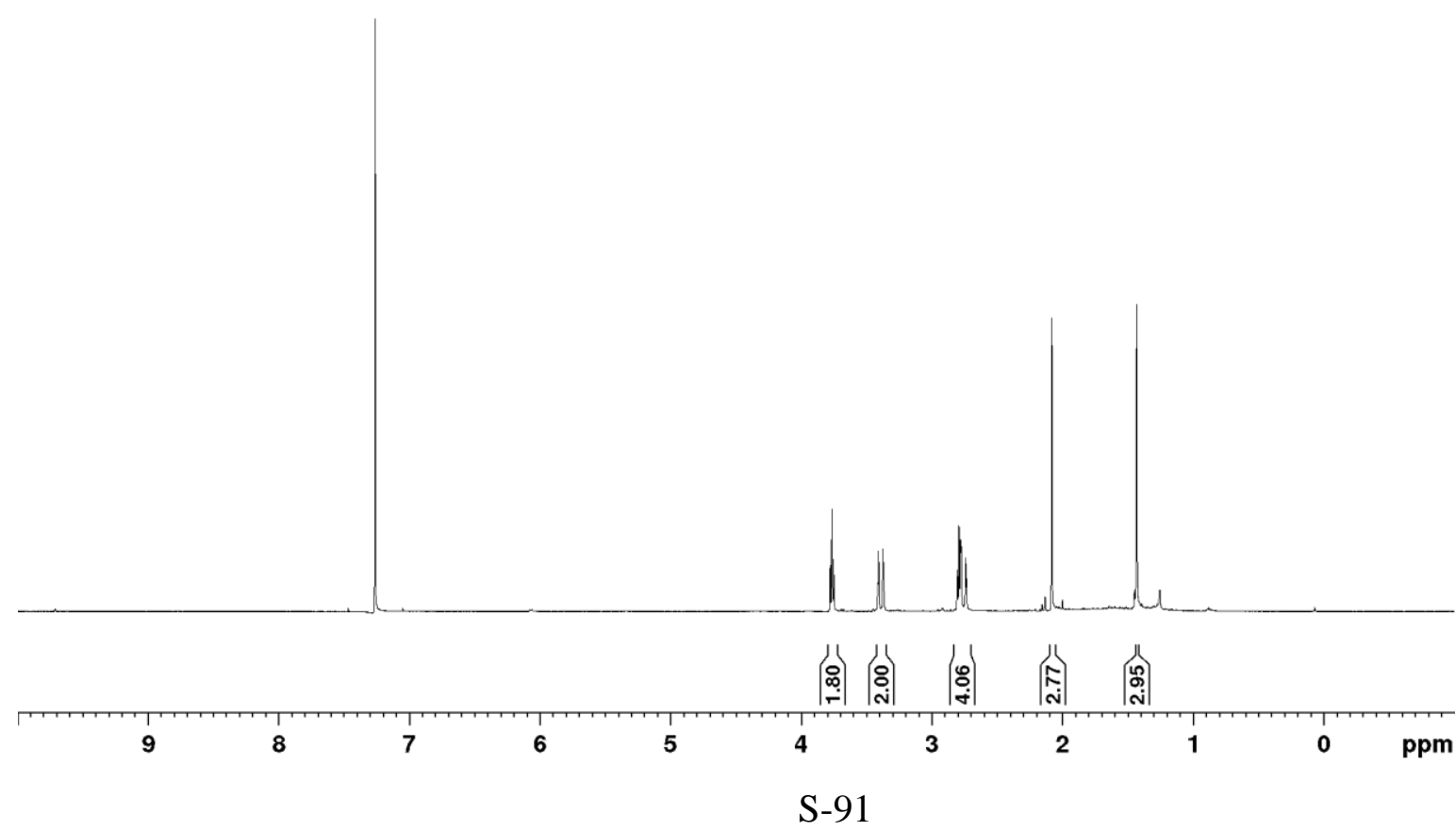


${ }^{13} \mathrm{C}$ NMR (101 MHz, $\left.\mathrm{CDCl}_{3}, \mathrm{ppm}\right)$ for Compound $1((R)$-puraquinonic acid)

$\sqrt{V}$<smiles>CC1C(=O)C2=C(CC1C(=O)O)C(=O)C(CCO)C(=O)C2=O</smiles>

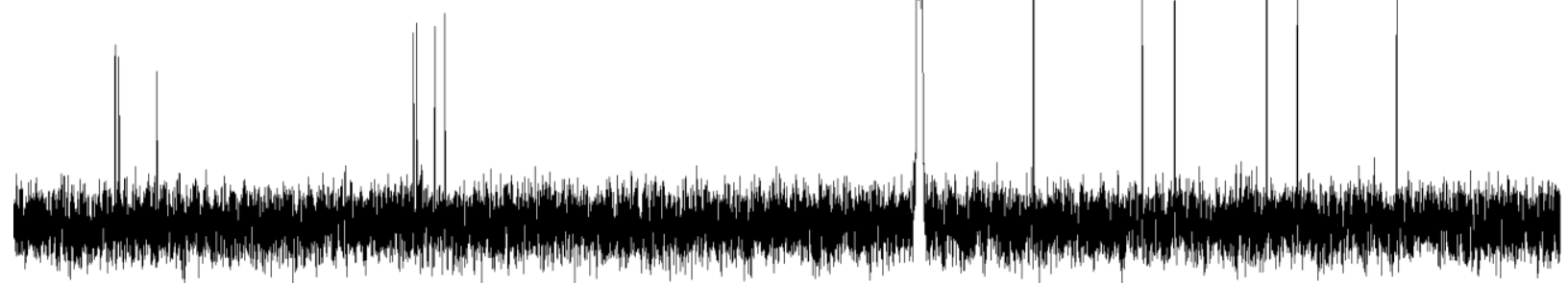

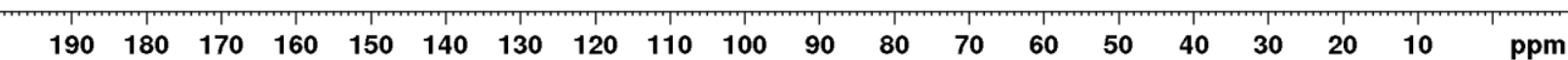
${ }^{1} \mathrm{H}$ NMR (500 MHz, DMSO- $\left.d_{6}, \mathrm{ppm}\right)$ for Compound S13

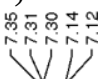

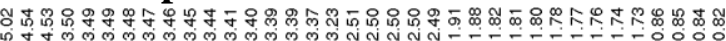
$\underbrace{2}_{1}$

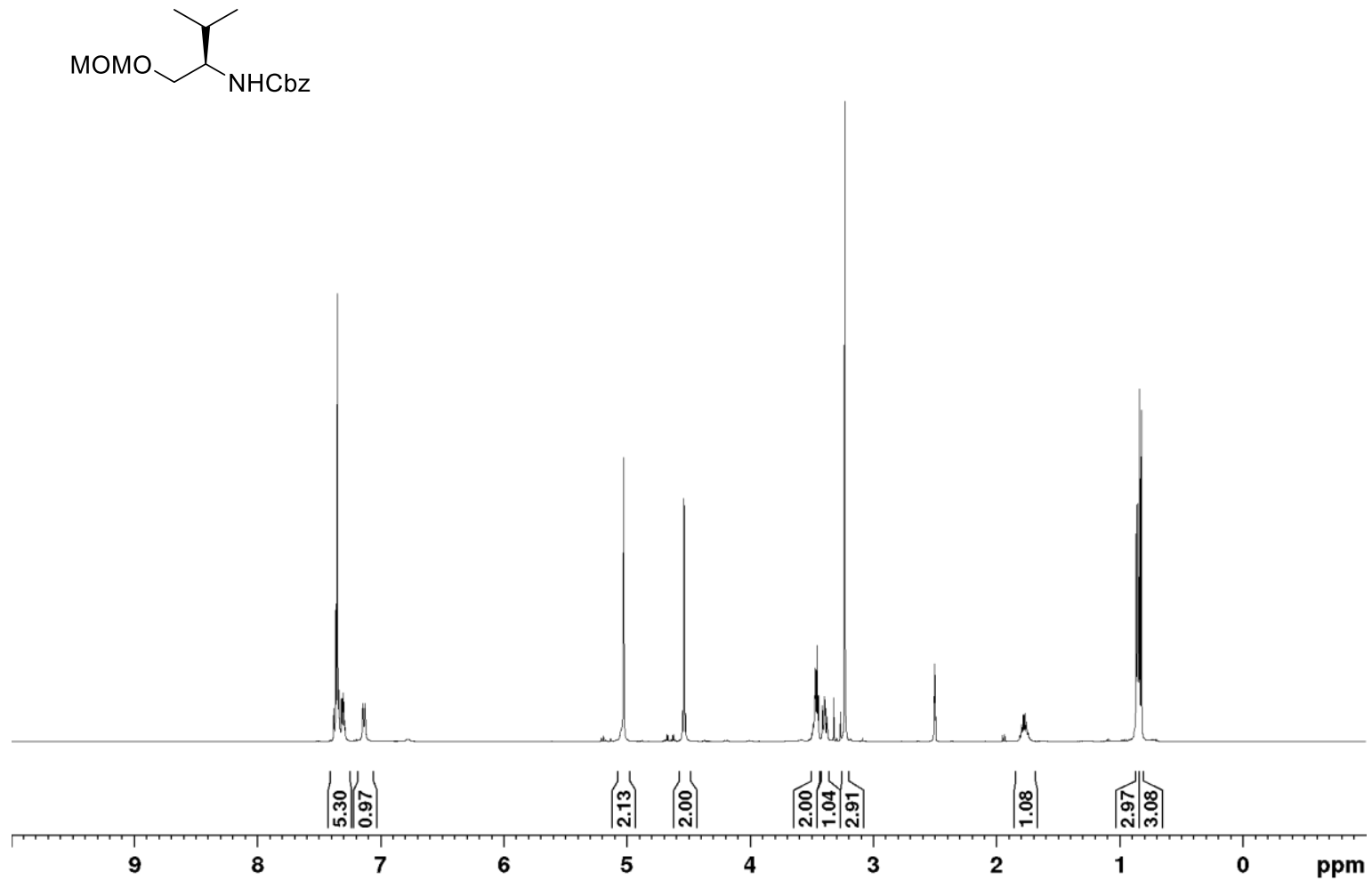


${ }^{13}$ C NMR (126 MHz, DMSO-d6, ppm) for Compound S13

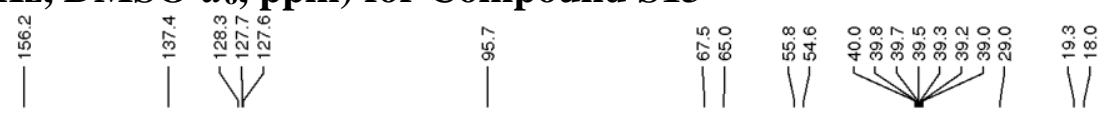<smiles>COCC(NC=[18O])C(C)C</smiles>

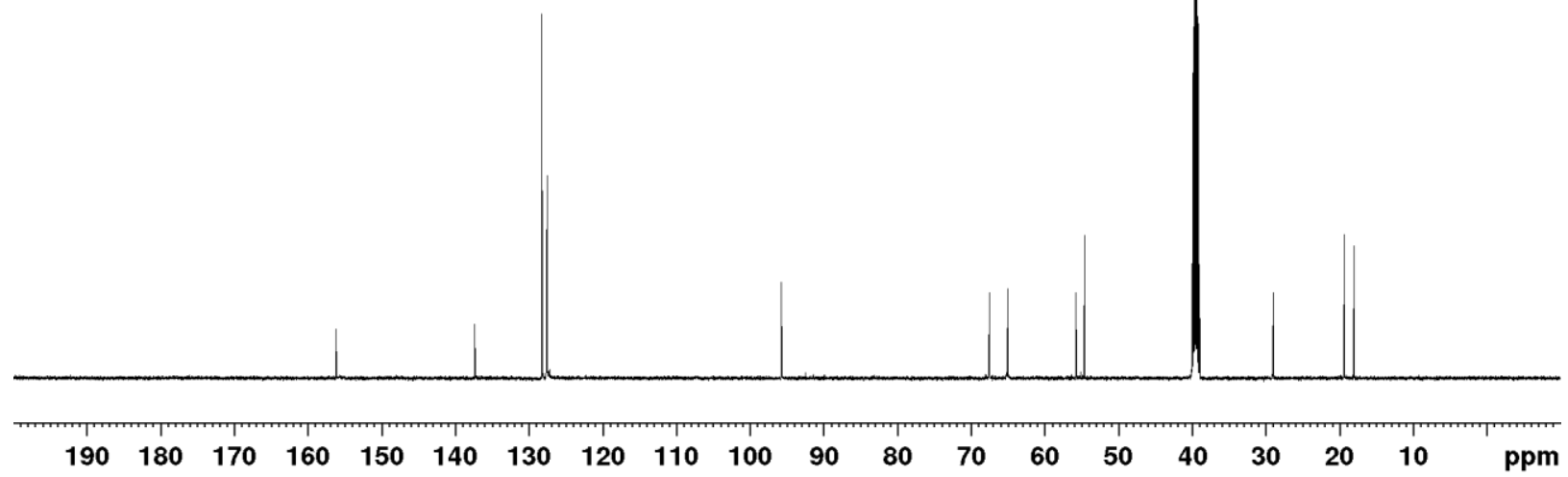
${ }^{1} \mathrm{H}$ NMR (500 MHz, CDCl3, ppm) for Compound S14

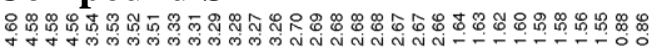

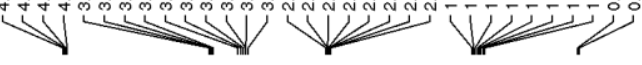<smiles>COCC(N)C(C)C</smiles>

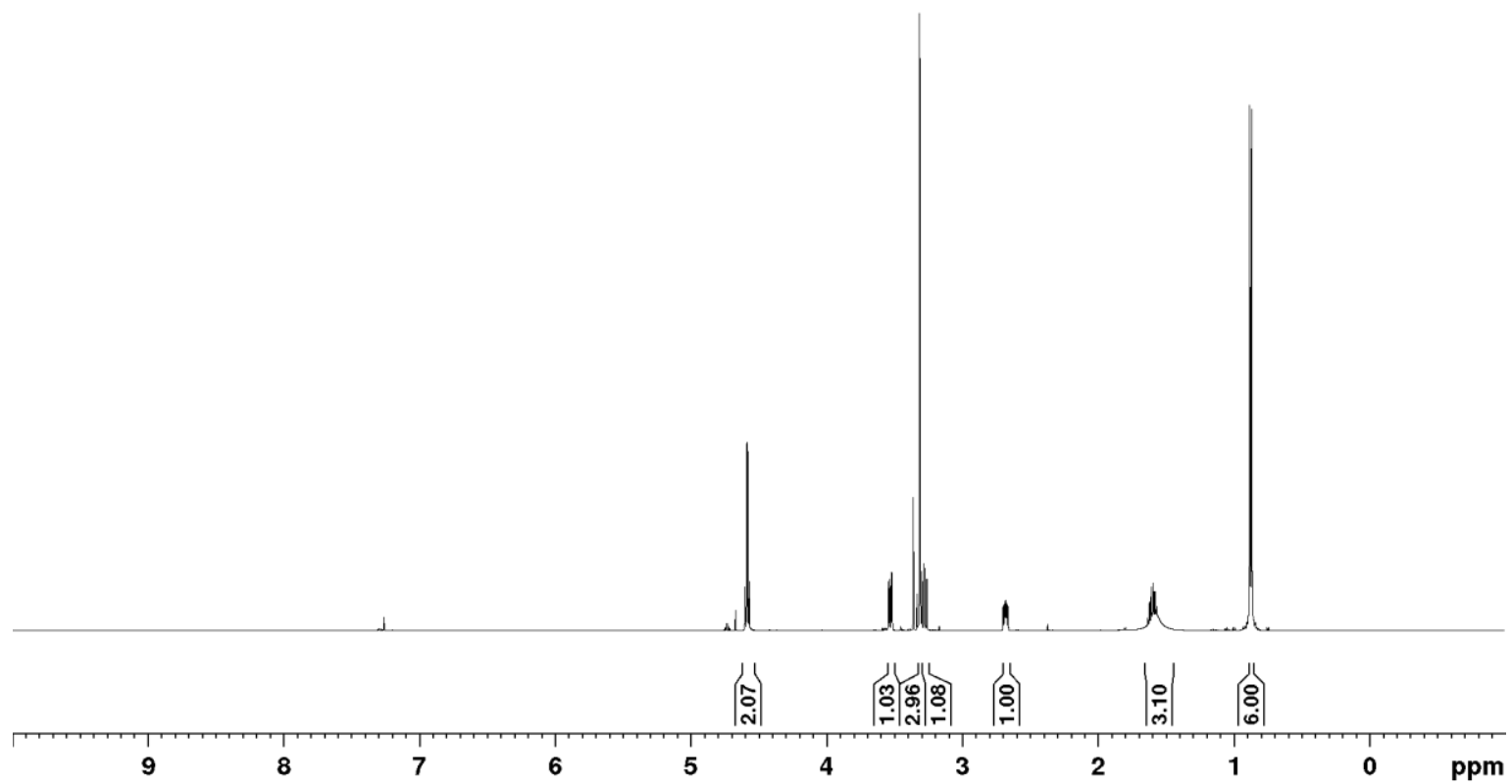

S-93 
${ }^{13} \mathrm{C}$ NMR (126 MHz, $\mathrm{CDCl}_{3}$, ppm) for Compound S14<smiles>COC[C@H](N)C(C)C</smiles>

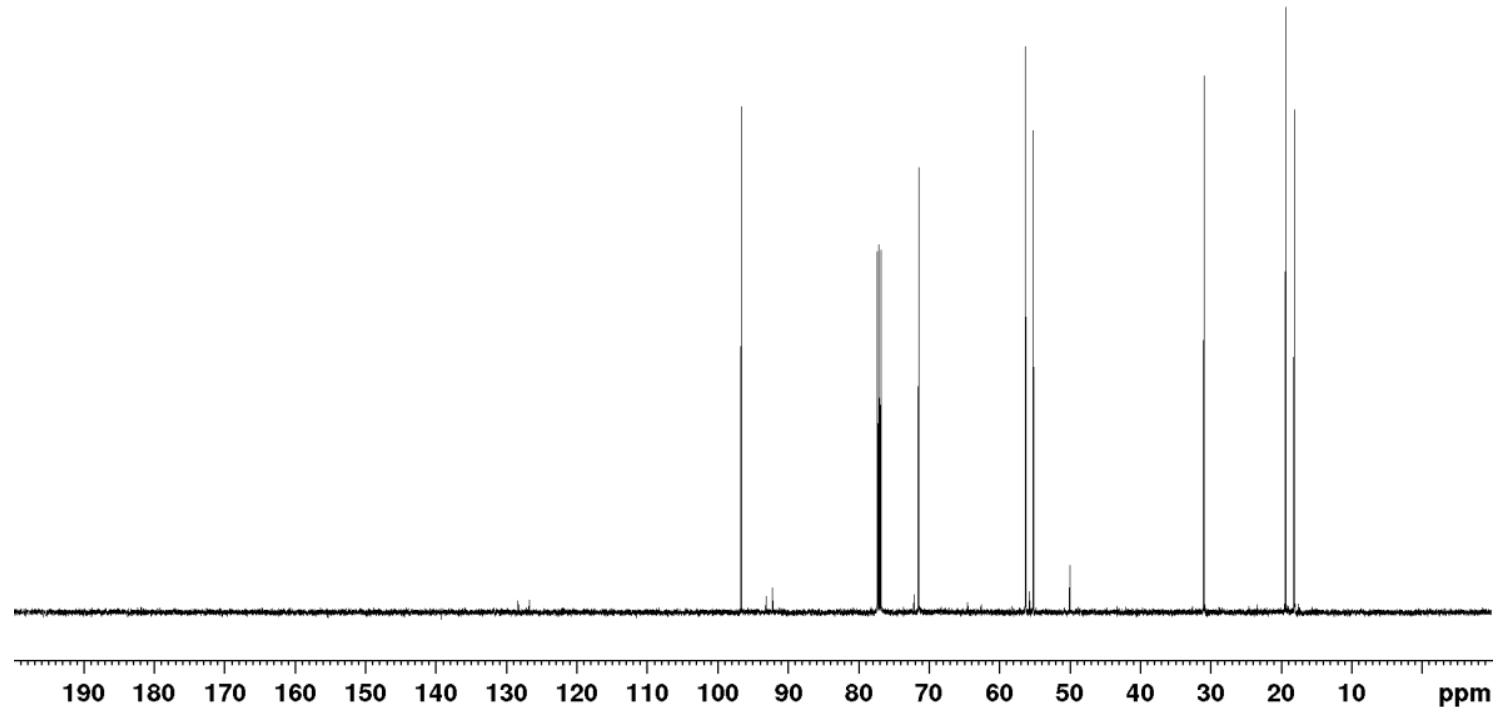

${ }^{1} \mathrm{H}$ NMR (500 MHz, $\mathrm{CDCl}_{3}, \mathrm{ppm}$ ) for Compound S15

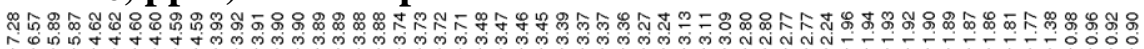<smiles>COC[C@H](NC(=O)[C@]1(C)Cc2cc(C)c3c(c2C1)OCC3)C(C)C</smiles>

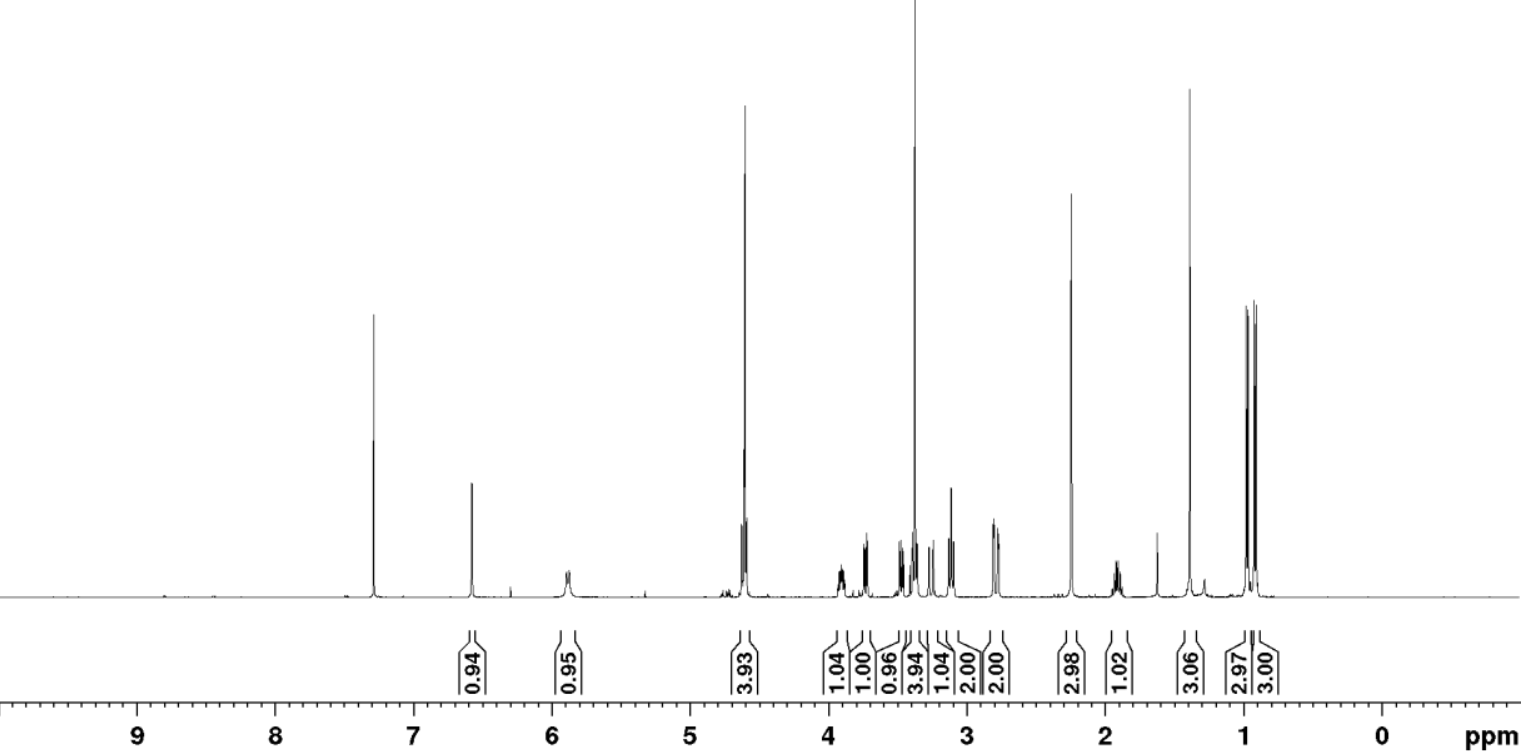




\section{${ }^{13} \mathrm{C}$ NMR (126 MHz, CDCl3, ppm) for Compound S15}
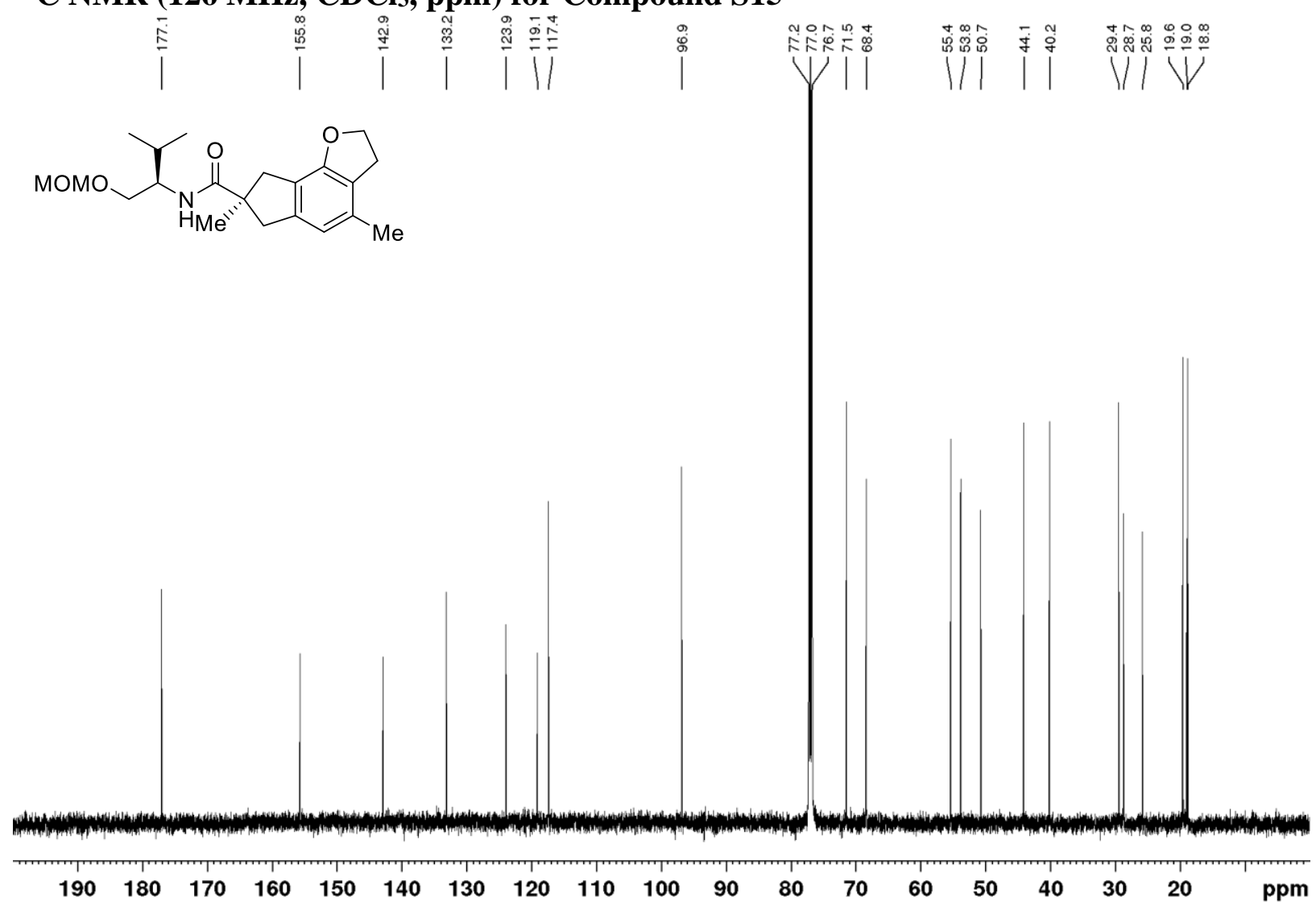

${ }^{1} \mathrm{H}$ NMR (500 MHz, CDCl3, ppm) for Compound S16

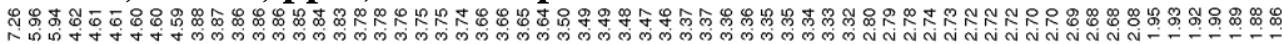

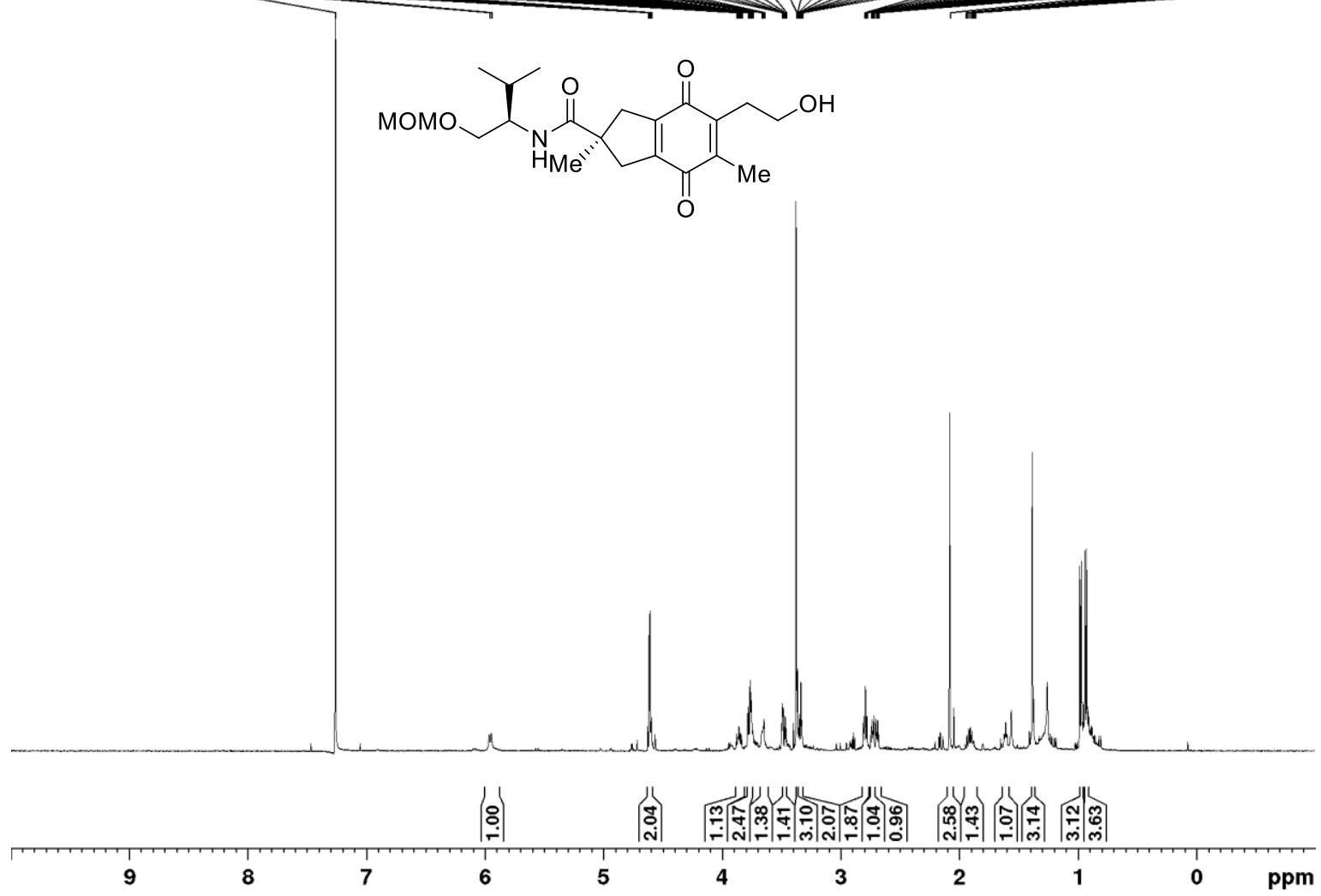

S-95 
${ }^{13} \mathrm{C}$ NMR (101 MHz, CDCl3, ppm) for Compound S16<smiles>COCC(NC(=O)[C@H]1CC2C(=O)C(CCO)=C(CCO)C(=O)C2CC1=O)C(C)C</smiles>
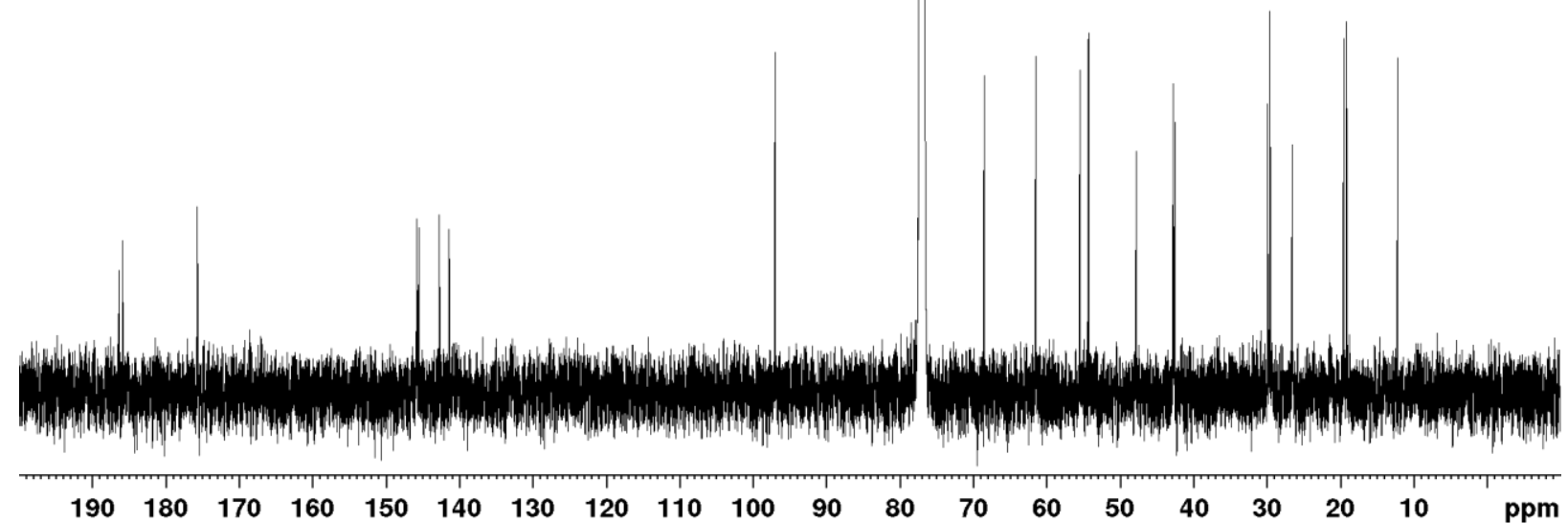

${ }^{1} \mathrm{H}$ NMR (500 MHz, $\mathrm{CDCl}_{3}, \mathrm{ppm}$ ) for Compound $\mathrm{S17}$
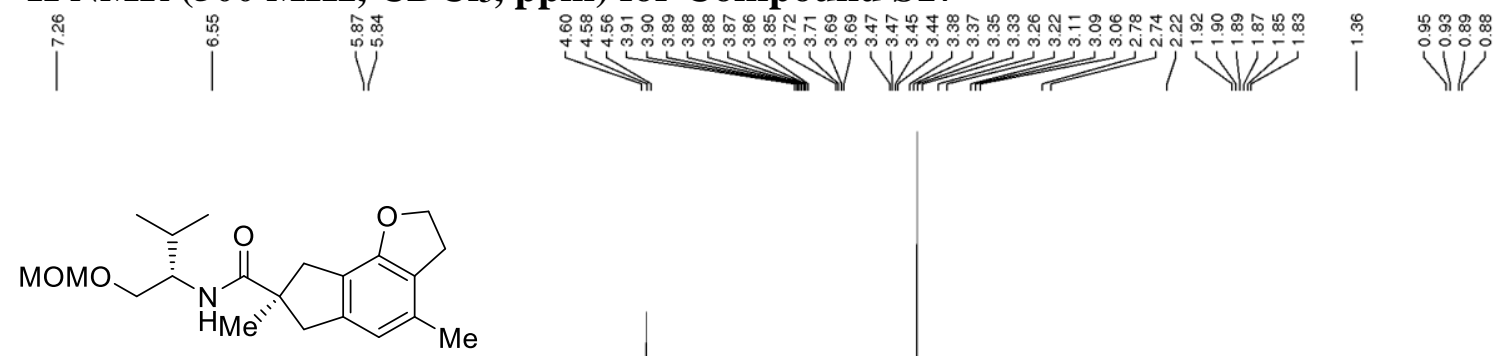

| | 
${ }^{13} \mathrm{C}$ NMR (126 MHz, $\mathrm{CDCl}_{3}$, ppm) for Compound $\mathrm{S17}$

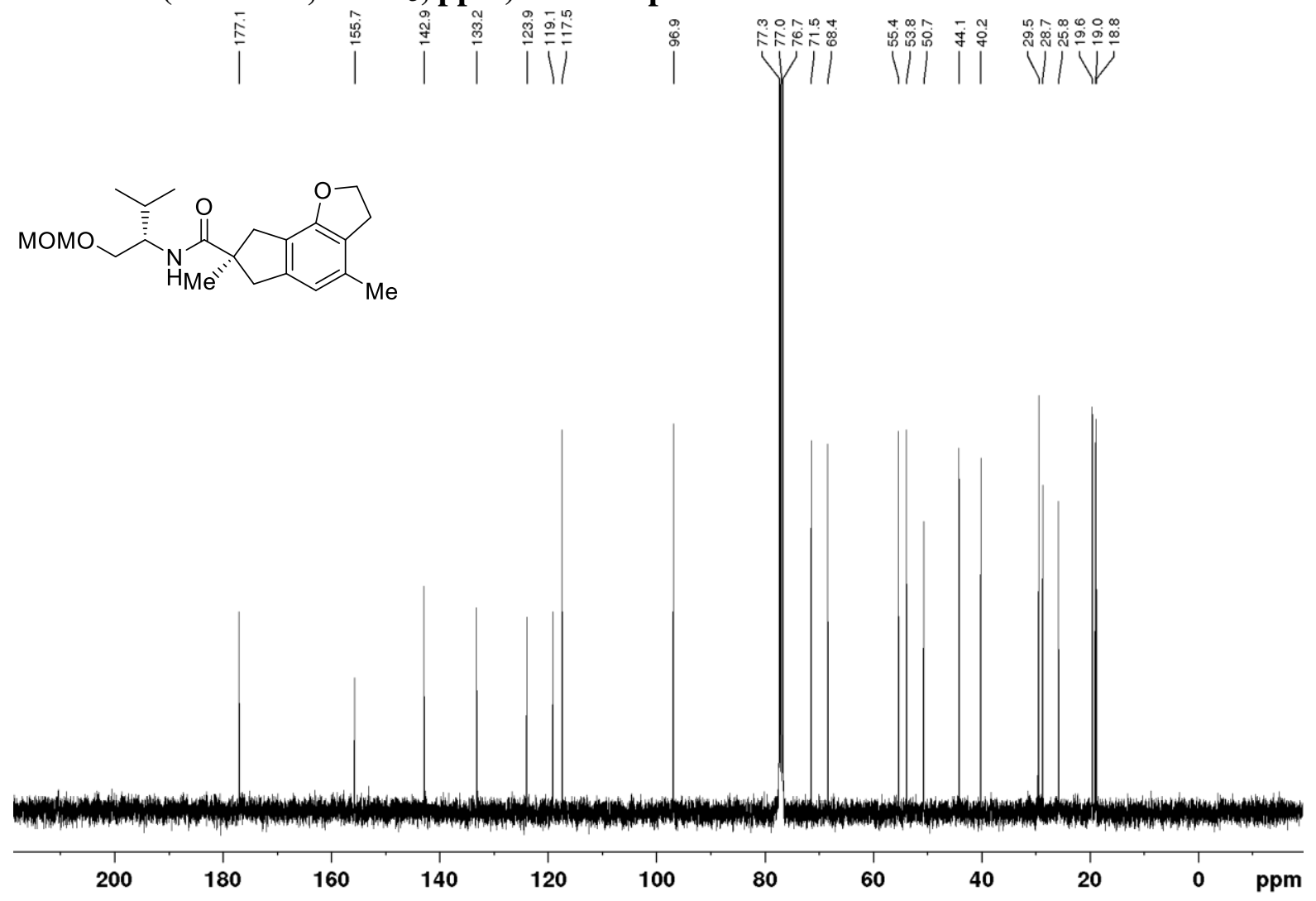

${ }^{1} \mathrm{H}$ NMR (500 MHz, $\left.\mathrm{CDCl}_{3}, \mathrm{ppm}\right)$ for Compound S18

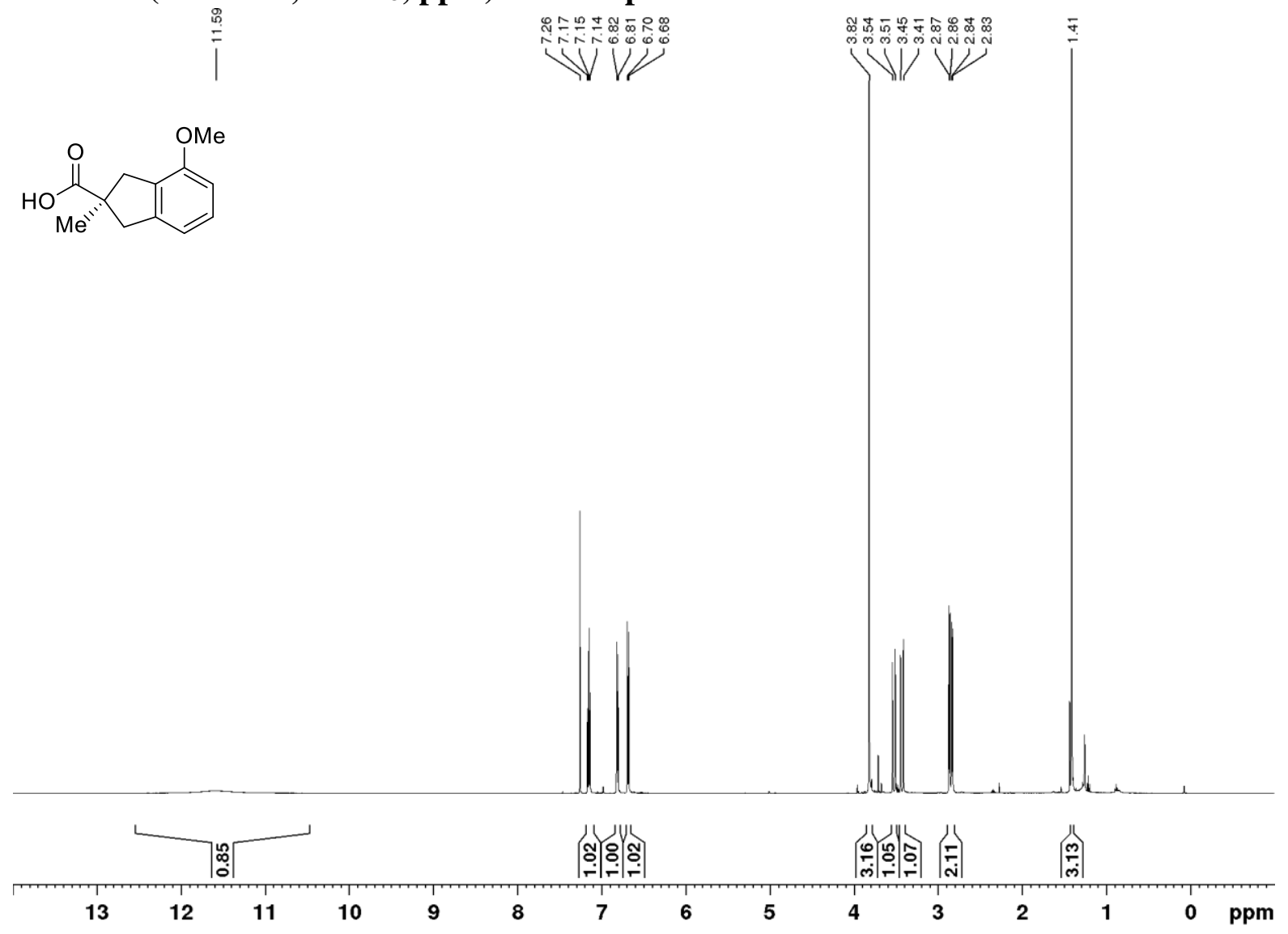


${ }^{13} \mathrm{C}$ NMR (126 MHz, $\left.\mathrm{CDCl}_{3}, \mathrm{ppm}\right)$ for Compound S18

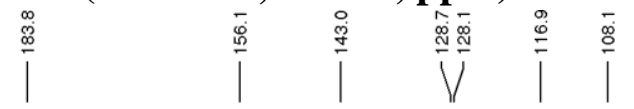<smiles>COc1cccc2c1C[C@H](C(=O)O)C2</smiles>

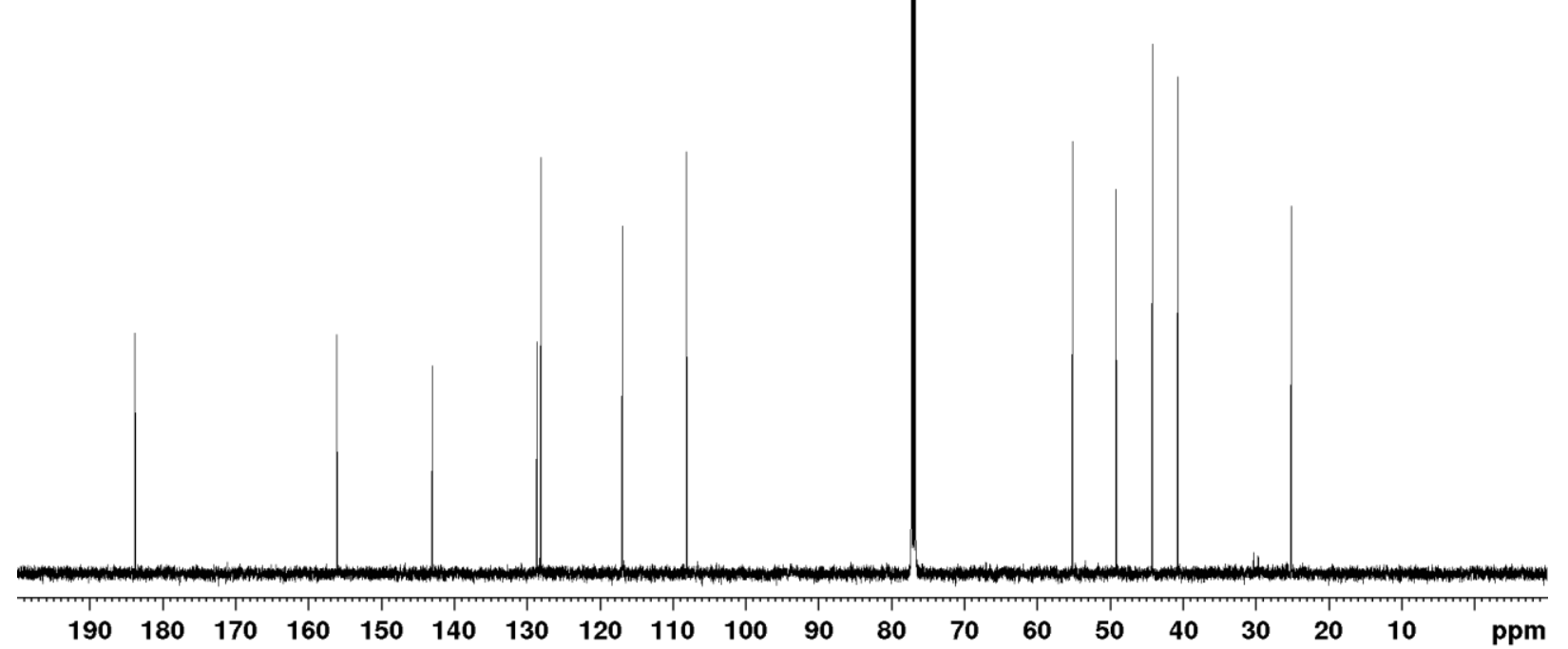

${ }^{1} \mathrm{H}$ NMR (500 MHz, CDCl3, ppm) for Compound S19

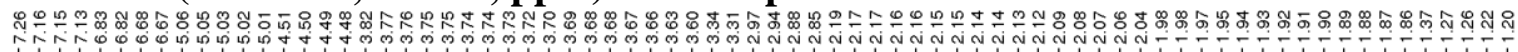<smiles>COc1cccc2c1C[C@@](C)(C(=O)N1CCC[C@H]1C(=O)OC(C)C)C2</smiles>

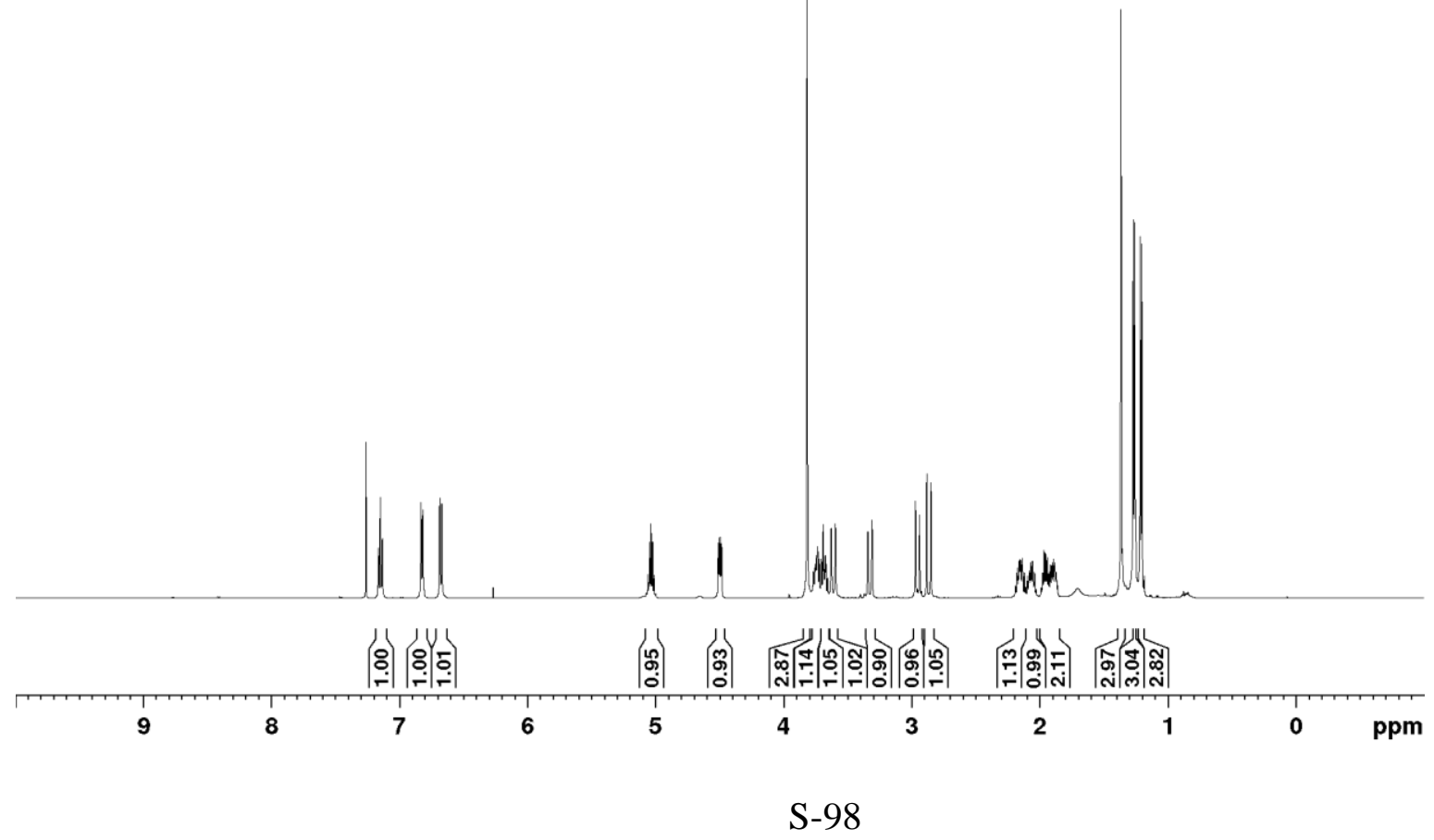


${ }^{13} \mathrm{C}$ NMR (126 MHz, $\mathrm{CDCl}_{3}$, ppm) for Compound S19

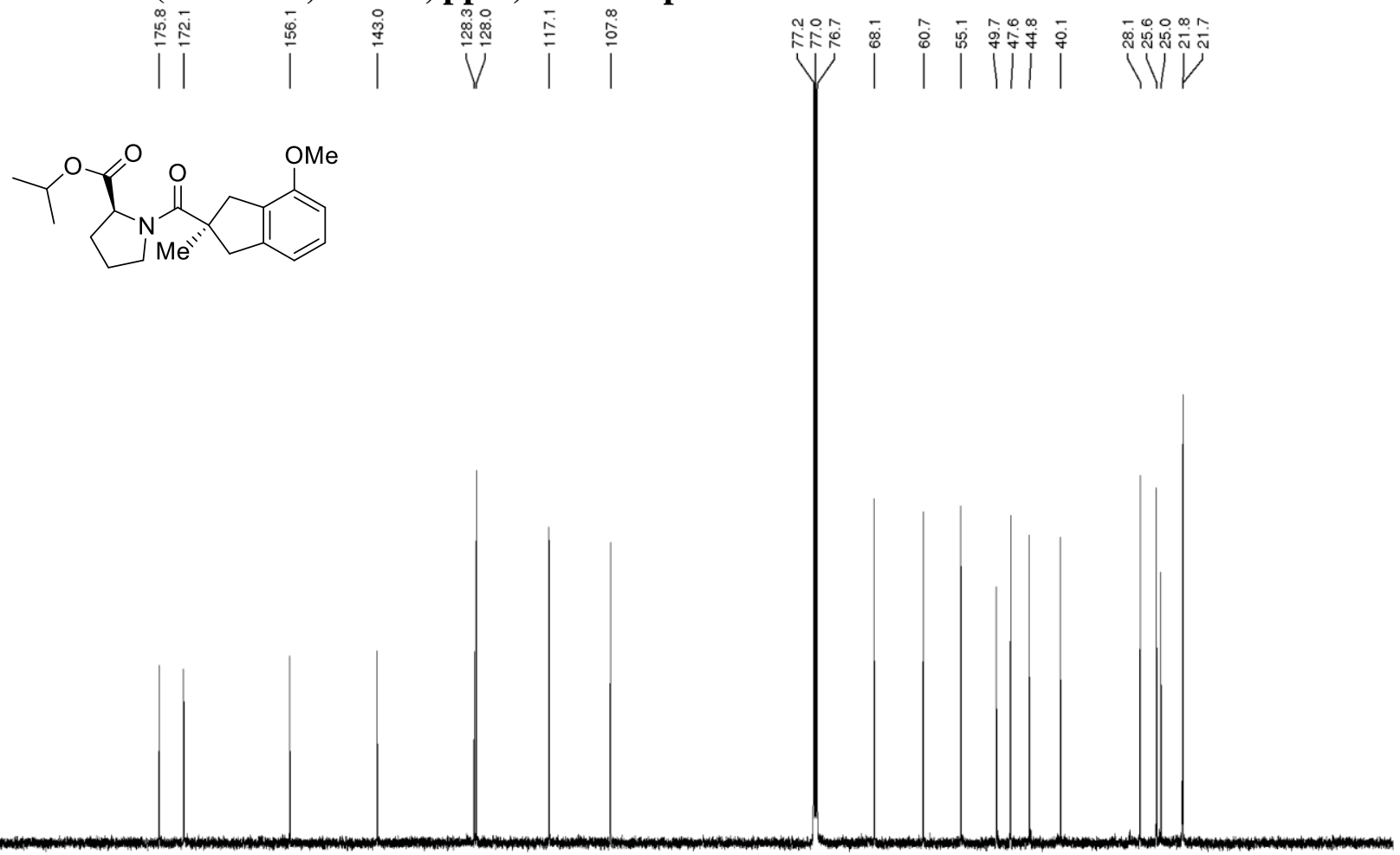

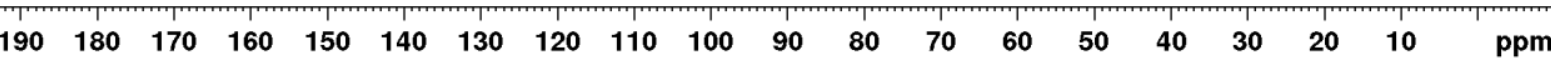

${ }^{1} \mathrm{H}$ NMR (500 MHz, CDCl3, ppm) for Compound S20

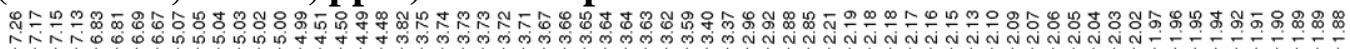

(2)<smiles>COc1cccc2c1C[C@H](C(=O)N1CCC[C@H]1C(=O)OC(C)C)C2</smiles>

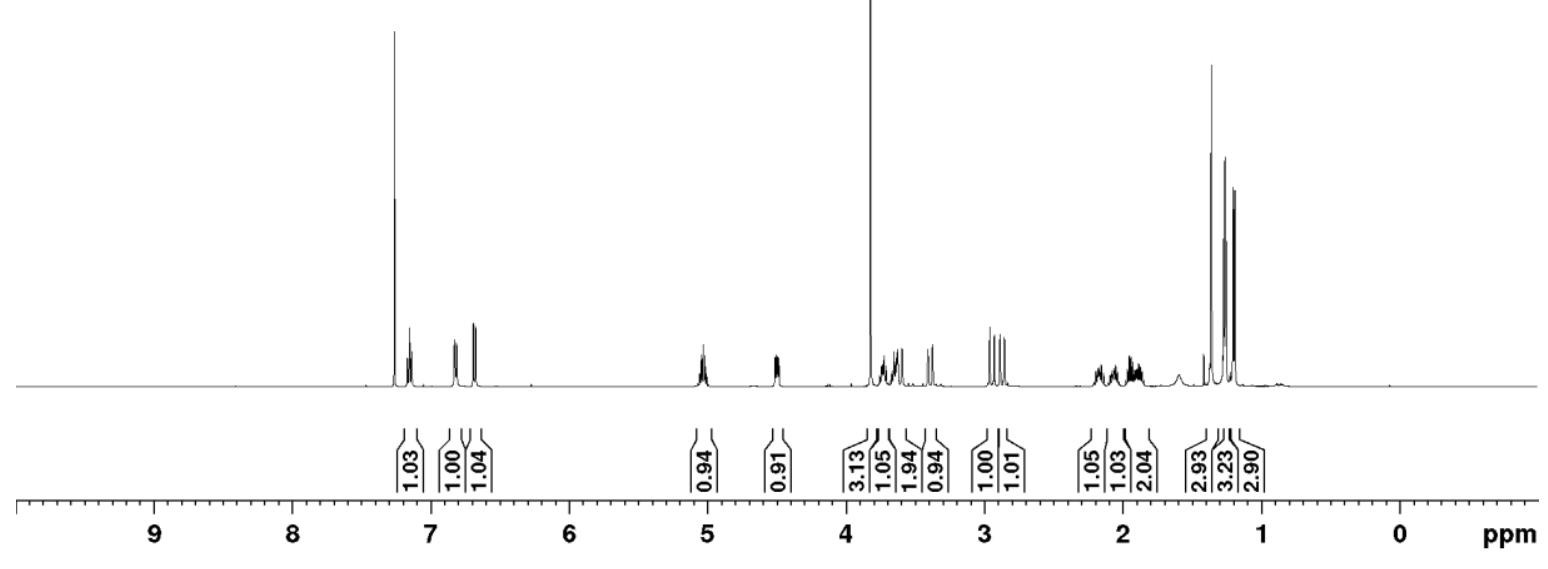

S-99 


\section{${ }^{13} \mathrm{C}$ NMR (126 MHz, $\left.\mathrm{CDCl}_{3}, \mathrm{ppm}\right)$ for Compound $\mathrm{S20}$}

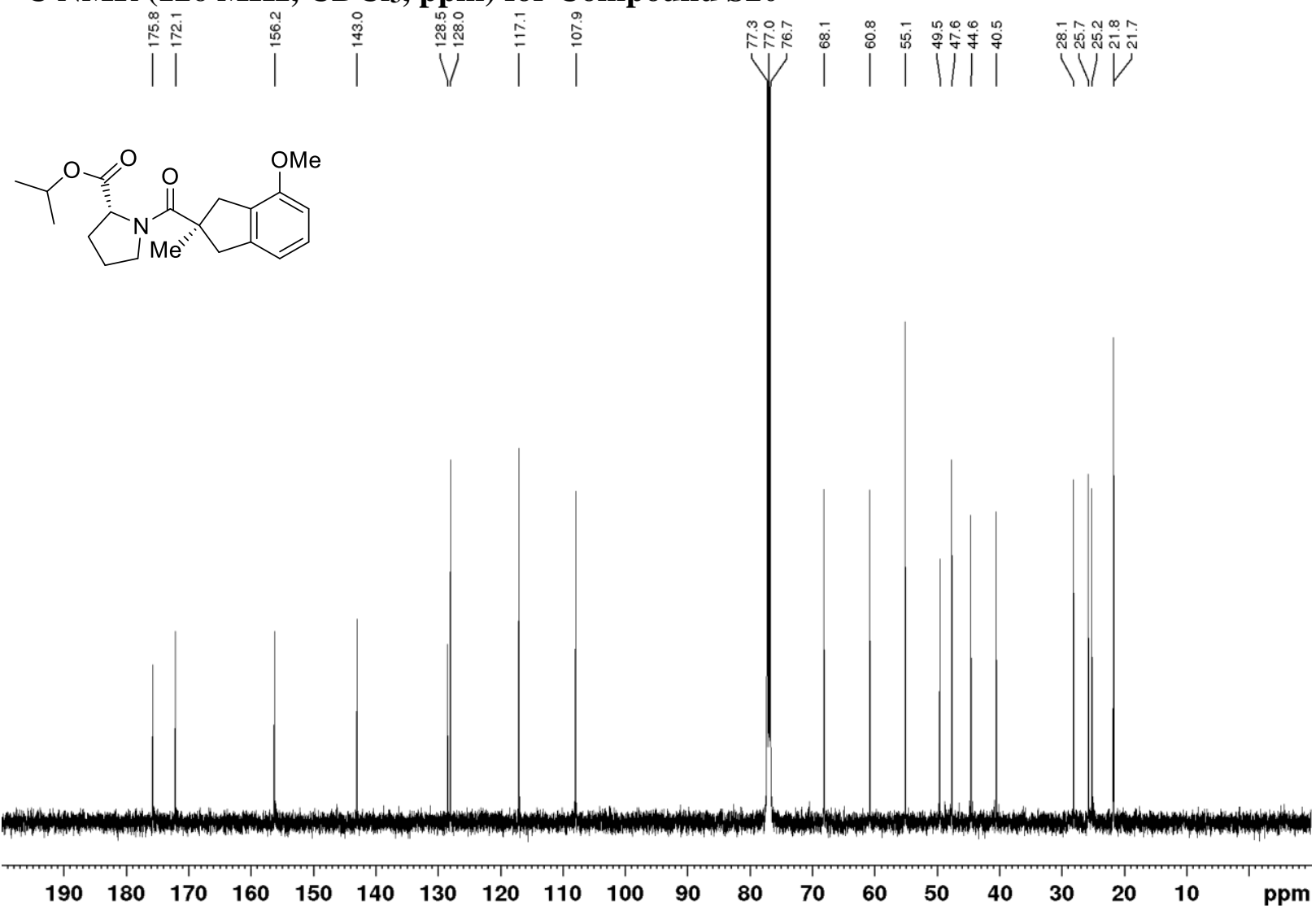


Figure 1. Expansion of key regions in the ${ }^{1} \mathrm{H}$ NMR spectra for compounds $\mathbf{2 4}$ and $\mathbf{S 1 6}$ (400, 500 $\left.\mathrm{MHz}, \mathrm{CDCl}_{3}, \mathrm{ppm}\right)$

A
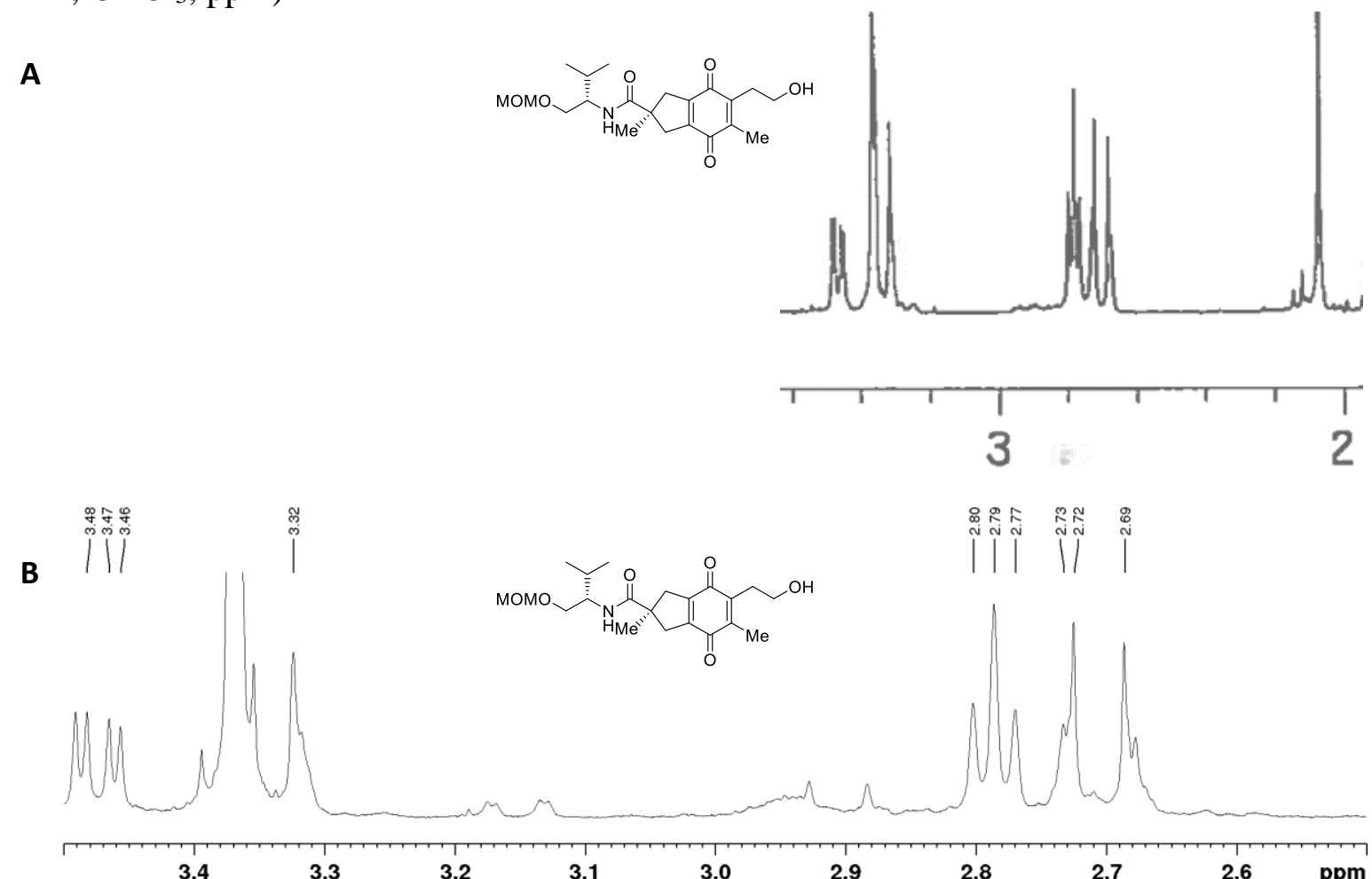

C
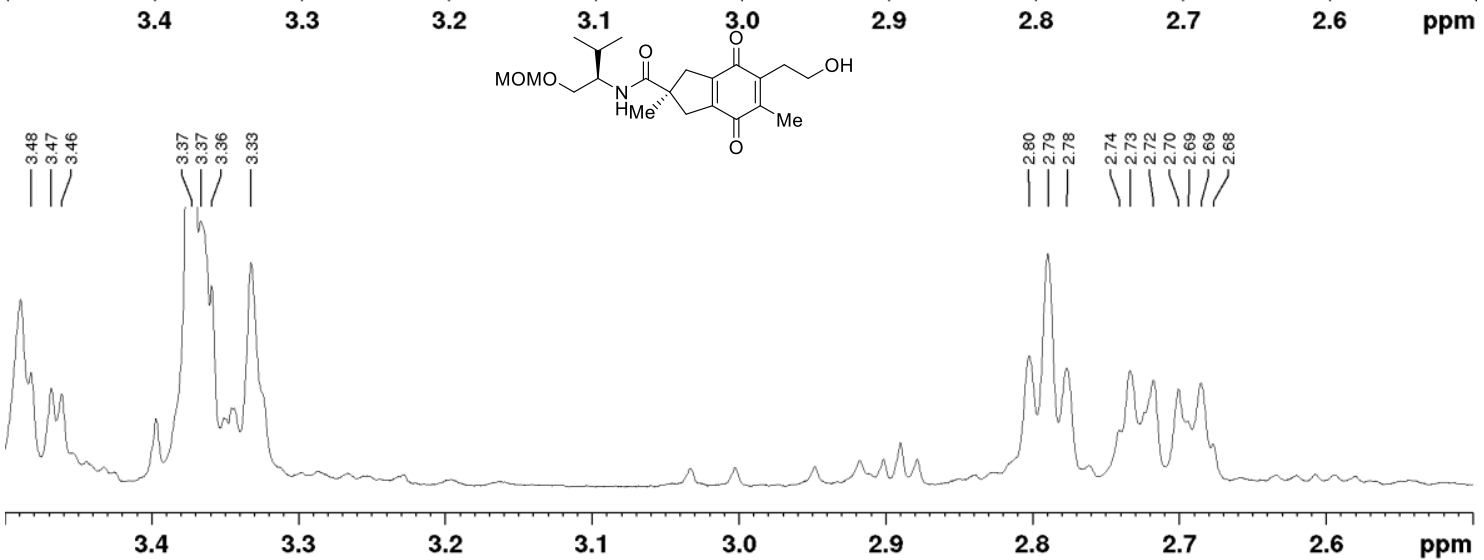
A) Authentic $\mathbf{2 4}^{20}$
B) 24 prepared from sulfone 6
C) Diastereomer of 24 (S16) prepared from sulfone 6 
Figure 2. Expansion of key regions in the ${ }^{13} \mathrm{C}$ NMR spectra for compounds $\mathbf{2 4}$ and $\mathbf{S 1 6}$ of (126 A $\left.\mathrm{MHz}, \mathrm{CDCl}_{3}, \mathrm{ppm}\right)$

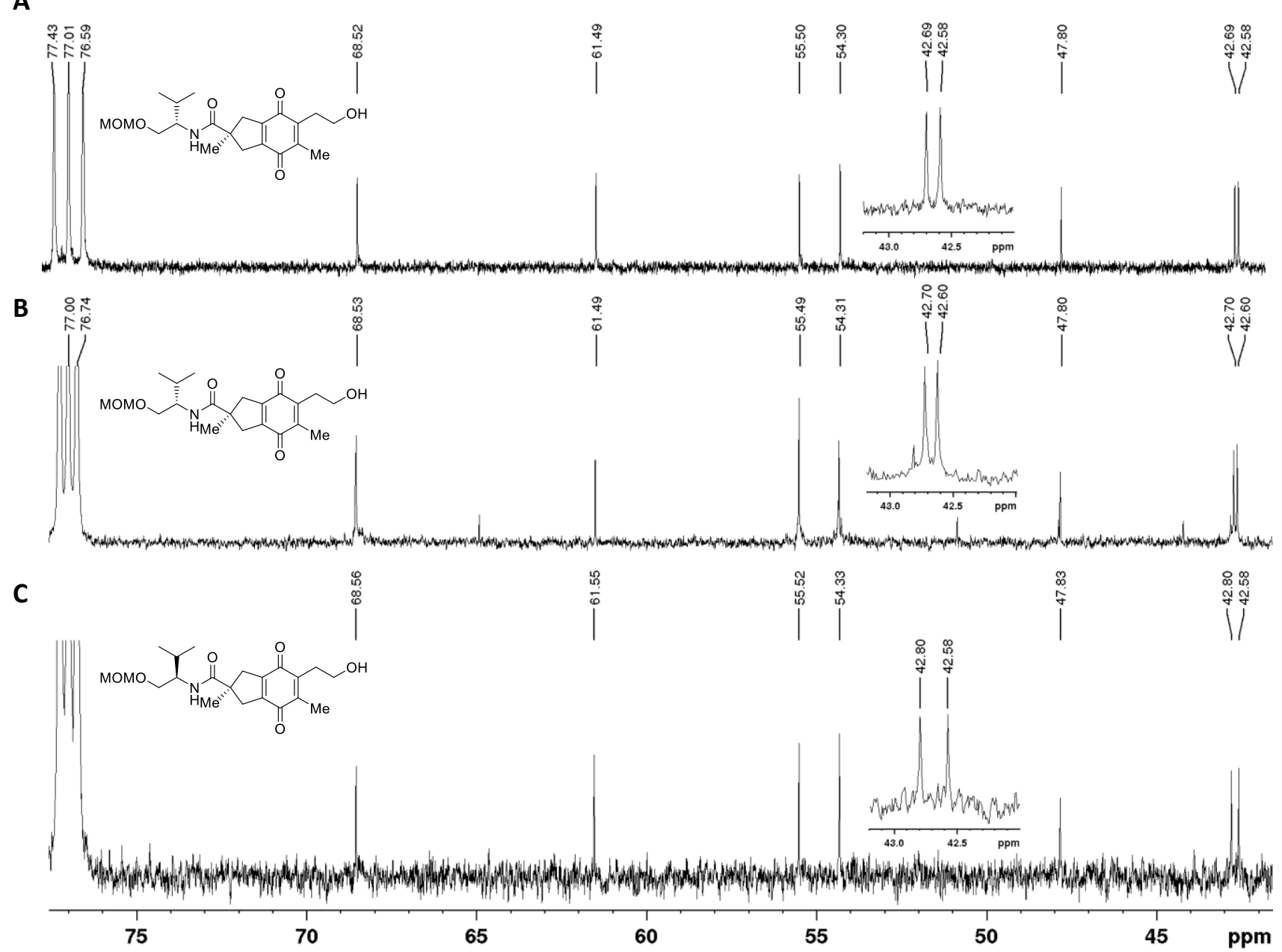
A) Authentic $\mathbf{2 4}^{20}$
B) 24 prepared from sulfone 6
C) Diastereomer of $\mathbf{2 4}$ (S16) prepared from sulfone 6 
Table 1. Comparison of (R)-puraqunionic acid (1) characterization data

\begin{tabular}{|c|c|c|}
\hline Method & Experimental Value & Literature Value $^{20 \mathrm{~b}}$ \\
\hline${ }^{1} \mathrm{H}$ NMR $500 \mathrm{MHz}, \mathrm{CDCl}_{3}(\mathrm{ppm})$ & $\begin{array}{c}3.77,2 \mathrm{H}, \mathrm{t}, J=6.4 \mathrm{~Hz} \\
3.39,2 \mathrm{H}, \mathrm{m} \\
2.80,2 \mathrm{H}, \mathrm{t}, J=6.4 \mathrm{~Hz} \\
2.76,2 \mathrm{H}, \mathrm{m} \\
2.08,3 \mathrm{H}, \mathrm{s} \\
1.43,3 \mathrm{H}, \mathrm{s}\end{array}$ & $\begin{array}{c}3.75,2 \mathrm{H}, \mathrm{t}, J=6.5 \mathrm{~Hz} \\
3.37,2 \mathrm{H}, \mathrm{m} \\
2.78,2 \mathrm{H}, \mathrm{t}, J=6.5 \mathrm{~Hz} \\
2.74,2 \mathrm{H}, \mathrm{m} \\
2.07,3 \mathrm{H}, \mathrm{s} \\
1.41,3 \mathrm{H}, \mathrm{s}\end{array}$ \\
\hline${ }^{13} \mathrm{C}$ NMR $500 \mathrm{MHz}, \mathrm{CDCl}_{3}(\mathrm{ppm})$ & $\begin{array}{c}186.2 \\
185.7 \\
180.0 \\
145.7 \\
145.3 \\
142.8 \\
141.4 \\
61.5 \\
46.7 \\
43.4 \\
42.3 \\
29.9 \\
25.7 \\
12.2\end{array}$ & $\begin{array}{c}186.2 \\
185.7 \\
181.5 \\
145.7 \\
145.4 \\
142.8 \\
141.4 \\
61.4 \\
46.9 \\
42.3 \\
42.3 \\
29.9 \\
25.7 \\
12.1\end{array}$ \\
\hline $\operatorname{IR}\left(\mathrm{cm}^{-1}\right)$ & $\begin{array}{c}3393,2968,1702,1647,1462 \\
1430,1376,1333,1276,1210 \\
1022,736\end{array}$ & $\begin{array}{c}3450,2965,1705,1650,1460 \\
1425,1375,1330,1285,1210 \\
1045,720\end{array}$ \\
\hline $\begin{array}{c}\text { HRMS }(\mathrm{m} / \mathrm{z}) \\
{\left[\mathrm{C}_{14} \mathrm{H}_{16} \mathrm{O}_{5} \mathrm{Na}^{+}=287.0890\right.} \\
{\left[\mathrm{C}_{14} \mathrm{H}_{16} \mathrm{O}_{5}\right]^{+}=\mathbf{2 6 4 . 0 9 9 8}}\end{array}$ & $287.0899\left[\mathrm{C}_{14} \mathrm{H}_{16} \mathrm{O}_{5} \mathrm{Na}\right]^{+}$ & $264.0999\left[\mathrm{C}_{14} \mathrm{H}_{16} \mathrm{O}_{5}\right]^{+}$ \\
\hline Optical Rotation & $+3.5[\alpha]_{\mathrm{D}}^{22}\left(c 0.5, \mathrm{CHCl}_{3}\right)$ & $+1[\alpha]_{\mathrm{D}}^{22}\left(c 1.0, \mathrm{CHCl}_{3}\right)$ \\
\hline Physical Appearance & yellowish oil & yellowish oil \\
\hline
\end{tabular}

\section{References:}

[1] R. R. Hill, S. D. Rychnovsky, The Journal of Organic Chemistry 2016, 81, 10707-10714.

[2] A. I. Meyers, D. A. Dickman, T. R. Bailey, Journal of the American Chemical Society 1985, 107, 7974-7978.

[3] A. Arpin, J. M. Manthorpe, J. L. Gleason, Organic Letters 2006, 8, 1359-1362.

[4] B. Bieszczad, M. Barbasiewicz, Chemistry - A European Journal 2015, 21, 10322-10325.

[5] D. E. Gingrich, J. G. Lisko, M. A. Curry, M. Cheng, M. Quail, L. Lu, W. Wan, M. S. Albom, T. S. Angeles, L. D. Aimone, R. C. Haltiwanger, K. Wells-Knecht, G. R. Ott, A. K. Ghose, M. A. Ator, B. Ruggeri, B. D. Dorsey, Journal of Medicinal Chemistry 2012, 55, 4580-4593.

[6] P. Dowd, W. Weber, The Journal of Organic Chemistry 1982, 47, 4774-4777.

[7] A. K. Singh, P. K. Khade, Tetrahedron Letters 2011, 52, 4899-4902.

[8] L. M. Tolbert, J. E. Haubrich, Journal of the American Chemical Society 1994, 116, 1059310600.

[9] F. J. Williams, H. M. Relles, J. S. Manello, P. E. Donahue, The Journal of Organic Chemistry 1977, 42, 3419-3425.

[10] C. Su, Y. Ye, L. Xu, C. Zhang, Macromolecular Chemistry and Physics 2011, 212, 2487-2492.

[11] J. Heiszman, I. Bitter, K. Harsányi, L. Töke, Synthesis 1987, 1987, 738-739. 
[12] D. A. White, Synthetic Communications 1977, 7, 559-568.

[13] J. A. Donnelly, J. R. Keegan, Monatshefte Fur Chemie 1982, 113, 209-212.

[14] J. Velcicky, U. Bodendorf, P. Rigollier, R. Epple, D. R. Beisner, D. Guerini, P. Smith, B. Liu, R. Feifel, P. Wipfli, R. Aichholz, P. Couttet, I. Dix, T. Widmer, B. Wen, T. Brandl, Journal of Medicinal Chemistry 2018, 61, 865-880.

[15] P. A. Wade, P. A. Kondracki, The Journal of Organic Chemistry 1993, 58, 3140-3147.

[16] J. M. Hoover, S. S. Stahl, Journal of the American Chemical Society 2011, 133, 16901-16910.

[17] E. Szymańska, K. Frydenvang, A. Contreras-Sanz, D. S. Pickering, E. Frola, Z. Serafimoska, B. Nielsen, J. S. Kastrup, T. N. Johansen, Journal of Medicinal Chemistry 2011, 54, 7289-7298.

[18] S. Vuoti, J. Autio, M. Laitila, M. Haukka, J. Pursiainen, European Journal of Inorganic Chemistry 2008, 2008, 397-407.

[19] S. P. Cooper, K. I. Booker-Milburn, Angewandte Chemie International Edition 2015, 54, 64966500.

[20] a) E. A. Tiong, D. Rivalti, B. M. Williams, J. L. Gleason, Angewandte Chemie International Edition 2013, 52, 3442-3445; b) U. Becker, G. Erkel, T. Anke, O. Sterner, Natural Product Letters 1997, 9, 229-236.

[21] R. Melot, M. V. Craveiro, T. Bürgi, O. Baudoin, Organic Letters 2019, 21, 812-815.

[22] M. Todorovic, K.D. Schwab, J. Zeisler. C. Zhang, F. Bénard. David M. Perrin, Angewandte Chemie International Edition 2019, 58, 14120-12124. 